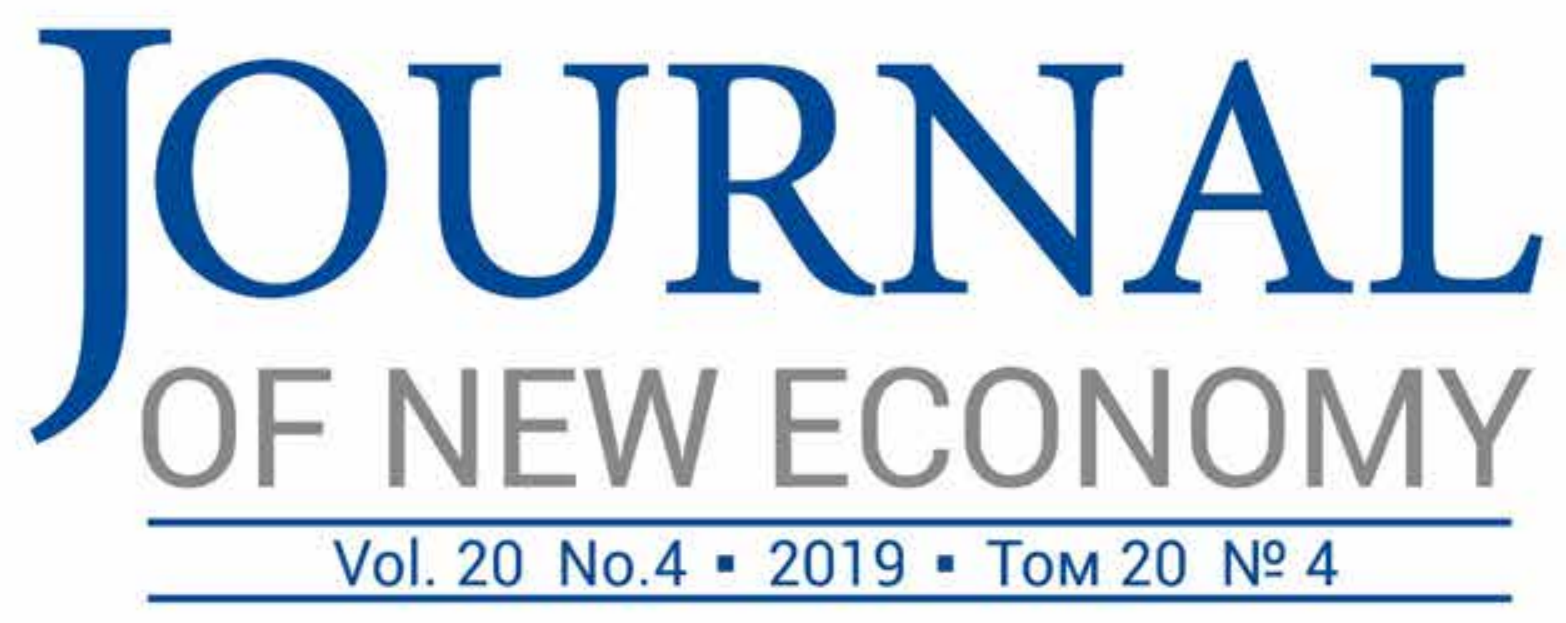

Трансформационные процессы в экономике

Transformation Processes in Economy

Региональные аспекты экономического роста Regional Aspects of Economic Growth

Развитие отраслевых рынков и предприятий

Development of Industrial Markets and Enterprises

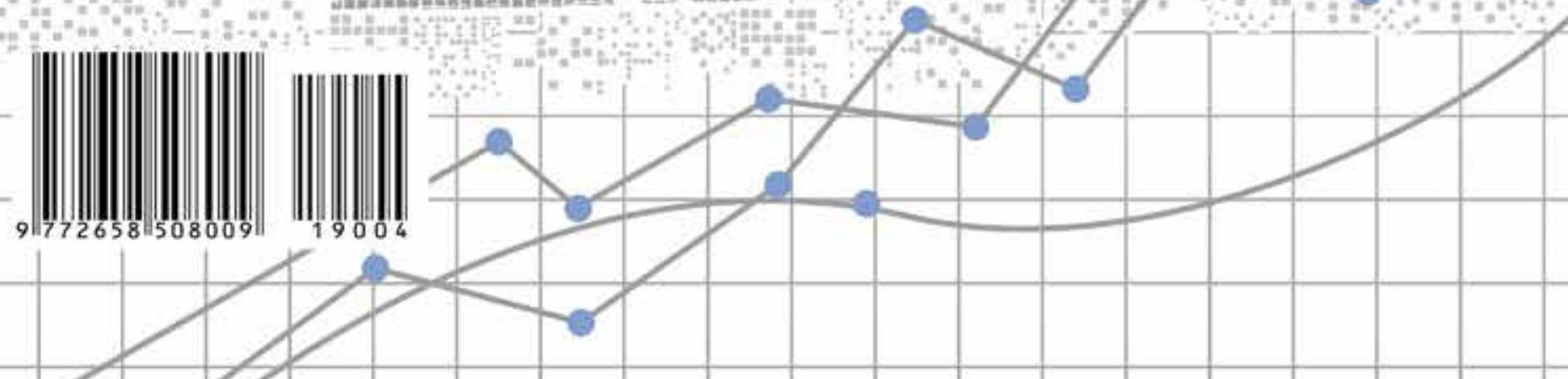


Область непознанного, неведомого значительно обширнее суммы накопленных человечеством знаний. Академик В. И. Вернадский

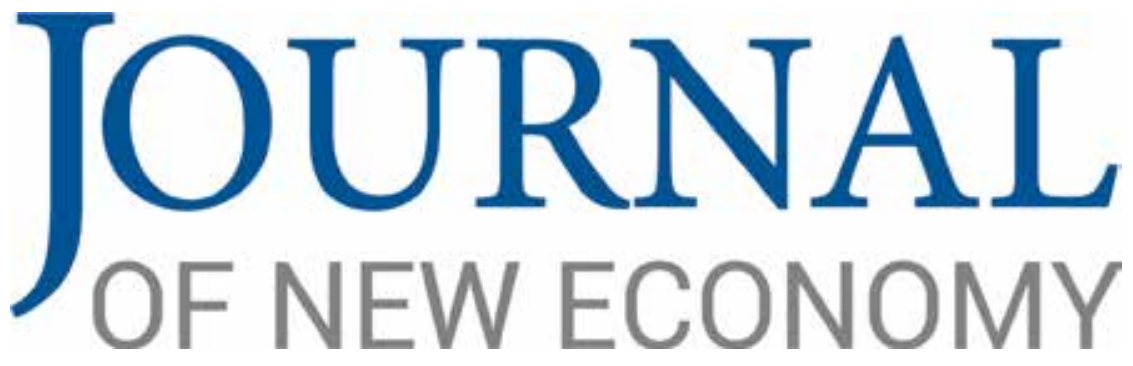

$\begin{array}{lll}\text { T. } 20, \text { № } 4 & 2019 & \text { Vol. 20, No. } 4\end{array}$ 


\section{Journal of New Economy}

\section{Редакционная коллегия}

\section{Главный редактор}

Я. П. Силин, д-р экон. наук (Екатеринбург, Россия)

\section{Заместители главного редактора}

Е. Г. Анимица, д-р геогр. наук, профессор (Екатеринбург, Россия)

В. П. Иваницкий, д-р экон. наук, профессор (Екатеринбург, Россия)

\section{Члены редколлегии}

С. Д. Бодрунов, д-р экон. наук, профессор

(Москва, Россия)

В. С. Бочко, д-р экон. наук, профессор

(Екатеринбург, Россия)

Е. Б. Дворядкина, д-р экон. наук, профессор

(Екатеринбург, Россия)

М. С. Марамыгин, д-р экон. наук, профессор (Екатеринбург, Россия)

Р. М. Нижегородцев, д-р экон. наук

(Москва, Россия)

Е. В. Попов, чл.-кор. РАН, д-р экон. наук, д-р физ.-мат. наук, профессор

(Екатеринбург, Россия)

К. К. Рихтер, д-р физ.-мат. наук, профессор

(Санкт-Петербург, Россия)

\section{Члены международного совета}

И. Браде, $\mathrm{PhD}$ (Германия)

Г. Карл, $\mathrm{PhD}$, профессор (Германия)

э. М. Сандоян, д-р экон. наук, профессор (Армения)

Дж. Стракова, $\mathrm{PhD}$ (Чехия)

В. Стрелковский, $\mathrm{PhD}$, профессор (Чехия)

В. Н. Шимов, д-р экон. наук, профессор (Белоруссия)

\section{Editorial Board}

Chief Editor

Ya. P. Silin, Dr. Sc. (Economics) (Ekaterinburg, Russia)

\section{Deputy Chief Editors}

E. G. Animitsa, Dr. Sc. (Geography), Professor (Ekaterinburg, Russia)

V. P. Ivanitsky, Dr. Sc. (Economics), Professor (Ekaterinburg, Russia)

\section{Editorial Team}

S. D. Bodrunov, Dr. Sc. (Economics), Professor (Moscow, Russia)

V. S. Bochko, Dr. Sc. (Economics), Professor (Ekaterinburg, Russia)

E. B. Dvoryadkina, Dr. Sc. (Economics), Professor (Ekaterinburg, Russia)

M. S. Maramygin, Dr. Sc. (Economics), Professor (Ekaterinburg, Russia)

R. M. Nizhegorodtsev, Dr. Sc. (Economics)

(Moscow, Russia)

E.V. Popov, Dr. Sc. (Economics), corresponding member of RAS, Dr. Sc. (Physics \& Mathematics), Professor (Ekaterinburg, Russia)

K. K. Richter, Dr. Sc. (Physics \& Mathematics), Professor (Saint Petersburg, Russia)

Members of International Council

I. Brade, $\mathrm{PhD}$ (Germany)

H. Karl, PhD, Professor (Germany)

E. M. Sandoyan, Dr. Sc. (Economics), Professor (Armenia)

J. Strakova, $\mathrm{PhD}$ (the Czech Republic)

W. Strielkowski, PhD, Professor (the Czech Republic)

V. N. Shimov, Dr. Sc. (Economics), Professor (Belarus)

Учредитель: ФГБОУ ВО «Уральский государственный экономический университет»

До 18 апреля 2019 г. журнал «Journal of New Economy» выходил под названием «Известия Уральского государственного экономического университета» (ISSN 2073-1019, номер в перечне рецензируемых научных изданий, в которых должны быть опубликованы основные результаты диссертаций на соискание ученой степени кандидата наук, на соискание ученой степени доктора наук - № 667 от 03.04.2019)

$$
\begin{gathered}
\text { Включен в Российский индекс научного цитирования } \\
\text { (импакт-фактор журнала на дату подписания в печать 1,116) } \\
\text { Основан в } 1999 \text { г. }
\end{gathered}
$$

Зарегистрирован Федеральной службой по надзору в сфере связи, информационных технологий и массовых коммуникаций Свидетельство о регистрации средства массовой информации ПИ № ФС77-75630 от 19 апреля 2019 г.

Подписной индекс Агентства Роспечати: 72059 Цена свободная 


\section{Journal of New Economy}

T. 20, № $42019 \quad$ Vol. 20, No. 4

\section{Содержание}

\section{ТРАНСФОРМАЦИОННЫЕ ПРОЦЕССЫ В ЭКОНОМИКЕ}

Черняков М. К., Чернякова М. М. Прогнозирование тенденций развития цифрового правительства (e-government) в постсоветских странах . . . . . . . . . . . . .

РЕГИОНАЛЬНЫЕ АСПЕКТЫ ЭКОНОМИЧЕСКОГО РОСТА

Юдина М. А. Методические аспекты диагностики макрорегиональных структурных сдвигов . . . . . . . . . . . . . . . . . . . . . .

Дворядкина Е. Б., Простова Д. М. Некоммерческие организации в региональной экономике: теоретический подход к исследованию . . . . . . . . . . .

Бенц Д. С. Моделирование эколого-экономической эффективности Уральского

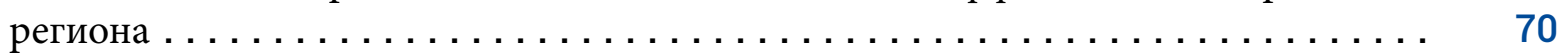

\section{РАЗВИТИЕ ОТРАСЛЕВЫХ РЫНКОВ И ПРЕДПРИЯТИЙ}

Мисюра А. В. Высокотехнологичное промышленное предприятие: нормативный

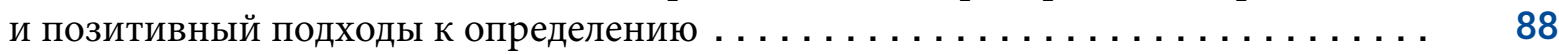

Feng A. Q. The shale revolution and Sino-Russian energy cooperation . . . . . . . 108

Koksharov V. A., Dzhamanbalin B. K. Strategic assessment of electric power industry development: A case of Kazakhstan. . . . . . . . . . . . . . . . . . . .

Требования к материалам, представляемым в журнал . . . . . . . . . . . . . . . 133 


\title{
Journal of New Economy
}

\author{
$\begin{array}{lll}\text { T. } 20 \text {, № } 4 & \text { Vol. 20, No. } 4\end{array}$
}

\section{Contents}

\section{TRANSFORMATION PROCESSES IN ECONOMY}

Chernyakov M. K., Chernyakova M. M. Forecasting trends in e-government development

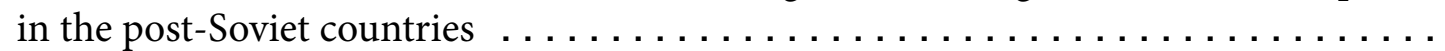

\section{REGIONAL ASPECTS OF ECONOMIC GROWTH}

Yudina M. A. Methodological aspects of detecting macroregional structural shifts . ...

Dvoryadkina E. B., Prostova D. M. Nonprofit organisations in the regional economy: A theoretical approach to the research $\ldots \ldots \ldots \ldots \ldots \ldots \ldots \ldots \ldots \ldots \ldots$

Benz D. S. Modelling of environmental and economic efficiency: A case of the Ural

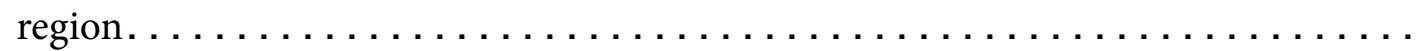

\section{DEVELOPMENT OF INDUSTRIAL MARKETS AND ENTERPRISES}

Misyura A. V. High-tech industrial company: A normative and a positive approach

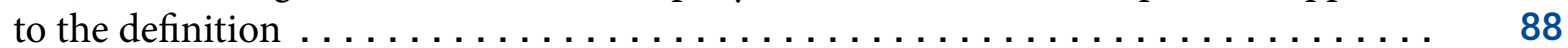

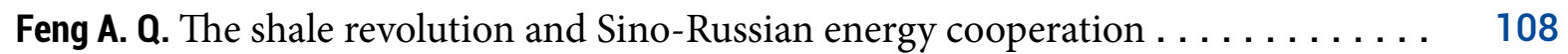

Koksharov V. A., Dzhamanbalin B. K. Strategic assessment of electric power industry development: A case of Kazakhstan. . . . . . . . . . . . . . . . . . . 
М. К. Черняков Новосибирский государственный технический университет, г. Новосибирск, Российская Федерация

M. М. Чернякова Сибирский институт управления - филиал Российской академии народного хозяйства и государственной службы при Президенте РФ, г. Новосибирск, Российская Федерация

\title{
Прогнозирование тенденций развития цифрового правительства (e-government) в постсоветских странах
}

\begin{abstract}
Аннотащия. Цифровые технологии становятся движущей силой для инноваций и экономического роста, но вместе с тем вызывают множество проблем. Одной из них является неравномерность формирования цифровой экономики в постсоветских странах. В основу исследования была положена методология системного, комплексного и территориального подходов с использованием методов экономической интерпретации полученных результатов - функционального и сравнительного анализа. Научная новизна работы состоит в кластеризации постсоветских стран по критерию уровня развития в них цифровой экономики. Анализ степени готовности экономик бывших советских республик к трансформации в цифровую экономику показал три уровня их готовности: средний (EGDI от 0,25 до 0,5), высокий (EGDI от 0,5 до 0,75) и очень высокий (EGDI>0,75). В результате ранжирования в кластер с очень высоким уровнем развития цифровизации вошли пять стран северо-западной, с высоким - восемь стран юго-западной, средним две страны юго-восточной части постсоветского пространства. Основными вызовами при трансформации в цифровую экономику являются общая напряженная экономическая ситуация и задержка реализации мер по сокращению цифрового разрыва, которые привели к снижению темпов роста телекоммуникационных показателей стран бывшего СССР. Установлено, что важнейшей задачей для этих государств является разработка сбалансированных способов преодоления вызовов, что может максимизировать положительные эффекты и минимизировать риски цифровой экономики.
\end{abstract}

Ключевые слова: прогнозирование; тенденции; цифровая экономика; индекс развития; рейтинг; электронное правительство; управление.

Благодарности: Статья подготовлена при финансовой поддержке Новосибирского государственного технического университета (проект С19-12).

Для изитирования: Черняков М. К., Чернякова М. М. Прогнозирование тенденций развития цифрового правительства (e-government) в постсоветских странах // Journal of New Economy. 2019. T. 20, № 4. C. 5-21. DOI: 10.29141/2073-1019-2019-20-4-1

Дата поступления: 29 апреля 2019 г.

\section{Введение}

Rажнейшей задачей для большинства стран мира является внедрение и совершенВ ствование информационно-коммуникационных технологий (ИКТ) для развития экономической и социальной сфер жизнедеятельности общества [Alkhatri et al., 2016, p. 173]. Все экономически развитые страны перешли к этапу доминирования сферы услуг на базе ИКТ, а население стало обществом информационного потребления. 
Впоследствии произошел гипертрофированный отрыв сферы компьютеризованных услуг от производства, что, однако, значительно упростило механизм большей части их получения. Стремительная монетизация Интернета сдвинула научно-техническую революцию с информационного на цифровой вектор. Довольно обособленные ИКТ теперь пропитывают все остальные революционные технологии, став «смазкой» для NBIC-конвергенции (Nano, Bio, Info, Cogno), необратимо меняющей жизнь человечества в направлении цифровой экономики (ЦЭ).

Исследование Е. Ф. Каббара [Kabbar, 2018, p. 5107] показывает сильную положительную корреляцию между электронным правительством 2005 г. и 2016 г. Это свидетельствует о том, что в общем рейтинге стран произошли незначительные изменения. Кроме того, результаты кластерного анализа выявили три отдельные группы стран/сегментов - лидеры, отстающие и среднеразвитые, а также что в период 2005-2016 гг. в кластерах было мало изменений. Это указывает на то, что страны, которые были высоко оценены в 2005 г., по-прежнему лидируют в 2016 г., а страны, которые были аутсайдерами в 2005 г., все еще остаются ими. Анализ группы стран постсоветского пространства, которые представляют особый интерес с точки зрания трансформации их экономики в цифровую, у Е. Ф. Каббара отсутствует.

В работе Н. А. Гвилия, А. В. Парфёнова, Т. Г. Шульженко [2019, с. 40] отражена эффективность управления интегрированными межкорпоративными логистическими системами в условиях цифровой экономики отдельных постсоветских стран. Однако источники информации по-прежнему требуют дальнейших количественных эмпирических исследований для обоснования развития цифровой экономики. Необходим такой обзор информационных источников, который упорядочивает соответствующие знания и обеспечивает прочную основу для будущих исследований. Имеющиеся метаанализы не дают конкретных результатов для надлежащего решения проблемы нехватки количественных эмпирических исследований в области электронного государственного управления [Wirtz, Daiser, 2018, p. 144].

Целью исследования является сравнительный анализ процесса цифровизации на территории республик бывшего Советского Союза с определением места России в нем, а также выявление проблем и перспектив развития цифровой экономики.

Для достижения поставленной цели необходимо решить следующие задачи:

- провести априорный анализ информации о состоянии развития цифрового правительства (e-government) в различных странах;

- обосновать методы и подходы для оценки и прогнозирования положения стран в области развития цифрового правительства;

- оценить положение Российской Федерации и других постсоветских стран в рейтинге электронного правительства ООН;

- спрогнозировать тенденции цифровизации в постсоветских странах.

\section{Теоретический обзор}

В последние десятилетия произошли беспрецедентные преобразования во всех секторах общества, вызванные стремительным развитием информационно-коммуникационных технологий. Это породило надежды на лучшую жизнь, как в развивающихся, так и в развитых странах. Благодаря революциям в области электронного бизнеса Правительства всех стран начали применять цифровые технологии в работе органов государственного управления, открывая веб-сайты для повышения эффективности предоставления государственных услуг. Исследование С. Ли-Гейлер и Т. Ли [Lee-Geiller, Lee, 2019, p. 208] вносит вклад в научную литературу, расширяя сферу анализа веб-сайтов электронного 
правительства за пределы вопроса о принятии граждан к вопросу об их участии и привнося взгляд на граждан как на активных агентов в управлении. Это обеспечивает целостную модель веб-сайтов государственных органов, что содействует демократическому электронному управлению.

Для одних стран формирование ЦЭ - это прогресс, для других - тенденции, включающие риски глобальных катастроф, для третьих - неизбежность, ускоряющая развитие. США, Канада, Япония, Германия продвигают ЦЭ в качестве стратегической цели на ближайшие десятилетия.

Использование и совершенствование ИКТ для повышения качества услуг государственного сектора (электронное правительство) признано важной задачей правительствами развитых стран. Несколько стран упорно работают над повышением рейтинга электронного правительства для своего устойчивого развития. В исследовании H. С. Алькатри и др. [Alkhatri et al., 2016, p. 173] были использованы несколько методов интеллектуального анализа данных для построения моделей, которые могут адекватно прогнозировать ранги электронного правительства 192 стран Организации Объединенных Наций и определять факторы, на них влияющие. Их анализ показывает, что атрибуты ООН, примененные для ранжирования стран, хорошо концептуализированы. Следовательно, можно точно предсказать результаты ранжирования с помощью классификации и регрессионного анализа. Ученые показывают, что индекс электронного правительства и телекоммуникационной инфраструктуры, фиксированная телефонная подписка, использование Интернета, человеческий капитал и индекс онлайн-услуг являются наиболее важными факторами в рейтинге электронного правительства.

Инновации в области телекоммуникаций и технологий обработки информации влияют на оказание государственных услуг. Одним из главных приоритетов правительств является достижение большей эффективности предоставления государственных услуг, а электронное правительство является одной из нескольких реализуемых мер. Ряд исследований подтверждают значительную взаимосвязь между уровнем развития электронного правительства и эффективностью предоставления государственных услуг как в целом, так и по функциям [Moreno-Enguix, Lorente Bayona, Gras-Gil, 2019, p. 122].

Нами с этой целью использованы различные модели расчета эффективности предоставления государственных услуг и функций. Эмпирический анализ, включающий корреляцию и множественные линейные регрессии, проводился в 2012-2014 гг. для одного сечения 35 экономик. Выявлена значительная взаимосвязь между электронным правительством и эффективностью, а также между онлайн-услугами, телекоммуникационной инфраструктурой и человеческим капиталом с эффективностью предоставления государственных услуг.

Всеобъемлющее развитие цифровых технологий становится движущей силой для инноваций и экономического роста в мире. Необходима оценка эффективности использования передового опыта правительств в интересах социального прогресса, особенно в странах с низким и средним уровнем развития [Choi, Park, 2019, p. 111], к которым относятся большинство стран постсоветского пространства.

Желаемый потенциал электронного правительства и его недостатки являются ключевыми причинами того, почему электронное правительство стало главной темой для ученых и практических работников. Происходит непрерывная трансформация цифрового правительства, идет поиск инновационных цифровых решений для повышения эффективности социального, экономического, политического и других видов управления. Понимание и прогнозирование таких изменений важно для политиков, правительственных 
чиновников, исследователей и всех, кто готовит, принимает, реализует или оценивает решения цифрового правительства [Janowski, 2015, p. 145].

Анализу концептуальной модели факторов, влияющих на состояние цифровой экономики, посвятили свое исследование А. П. Суходолов, Н. А. Слободняк, В. А. Маренко, $[2019$, с. 13,120$]$. Авторская когнитивная модель факторов, воздействующих на состояние цифровой экономики, применима для аналитического прогнозирования поведения и свойств исследуемой системы [Суходолов, Слободняк, Маренко, 2019, с. 120].

В статье О. Филатовой и др. [Filatova et al., 2017, р. 221] представлены результаты исследования электронного участия государств - членов Евразийского экономического союза. Полученные данные позволяют ранжировать страны по уровню электронного участия и предложить рекомендации по дальнейшему совершенствованию взаимодействия с общественностью.

В работе Т. Д. Нам [Nam, 2019, p. 120] рассматривается влияние зрелости электронного правительства на эффективность и результативность государственного управления с межстрановой точки зрения. С этой целью используется двухэтапная регрессия наименьших квадратов с учетом эндогенности электронного правительства. Регрессионный анализ глобальных критериев показал, что электронное правительство не может существенно повысить эффективность государственного управления. Политические, экономические и культурные различия между странами по-разному воздействуют на работу электронного правительства. Уровень демократии имеет криволинейную связь с эффективностью правительства. Таким образом, по результатам исследования идентифицированы недемократичные страны с хорошо функционирующими правительствами [Nam, 2019].

Качественная оценка четырех постсоветских стран указывает на принципиальные различия того, как электронное правительство используется для легитимного авторитаризма [Maerz, 2016, p. 727]. В то время как внеконкурентные режимы Туркменистана и Узбекистана создают свои веб-присутствия в первую очередь для международной аудитории, в конкурентных режимах Казахстана и России электронные правительства находят удивительную поддержку граждан этих стран на сайтах. В статье предлагается новая концепция электронного правительства в автократиях, которая иллюстрирует, как некоторые типы конкурентных авторитарных режимов используют свои веб-сайты не только для получения внешней легитимности, но и в качестве эффективного инструмента поддержки своего народа, предлагая онлайн-услуги и имитируя прозрачность и участие граждан в управлении.

Результаты исследований В. Э. Эбберса, М. Г. М. Янсена и А. Й. А. М. ван Дерсена [Ebbers, Jansen, van Deursen, 2016, p. 685] показали, что, компьютерная грамотность пользователей не способствует выбору онлайн-канала. Тем не менее авторы предсказывают высокую степень удовлетворения более квалифицированных в цифровом отношении пользователей, которые активней пользуются онлайн-услугами. Характер взаимодействия уровней компьютерной грамотности пользователей существенно коррелирует с выбором каналов.

Практическая значимость работы М. Кассена [Kassen, 2019, p. 301] заключается в том, что в ней дается глубокий анализ политики электронного правительства в Казахстане, который может быть полезен для оценки, изучения и реализации проектов государственного сектора, ориентированных на технологии особенно с точки зрения регулирования. Учитывая, что Казахстан является не только типичной развивающейся экономикой, но и переходным постсоветским обществом, имеющим уникальные политические и социально-экономические особенности управления, результаты исследований не удалось обобщить и экстраполировать на все развивающиеся страны. 
Круг их был уменьшен до весьма ограниченного числа аналогичных государств Восточной Европы, Кавказа и Центральной Азии.

\section{Методы исследования}

Методической базой исследования являются системный и сравнительный анализ, анализ причинно-следственных связей, наблюдение, сравнение и группировка данных, а также индуктивный и дедуктивный методы научного познания. Используемая информация взята из базы знаний электронного правительства $\mathrm{OOH}^{1}$, литературных источников и сети Интернет.

В основу исследований положены методы трендового и регрессионного анализа показателей развития цифровой экономики и Интернета [Lobova et al., 2018, p. 221]. Прогнозирование осуществлялось с применением потенциальной функции и методических подходов системного анализа, кибернетики, синергетики и многомерного статистического анализа с использованием цепей Маркова и Шаланова [Шаланов, 2008, с. 11]. В основном это нетрадиционные методы анализа, прогноза и управления нестационарными случайными процессами. Такой инструментарий позволяет глубже проникнуть в сущность тенденций формирования цифровых экономик, а также процессов их развития.

Для моделирования процесса Маркова необходимо иметь матрицу перехода $B$, которая называется также матрицей переходных вероятностей. Элементы этой матрицы $b_{i j}$ есть вероятности перехода $p_{i j}$ и отражают то обстоятельство, что объект, находящийся в момент времени $t$ в состоянии $i$, к моменту времени $t+\tau$ перейдет в состояние $j$, причем матрица перехода постоянна во времени, т. е.

$$
B(t+\tau)=B(t+s \tau, t+(s+1) \tau) .
$$

Если процесс развития системы представляет собой процесс Маркова, то при известном состоянии системы в момент времени $t_{0}$, которое представляется упорядоченным набором чисел $X\left(t_{0}\right)=\left(x_{1}^{0}, x_{2}^{0}, \ldots, x_{n}^{0}\right)$, можно спрогнозировать его состояние в момент $t>t_{0}$ периода прогноза $X\left(t_{0}\right)=\left(x_{1}^{1}, x_{2}^{1}, \ldots, x_{n}^{1}\right)$, причем за один временной шаг $\tau$, т. е. при $t=t_{0}+\tau$ :

$$
X(t)=B \times X\left(t_{0}\right)
$$

Цепью Маркова называют последовательность состояний процесса Маркова в момент времени прогнозного периода [Шаланов, 2008, с. 100]. Цепь Маркова не имеет широкого распространения, поскольку стационарные случайные процессы в природе встречаются не так часто. Процессу Маркова присущи те же условия, которые отражены в формуле Пуассона, и их принято считать математической моделью простейшего потока событий [Кельберт, Сухов, 2010]. Формулу применяют для определения вероятностей перехода в дискретном стационарном случайном процессе, в частности в марковском процессе. Эти формулы применяются для расчета вероятностей перехода с целью формирования переходной матрицы. Часто эти вероятности получают экспертным путем, что повышает влияние субъективного фактора (мнения эксперта).

Процессы Маркова широко применяются в теории массового обслуживания, поскольку потоки требований в этих системах представляют собой простейший поток событий. Таким образом, процесс Маркова имеет место, если поток событий является простейшим, или пуассоновским.

${ }^{1}$ UN E-Government Knowledgebase. (2018). URL: https://publicadministration.un.org/egovkb/en-us/Reports /UN-E-Government-Survey-2018 
Формулы Шаланова являются рекуррентными. Чтобы вычислить прогноз на последующий период, следует спрогнозировать состояние системы за предшествующий период, в отличие от цепей Маркова, где прогноз на последующий период не зависит от предыдущего состояния системы. Такой вид прогнозирования имеет обобщающую структуру, характеризуется нестационарным случайным процессом, называется процессом Шаланова и может быть представлен цепью «...Шаланова - последовательность состояний шалановского процесса в моменты времени прогнозного периода» [Шаланов, 2008, с. 107].

Как показали предварительные расчеты и проверка адекватности, математическое ожидание более точно рассчитывалось цепями Маркова, а рассеивание цепями Шаланова. Для получения лучших характеристик с целью расчета прогнозных параметров было предложено использовать сочетание цепей Маркова и Шаланова и такую цепь именовать цепью Унтуры-Черняковой [Степанов, 2017, с. 17]. Математическое ожидание определялось как среднеарифметическая величина математических ожиданий, рассчитанных цепями Маркова и Шаланова в пропорциях 3 к 1:

$$
\mathrm{M}_{\mathrm{yч}}=\frac{3 \times \mathrm{M}_{\mathrm{M}}+\mathrm{M}_{\mathrm{w}}}{4}
$$

а рассеивание - как среднегеометрическая величина рассеиваний, рассчитанных цепями Маркова и Шаланова в пропорциях 1 к 3:

$$
\sigma_{\mathrm{yч}}=\sqrt{\frac{\sigma_{\mathrm{M}}^{2}+3 \times \sigma_{\mathrm{w}}^{2}}{4}} .
$$

Зависимости (3) и (4) были получены в результате сравнительного анализа при разработке методики прогнозирования региональных и муниципальных бюджетов [Степанов, 2017, с. 17].

\section{Результаты исследования}

В контексте развития цифровой экономики как новой парадигмы социально-экономического прогресса страны особенно актуальны понимание российского феномена электронного (цифрового) взаимодействия государства и общества, а также теоретические исследования в рамках так называемого «движения за переосмысление власти» [Ерженин, 2018, с. 205]. Авторская позиция В. Д. Марковой [2018, с. 7] относительно направлений влияния цифровой экономики на деятельность компаний основана на анализе зарубежных исследований и российской практике цифровой трансформации. Автор показывает, что эти направления пока охватывают отдельные процессы и объекты бизнеса. Содержательный профиль публикаций в Российском научном сообществе прежде всего связан с социально-политическими вопросами электронного правительства, в отличие от публикаций в развитых странах, где модернизация процессов управления и эффективность использования технологий остаются наиболее острыми на протяжении десятилетия [Ерженин, 2018, с. 205].

В рейтинге ООН по развитию электронного правительства Россия в 2018 г. заняла 35-е место (рис. 1). Рейтинг электронного правительства (E-Government Development Index) $\mathrm{OOH} \mathrm{является} \mathrm{одним} \mathrm{из} \mathrm{ключевых} \mathrm{показателей} \mathrm{развития} \mathrm{информационного} \mathrm{общест-}$ ва в мире. Позиция стран определяется на основе их общего индекса [Whitmore, 2012, pp. 68-75]. Этот индекс-показатель учитывает три фактора:

- веб-присутствие органов государственной власти;

- телекоммуникационную инфраструктуру;

- человеческий капитал. 
Влияние ИКТ в сфере государственного управления приводит к быстрым и многократным преобразованиям, повышению роли оцифровки в процессе управления как генерирующего элемента общественной ценности [Todorut, Tselentis, 2018, p. 73].

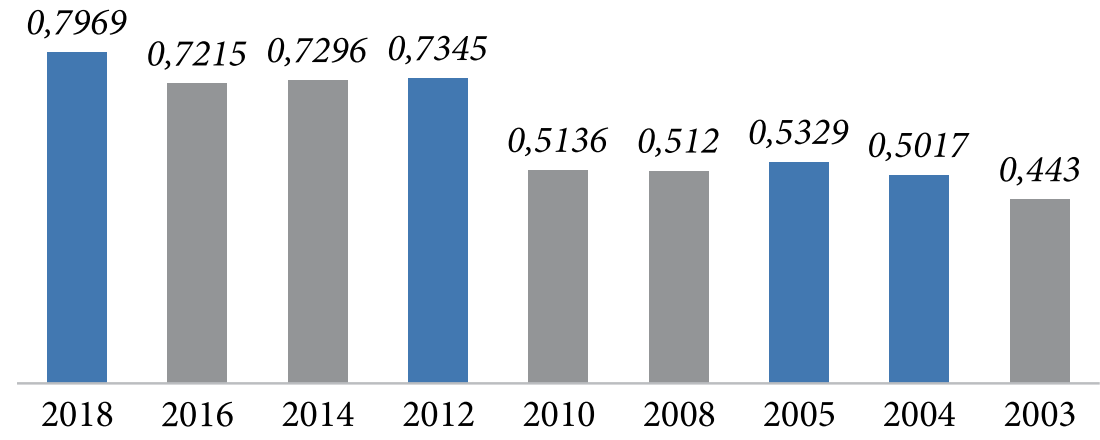

Рис. 1. Динамика формирования цифровой экономики в России по рейтингу электронного правительства $\mathrm{OOH}^{1}$

Fig. 1. Russia's digital economy dynamics according to the UN E-Government rating

Из рис. 1 следует, что положительная динамика роста уровня цифровизации в России прерывалась спадом, приходящимися на периоды кризисов 2008 и 2014 гг. После преодоления неблагоприятных внешних воздействий отмечался рост интенсивности использования ИКТ для предоставления услуг. Согласно данным индекса 2012 г., Россия вошла в третью десятку стран, заняв 27-е место (из 190) против 59-го места в исследовании 2010 г. В рейтинге 2012 г. Россия находилась между Монако и ОАЭ. Первую пятерку рейтинга 2012 г. занимали Корея, Нидерланды, Великобритания, Дания и США. Интересно, что резкое продвижение России вперед по ключевым показателям исследователи отмечают именно в период с 2010 по 2012 г.

Согласно данным рейтинга ООН за 2014 г., лидером осталась Корея, на втором месте Австралия, на третьем Сингапур. Россия расположилась на 27-м месте (позиция не изменилась относительно результатов 2012 г.). По итогам 2014 г. Россия оставила позади такие европейские страны бывшего Советского Союза, как Латвия и Литва, Казахстан разместился на 28-м месте.

По итогам 2016 г. Россия опустилась в рейтинге на 35-е место с 27-го в 2014 г. Падение связано с динамикой двух индексов - индекса телекоммуникаций и индекса онлайновых услуг. Они вместе с индексом человеческого капитала формируют с одинаковыми весами композитный индекс развития электронного правительства, на основе которого строится рейтинг $\mathrm{OOH}$.

Расчет индексов онлайн-сервисов производится по результатам опроса официальных правительственных порталов и сайтов, который осуществляется в процессе подготовки очередного рейтинга. Начиная с 2012 г. можно было наблюдать стремительный рост рейтинга России по этому индексу: с 68-го места в 2010 г. она поднялась на 37-е в 2012 г. и 27-е в 2014 г.

Быстрый прогресс на первом этапе был связан с переводом услуг в электронную форму, созданием единого портала государственных и муниципальных услуг, раскрытием информации о деятельности органов власти на официальных сайтах.

На втором этапе эта динамика была поддержана расширением числа государственных услуг в электронной форме и реализацией ряда инициатив в области взаимодействия с

${ }^{1}$ UN E-Government Knowledgebase. (2018). URL: https://publicadministration.un.org/egovkb/en-us/Reports /UN-E-Government-Survey-2018 
гражданами с использованием ИКТ, таких как «Российская общественная инициатива» ${ }^{1}$, публикация открытых данных, создание портала для размещения информации о разработке государственными органами проектов нормативно-правовых актов и их общественного обсуждения ${ }^{2}$.

В рейтинге 2014 г. Россия по последним двум из четырех стадий развития онлайновых сервисов (начальные и продвинутые информационные сервисы, транзакционные и сетевые/интеграционные сервисы) набрала 51 и 35 \% от максимально возможной оценки. Этого хватило, чтобы в 2014 г. еще подняться в рейтинге (тогда указанные выше тенденции были новыми для большинства государств), но в последующие два года из-за санкций и контрсанкций по вновь введенным параметрам в России существенных подвижек не произошло. Ее стали обгонять другие страны, и в результате в 2016 г. страна перешла с 27-го на 38-е место по индексу онлайновых услуг.

Аналогичная динамика наблюдается в индексе телекоммуникационной инфраструктуры, который рассчитывается на основе пяти показателей, собираемых Международным союзом электросвязи (проникновение интернета, стационарной и мобильной телефонной связи, фиксированного и беспроводного). Высокие темпы роста телекоммуникационных показателей в 2008-2010 гг., прежде всего проникновения Интернета, позволили России подняться по индексу телекоммуникационной инфраструктуры с 63-го места в 2010 г. на 30-е в 2012 г.

В последующие годы в России темпы роста показателей телекоммуникационной инфраструктуры снизились и уже не обеспечивают дальнейшего продвижения в рейтинге. Ее стали обгонять другие страны. По соответствующему компоненту индекса ООН Россия опустилась с 30-го места в 2012 г. на 33-е место в рейтинге 2014 г. и на 38-е в 2016 г., что также определило снижение места в общем рейтинге.

Уменьшение темпов роста телекоммуникационных показателей отчасти связано с общей экономической ситуацией, а отчасти с задержкой реализации мер по снижению цифрового разрыва в России (универсальная услуга связи по широкополосному доступу в Интернет в населенных пунктах с числом жителей 250 чел. и выше была введена только в 2014 г., есть задержки в реализации этой и других мер). Некоторый «вклад» в понижение места внесло изменение методики измерения числа абонентов сотовой связи. В последние годы в России стали учитывать только активных абонентов, что снизило значение этого показателя.

Новое исследование ООН по электронному правительству отражено в табл. 1, динамика постсоветских стран на рис. 2.

Из табл. 1 видно, что самые высокие показатели в рейтинге развития электронного правительства занимают экономически высокоразвитые страны. Наибольший индекс развития электронного правительства (E-Government Development Index, EGDI), который является составным индикатором, измеряющим готовность и способность правительства использовать информационно-коммуникационные технологии в целях оказания услуг населению, оказался у Дании - 0,915 при максимальном значении 1 . При этом в 2016 г. страна находилась на 9-й позиции. Австралия и Южная Корея остались на своих местах - 2-м и 3-м соответственно. Великобритания, которая в 2016 г. возглавляла рейтинг, два года спустя расположилась на 4-й строчке.

\footnotetext{
${ }^{1}$ Российская общественная инициатива. (2019). URL: https://www.roi.ru

2 ФГИС: Единый интернет-портал для размещения информации о разработке федеральными органами исполнительной власти проектов нормативных правовых актов и результатов их публичного обсуждения. (2019). URL: https://portal.eskigov.ru/fgis/189
} 


\section{Таблица 1. Страны в рейтинге ООН по уровню развития электронного правительства в 2018 г.}

Table 1. Countries in the UN E-Government ranking in 2018

\begin{tabular}{|c|c|c|c|c|}
\hline $\begin{array}{c}№ \\
\text { ㄱп } \\
\end{array}$ & Государство & $\begin{array}{c}\text { E-Government Development } \\
\text { Index (EGDI) }\end{array}$ & Уровень развития EGDI & $\begin{array}{c}\text { Изменение мест } \\
\text { в 2018/2016 гг. }\end{array}$ \\
\hline 1 & Дания & 0,9150 & Очень высокий & +8 \\
\hline 2 & Австралия & 0,9053 & Очень высокий & - \\
\hline 3 & Республика Корея & 0,9010 & Очень высокий & - \\
\hline 4 & Великобритания & 0,8999 & Очень высокий & -3 \\
\hline 5 & Швеция & 0,8882 & Очень высокий & +1 \\
\hline 6 & Финляндия & 0,8815 & Очень высокий & -1 \\
\hline 7 & Сингапур & 0,8812 & Очень высокий & -3 \\
\hline 8 & Новая Зеландия & 0,8806 & Очень высокий & - \\
\hline 9 & Франция & 0,8790 & Очень высокий & +1 \\
\hline 10 & Япония & 0,8783 & Очень высокий & +1 \\
\hline 11 & США & 0,8769 & Очень высокий & +1 \\
\hline 16 & Эстония & 0,8486 & Очень высокий & -3 \\
\hline 31 & Израиль & 0,7998 & Очень высокий & -11 \\
\hline 32 & Россия & 0,7969 & Очень высокий & +3 \\
\hline 33 & Польша & 0,7926 & Очень высокий & +3 \\
\hline 35 & Греция & 0,7833 & Очень высокий & +8 \\
\hline 37 & Словения & 0,7714 & Очень высокий & -16 \\
\hline 38 & Беларусь & 0,7641 & Очень высокий & +11 \\
\hline 39 & Казахстан & 0,7597 & Очень высокий & -6 \\
\hline 40 & Литва & 0,7534 & Очень высокий & -17 \\
\hline 53 & Турция & 0,7112 & Высокий & +15 \\
\hline 57 & Латвия & 0,6996 & Высокий & -12 \\
\hline 60 & Грузия & 0,6893 & Высокий & +1 \\
\hline 65 & Китай & 0,6811 & Высокий & -2 \\
\hline 69 & Молдова & 0,6590 & Высокий & -4 \\
\hline 70 & Азербайджан & 0,6574 & Высокий & -14 \\
\hline 81 & Узбекистан & 0,6207 & Высокий & -1 \\
\hline 82 & Украина & 0,6165 & Высокий & -20 \\
\hline 87 & Армения & 0,5944 & Высокий & - \\
\hline 91 & Киргизия & 0,5835 & Высокий & +6 \\
\hline 96 & Индия & 0,5669 & Высокий & +11 \\
\hline 131 & Таджикистан & 0,4220 & Средний & +8 \\
\hline 147 & Туркменистан & 0,3652 & Средний & -7 \\
\hline 190 & Сомали & 0,0566 & Низкий & 0 \\
\hline
\end{tabular}

Источник: UN E-Government Knowledgebase. (2018). URL: https://publicadministration.un.org/ egovkb/en-us/Reports/UN-E-Government-Survey-2018

Следует отметить, что положительная тенденция в рейтинге наблюдалась лишь у пяти постсоветских стран. Рейтинг Российской Федерации, согласно этой классификации, поднялся до 32-го в 2018 г. $(0,7969)$ с 35-го в 2016 г., Белоруссия с 49-го в 2016 г. на 38-е в 2018 г., Таджикистан с 139-го в 2016 г. на 131-е в 2018 г., Киргизия с 97-го в 2016 г. на 91-е в 2018 г., Грузия с 61-го в 2016 г. на 60-е в 2018 г. В остальных постсоветских странах наблюдалось падение рейтинга, особенно большой у Украины, которая 


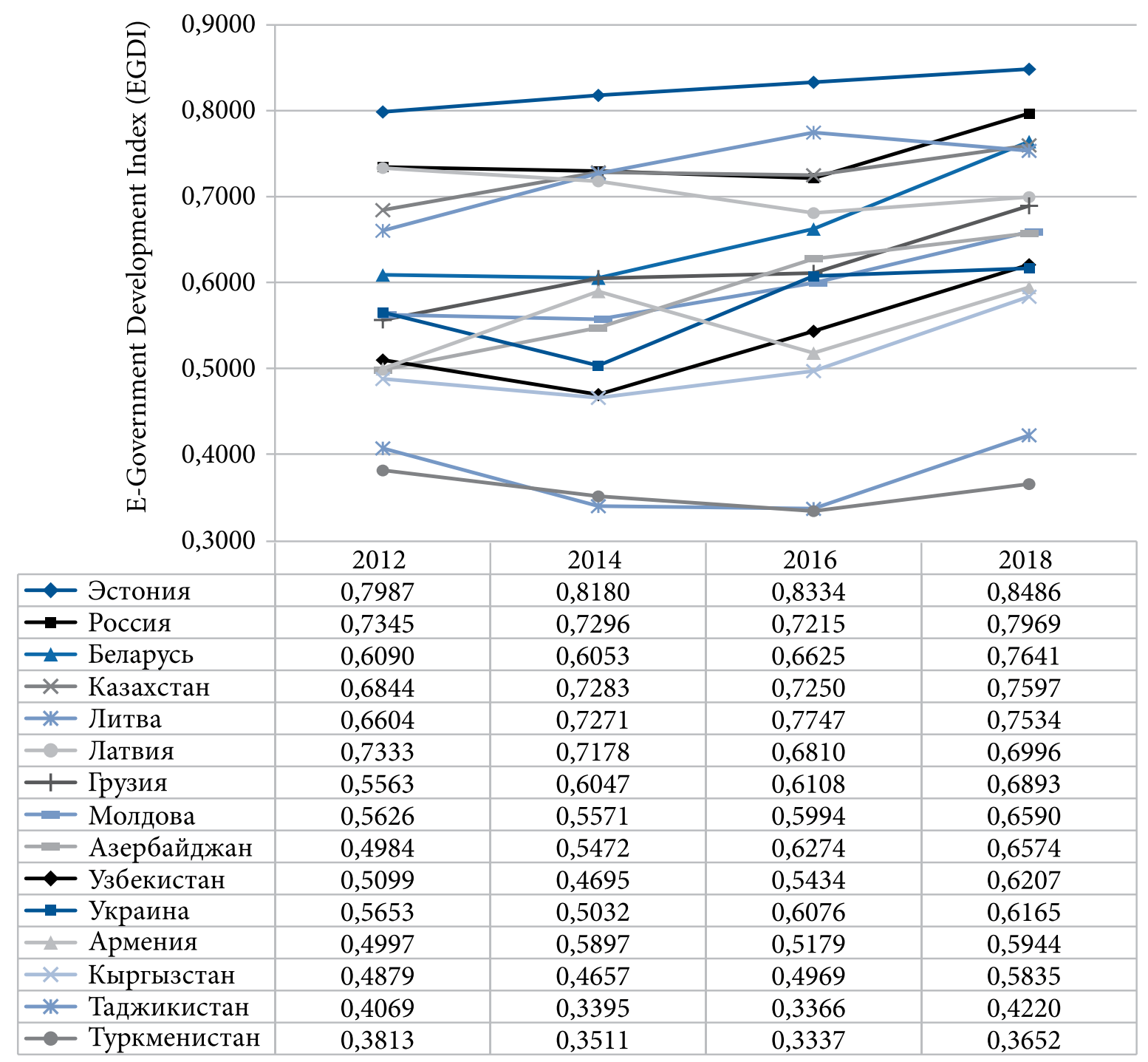

Рис. 2. Рейтинг электронного правительства ООН: динамика постсоветских республик в 2012-2018 гг. ${ }^{1}$

Fig. 2. Post-Soviet republics in the UN E-Government rating in 2012-2018

опустилась на 20 мест с 2014 г. по 2016 г. Последнее 190-е место в рейтинге все годы занимает Сомали - 0,0566.

В рейтинге E-Government Survey-2018 Белоруссия расположилась на 38-м месте с очень высоким показателем EGDI - 0,7641, Казахстану отдали 39-ю позицию тоже с очень высоким EGDI - 0,7597, в активе Молдавии 69-я строчка с высоким EGDI - 0,6590.

В группу с высоким EGDI вошла Украина (82-е место) - 0,6165, Армения (87-е место) - 0,5944, Киргизия (91-е место) - 0,5835.

В результате проведенного анализа было выявлено четкое деление по уровням развития цифровизации в постсоветских странах на три кластера:

1. Очень высокий (EGDI>0,75) - Эстония, Россия, Беларусь, Казахстан, Литва.

2. Высокий (EGDI от 0,5 до 0,75) - Латвия, Грузия, Молдова, Азербайджан, Узбекистан, Украина, Армения, Кыргызстан.

3. Средний (EGDI от 0,25 до 0,5) - Таджикистан, Туркменистан.

${ }^{1}$ Источник: UN E-Government Knowledgebase. (2018). URL: https://publicadministration.un.org/egovkb/ en-us/Reports/UN-E-Government-Survey-2018. 
В результате количественной кристаллизации направлений и развития цифровизации по шести бывшим советским республикам-«аутсайдерам» (Грузия, Молдова, Узбекистан, Украина, Армения, Кыргызстан) в работе Г. А. Шавкуна и А. В. Малышко [2018, с. 18] была проанализирована степень готовности их экономик к переходу на цифровой уровень развития по трем направлениям: уровень развития экономики, уровень информатизации общества, перспективы цифровизации экономики. Названные Г. А. Шавкуном и А. В. Малышко «аутсайдерами» страны были отнесены нами ко второму среднему кластеру с высоким уровнем развития цифровизации вместе с Латвией и Азербайджаном, которые безусловно уступают лидерам с очень высоким уровнем, но значительно опережают страны со средним уровнем, такие как Таджикистан и Туркменистан (см. рис. 2). Именно эти две страны следует отнести к аутсайдерам, так как они являются наиболее проблемными в вопросах цифровизации на постсоветском пространстве. Информации о направлениях и уровнях их развития очень мало.

В Таджикистане действует Государственная программа развития и внедрения ИКТ на 2014-2017 гг., основными направлениями которой являются [Турдибеков, 2018]:

- совершенствование законодательства и нормативно-технической базы (технических регламентов) в сфере ИКТ;

- разработка и внедрение новых приложений ИКТ, развитие информационной и телекоммуникационной инфраструктуры и создание единого информационного пространства;

- информационная безопасность.

Президент Туркменистана 30 ноября 2018 г. на заседании правительства утвердил Концепцию развития цифровой экономики в стране в 2019-2025 гг. «Цифровой Туркменистан». Цель Концепции - стимулирование развития ИКТ и «...повышение вклада этого сектора в ВВП страны, а также устранение цифровой разницы в быту населения велаятов, городов и сел» ${ }^{1}$. Реализовать ее туркменское правительство планирует в три этапа: первый - в 2019 г., второй - в 2020-2023 гг., третий - в 2024-2025 гг.

Результаты прогнозирования рейтингового индикатора E-Government Development Index (EGDI) приведены в табл. 2.

\section{Таблица 2. Прогнозирование тенденций развития цифровой экономики (EGDI) в постсоветских странах на 2020 г.}

Table 2. Forecast for the digital economy development trends (EGDI) in the post-Soviet countries in 2020

\begin{tabular}{|c|c|c|c|c|c|c|c|c|}
\hline \multirow[b]{2}{*}{\begin{tabular}{|c} 
№ \\
п/п
\end{tabular}} & \multirow[b]{2}{*}{ Страна } & $\beta_{\mathrm{cp}}$ & $\sigma$ & $\beta^{\star}=\beta_{\mathrm{cp}} / \sigma$ & $\beta^{* 2}$ & $\alpha=\beta^{*} / \ddot{O} \Sigma \beta^{* 2}$ & $\gamma=\alpha / \sum \alpha$ & \multirow[b]{2}{*}{$\begin{array}{l}\text { Прогноз } \\
\text { на } 2020 \text { г. }\end{array}$} \\
\hline & & 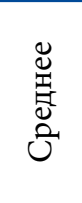 & 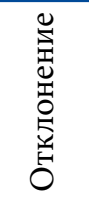 & 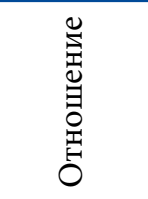 & 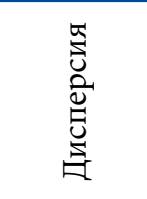 & 预 & 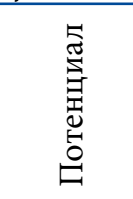 & \\
\hline 1 & Эстония & 0,82 & 0,02 & 44,60 & 1988,87 & 0,62 & 0,26 & 0,8902 \\
\hline 2 & Россия & 0,75 & 0,03 & 24,88 & 619,16 & 0,34 & 0,14 & 0,8359 \\
\hline 3 & Беларусь & 0,66 & 0,06 & 10,30 & 106,08 & 0,14 & 0,06 & 0,8015 \\
\hline 4 & Казахстан & 0,72 & 0,03 & 27,08 & 733,40 & 0,38 & 0,16 & 0,7969 \\
\hline 5 & Литва & 0,73 & 0,04 & 16,95 & 287,44 & 0,23 & 0,10 & 0,7903 \\
\hline 6 & Молдова & 0,59 & 0,04 & 14,64 & 214,20 & 0,47 & 0,18 & 0,7396 \\
\hline 7 & Азербайджан & 0,58 & 0,06 & 9,23 & 85,15 & 0,27 & 0,11 & 0,7360 \\
\hline 8 & Латвия & 0,71 & 0,02 & 36,13 & 1305,38 & 0,50 & 0,21 & 0,7339 \\
\hline 9 & Грузия & 0,62 & 0,05 & 12,91 & 166,59 & 0,18 & 0,07 & 0,7231 \\
\hline
\end{tabular}

${ }^{1}$ Информационное агентство Туркменистана «Туркмен довлет хабарлары». (2019). URL: http://tdh.gov. $\mathrm{tm} / \mathrm{ru}$ 
Окончание таблицы 2

Table 2 (concluded)

\begin{tabular}{|c|c|c|c|c|c|c|c|c|}
\hline & & $\beta_{\mathrm{cp}}$ & $\sigma$ & $\beta^{\star}=\beta_{\mathrm{cp}} / \sigma$ & $\beta^{* 2}$ & $\alpha=\beta^{\star} / O ̈ \Sigma \beta^{* 2}$ & $\gamma=\alpha / \sum \alpha$ & \\
\hline $\begin{array}{l}\text { № } \\
\text { п/п }\end{array}$ & Страна & 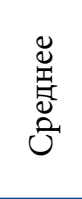 & 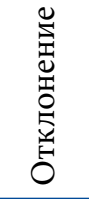 & 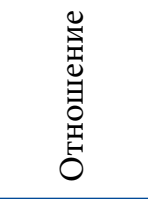 & 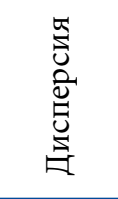 & $\stackrel{\text { ta }}{\stackrel{5}{\sigma}}$ & 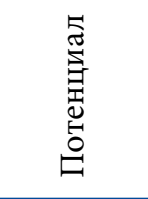 & $\begin{array}{l}\text { Прогноз } \\
\text { на } 2020 \text { г. }\end{array}$ \\
\hline 10 & Узбекистан & 0,54 & 0,06 & 9,65 & 93,14 & 0,28 & 0,11 & 0,6949 \\
\hline 11 & Украина & 0,57 & 0,04 & 12,80 & 163,83 & 0,38 & 0,15 & 0,6902 \\
\hline 12 & Армения & 0,55 & 0,04 & 13,06 & 170,51 & 0,38 & 0,15 & 0,6655 \\
\hline 13 & Кыргызстан & 0,51 & 0,04 & 11,36 & 129,03 & 0,33 & 0,13 & 0,6533 \\
\hline 14 & Таджикистан & 0,38 & 0,04 & 9,75 & 95,09 & 0,29 & 0,11 & 0,4724 \\
\hline 15 & Туркменистан & 0,36 & 0,02 & 20,38 & 415,47 & 0,60 & 0,24 & 0,4089 \\
\hline
\end{tabular}

Прогнозирование тенденций цифровизации в постсоветских странах можно определить статистическими методами, но рациональнее, по нашему мнению, рассчитать их с помощью цепей Маркова [Кельберт, Сухов, 2010] и Шаланова [Шаланов, 2008].

\section{Обсуждение результатов}

Цифровая экономика становится основой инновационного развития народного хозяйства в целом и оказывает существенное влияние на образование, здравоохранение, банковское дело, транспортное сообщение, сетевую торговлю, энергетику, и многие другие отрасли. Широкое использование таких цифровых технологий, как Интернет вещей, большие данные (Big Data), мобильные устройства и девайсы, трансформируют виды социально-экономического развития и их институты. Возникают инновационные виды кооперации и координации экономических субъектов для совместного взаимодействия при решении определенного круга задач (sharing economy).

Результаты прогнозирования рейтингового индикатора EGDI) выявили следующие тенденции развития цифровой экономики в постсоветских государствах:

1. Эстония - лидер стран первого кластера показывает стабильную (близкую к линейной) тенденцию роста ЦЭ, оставаясь в первой двадцатке стран с очень высоким уровнем развития на всем периоде исследований.

2. Россия - стабильно занимает второе место в первом кластере, замедлила свой рост в период введения санкцией и контрсанкций (2014-2016 гг.), затем вновь стабилизировала рост.

3. Беларусь, Казахстан и Литва - с небольшим отрывом друг от друга разделяют третью позицию в первом кластере. Беларусь демонстрирует стабильную (близкую к линейной) тенденцию роста ЦЭ, ежегодно поднимаясь минимум на пять мест в рейтинге. Казахстан и Литва показывают неустойчивую тенденцию, причем заметно негативную в последние годы.

4. Во втором кластере (высокий уровень развития) следует ожидать, что Латвия и Грузия, характеризующиеся замедлением роста, поменяются местами в рейтинге соответственно с Молдовой и Азербайджаном, которые показывают в последние годы тенденцию к значительному росту. Узбекистан, Украина, Армения, Кыргызстан наиболее вероятно сохранят свои места в рейтинге.

5. Страны третьего кластера (со средним уровнем развития) Таджикистан и Туркменистан также сохранят свои места в рейтинге, однако у Таджикистана есть шанс приблизиться к группе стран второго кластера. 


\section{Заключение}

Цифровизация экономики охватила все 15 республик бывшего Советского Союза. Процесс трансформации в цифровой экономике развивается неравномерно, институциональная среда в сфере ИКТ остается фрагментированной. В выявленных тенденциях скрываются риски цифровой экономики: технологические [Chernyakov, Chernyakova, 2018, p. 99], политические, экономические, социальные и психологические [Salehan, Kim, Lee, 2018, p. 725]. Важнейшей задачей остается выработка сбалансированных сценариев, способных максимизировать положительные эффекты и минимизировать риски.

Расширение использования цифровых устройств дало импульс к созданию концепции Big Data. Постоянное увеличение потоков данных (их объемы измеряются терабайтами и петабайтами), которые передаются в режиме реального времени, обрабатываются и используются для принятия решений, стало возможным благодаря этой концепции. Работа с большими данными является основой для развития цифровой экономики, обеспечивающей новое качество анализа социально-экономических показателей. Совершенствование вычислительной мощности, технологии облачной обработки информации позволит разрабатывать модели и прогнозировать социально-экономическое развитие.

\section{Источники}

Гвилия Н. А., Парфёнов А. В., Шульженко Т. Г. (2019). Управление интегрированными межкорпоративными логистическими системами в условиях цифровой экономики // Управленец. T. 10, № 1. C. 40-51. DOI: 10.29141/2218-5003-2019-10-1-4

Ерженин Р. В. (2018). Электронное правительство России: обзор научных публикаций и исследований // Вопросы государственного и муниципального управления. Public administration issues. № 3. С. 205-228.

Кельберт М. Я., Сухов Ю. М. (2010). Вероятность и статистика в примерах и задачах. Т. II: Марковские цепи как отправная точка теории случайных процессов и их приложения. М.: МЦНМО, 2010. 295 c.

Маркова В. Д. (2018). Влияние цифровой экономики на бизнес. ЭКО. Т. 48, № 12. С. 7-22. DOI: http://dx.doi.org/10.30680/ECO0131-7652-2018-12-7-22

Степанов В. В., Черняков М. К., Дидикин А. Б. и др. (2017). Комплексная оценка социальноэкономического развития города Искитима Новосибирской области: монография. Новосибирск: Изд-во НГТУ. 226 с.

Суходолов А. П., Слободняк И. А., Маренко В. А. (2019). Факторная модель оценки состояния цифровой экономики // Известия Уральского государственного экономического университета. T. 20, № 1. C. 13-24. DOI: 10.29141/2073-1019-2019-20-1-2

Турдибеков Б. А. (2018). Современное состояние формирования цифровой экономики в Республике Таджикистан // Вестник Евразийской науки. № 1. URL: https:/esj.today/ PDF/52ECVN118.pdf

Шавкун Г. А., Малышко А. В. (2018). Развитие цифровой экономики в постсоветских государствах // Вестник ТвГУ. Серия: Экономика и управление (3). С. 18-29.

Шаланов Н. В. (2008). Системный анализ. Кибернетика. Синергетика: математические методы и модели. Экономические аспекты: монография / Н. В. Шаланов. Новосибирск, 2008. 287 с.

Alkhatri N. S., Zaki N., Mohammed E., Shallal M. (2016). The use of data mining techniques to predict the ranking of e-government services. 12th International Conference on Innovations in Information Technology (IIT), pp. 173-178.

Chernyakov M., Chernyakova M. (2018). Technological risks of the digital economy// Корпоративные финансы. Т. 12, № 4. С. 99-109. URL: https://cfjournal.hse.ru/article/view/8132/9156.

Choi H., Park M. J. (2019). Evaluating the efficiency of governmental excellence for social progress: Focusing on low- and lower-middle-income countries. Social Indicators Research, vol. 141, no. 1, pp. 111-130. 
Ebbers W. E., Jansen M. G. M., Deursen A. J. A. M., van (2016). Impact of the digital divide on e-government: Expanding from channel choice to channel usage. Government Information Quarterly, vol. 33, no. 4, pp. 685-692.

Filatova O., Balabanova S., Golubev V., Ibragimov I. (2017). E-participation in EEU countries: A case study of government websites. International Conference on Electronic Governance and Open Society. Challenges in Eurasia (EGOSE). Saint Petersburg, pp. 145-151.

Janowski T. (2015). Digital government evolution: From transformation to contextualization. Government Information Quarterly, vol. 32, no. 3, pp. 221-236.

Kabbar E. F. (2018, April 25-26). Reflecting on a decade of measuring e-government readiness using EGDI: Has anything changed? 31st International Business Information Management Association Conference (IBIMA) "Innovation Management and Education Excellence through Vision". Milan, Italy, pp. 5107-5113.

Kassen M. (2019). Building digital state: Understanding two decades of evolution in Kazakh e-government project. Online Information Review, vol. 43, no. 2, pp. 301-323.

Lee-Geiller S., Lee T. (David). (2019). Using government websites to enhance democratic E-governance: A conceptual model for evaluation. Government Information Quarterly, vol. 36, no. 2, pp. 208-225. DOI: $10.1016 /$ j.giq.2019.01.003.

Lobova S. V., Ragulina Y. V., Averin A. V., Simonov S. Y., Semenova E. I. (2018). Methods of digitization of the Russian Economy with the help of new internet technologies. 5th National Scientific and Practical Conference on Perspectives on the Use of New Information and Communication Technology (ICT) in the Modern Economy Location. Pyatigorsk, pp. 221-228. DOI: 10.1007/978-3-319-90835-9_26

Maerz S. F. (2016). The electronic face of authoritarianism: E-government as a tool for gaining legitimacy in competitive and non-competitive regimes. Government Information Quarterly, vol. 33, no. 4, pp. 727-735.

Moreno Enguix M. del Rocio, Lorente Bayona L. V., Gras-Gil E. (2019). Can e-government serve as a tool for public authorities to manage public resources more efficiently? Journal of Global Information Management, vol. 27, no. 2, pp. 122-135. DOI: 10.4018/JGIM.2019040107.

Nam T. (2019). Does e-government raise effectiveness and efficiency? Examining the cross-national effect. Journal of Global Information Management, vol. 27, no. 3, pp. 120-138. DOI: 10.4018/ JGIM.2019070107.

Salehan M., Kim D. J., Lee J.-N. (2018). Are there any relationships between technology and cultural values? A country-level trend study of the association between information communication technology and cultural values. Information \& Management, vol. 55, pp. 725-745.

Todorut A. V., Tselentis V. (2018). Digital technologies and the modernization of public administration. Quality - Access to Success, vol. 19, pp. 73-78.

Whitmore A. (2012). A statistical analysis of the construction of the United Nations E-Government Development Index. Government Information Quarterly, vol. 29, no. 1, pp. 68-75.

Wirtz B. W., Daiser P. (2018). A meta-analysis of empirical e-government research and its future research implications. International Review of Administrative Sciences, vol. 84, no. 1, pp. 144-163. DOI: https://doi.org/10.1177/0020852315599047.

\section{Информация об авторах}

Черняков Михаил Константинович, доктор экономических наук, профессор кафедры аудита, учета и финансов Новосибирского государственного технического университета, РФ, 630073, г. Новосибирск, пр. К. Маркса, 20

Контактный телефон: +7 (383) 315-32-45, e-mail: chernyakov@corp.nstu.ru

Чернякова Мария Михайловна, кандидат экономических наук, доцент кафедры менеджмента Сибирского института управления - филиала Российской академии народного хозяйства и государственной службы при Президенте Российской Федерации, 630102, РФ, г. Новосибирск, ул. Нижегородская, 6

Контактный телефон: +7 (383) 373-13-93, e-mail: chernjakova@siu.ranepa.ru 
Mikhail K. Chernyakov Novosibirsk State Technical University, Novosibirsk, Russia

Maria M. Chernyakova Siberian Institute of Management - branch of RANEPA, Novosibirsk, Russia

\title{
Forecasting trends in e-government development in the post-Soviet countries
}

\begin{abstract}
Though digital technologies are the driving force of innovations and economic growth worldwide, they cause numerous problems. One of such problems is uneven formation of the digital economy in the post-Soviet countries. The research aims to compare the digitalization processes in the territories of the post-Soviet countries to conclude about the problems and prospects of the digital economy in the post-Soviet space. The authors apply the system, comprehensive and territorial approaches with the use of functional and comparative analysis for economic interpretation of the findings. The research novelty is the classification of the postSoviet countries according to the level of the digital economy development. The analysis of the post-Soviet economies' readiness to the digital transformation indicates three levels of readiness: medium $(0.25<$ EGDI $<0.5)$, high $(0.5<\mathrm{EGDI}<0.75)$ and very high $(\mathrm{EGDI}>0.75)$. As a result of the ranking, the cluster with very high level of digitalisation includes five countries of the northwest, the cluster with high level of digitalisation encompasses eight countries of the southwest, and the cluster with the medium level lists two countries of the southeast of the post-Soviet space. The major challenges during the transformation into the digital economy are an overall tense economic situation and delayed measures on narrowing the digital divide, which lead to a decrease in the growth rates of telecommunication indicators of the former Soviet Union countries. The authors argue that the most important task for these countries is to develop balanced methods for handling these challenges, which should be able to maximize the positive effects and keep the risks of the digital economy to a minimum.
\end{abstract}

Keywords: forecasting; tendency; digital economy; development index; ranking; electronic government; management.

Acknowledgements: The reported study was prepared with the financial support of the Novosibirsk State Technical University (project C19-12).

For citation: Chernyakov M. K., Chernyakova M. M. Prognozirovanie tendentsiy razvitiya tsifrovogo pravitel'stva (e-government) $\mathrm{v}$ postsovetskikh stranakh [Forecasting trends in e-government development in the post-Soviet countries]. Journal of New Economy, 2019, vol. 20, no. 4, pp. 5-21. DOI: 10.29141/2073-1019-2019-20-4-1

Received April 29, 2019.

\section{References}

Gviliya N. A., Parfyonov A. V., Shulzhenko T. G. (2019). Upravlenie integrirovannymi mezhkorporativnymi logisticheskimi sistemami v usloviyakh tsifrovoy ekonomiki [Managing integrated interorganizational logistic systems in the digital economy]. Upravlenets = The Manager, vol. 10, no. 1, pp. 40-51. DOI: 10.29141/2218-5003-2019-10-1-4. (in Russ.)

Erzhenin R.V. (2018). Elektronnoe pravitel'stvo Rossii: obzor nauchnykh publikatsiy i issledovaniy [Russian e-government: Review of scientific publications and research]. Voprosy gosudarstvennogo $i$ munitsipal'nogo upravleniya. Public administration issues, no. 3, pp. 205-228. (in Russ.)

Kelbert M. Ya., Sukhov Yu. M. (2010). Veroyatnost' i statistika v primerakh i zadachakh. T. II: Markovskie tsepi kak otpravnaya tochka teorii sluchaynykh protsessov $i$ ikh prilozheniya [Probability and statis- 
tics in cases and tasks. Vol. II: Markovian chains as the starting point for the theory of random processes and their application]. Moscow: MTsNMO Publ., 2010. 295 p. (in Russ.)

Markova V. D. (2018). Vliyanie tsifrovoy ekonomiki na biznes [Influence of digital economy on business]. $E K O=E C O$, vol. 48, no. 12, pp. 7-22. DOI: http://dx.doi.org/10.30680/ECO0131-7652-2018-127-22. (in Russ.)

Stepanov V. V. (ed.), Chernyakov M. K., Didikin A. B., et al. (2017). Kompleksnaya otsenka sotsial'noekonomicheskogo razvitiya goroda Iskitima Novosibirskoy oblasti [Complex assessment of social and economic development of the Iskitim town in the Novosibirsk oblast]. Novosibirsk: Novosibirsk State Technical University. 226 p. (in Russ.)

Sukhodolov A. P., Slobodnyak I. A., Marenko V. A. Faktornaya model' otsenki sostoyaniya tsifrovoy ekonomiki [Factor model for assessing the state of the digital economy]. Izvestiya Uralskogo gosudarstvennogo ekonomicheskogo universiteta = Journal of the Ural State University of Economics, 2019, vol. 20, no. 1, pp. 13-24. DOI: 10.29141/2073-1019-2019-20-1-2. (in Russ.)

Turdibekov B. A. (2018). Sovremennoe sostoyanie formirovanie tsifrovoy ekonomiki v Respubliki Tadzhikistan [The modern state of the formation of the digital economy in the Republic of Tajikistan]. Vestnik Evraziyskoy nauki = The Eurasian Scientific Journal, vol. 10, no. 1. Available at: https://esj.today/ PDF/52ECVN118.pdf. (in Russ.)

Shavkun G. A., Malyshko A. V. (2018). Razvitie tsifrovoy ekonomiki v postsovetskikh gosudarstvakh [Development of digital economy in former USSR countries]. Vestnik TvGU. Seriya: Ekonomika i upravlenie $=$ Proceedings of Tver State University. Series: Economics and Management, no. 3, pp. 18-29. (in Russ.)

Shalanov N. V. (2008). Sistemnyy analiz. kibernetika. sinergetika: matematicheskie metody i modeli. Ekonomicheskie aspekty [System analysis. Cybernetics. Synergetics: Mathematical methods and models. Economic aspects]. Novosibirsk. 287 p. (in Russ.)

Alkhatri N. S., Zaki N., Mohammed E., Shallal M. (2016). The use of data mining techniques to predict the ranking of e-government services. 12th International Conference on Innovations in Information Technology (IIT), pp. 173-178.

Chernyakov M., Chernyakova M. (2018). Technological risks of the digital economy. Korporativnye finansy = Journal of Corporate Finance Research, vol. 12, no. 4, pp. 99-109. URL: https://cfjournal.hse.ru/ article/view/8132/9156.

Choi H., Park M. J. (2019). Evaluating the efficiency of governmental excellence for social progress: Focusing on low- and lower-middle-income countries. Social Indicators Research, vol. 141, no. 1, pp. 111-130.

Ebbers W. E., Jansen M. G. M., Deursen A. J. A. M., van (2016). Impact of the digital divide on e-government: Expanding from channel choice to channel usage. Government Information Quarterly, vol. 33, no. 4, pp. 685-692.

Filatova O., Balabanova S., Golubev V., Ibragimov I. (2017). E-participation in EEU countries: A case study of government websites. International Conference on Electronic Governance and Open Society. Challenges in Eurasia (EGOSE). Saint Petersburg, pp. 145-151.

Janowski T. (2015). Digital government evolution: From transformation to contextualization. Government Information Quarterly, vol. 32, no. 3, pp. 221-236.

Kabbar E. F. (2018, April 25-26). Reflecting on a decade of measuring e-government readiness using EGDI: Has anything changed? 31st International Business Information Management Association Conference (IBIMA) "Innovation Management and Education Excellence through Vision". Milan, Italy, pp. 5107-5113.

Kassen M. (2019). Building digital state: Understanding two decades of evolution in Kazakh e-government project. Online Information Review, vol. 43, no. 2, pp. 301-323.

Lee-Geiller S., Lee T. (David). (2019). Using government websites to enhance democratic E-governance: A conceptual model for evaluation. Government Information Quarterly, vol. 36, no. 2, pp. 208-225. DOI: 10.1016/j.giq.2019.01.003

Lobova S. V., Ragulina Y. V., Averin A. V., Simonov S. Y., Semenova E. I. (2018). Methods of digitization of the Russian Economy with the help of new internet technologies. 5th National Scientific and 
Practical Conference on Perspectives on the Use of New Information and Communication Technology (ICT) in the Modern Economy Location. Pyatigorsk, pp. 221-228. DOI: 10.1007/978-3-319-90835-9_26

Maerz S. F. (2016). The electronic face of authoritarianism: E-government as a tool for gaining legitimacy in competitive and non-competitive regimes. Government Information Quarterly, vol. 33, no. 4, pp. 727-735.

Moreno Enguix M. del Rocio, Lorente Bayona L. V., Gras-Gil E. (2019). Can e-government serve as a tool for public authorities to manage public resources more efficiently? Journal of Global Information Management, vol. 27, no. 2, pp. 122-135. DOI: 10.4018/JGIM.2019040107.

Nam T. (2019). Does e-government raise effectiveness and efficiency? Examining the cross-national effect. Journal of Global Information Management, vol. 27, no. 3, pp. 120-138. DOI: 10.4018/ JGIM.2019070107.

Salehan M., Kim D. J., Lee J.-N. (2018). Are there any relationships between technology and cultural values? A country-level trend study of the association between information communication technology and cultural values. Information \& Management, vol. 55, pp. 725-745.

Todorut A. V., Tselentis V. (2018). Digital technologies and the modernization of public administration. Quality - Access to Success, vol. 19, pp. 73-78.

Whitmore A. (2012). A statistical analysis of the construction of the United Nations E-Government Development Index. Government Information Quarterly, vol. 29, no. 1, pp. 68-75.

Wirtz B. W., Daiser P. (2018). A meta-analysis of empirical e-government research and its future research implications. International Review of Administrative Sciences, vol. 84, no. 1, pp. 144-163. DOI: https://doi.org/10.1177/0020852315599047.

\section{Information about the authors}

Mikhail K. Chernyakov, Dr. Sc. (Econ.), Prof. of Audit, Accounting and Finance Dept., Novosibirsk State Technical University, 20 K. Marksa Ave., Novosibirsk, 630073, Russia Phone: +7 (383) 315-32-45, e-mail: chernyakov@corp.nstu.ru

Maria M. Chernyakova, Cand. Sc. (Econ.), Associate Prof. of Management Dept., Siberian Institute of Management - branch of RANEPA, 6 Nizhegorodskaya St., Novosibirsk, 630102, Russia Phone: +7 (383) 373-13-93, e-mail: chernjakova@siu.ranepa.ru

(C) Черняков М. К., Чернякова М. М., 2019 
М. А. Юдина Омский государственный технический университет, г. Омск, Российская Федерация

\title{
Методические аспекты диагностики макрорегиональных структурных сдвигов
}

\begin{abstract}
Аннотащия. Одной из ключевых задач стратегического управления пространственным развитием государства является регулирование межрегиональной дифференциации уровней социально-экономического развития. Статья посвящена проблеме совершенствования методического инструментария региональной диагностики как одной из важнейших подсистем процесса стратегического планирования и прогнозирования. Методологическую базу исследования составляют положения теории региональных саморазвивающихся социально-экономических систем, базирующейся на принципах системно-синергетической парадигмы. Методика исследования включает три этапа: общую оценку структурных сдвигов; анализ динамики структурных соотношений; построение мультипараметрической модели структурной диагностики. Использование индикативных свойств мультипараметрической модели позволило выявить наметившиеся структурные сдвиги в макрорегиональной системе по комплексу исследуемых параметров. Результаты исследования по данным 2017 г. показали, что наблюдается улучшение качественных характеристик системы. Она начинает постепенно меняться, трансформироваться, часть прежних связей исчезает, но в большинстве макрорегионов отмечаются положительные тенденции, уровень дифференциации снижается. Исследование может применяться на предварительном (диагностическом) этапе формирования региональной составляющей прогнозов социально-экономического развития, а также при оценке результатов реализации стратегии пространственного развития.
\end{abstract}

Ключевые слова: прогнозирование; системно-синергетический подход; теория региональных саморазвивающихся систем; кибернетический подход; макрорегиональная система; структурная диагностика; мультипараметрическая модель; структурный индикатор.

Для цитирования: Юдина М. А. Методические аспекты диагностики макрорегиональных структурных сдвигов // Journal of New Economy. 2019. T. 20, № 4. C. 22-46. DOI: 10.29141/2073-1019-2019-20-4-2

Дата поступления: 25 марта 2019 г.

\section{Введение}

$\mathrm{B}$ настоящее время продолжается активное формирование системы стратегического государственного планирования и прогнозирования, основы которой были определены Федеральным законом № 172-Ф3².

Анализ научных публикаций ведущих представителей российских региональных школ показывает, что региональная экономическая наука достигла такого уровня зрелости, который позволяет ее методологическому и методическому аппарату решать многомерные задачи исследования общественных процессов [Силин, Анимица, Новикова, 2017]. При этом большинство стратегических документов, разрабатываемых на

${ }^{1}$ Федеральный закон от 28.06.2014 г. №172 «О стратегическом планировании в Российской Федерации». URL: http://www.consultant.ru 
всех уровнях государственного управления, «...страдают фундаментальной неполнотой - они не включают пространственного измерения организации производительных сил в обозримом будущем» [Силин, Анимица, Новикова, 2017, с. 684]. К тому же отсутствует единообразная, взаимосвязанная система оценки и прогнозирования финансового развития территориальных образований [Совершенствование теоретико-методологических основ ..., 2017, с. 4], без чего невозможно наладить эффективную обратную связь, т. е. реально оценить результаты реализации стратегий. Например, при разработке региональных разделов ежегодных прогнозов социально-экономического развития Российской Федерации, а также Прогноза социально-экономического развития Российской Федерации на период до 2024 года использовался метод механического сведения прогнозных оценок, полученных на уровне субъектов Российской Федерации. Это противоречит базовым принципам системного подхода.

В разделах, посвященных социально-экономическому развитию субъектов РФ, дается характеристика изменений основных макроэкономических показателей. При этом конкурентные преимущества регионов, факторы и ограничения их развития не выделены, возможные стратегические риски и их последствия не раскрыты. Недостаточный учет региональной составляющей особенно проявляется в Прогнозе социально-экономического развития Российской Федерации на период до 2036 года, где региональный раздел отсутствует, прогнозная структура экономического роста сформирована только в отраслевом разрезе, а прогноз ВРП не представлен.

На наш взгляд, основной проблемой реализации процесса государственного планирования и прогнозирования социально-экономического развития регионов является недостаточное использование методологических положений и методического инструментария, наработанных российской региональной наукой, что отмечается в постановлении Совета Федерации ${ }^{1}$. При этом речь идет не о директивном внедрении «шаблонов», а о формировании единой методологии разработки стратегий социально-экономического развития с учетом специфических региональных возможностей [Саморазвивающиеся социально-экономические системы: теория..., 2011].

В 2019 г. Правительством РФ утверждена Стратегия пространственного развития до 2025 года. Недостатки данного документа в методологическом, методическом, управленческом, организационном и других аспектах были выявлены и обозначены еще на этапе обсуждения проекта [Рой, 2018; Бухвальд, Валентик, 2018; Лебединская, 2018].

Отметим, что существенным методологическим упущением Стратегии пространственного развития является отсутствие системного представления результатов региональной диагностики, представлены только выводы, не подкрепленные какими-либо экономическими показателями и соответствующей аналитической интерпретацией. Так, в качестве одной из основных тенденций пространственного развития Российской Федерации определено сокращение межрегиональных социально-экономических диспропорций. Не рассматривая в данной статье экономическое содержание декларируемого вывода, отметим, что в следующем разделе документа в качестве первой проблемы указан «...высокий уровень межрегионального социально-экономического неравенства». Однако в предыдущем разделе констатировалось: «В Российской Федерации в течение последних 10 лет в результате проводимой государственной политики регионального развития

\footnotetext{
${ }^{1}$ Постановление Совета Федерации Федерального Собрания РФ от 24 октября 2018 г. №463-СФ «О прогнозе социально экономического развития Российской Федерации на 2019 год и на плановый период 2020 и 2021 годов». URL: http://www.council.gov.ru
} 
наблюдается сокращение межрегиональных социально-экономических диспропорций» ${ }^{1}$. Наличие подобных противоречий свидетельствует о недостаточной проработанности диагностического этапа.

В Бюллетене о текущих тенденциях российской экономики «Динамика и структура инвестиций в основной капитал» (октябрь 2018 г.) Аналитический центр при Правительстве РФ по итогам анализа объемов инвестиций в основной капитал в РФ отмечает тенденцию восстановительного роста. Согласно официальным статистическим данным, прирост инвестиций в 2017 г. составил 4,4 \% (от $+1,4 \%$ в первом квартале до $+6,4 \%$ в четвертом квартале). При этом выводы по результатам анализа региональных трендов достаточно противоречивы. По итогам 2017 г. инвестиции в основной капитал в развитых и среднеразвитых регионах по-прежнему оставались ниже уровня 2013 г. Рост инвестиций (относительно 2013 г.) наблюдался в сырьевых экспортоориентированных регионах, финансово-экономических центрах и менее развитых регионах (в соответствии с синтетической классификацией регионов Аналитического центра при Правительстве РФ).

Следовательно, оценка устойчивости обозначенной тенденции восстановительного роста требует дальнейшего анализа региональной составляющей. Наметились ли структурные сдвиги, позволяющие говорить о системных изменениях в экономике? Полагаем, что ответить на этот вопрос можно с использованием методического инструментария структурной диагностики.

Цель исследования - апробация методического инструментария для диагностики макрорегиональных структурных сдвигов.

Задачами исследования являются:

- предварительная оценка существенности структурных сдвигов на основе интегральных показателей структурных различий;

- выявление структурных соотношений между параметрами и анализ их динамики;

- построение теоретико-графовой модели макрорегиональной системы;

- анализ и интерпретация результатов моделирования на основе изучения свойств структурного индикатора - графа доминирования;

- оценка результативности методических подходов структурной диагностики к исследованию макрорегиональной системы.

\section{Эволюция методов региональной диагностики}

Рассмотрим ключевые аспекты становления и развития методологической и инструментальной базы региональной диагностики.

Как известно, американский ученый У. Айзард полагал, что региональная наука представляет собой системное изучение пространства на основе соединения широкого применения математических моделей (см.: [Саушкин, 1973]). В работе У. Айзарда [1966] адаптируются методы макроэкономки для исследования регионов и межрегиональных связей.

Первой отечественной научной работой, в которой излагались в систематической форме методы региональной диагностики и раскрывались возможности их применения, была монография О. Г. Дмитриевой. Рассматривая инструментарий диагностики, О. Г. Дмитриева $[1992$, с. 6] различает аналитические, экспертные методы и диагностику на моделях. Автор отмечает, что диагностика на моделях чрезвычайно трудна, она может быть осуществлена лишь при высокой степени изученности объекта, наличии полной

\footnotetext{
${ }^{1}$ Распоряжение Правительства РФ от 13 февраля 2019 г. № 207-р «Об утверждении Стратегии пространственного развития Российской Федерации на период до 2025 года». URL: https://www.grant.ru
} 
информации о его параметрах. Следовательно, моделирование наиболее полезно уже после диагностики - на стадии прогнозирования реакции объекта на различные воздействия [Дмитриева, 1992, с. 11-12].

В качестве значимой научной работы, посвященной методологии региональной экономической диагностики, можно отметить монографию Р. И. Шнипера, в которой предмет, задачи и принципы экономической диагностики изложены с точки зрения концепции регионального воспроизводственного процесса [Шнипер, 1996].

Как известно, большой вклад в развитие экономико-математического моделирования территориальных систем, а значит, и в формирование инструментального потенциала региональной диагностики внесла новосибирская научная школа. С первой половины 1960-х годов в Институте экономики и организации промышленного производства Сибирского отделения Академии наук СССР (ИЭОПП СО АН СССР) под руководством А. Г. Аганбегяна в тесном сотрудничестве с Институтом математики Сибирского отделения Академии наук СССР, который возглавлялся Л. В. Канторовичем, начались работы по экономико-математическому моделированию экономики СССР. Исследования в значительной степени базировались на использовании инструментария оптимального планирования межотраслевых моделей, теории общего экономического равновесия, теории игр, математической статистики. Первые варианты разработанной оптимизационной межрегиональной (многорегиональной) межотраслевой модели (ОМMM) были опубликованы в 1965 г. [Гранберг, 1965]. Совершенствование ОМММ осуществлялось на протяжении нескольких десятилетий. Наиболее полный обзор исследований по этому направлению представлен в работах А. Г. Гранберга [2007], А. Г. Гранберга, В. И. Суслова, С. А. Суспицына [2007].

В фундаментальной монографии под редакцией С. А. Суспицына «Оптимизация территориальных систем» [2010] обобщены многолетние итоги исследовательской деятельности новосибирской научной школы. В рамках методологии пространственного развития на разных уровнях территориальной иерархии выделены следующие комплексы экономико-математических моделей и методов:

- методы оценки неравномерности пространственного развития, межрегиональной социально-экономической дифференциации;

- методология и опыт анализа, моделирования и прогнозирования межрегиональных экономических взаимосвязей;

- прогнозирование регионального развития в системе межуровневых взаимодействий;

- институциональные условия формирования пространственной экономики и инструменты региональной политики.

При этом авторы подчеркивают, что «...любые прогнозно-аналитические исследования в научных обоснованиях вариантов программных решений будущего развития страны, ее крупных секторов и регионов должны начинаться и заканчиваться оценкой межрегиональных различий...» [Оптимизация территориальных..., 2010].

Ведущие ученые неоднократно отмечали актуальность формирования методологической и методической базы региональной диагностики. В частности, А. Г. Гранберг [2004, с. 109] в учебнике «Основы региональной экономики», указывал, что «....методология полной экономической диагностики довольно сложна и пока еще не стандартизирована». Рассматривая сущность, предмет и метод региональной диагностики, В. Н. Лексин [2003, с. 85] отмечал, что «...нникаких единых или общеобязательных методик ее проведения (и правил практического использования результатов) до сих пор не существует». Автор дал достаточно широкое определение метода региональной диагностики 
как соединения «...системного подхода (как общей исходной методологической установки) с различными методическими приемами, апробированными в различных областях прикладной информатики, экономики, социологии и других дисциплин» [Лексин, 2003, c. 71].

Дальнейшее совершенствование методического инструментария региональной диагностики требовало глубокой проработки ее методологических основ.

Весомый вклад в формирование теоретико-методологических положений диагностики региональных систем внесла уральская школа региональных исследований. Научным коллективом Института экономики Уральского отделения Российской академии наук (ИЭ УрО РАН) был разработан общий методический подход к диагностированию экономической безопасности в условиях кризисных явлений в мировой экономике [Социально-экономические риски..., 2010, с. 47], в том числе предложена общая схема диагностического анализа, отражающая основные функции диагностики. Учитывая различный характер целей региональной диагностики, авторы методики выделяют два типа диагностических исследований: экспресс-диагностику и глубокий диагностический анализ.

Системный подход к региональной диагностике нашел свое выражение в комплексной методике оценки качества жизни населения региона, разработанной авторским коллективом Центра экономической безопасности ИЭ УрО РАН [Социально-экономические риски..., 2010, с. 1017-1030]. Полагаем, что важным достижением ученых уральской школы является детальная разработка универсальной технологии проведения региональной диагностики, которая может применяться независимо от уровня территориальной системы и особенностей предмета исследования.

В рамках парадигмы регионального саморазвития, разрабатываемой сотрудниками ИЭ УрО РАН, в качестве обязательного элемента системного анализа региональной системы указан кризисный анализ, построенный на типологии территориальных структур на основе диагностики устойчивости их развития, наличия источников саморазвития и адаптационных способностей [Татаркин, 2011, с. 41]. В соответствии с данным подходом разработана методика диагностики безопасности саморазвивающейся социальноэкономической системы, основанная на многокритериальных оценках [Татаркин и др., 1997; Татаркин, 2011, с. 220], и методика оценки потенциала саморазвития региональных социально-экономических подсистем, функционирующих на территории субъекта Российской Федерации [Татаркин, 2011, с. 176-180].

За годы своего развития региональная наука сформировала мощный аппарат методов региональных исследований, которые могут использоваться для диагностики. Развернутую классификацию методов и инструментов региональной экономики представил А. Г. Гранберг [2004, с. 82]. Как правило, структурирование пространства методов осуществляется на основе результатов опыта эмпирических исследований путем привязки конкретных моделей к типовым задачам, которые уже были решены с их помощью. Типичной является следующая классификация методов [Решиев, Даурбеков, 2012, с. 82]:

- экономические (сравнение, группировка, балансовый, графический);

- статистические (использование средних и относительных величин, индексный метод, корреляционный и регрессионный анализ);

- математические (матричные, теория производственных функций, теория межотраслевого баланса);

- экономической кибернетики и математического программирования (линейное, нелинейное, динамическое программирование);

- исследования операций и принятия решений (теория графов, теория игр, теория массового обслуживания). 
На основе анализа научных трудов, посвященных диагностике, автором была предложена классификация, в которой представлены следующие методы региональной диагностики:

- математическая статистика;

- рейтинговые оценки на основе индексного подхода;

- модифицированные модели экономического роста и пространственная эконометрика;

- структуризация пространства индикаторов в виде региональных кластеров;

- измерения центропериферийных различий;

- математическое моделирование и оптимизация.

Сравнительный анализ методов проведен ранее [Юдина, 2016, с. 86-98]. Полагаем, что процесс формирования методической базы региональной диагностики далек от завершения, но находится в активной фазе поиска и апробации новых инструментов. Масштабность этого процесса требует выделения отдельного направления региональной диагностики - исследовательской диагностики (метадиагностики), занимающейся вопросами развития теоретической и инструментальной базы диагностических исследований.

\section{Роль региональной диагностики \\ в процессах стратегического планирования и прогнозирования}

Изучение состояния региональной системы любого ранга, причинно-следственных связей ее функционирования с целью обнаружения отклонений от нормального процесса развития и разработки соответствующих управленческих воздействий осуществляется с помощью региональной диагностики. Региональная диагностика должна являться как базовым блоком системы стратегического планирования и прогнозирования, так и инструментом мониторинга для получения информации о ходе реализации планов и программ.

Поскольку региональные системы обладают всеми признаками саморазвивающихся социально-экономических систем, то, по нашему мнению, наиболее полно отражает все закономерности регионального развития теория региональных саморазвивающихся социально-экономических систем, базирующаяся на системно-синергетической методологии, которую активно разрабатывают представители уральской региональной школы. Раскрывая теоретические положения методики диагностики безопасности саморазвивающейся системы, ученые акцентируют внимание на том, что одной из важнейших проблем теории саморазвивающихся социально-экономических систем, которую призвана решить диагностика, становится выявление граничных условий, при которых указанные системы не утрачивают «...качественной определенности» и продолжают функционировать в режиме «нормального риска» [Татаркин, 2011, с. 209].

Полагаем, что адекватным методологии системно-синергетической парадигмы и теории саморазвивающихся региональных систем является кибернетический подход к трактовке региональной диагностики. Согласно этому подходу, региональная диагностика представляет собой постоянно действующую подсистему механизма саморегуляции и саморазвития региональной социально-экономической системы. Следовательно, основная функция региональной диагностики - обеспечение обратной связи путем формирования, фильтрации и структурирования информации для разработки, принятия и оценки эффективности решений по управлению региональным развитием.

Изложенная трактовка сущности региональной диагностики с точки зрения кибернетического подхода означает, что и региональная диагностика является саморазвивающейся подсистемой субъекта управления регионом. Данная подсистема должна 
содержать два взаимосвязанных уровня: основной и вспомогательный. Основной уровень - прикладная региональная диагностика, нацеленная на выполнение задач информационно-диагностического обеспечения субъекта управления регионом. Вспомогательный уровень - исследовательская диагностика (метадиагностика).

Диагностическое исследование больших региональных систем целесообразно начинать с фазы предварительной диагностики (экспресс-диагностики), на которой проводится оперативное изучение объекта, делается общий вывод о его состоянии, выявляются ключевые проблемы. Роль данной фазы очень важна, так как позволяет выстроить правильный вектор дальнейших этапов диагностического исследования.

В соответствии со структурным подходом философской теории развития структура выступает как основная категория, поскольку процесс развития трактуется как качественные изменения в структуре объекта (возникновение новых элементов, связей, зависимостей) [Татаркин, 2011, с. 126]. Региональные социально-экономические системы способны изменять структуру и систему взаимосвязей под воздействием внешних и внутренних факторов [Татаркин, 2011, с. 31]. В соответствии с системно-синергетическим подходом этапы развития сложной системы отражаются в свойствах ее структуры [Форрестер, 2012].

Исследованием структурных свойств сложных региональных систем занимается структурная диагностика, основанная на декомпозиции изучаемого объекта, выявлении пропорций и взаимосвязей. Структурная диагностика предполагает использование специального методического инструментария. На предварительной фазе диагностики наиболее эффективны компактные модели структурной диагностики, которые позволяют диагностировать устойчивые различия в уровнях развития отдельных элементов региональной системы и обладают высокой чувствительностью к выявлению существенных трансформаций, происходящих в системе.

\section{Описание комплекса методов для предварительной фазы структурной диагностики макрорегиональных систем}

Стратегия пространственного развития выделяет макрорегиональный уровень как основной объект перспективных инвестиционных проектов и программ, что ставит перед метадиагностикой новые задачи по актуализации методических подходов к диагностике.

Необходимо отметить, что в Прогнозе социально-экономического развития Российской Федерации на 2016-2018 гг. ${ }^{1}$ агрегирование основных макроэкономических параметров представлено на двух уровнях: федеральных округов и субъектов Федерации. В последующих прогнозных документах макрорегиональный уровень был опущен, оставлен только уровень регионов - субъектов РФ.

Поскольку сбор и группировка данных в разрезе выделяемых Стратегией пространственного развития 14 макрорегионов официальной статистикой пока не производятся, апробируем комплекс методов структурной диагностики на примере макрорегионов федеральных округов. В качестве объекта моделирования представим Российскую Федерацию как региональную систему, состоящую из макрорегионов - федеральных округов.

В качестве исходных данных будем рассматривать следующие структурные параметры (табл. 1).

Параметр 1 - доля федерального округа в общем объеме инвестиций в основной капитал. Показатели рассчитаны по официальным статистическим данным: инвестиции в основной капитал по субъектам Российской Федерации в январе-декабре 2015 г.;

\footnotetext{
${ }^{1}$ Официальный сайт Министерства экономического развития России. URL: http://www.economy.gov.ru
} 
Таблица 1. Исходные параметры диагностики по федеральным округам в 2015-2017 гг., \% Table 1. Input parameters of federal districts in 2015-2017, \%

\begin{tabular}{|l|r|r|r|r|r|r|r|r|r|}
\hline \multirow{2}{*}{ Федеральный округ } & \multicolumn{3}{|c|}{ Параметр 1 } & \multicolumn{3}{c|}{ Параметр 2 } & \multicolumn{3}{c|}{ Параметр 3 } \\
\cline { 2 - 11 } & \multicolumn{2}{|c|}{$\begin{array}{c}\text { Доля в общем объеме } \\
\text { инвестиций в основной }\end{array}$} & \multicolumn{3}{c|}{$\begin{array}{c}\text { Доля в валовом } \\
\text { региональном продукте }\end{array}$} & \multicolumn{3}{c|}{$\begin{array}{c}\text { Доля в общей } \\
\text { численности населения }\end{array}$} \\
\cline { 2 - 12 } & 2015 & 2016 & 2017 & 2015 & 2016 & 2017 & 2015 & 2016 & 2017 \\
\hline Центральный & 26,06 & 26,00 & 26,13 & 34,86 & 34,40 & 34,60 & 26,68 & 26,70 & 26,73 \\
\hline Южный & 8,83 & 7,60 & 8,75 & 7,04 & 7,10 & 7,30 & 11,17 & 11,18 & 11,19 \\
\hline Северо-Кавказский & 3,60 & 3,32 & 3,16 & 2,62 & 2,70 & 2,70 & 6,63 & 6,64 & 6,67 \\
\hline Приволжский & 17,37 & 16,63 & 15,11 & 15,21 & 15,60 & 15,50 & 0,25 & 20,22 & 20,15 \\
\hline Уральский & 17,84 & 18,71 & 17,98 & 13,78 & 13,60 & 13,30 & 8,40 & 8,40 & 8,41 \\
\hline Сибирский & 9,81 & 9,62 & 9,53 & 10,36 & 10,70 & 10,60 & 13,19 & 13,18 & 13,15 \\
\hline Дальневосточный & 6,28 & 6,75 & 7,62 & 5,71 & 5,70 & 5,80 & 4,23 & 4,22 & 4,20 \\
\hline
\end{tabular}

инвестиции в основной капитал по субъектам Российской Федерации в январе-декабре 2016 г;; инвестиции в основной капитал по субъектам Российской Федерации в январедекабре 2017 г.

Параметр 2 - доля федерального округа в валовом региональном продукте. Показатели за 2015 и 2016 гг. рассчитаны по официальным статистическим данным: валовой региональный продукт по субъектам Российской Федерации в 1998-2016 гг.; за 2017 г. взяты значения из Прогноза социально-экономического развития Российской Федерации на 2016 год и плановый период 2017 и 2018 годов.

Параметр 3 - доля федерального округа в общей численности населения. Показатели рассчитаны по официальным статистическим данным: предварительная оценка численности постоянного населения на 1 января 2016 г. и в среднем за 2015 г.; предварительная оценка численности постоянного населения на 1 января 2017 г. и в среднем за 2016 г.; оценка численности постоянного населения на 1 января 2018 г. и в среднем за 2017 г. В табл. 1 спользованы данные в среднем за соответствующие годы.

Формирование оптимального набора параметров является важным вопросом любого диагностического исследования. При отборе учитываются такие критерии, как особенности объекта моделирования, цели, задачи исследования, применяемые методы диагностики, наличие достоверной информации.

Параметры, рассматриваемые в данном исследовании, представляются достаточно традиционными для научных работ, посвященных анализу макрорегиональных систем. В частности, эксперты Центра проблемного анализа и государственно-управленческого проектирования отмечают, что при диагностике региональных различий объективными основаниями выбора параметров являются: способность отражать уровень регионального развития (валовой региональный продукт на душу населения) и возможность влиять на его значение тми или иными инструментами государственной региональной политики (инвестиции в основной капитал на душу населения). Результаты проведенного экспертами исследования показали наличие взаимозависимости между указанными параметрами, т. е. одной из ключевых причин сложившихся различий в уровне развития регионов является нехватка инвестиционных ресурсов. Следовательно, «...для опережающего развития отдельных регионов нужно создать стимул для перетока капиталов и людей в этот регион» [Региональное измерение государственной..., 2007, с. 12-14, 18-19, 122]. 
В работах ученых ИЭиОПП СО РАН при проведении исследований межрегиональных сравнений на основе рейтинговых схем приоритет отдается показателям, основанным на ВРП, численности населения и инвестициях в основной капитал. В частности, в методике межрегиональных сопоставлений по макрорегионам РФ используются следующие методики расчета сводных рейтингов регионов: ДушВРП - душевой произведенный ВРП региона в \% к среднедушевому ВРП по РФ; ВесИнд - средняя оценка доли региона в РФ, нормированная к доли численности населения [Оптимизация территориальных систем, 2010, с. 54-55].

Ученые сибирской школы отмечают, что «...традиционным подходом к оценке уровня развития того или иного региона является обычно сравнительный анализ основных макропоказателей его развития с аналогичными данными в целом по стране». При этом в качестве основных критериев принято использовать показатели территориальной структуры произведенного ВРП, численности населения, использования ВРП на нужды накопления и потребления (в том числе, территориальная структура инвестиций в основной капитал) [Оптимизация территориальных систем, 2010, с. 136-139].

Таким образом, выбранные в данном исследовании параметры признаются ученымирегионалистами в качестве важнейших макроиндикаторов, отражающих как уровень развития региона, так и результативность мер государственной региональной политики. Необходимо также отметить, что приведенный выше набор параметров рассматривается как минимально употребимый для апробации методов экспресс-диагностики и выявления их эвристических возможностей. В дальнейшем это предполагает изменение и расширения количества используемых показателей.

Учитывая сложный характер объектов, целей и задач региональной диагностики, полагаем, что для проведения диагностических исследований целесообразно формировать комплекс из различных методов, в том числе с использованием экономико-математического моделирования. Каждый отдельный метод характеризуется определенными ограничениями, комплексный подход позволит получить более полную диагностическую картину объекта.

Изучение особенностей различных методов региональной диагностики, проведенное автором ранее [Юдина, 2016, с. 86-98], позволяет предложить комплекс методов в соответствии с требованиям предварительной фазы диагностики.

Полагаем, что в качестве первого этапа целесообразно применение методов математической статистики, в частности таких, как интегральные показатели структурных различий. Результаты расчетов представят общую оценку существенности структурных изменений в системе в целом. Ограничением данных методов является невозможность выявить изменения во взаимосвязях между подсистемами, поэтому на втором этапе используется методика группировки регионов в зависимости от характера структурных соотношений между параметрами. Выявление динамики структурных соотношений позволит оценить тенденции, намечающиеся в воспроизводственном процессе макрорегионов. Третий этап предполагает построение структурных индикаторов на основе математического аппарата теории графов и проведение на их основе оценки как общих свойств макрорегиональной системы, так и изменений структурных соотношений между региональными подсистемами по всему комплексу параметров.

\section{Комплекс методов для предварительной фазы структурной диагностики макрорегиональных систем}

Рассмотрим интегральные показатели структурных различий:

коэффициент относительных структурных сдвигов 


$$
L_{\text {отн }}=\frac{1}{n} \sum_{i=1}^{n} \frac{\left|d_{2 i}-d_{1 i}\right|}{d_{1 i}} ;
$$

интегральный коэффициент структурных различий В. М. Рябцева

$$
I_{R}=\sqrt{\frac{\sum_{i=1}^{n}\left(d_{2 i}-d_{1 i}\right)^{2}}{\sum_{i=1}^{n}\left(d_{2 i}+d_{1 i}\right)^{2}}},
$$

где $d_{1 i}$ и $d_{2 i}$ - удельные значения градаций двух структур; $i$ - элемент структуры; $n$ - число градаций.

Для характеристики меры различий структур будем использовать шкалу оценки меры существенности различий [Региональная статистика ..., 2001].

Качественный анализ динамики структурных соотношений между параметрами. Суть методики заключается в определении множества возможных соотношений между исследуемыми параметрами. При этом каждый тип соотношений может быть интерпретирован с точки зрения тенденций в воспроизводственном процессе региона, поскольку между ВРП, численностью населения и объемом инвестиций существует тесная зависимость, обусловленная прямыми и обратными связями [Региональное измерение государственной ..., 2007]. Возможные тенденции в воспроизводственном процессе региона, соответствующие типу соотношения между параметрами, представлены в табл. 2.

Анализ структурных соотношений по федеральным округам за 2015 г. и соответствующая типологизация макрорегиональных систем были проведены автором ранее [Юдина, 2018]. В данном исследовании необходимо было распределить макрорегионы по типам структурных соотношений данных за 2016 и 2017 гг, а также выявить произошедшие изменения.

Мультипараметрическая структурная диагностика на основе построения теоретико-графовой модели макрорегиональной системы. Для мультипараметрической структурной диагностики применим теоретико-графовую модель региональной системы. Теоретико-графовая модель строится на основе адаптации методики, разработанной и апробированной автором ранее [Юдина, 2016]. Основой методики послужили классические положения теории графов [Зыков, 2004].

Построение теоретико-графовой модели региональной системы Российской Федерации (в разрезе федеральных округов) осуществляется по мультипараметрическому комплексу «Структурные макроиндикаторы». Объектами моделирования являются федеральные округа Российской Федерации (макрорегионы), которым присваиваются номера $i=1, \ldots, n$. Каждому федеральному округу с номером $i$ ставится в соответствие вершина графа $v_{i}$. На основе исходной информации по мультипараметрическому комплексу «Структурные макроиндикаторы», представленной в табл.1, формируется матрица исходных данных за анализируемые периоды: $A=\left\{a_{j}^{i}\right\} i=1, \ldots, n, j=1, \ldots, m$, в которой $a_{j}^{i}$ - значение $j$-го параметра для $i$-го федерального округа.

Для построения дуг графа, отражающих мультипараметрические отношения, по каждой паре макрорегионов производится сравнение параметров. На основе обобщения результатов сравнения по отдельным параметрам делается вывод о характере отношений между вершинами.

Пусть $s$ и $k$ - произвольные макрорегионы, $s \neq k$. Считается, что макрорегион $s$ доминирует над макрорегионом $k$ по мультипараметрическому комплексу, если хотя бы одно значение параметра, соответствующее вершине $s$, больше значения соответствующего 


\section{Таблица 2. Классификация макрорегионов}

на основе типа структурных соотношений между параметрами

Table 2. Classification of macroregions based on the type of structural relationships between the parameters

\begin{tabular}{|c|c|c|}
\hline Тип соотношения & $\begin{array}{c}\text { Тенденции в воспроизводственном } \\
\text { процессе макрорегиона }\end{array}$ & $\begin{array}{c}\text { Группа } \\
\text { макрорегионов }\end{array}$ \\
\hline $\begin{array}{l}\text { Д }_{\text {и }}>Д_{\text {врп }}>Д_{\mathrm{H}} \\
\text { Доля инвестиций в основной ка- } \\
\text { питал превышает долю в совокуп- } \\
\text { ном ВРП, которая больше доли в } \\
\text { численности населения }\end{array}$ & $\begin{array}{l}\text { Ориентация на расширенное воспроиз- } \\
\text { водство: данный макрорегион «перетя- } \\
\text { гивает на себя» поток инвестиций, что } \\
\text { обеспечивает более высокий темп роста } \\
\text { ВРП }\end{array}$ & Развивающиеся \\
\hline $\begin{array}{l}Д_{и}>Д_{\text {врп }}<Д_{н} \\
\text { Доля инвестиций в основной ка- } \\
\text { питал больше доли в совокупном } \\
\text { ВРП, которая меньше доли в чи- } \\
\text { сленности населения }\end{array}$ & $\begin{array}{l}\text { Ориентация на расширенное воспроиз- } \\
\text { водство: макрорегион пока производит } \\
\text { меньше, чем возможно при его числен- } \\
\text { ности населения, но интенсивный поток } \\
\text { инвестиций создает благоприятный по- } \\
\text { тенциал для будущего роста ВРП }\end{array}$ & $\begin{array}{c}\text { Накапливающие } \\
\text { потенциал }\end{array}$ \\
\hline $\begin{array}{l}Д_{и}=Д_{\text {врп }}=Д_{\mathrm{H}} \\
\text { Доля инвестиций в основной ка- } \\
\text { питал отклоняется от доли в сово- } \\
\text { купном ВРП и доли в численности } \\
\text { населения не более чем на } 1 \text { п. п. }\end{array}$ & $\begin{array}{l}\text { Ориентация на простое воспроизводство: } \\
\text { макрорегион инвестирует в свое разви- } \\
\text { тие прямо пропорционально ВРП и чи- } \\
\text { сленности населения }\end{array}$ & Ста \\
\hline $\begin{array}{l}Д_{и}<Д_{\text {врп }}>Д_{\text {н }} \\
\text { Доля инвестиций в основной ка- } \\
\text { питал меньше доли в совокупном } \\
\text { ВРП, которая больше доли в чи- } \\
\text { сленности населения }\end{array}$ & $\begin{array}{l}\text { Ориентация на простое воспроизводство: } \\
\text { несмотря на то, что население макрореги- } \\
\text { она производит пропорционально боль- } \\
\text { ший объем ВРП, недостаточный объем } \\
\text { инвестиций в будущем отрицательно по- } \\
\text { влияет на его развитие }\end{array}$ & $\begin{array}{c}\text { Расходующие } \\
\text { потенциал }\end{array}$ \\
\hline $\begin{array}{l}Д_{и}<Д_{\text {врп }}<Д_{\mathrm{H}} \\
\text { Доля инвестиций в основной ка- } \\
\text { питал меньше доли в совокупном } \\
\text { ВРП, которая меньше доли в чи- } \\
\text { сленности населения }\end{array}$ & $\mid \begin{array}{l}\text { Сужающееся воспроизводство: население } \\
\text { макрорегиона производит пропорцио- } \\
\text { нально меньший объем ВРП, при этом } \\
\text { приток инвестиций недостаточен для } \\
\text { увеличения объемов производства }\end{array}$ & $\begin{array}{c}\text { Находящиеся } \\
\text { в критической } \\
\text { ситуации }\end{array}$ \\
\hline
\end{tabular}

Обозначения к табл. 2, 6:

Д - доля макрорегиона в общем объеме инвестиций в основной капитал;

$Д_{\text {врп }}$ - доля макрорегиона в совокупном валовом региональном продукте;

$Д_{н}$ - доля макрорегиона в общей численности населения.

параметра вершины $k$, а остальные значения параметров вершины $s$ не меньше значений параметров вершины $k$. Если значения параметров $a_{j}^{s}$ и $a_{j}^{k}$ полностью совпадают, то уровень развития макрорегиона $s$ эквивалентен уровню развития макрорегиона $k$ по исследуемому мультипараметрическому комплексу. Если отношения доминирования или эквивалентности не выявлены, то дуга графа не устанавливается.

На основе результатов мультипараметрического сравнения строится ориентированный граф доминирования $G=(V, E)$, где $V=\left\{v_{1}, \ldots, v_{n}\right\}$ - множество вершин; $E=\left\{\left(v_{i}, v_{k}\right)\right\}, i, k=1, \ldots, n ;\{i \neq k\}-$ множество дуг графа.

Для диагностических выводов характеристики структурного индикатора - графа доминирования, отражающие такие свойства региональной системы, как упорядоченность, организованность, а также динамичность и равномерность развития ее элементов, оцениваются с помощью коэффициентов, предложенных автором [Юдина, 2016]. 
Степень упорядоченности, организованности диагностируемой макрорегиональной системы оценивается с помощью коэффициента связности графа $\mathrm{K}_{\mathrm{c}}$. Чем выше значение коэффициента связности, тем более устойчивым является состояние системы по исследуемым параметрам.

Коэффициент связности графа рассчитывается по формуле

$$
\mathrm{K}_{\mathrm{C}}=\frac{\mathrm{E}_{\text {факт }}}{\mathrm{E}_{\text {мaкс }}} \times 100 \%,
$$

где $\mathrm{E}_{\text {факт }}$ - фактическое количество связей между вершинами графа; $\mathrm{E}_{\text {макс }}$ - максимальное количество связей между вершинами графа.

Для определения степени динамичности элементов диагностируемой системы применим коэффициент мобильности элементов системы $\mathrm{K}_{\mathrm{м}}$, который определяется по формуле

$$
\mathrm{K}_{\mathrm{M}}=\frac{V_{m}}{V_{n}} \times 100 \%
$$

где $V_{m}$ - количество вершин графа, у которых изменилось соотношение степеней входа и выхода; $V_{n}$ - общее количество вершин графа.

Степень неравномерности развития исследуемых элементов макрорегиональной сис-

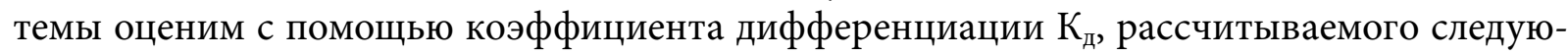
щим образом:

$$
\mathrm{K}_{\mathrm{д}}=\frac{U_{\text {фaxT }}}{V_{n}} \times 100 \%,
$$

где $U_{\text {факт }}$ - количество уровней графа; $V_{n}$ - количество вершин графа.

Высокие значения коэффициента мобильности отражают активные структурные трансформации, происходящие в системе.

Данная модель дает возможность многокритериального сравнения и группировки региональных подсистем на основе положения в графе доминирования. Доказано, что эвристическими свойствами модели являются, в частности, адаптивность к различным уровням объекта диагностики (региональной системы) и объему исходной информации [Юдина, 2016].

\section{Апробация комплекса методов предварительной фазы структурной диагностики макрорегиональных систем}

Расчет интегральных показателей структурных различий. Рассмотрим изменения структуры объемов инвестиций в основной капитал по макрорегионам в 2017 г. по сравнению с 2015 г. Согласно данным табл. 1, по итогам 2017 г. инвестиции перераспределились в пользу следующих федеральных округов: Центрального (ЦФО), Северо-Западного (СЗФО), Уральского (УрФО), Дальневосточного (ДВО). Следовательно, сократились доли инвестиций в Южном (ЮФО), Северо-Кавказском (СКФО), Приволжском (ПФО) и Сибирском (СФО) федеральных округах.

На основе интегральных показателей $L_{\text {отн }}$ и $I_{R}$ определим, насколько заметные структурные сдвиги произошли в сфере инвестирования в основной капитал, а также по другим исследуемым параметрам.

Необходимые промежуточные данные для расчета интегральных коэффициентов структурных сдвигов представлены в табл. 3-5. 
Таблица 3. Расчет интегральных показателей структурных сдвигов по доле в общем объеме инвестиций в основной капитал, 2017/2015 гг.

Table 3. Calculation of the integrated indicators of structural shifts in the share in total fixed investment in 2017/2015

\begin{tabular}{|l|c|c|c|c|c|}
\hline \multicolumn{1}{|c|}{ Федеральный округ } & $\left|d_{2017 i}-d_{2015 i}\right|$ & $\frac{\left|d_{2017 i}-d_{2015 i}\right|}{d_{2015 i}}$ & $\left(d_{2017 i}-d_{2015 i}\right)^{2}$ & $d_{2015 i}+d_{2017 i}$ & $\left(d_{2015 i}+d_{2017 i}\right)^{2}$ \\
\hline Центральный & 0,07 & 0,0027 & 0,0049 & 52,19 & 2723,7961 \\
\hline Северо-Западный & 1,51 & 0,1479 & 2,2801 & 21,93 & 480,9249 \\
\hline Южный & 0,08 & 0,0091 & 0,0064 & 17,58 & 309,0564 \\
\hline Северо-Кавказский & 0,44 & 0,1222 & 0,1936 & 6,76 & 45,6976 \\
\hline Приволжский & 2,26 & 0,1301 & 5,1076 & 32,48 & 1054,9504 \\
\hline Уральский & 0,14 & 0,0078 & 0,0196 & 35,82 & 1283,0724 \\
\hline Сибирский & 0,28 & 0,0285 & 0,0784 & 19,34 & 374,0356 \\
\hline Дальневосточный & 1,34 & 0,2134 & 1,7956 & 13,90 & 193,2100 \\
\hline \multicolumn{1}{r|}{ Итого } & - & 0,6617 & 9,4862 & - & 6464,7434 \\
\hline
\end{tabular}

Рассчитаем коэффициент относительных структурных сдвигов:

$$
L_{\text {отн }}=\frac{1}{8} \sum_{i=1}^{8} \frac{\left|d_{2017 i}-d_{2015 i}\right|}{d_{2015 i}}=\frac{1}{8} 0,6617=0,0827 .
$$

Результат говорит о том, что в среднем удельные веса федеральных округов отклонились за рассматриваемый период на 8,27 \%. Это свидетельствует о незначительном изменении структур.

Рассчитаем интегральный коэффициент структурных различий В. М. Рябцева:

$$
I_{R}=\sqrt{\frac{\sum_{i=1}^{8}\left(d_{2017 i}-d_{2015 i}\right)^{2}}{\sum_{i=1}^{8}\left(d_{2015 i}+d_{2017 i}\right)^{2}}}=\sqrt{\frac{9,4862}{6464,7434}}=0,0383 .
$$

Согласно шкале оценки меры существенности различий по коэффициенту В. М. Рябцева, интервал значений от 0,031 до 0,070 характеризует весьма низкий уровень различий структур.

\section{Таблица 4. Расчет интегральных показателей структурных сдвигов по доле в валовом региональном продукте, 2017/2015 гг.}

Table 4. Calculation of the integrated indicators of structural shifts in the share in gross regional product in 2017/2015

\begin{tabular}{|l|c|c|c|c|c|}
\hline \multicolumn{1}{|c|}{ Федеральный округ } & $\left|d_{2017 i}-d_{2015 i}\right|$ & $\frac{\left|d_{2017 i}-d_{2015 i}\right|}{d_{2015 i}}$ & $\left(d_{2017 i}-d_{2015 i}\right)^{2}$ & $d_{2015 i}+d_{2017 i}$ & $\left(d_{2015 i}+d_{2017 i}\right)^{2}$ \\
\hline Центральный & 0,26 & 0,0075 & 0,0676 & 69,46 & 4824,6916 \\
\hline Северо-Западный & 0,22 & 0,0211 & 0,0484 & 20,62 & 425,1844 \\
\hline Южный & 0,26 & 0,0369 & 0,0676 & 14,34 & 205,6356 \\
\hline Северо-Кавказский & 0,08 & 0,0305 & 0,0064 & 5,32 & 28,3024 \\
\hline Приволжский & 0,29 & 0,0191 & 0,0841 & 30,71 & 943,1041 \\
\hline Уральский & 0,48 & 0,0348 & 0,2304 & 27,08 & 733,3264 \\
\hline Сибирский & 0,24 & 0,0232 & 0,0576 & 20,96 & 439,3216 \\
\hline Дальневосточный & 0,09 & 0,0158 & 0,0081 & 11,51 & 132,4801 \\
\hline \multicolumn{1}{r|r|}{ Итого } & - & 0,1889 & 0,5702 & - & 7732,0462 \\
\hline
\end{tabular}


Определим коэффициент относительных структурных сдвигов по доле в валовом региональном продукте:

$$
L_{\text {отн }}=\frac{1}{8} \sum_{i=1}^{8} \frac{\left|d_{2017 i}-d_{2015 i}\right|}{d_{2015 i}}=\frac{1}{8} 0,1889=0,0236
$$

Следовательно, в среднем удельные веса федеральных округов отклонились за рассматриваемый период незначительно - на 2,36 \%.

Рассчитаем интегральный коэффициент структурных различий В. М. Рябцева:

$$
I_{R}=\sqrt{\frac{\sum_{i=1}^{8}\left(d_{2017 i}-d_{2015 i}\right)^{2}}{\sum_{i=1}^{8}\left(d_{2015 i}+d_{2017 i}\right)^{2}}}=\sqrt{\frac{0,5702}{7732,0462}}=0,0086 .
$$

По шкале оценки меры существенности различий по коэффициенту В. М. Рябцева интервал значений от 0,000 до 0,030 свидетельствует о тождественности структур.

\section{Таблица 5. Расчет интегральных показателей структурных сдвигов по доле в общей численности населения, 2017/2015 гг.}

Table 5. Calculation of the integrated indicators of structural shifts in the share in total population in 2017/2015

\begin{tabular}{|l|c|c|c|c|c|}
\hline \multicolumn{1}{|c|}{ Федеральный округ } & $\left|d_{2017 i}-d_{2015 i}\right|$ & $\frac{\left|d_{2017 i}-d_{2015 i}\right|}{d_{2015 i}}$ & $\left(d_{2017 i}-d_{2015 i}\right)^{2}$ & $d_{2015 i}+d_{2017 i}$ & $\left(d_{2015 i}+d_{2017 i}\right)^{2}$ \\
\hline Центральный & 0,05 & 0,0019 & 0,0025 & 53,41 & 2852,6281 \\
\hline Северо-Западный & 0,05 & 0,0053 & 0,0025 & 18,95 & 359,1025 \\
\hline Южный & 0,02 & 0,0018 & 0,0004 & 22,36 & 499,9696 \\
\hline Северо-Кавказский & 0,04 & 0,0060 & 0,0016 & 13,30 & 179,8900 \\
\hline Приволжский & 0,10 & 0,0049 & 0,0100 & 40,40 & 1632,1600 \\
\hline Уральский & 0,01 & 0,0012 & 0,0010 & 16,81 & 282,5761 \\
\hline Сибирский & 0,04 & 0,0030 & 0,0016 & 26,34 & 693,7956 \\
\hline Дальневосточный & 0,03 & 0,0071 & 0,0090 & 8,43 & 71,0649 \\
\hline \multicolumn{1}{r|}{ Итого } & - & 0,0312 & 0,0286 & - & 6571,1868 \\
\hline
\end{tabular}

Вычислим коэффициент относительных структурных сдвигов:

$$
L_{\text {отн }}=\frac{1}{8} \sum_{i=1}^{8} \frac{\left|d_{2017 i}-d_{2015 i}\right|}{d_{2015 i}}=\frac{1}{8} 0,0312=0,0039 .
$$

В среднем удельные веса федеральных округов в общей численности населения отклонились за рассматриваемый период на 0,39 \%.

Рассчитаем интегральный коэффициент структурных различий В. М. Рябцева:

$$
I_{R}=\sqrt{\frac{\sum_{i=1}^{8}\left(d_{2017 i}-d_{2015 i}\right)^{2}}{\sum_{i=1}^{8}\left(d_{2015 i}+d_{2017 i}\right)^{2}}}=\sqrt{\frac{0,0286}{6571,1868}}=0,0021 .
$$

Результат свидетельствует о тождественности анализируемых структур по параметру 3. 
Таким образом, рассчитанные значения интегральных показателей структурных сдвигов показывают, что структурных изменений в распределении производства валового продукта и численности населения по федеральным округам за рассматриваемый период не произошло. По структуре инвестиций в основной капитал значения коэффициентов выше, но характеристика «низкий уровень различия структур» не позволяет говорить о каких-то заметных трансформациях в системе. Следовательно, либо значимые признаки развития в системе отсутствуют, либо необходимо использовать методы диагностики с более высоким порогом чувствительности. Для получения дополнительных результатов диагностики применим качественно иной метод.

Качественный анализ динамики структурных соотночений между параметрами. На основе данных табл. 1 рассмотрим динамику структурных соотношений между параметрами. Изменения, произошедшие в составе групп регионов в 2016 и 2017 гг. по сравнению с 2015 г., обобщены в табл. 6.

\section{Таблица 6. Распределение макрорегионов Российской Федерации по типам структурных соотношений в 2015-2017 гг.}

Table 6. Distribution of Russia's macroregions by the type of structural relationships in 2015-2017

\begin{tabular}{|c|c|c|c|c|}
\hline \multirow{2}{*}{ Группа макрорегонов } & \multirow{2}{*}{$\begin{array}{c}\text { Тип и характеристика } \\
\text { соотношения }\end{array}$} & \multicolumn{3}{|c|}{ Федеральные округа } \\
\hline & & 2015 & 2016 & 2017 \\
\hline \multirow{3}{*}{$\begin{array}{l}\text { Развивающиеся (ориентация } \\
\text { на расширенное воспроизводство) }\end{array}$} & Д $_{и}>Д_{\text {врп }}>Д_{н}$ & УрФО & УрФО & УрФО \\
\hline & & ДВФО & ДВФО & ДВФО \\
\hline & & & СЗФО & СЗФО \\
\hline \multirow{3}{*}{$\begin{array}{l}\text { Накапливающие потенциал (ори- } \\
\text { ентация на расширенное воспро- } \\
\text { изводство) }\end{array}$} & Д $_{\mathrm{n}}>Д_{\mathrm{врп}}<Д_{\mathrm{H}}$ & ЮФО & ЮФО & ЮФО \\
\hline & & СКФО & СКФО & СКФО \\
\hline & & ПФО & ПФО & \\
\hline $\begin{array}{l}\text { Стабильные (ориентация на про- } \\
\text { стое воспроизводство) }\end{array}$ & $Д_{и}=Д_{\text {врп }}=Д_{н}$ & СЗФО & - & - \\
\hline $\begin{array}{l}\text { Расходующие потенциал (ориента- } \\
\text { ция на простое воспроизводство) }\end{array}$ & $\bar{Д}_{\mathrm{u}}<$ Дврп $_{\mathrm{B}}>$ Д $_{\mathrm{H}}$ & ЦФО & ЦФО & ЦФО \\
\hline $\begin{array}{l}\text { В критической ситуации (сужаю- } \\
\text { щееся воспроизводство) }\end{array}$ & Д $_{\text {и }}<Д_{\text {врп }}<Д_{\text {н }}$ & СФО & СФО & СФО ПФО \\
\hline
\end{tabular}

По итогам 2017 г. в Центральном федеральном округе незначительно увеличилась доля инвестиций (на 0,07 п.п.) и численности населения (на 0,05 п.п.), доля ВРП снизилась на 0,26 п.п., при этом структурные соотношения между параметрами остались неизменными.

Положительная динамика инвестиций, наблюдаемая в Северо-Западном федеральном округе в 2016-2017 гг. (108,3 \% и 104,5 \% соответственно), позволила повысить их долю в общем объеме на 1,51 п.п. и переместиться из группы регионов, ориентированных на простое воспроизводство, в группу развивающихся регионов (с ориентацией на расширенное воспроизводство).

Доли Южного федерального округа в общей численности населения и в ВРП постепенно растут (с 11,17 \% до 11,19 \% и с 7,04 \% и до 7,30 \% соответственно) благодаря положительной ежегодной динамике. Усиление концентрации инвестиций было обеспечено высоким приростом по итогам 2017 г. (на 16,4%). Достигнутый показатель является результатом реализации масштабных государственных инвестиционных проектов на территории Республики Крым: только за 2017 г. инвестиции в Крым выросли на 234,7 \%․

\footnotetext{
${ }^{1}$ Республика Крым в цифрах. 2017: кр. стат. сб. (2018). Крымстат-С.
} 
При этом по характеру соотношений между параметрами ЮФО пока остается в группе регионов, накапливающих потенциал.

По Северо-Кавказскому федеральному округу, несмотря на положительную динамику структурных показателей по численности населения и ВРП, наблюдается ежегодное уменьшение доли в общем объеме инвестиций (на 0,44 п.п. за 2016-2017 гг.). В результате СКФО по-прежнему занимает последнее место среди макрорегионов по доле инвестиций в основной капитал, хотя по данным за 2017 г. доля численности населения в этом округе $(6,67 \%)$ больше, чем в Дальневосточном $(4,2 \%)$, и сравнима с уровнем населенности Уральского федерального округа $(8,41 \%)$. При этом инвестиционная доля в Дальневосточном округе составляет 7,62 \%, что в 2,4 раза больше, чем в СКФО, а инвестиционная доля Уральского макрорегиона превышает долю СКФО в 4,9 раза.

Неблагоприятная ситуация наблюдается в самом населенном (после Центрального) Приволжском округе, где проживает более 20 \% населения РФ. По итогам 2017 г. это единственный макрорегион, демонстрирующий отрицательную динамику инвестиций в основной капитал $(96,1 \%$ к 2016 г.). Недостаточный приток инвестиций значительно снизил их долю (на 2,26 п.п.) и изменил соотношение между параметрами. В результате по итогам 2017 г. Приволжский федеральный округ переместился из группы регионов с ориентацией на расширенное воспроизводство в группу регионов, находящихся в критической ситуации.

Уральский федеральный округ сохраняет свою позицию в группе развивающихся макрорегионов. Как и в Северо-Западном округе, положительная динамика инвестиций в данном регионе, зафиксированная в 2016 г. (108,8 \%), сохранилась и по итогам 2017 г. $(103,2 \%)$.

В случае с Сибирским округом стабильность позиции (в группе регионов, находящихся в критической ситуации) является негативной. Несмотря на признаки положительной динамики (прирост инвестиций по итогам 2017 г. составил 100,3\%), доля инвестиций макрорегиона снизилась с 9,62 \% в 2016 г. до 9,53 \% в 2017 г., что не соответствует доле региона в численности населения, а также в участии формирования ВРП.

По итогам 2017 г. Дальневосточный федеральный округ является лидером по росту инвестиций в основной капитал $(117,1$ \%). Как отмечает Министерство Российской Федерации по развитию Дальнего Востока, достигнутый показатель - это один из результатов реализации государственной стратегии опережающего экономического развития Дальнего Востока. С 2015 г. инвестиционная доля округа выросла на 1,34 п.п. Макрорегион занимает устойчивое положение в группе развивающихся регионов.

Таким образом, несмотря на выводы о незначительном изменении структур, основанные на результатах расчетов интегральных показателей структурных различий, анализ соотношений структурных параметров выявил, что активизация потоков инвестиций, обусловленных стратегическими решениями государственного уровня, повлияла на структурные соотношения параметров и изменила воспроизводственные позиции ряда макрорегионов.

Мультипараметрическая структурная диагностика на основе построения теоретико-графовой модели макрорегиональной системы. Для построения дуг графа, отражающих мультипараметрические отношения, по каждой паре вершин графа (федеральным округам) произведем многокритериальное сравнение по всему комплексу параметров. Результаты многокритериального сравнения отражены в табл. 7, 9.

На рис. 1 представлен граф доминирования по мультипараметрическому комплексу «Структурные макроиндикаторы» за 2015 г. 


\section{Таблица 7. Мультипараметрические выводы о характере отношений между вершинами графа в 2015 г.}

Table 7. Multi-parameter conclusions about the nature of the relationships between graph vertices in 2015

\begin{tabular}{|c|c|c|c|c|c|c|c|c|}
\hline Федеральный округ & ЦФО & СЗФО & ЮФО & СКФО & $\Pi Ф О$ & УрФО & $\mathrm{CФO}$ & ДВФО \\
\hline Центральный & & $\mathrm{H}$ & $\mathrm{H}$ & $\mathrm{H}$ & $\mathrm{H}$ & $\mathrm{H}$ & $\mathrm{H}$ & $\mathrm{H}$ \\
\hline Северно-Западный & Д & & $\mathrm{X}$ & $\mathrm{H}$ & Д & $\mathrm{X}$ & Д & $\mathrm{H}$ \\
\hline Южный & Д & $\mathrm{X}$ & & $\mathrm{H}$ & Д & $\mathrm{X}$ & Д & $\mathrm{H}$ \\
\hline Северо-Кавказский & Д & Д & Д & & Д & Д & Д & $\mathrm{X}$ \\
\hline Приволжский & Д & $\mathrm{H}$ & $\mathrm{H}$ & $\mathrm{H}$ & & $\mathrm{H}$ & $\mathrm{H}$ & $\mathrm{H}$ \\
\hline Уральский & Д & $\mathrm{X}$ & $\mathrm{X}$ & $\mathrm{H}$ & Д & & $\mathrm{X}$ & $\mathrm{H}$ \\
\hline Сибирский & Д & $\mathrm{H}$ & $\mathrm{H}$ & $\mathrm{H}$ & Д & $\mathrm{X}$ & & $\mathrm{H}$ \\
\hline Дальневосточный & Д & Д & Д & $\mathrm{X}$ & Д & Д & Д & \\
\hline \multicolumn{9}{|c|}{ Мультипараметрические выводы о характере отношений между вершинами } \\
\hline Итого Д & $7 Д$ & $2 Д$ & $2 Д$ & - & $6 Д$ & $2 Д$ & 4Д & - \\
\hline $\mathrm{H}$ & - & $3 \mathrm{H}$ & $3 \mathrm{H}$ & $6 \mathrm{H}$ & $1 \mathrm{H}$ & $2 \mathrm{H}$ & $2 \mathrm{H}$ & $6 \mathrm{H}$ \\
\hline Э & - & - & - & - & - & - & - & - \\
\hline
\end{tabular}

Обозначения к табл. 7, 9:

Д - установлено отношение мультипараметрического доминирования между вершинами графа; $\mathrm{H}$ - установлено отношение мультипараметрического недоминирования между вершинами графа; $\mathrm{X}$ - отношения мультипараметрического доминирования/недоминирования не установлены; Э - установлено отношение эквивалентности между вершинами графа;

$\mathrm{E}_{\text {факт }}$ - фактическое количество связей;

$\mathrm{E}_{\text {макс }}$ - максимальное количество связей.

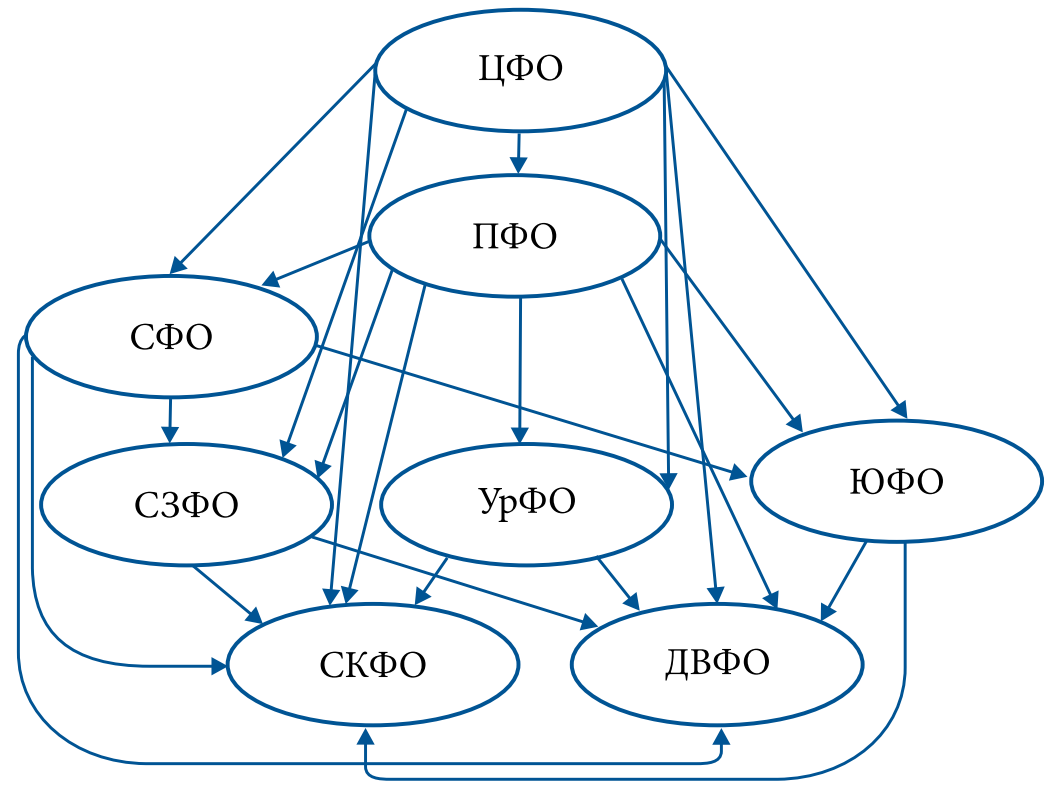

Рис. 1. Граф доминирования по макрорегиональной системе РФ (в разрезе федеральных округов) в 2015 г.

Fig. 1. Dominating set for Russia's macro-regional system (by federal districts) in 2015

Начальным этапом интерпретации результатов моделирования является анализ основных характеристик графа доминирования, таких как количество уровней, их насыщенность элементами, степень упорядоченности, симметричности и геометрическая форма. Исследуя в совокупности указанные параметры графа, можно сделать предположения об особенностях развития региональной системы - объекта моделирования. 
Анализ параметров полученного графа доминирования (см. рис. 1) показывает, что в 2015 г. структура макрорегиональной системы характеризовалась преобладанием вертикальных связей, а также вытянутой формой: восемь структурных элементов распределены по пяти уровням. Верхний и нижний уровни представлены незначительным числом элементов: безусловный лидер - ЦФО и конечные вершины - СКФО и ДВФО. Согласно классификации типов структур, предложенной автором ранее [Юдина, 2016, с. 128-129], данная форма свойственна упорядоченной сложной структуре, а именно ее ромбовидной («веретенообразной») разновидности. Такая форма свидетельствует о достаточно устойчивом социально-экономическом положении системы. При этом ограничения развития связаны с наличием стабильных аутсайдеров, к которым должны быть применены целевые методы региональной политики.

Идентификация типов вершин графа по соотношению степени выхода/входа позволяет распределить элементы региональной системы на классификационные группы, условно отражающие состояние социально-экономического развития по исследуемому мультипараметрическому комплексу. Результаты за 2015 г. представлены в табл. 8.

\section{Таблица 8. Классификация федеральных округов по мультипараметрическому комплексу в 2015 г.}

Table 8. Classification of federal districts according to the multi-parameter set in 2015

\begin{tabular}{|l|c|c|c|}
\hline $\begin{array}{c}\text { Федеральный округ } \\
\text { (вершины графа) }\end{array}$ & $\begin{array}{c}\text { Степени } \\
\text { выхода/входа }\end{array}$ & Тип вершины & $\begin{array}{c}\text { Тип элемента } \\
\text { региональной системы }\end{array}$ \\
\hline Центральный & $7 / 0$ & Пиковая & Лидер \\
\hline Приволжский & $6 / 1$ & Внутренняя поднимающаяся & Развивающийся \\
\hline Сибирский & $4 / 2$ & Внутренняя поднимающаяся & Развивающийся \\
\hline Уральский & $2 / 2$ & Внутренняя равновесная & Стабильный \\
\hline Северо-Западный & $2 / 3$ & Внутренняя нисходящая & Неустойчивый \\
\hline Южный & $2 / 3$ & Внутренняя нисходящая & Неустойчивый \\
\hline Северо-Кавказский & $0 / 6$ & Конечная & Отстающий \\
\hline Дальневосточный & $0 / 6$ & Конечная & Отстающий \\
\hline
\end{tabular}

В табл. 9 обобщены мультипараметрические выводы о характере отношений между вершинами графа по результатам многокритериального сравнения в 2017 г.

\section{Таблица 9. Мультипараметрические выводы о характере отношений между вершинами графа в 2017 г.}

Table 9. Multi-parameter conclusions about the nature of the relationships between graph vertices in 2017

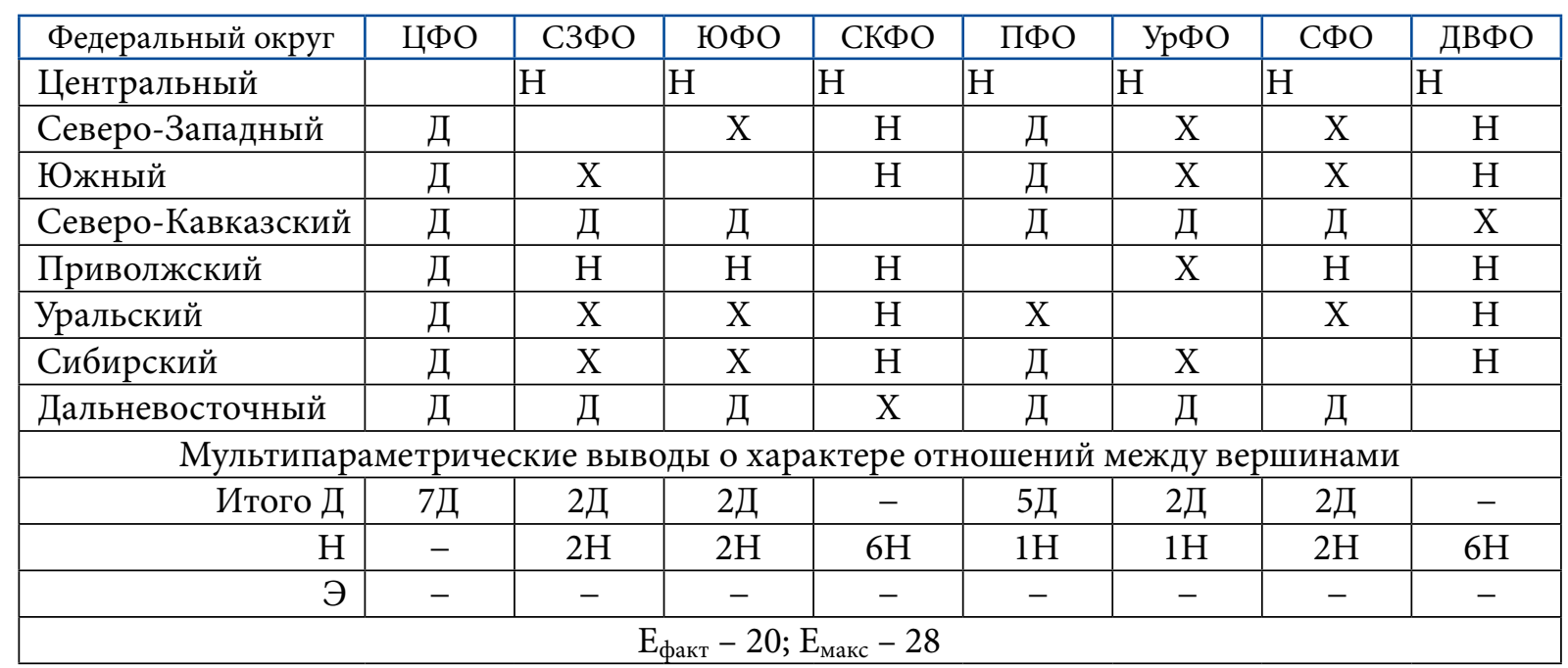


Граф доминирования, построенный по выявленным мультипараметрическим соотношениям в 2017 г. (рис. 2), сохранил ромбовидную форму. Это достаточно предсказуемо, так как структурные параметры больших социально-экономических систем характеризуются значительной степенью устойчивости, что позволяет их использовать в качестве индикаторов, чувствительных к действительно существенным изменениям в системе. Граф содержит четыре уровня, прежний состав лидеров и аутсайдеров. Тем не менее наблюдаются изменения на средних уровнях графа.

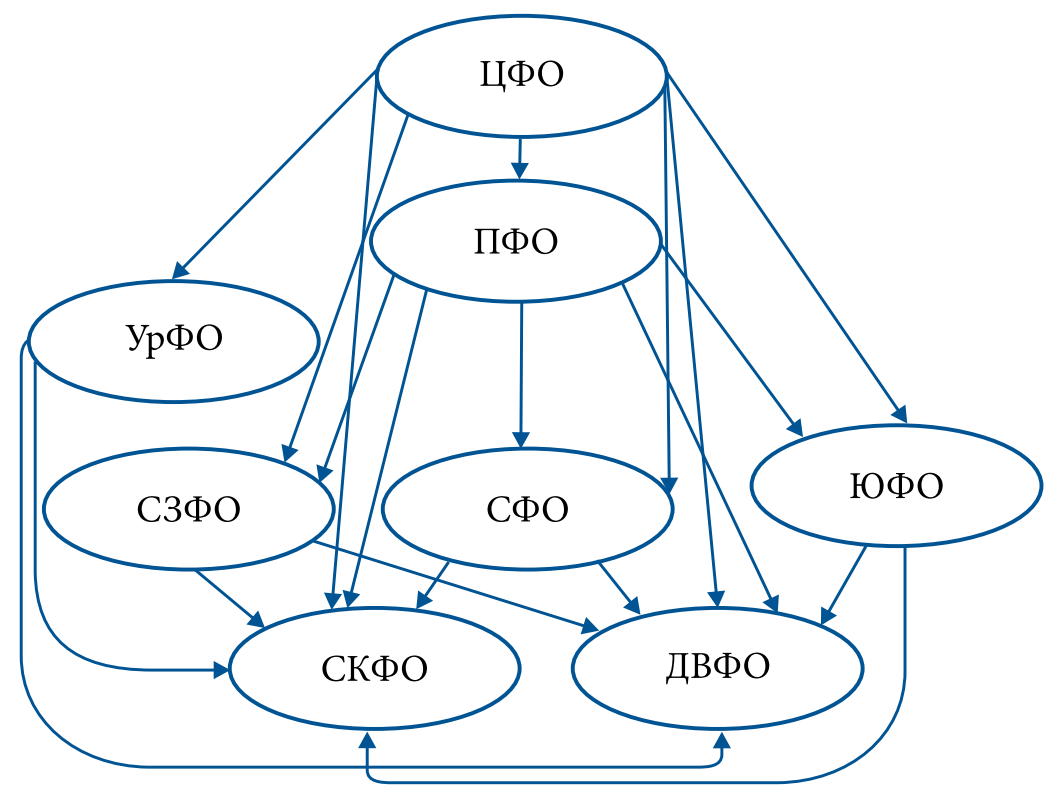

Рис. 2. Граф доминирования по макрорегиональной системе РФ (в разрезе федеральных округов) в 2017 г.

Fig. 2. Dominating set for Russia's macro-regional system (by federal districts) in 2017

Изменились степени выхода/входа у пяти элементов системы (табл. 10): ПФО сохранил свое положение как развивающийся, но потерял одну степень выхода (нет доминирования по УрФО); положительная динамика наблюдается по УрФО (переместился из стабильных в развивающиеся); СЗФО и ЮФО перешли с неустойчивой позиции на стабильную. С другой стороны, положение ухудшилось: потеряны две степени выхода (нет доминирования по СЗФО и ЮФО), уровень опустился из развивающихся в стабильные.

Таблица 10. Классификация федеральных округов

по мультипараметрическому комплексу в 2017 г.

Table 10. Classification of federal districts by the multi-parameter set in 2017

\begin{tabular}{|l|c|c|c|}
\hline $\begin{array}{c}\text { Федеральный округ } \\
\text { вершины графа) }\end{array}$ & $\begin{array}{c}\text { Степени } \\
\text { выхода/входа }\end{array}$ & Тип вершины & $\begin{array}{c}\text { Тип элемента } \\
\text { региональной системы }\end{array}$ \\
\hline Центральный & $7 / 0$ & Пиковая & Лидер \\
\hline Приволжский & $5 / 1$ & Внутренняя поднимающаяся & Развивающийся \\
\hline Уральский & $2 / 1$ & Внутренняя поднимающаяся & Развивающийся \\
\hline Сибирский & $2 / 2$ & Внутренняя равновесная & Стабильный \\
\hline Северо-Западный & $2 / 2$ & Внутренняя равновесная & Стабильный \\
\hline Южный & $2 / 2$ & Внутренняя равновесная & Стабильный \\
\hline Северо-Кавказский & $0 / 6$ & Конечная & Отстающий \\
\hline Дальневосточный & $0 / 6$ & Конечная & Отстающий \\
\hline
\end{tabular}


Результаты расчета коэффициентов оценки свойств исследуемой макрорегиональной системы представлены в табл. 11.

\section{Таблица 11. Оценка параметров структурного индикатора (графа доминирования)}

Table 11. Assessment of the structural indicator parameters (in the dominating set)

\begin{tabular}{|l|c|c|c|}
\hline \multirow{2}{*}{ Коэффициент } & Оцениваемые свойства & \multicolumn{2}{|c|}{ Полученные значения и их интерпретация } \\
\cline { 3 - 4 } & системы & 2015 & 2017 \\
\hline Связности графа К $\mathrm{K}_{\mathrm{c}}$ & Степень упорядоченности, & \multicolumn{2}{|c|}{ Высокий уровень организованности } \\
\cline { 3 - 4 } & организованности & $82,1 \%$ & $71,4 \%$ \\
& системы & & \\
\hline Мобильности & Степень динамичности & - & Высокий уровень \\
элементов системы $\mathrm{K}_{\mathrm{M}}$ & элементов системы & мобильности $62,5 \%$ \\
\hline Дифференциации $\mathrm{K}_{\text {д }}$ & Степень неравномерности & Высокий уровень & Средний уровень \\
& развития элементов & дифференциации & дифференциации \\
& системы & $62,5 \%$ & $50,0 \%$ \\
\hline
\end{tabular}

Высокий уровень организованности говорит о том, что исследуемая система устойчива, упорядочена. Уменьшение значения коэффициента связности (с 82,1 до 71,4 \%) свидетельствует об осторожных, но важных изменениях, происходящих в системе. Данную тенденцию подтверждает также достаточно высокий уровень мобильности (62,5 \%). Число активных элементов в системе доминирует, что отражает ее реакцию на изменившиеся условия, сигнализирует о предстоящих трансформациях в системе, поиске новых путей развития. Произошедшие за период исследования изменения в системе снизили уровень дифференциации с высокого (62,5 \%) до среднего уровня (50 \%).

\section{Заключение}

Диагностика макрорегиональных систем сопряжена с рядом объективных трудностей, наиболее существенными из которых являются необходимость обработки большого количества исходных данных и формирование комплекса диагностических методов для исследования широкого спектра направлений социально-экономического развития. Обязательным этапом диагностики макрорегиональных систем должна являться экспресс-диагностика, обладающая высоким уровнем чувствительности к значимым изменениям в системе и позволяющая задать нужный вектор последующим этапам диагностики.

Обобщая результаты исследования, можно сделать следующие выводы.

Проведение предварительной оценки на основе интегральных показателей структурных различий на первом этапе исследования не позволило выявить какие-либо значимые структурные сдвиги, а значит, и признаки развития в макрорегиональной системе за период исследования.

Качественный анализ соотношений между структурными параметрами на втором этапе исследования обнаружил изменения позиций отдельных макрорегионов, по которым в дальнейшем должно проводиться глубокое диагностическое исследование факторов и источников их развития. Получение такой первичной информации, определяющей приоритетные направления более детальных диагностических исследований, является основной функцией экспресс-диагностики и позволяет говорить о результативности применяемой методики на этом этапе.

Построение теоретико-графовой модели и выявление свойств системы на основе структурного индикатора - графа доминирования - на заключительном этапе исследования дали возможность оценить общие свойства макрорегиональной системы с точки зрения методологии системного подхода и теории региональных саморазвивающихся 
систем. На начало периода исследования (2015 г.) макрорегиональная система представляется избыточно упорядоченной, характеризующейся достаточно высоким уровнем различий между элементами (макрорегионами). По итогам 2017 г. наблюдается улучшение качественных характеристик системы: повышенная мобильность элементов снижает уровень организованности, система начинается постепенно трансформироваться, часть прежних связей исчезает, новые появляются медленно, но при этом по большинству элементов отмечаются положительные тенденции, уровень дифференциации снижается. Выявление структурных изменений в системе оценивается положительно, поскольку это говорит о ее развитии. Значимым свойством модели, на наш взгляд, является возможность исследования изменений положения вершин графа (макрорегионов) в графе доминирования. По выявленным изменениям можно определять приоритетные направления дальнейшей диагностики.

Апробация методов структурной диагностики выявила следующие эвристические возможности:

- граф доминирования позволяет получить компактную модель макрорегиональной системы, визуализировать результаты диагностики;

- сравнение макрорегиональных систем можно осуществлять одновременно по всему комплексу параметров;

- модель характеризуется адаптивностью к различному объему исходной информации, позволяет добавлять параметры, формировать новые мультипараметрические комплексы;

- методика на основе графа доминирования предполагает различные области применения: для диагностики исходного состояния макрорегиональной системы, на предплановой стадии для проработки сценариев развития при варьировании параметров, при проведении поисковых исследований оптимальной структуры.

В качестве практических направлений использования можно предложить следующие:

1. Применение мониторинга реализации Стратегии пространственного развития как одного из инструментов. Согласно Правилам осуществления мониторинга и контроля реализации Стратегии пространственного развития Российской Федерации, мониторинг возложен на Министерство экономического развития. Благодаря яркой визуализации и представлению в форме графа доминирования результаты экспресс-диагностики могут быть компактно представлены в федеральной информационной системе стратегического планирования.

2. Использование экспресс-диагностики при разработке региональных разделов ежегодных прогнозов социально-экономического развития Российской Федерации, а также долгосрочных прогнозов социально-экономического развития Российской Федерации. Результаты экспресс-диагностики будут критериями для определения приоритетных направлений глубоких диагностических исследований отдельных макрорегионов. При этом метод на основе графа доминирования может использоваться не только для диагностики исходного положения макрорегионов, но и моделирования будущих (в том числе вероятных и целевых) желаемых состояний макрорегиональной системы.

3. Программное решение методики на основе современных технологий имитационного моделирования обеспечивает оперативное расширение и обновление состава оцениваемых параметров; позволяет сформировать систему мультипараметрических комплексов по значимым сферам социально-экономического развития макрорегионов. Это открывает возможности ее применения в качестве инструмента информационно-аналитической поддержки процесса принятия управленческих решений по результатам мониторинга реализации документов стратегического планирования. 
Таким образом, использование методического инструментария структурной диагностики позволило выявить наметившиеся структурные сдвиги в макрорегиональной системе по мультипараметрическому комплексу исследуемых параметров и сделать выводы о достаточно высокой результативности применяемых методов.

\section{Источники}

Айзард У. (1966). Методы регионального анализа: введение в науку о регионах: пер. с англ. М.: Прогресс. 643 с.

Бухвальд Е. М., Валентик О. Н. (2018). Экономическое выравнивание регионов в стратегии пространственного развития для России // Вестник Владимирского государственного университета имени Александра Григорьевича и Николая Григорьевича Столетовых. Серия: Экономические науки. № 1 (15). С. 118-134.

Гранберг А. Г. (1965). Межотраслевые модели оптимального размещения производительных сил СССР // Модели и методы оптимального развития размещения производства: научные труды. Серия: Экономическая, вып. 3. Новосибирск: НГУ.

Гранберг А. Г. (2004). Основы региональной экономики : учебник для вузов; Государственный университет - Высшая школа экономики. 4-е изд. М.: Издательский дом ГУ - ВШЭ, 2004. 495 с.

Гранберг А. Г. (2007). Моделирование пространственного развития национальной и мировой экономики: эволюция подходов // Регион: экономика и социология. № 1. С. 87-106.

Гранберг А. Г., Суслов В. И., Суспицын С. А. (2007) Многорегиональные системы: экономикоматематическое исследование // СО РАН, ИЭОПП, Государственное НИУ «Совет по изучению производительных сил». Новосибирск : Сибирское научное издательство. 370 с.

Дмитриева О. Г. (1992). Региональная экономическая диагностика. СПб. : Изд-во Санкт-Петербургского университета экономики и финансов. $274 \mathrm{c}$.

Зыков А. А. (2004). Основы теории графов. М.: Вузовская книга. 664 с.

Лебединская Г. А. (2018). О месте стратегии пространственного развития в системе территориального планирования Российской Федерации // Academia. Архитектура и строительство. № 1. С. 59-66.

Лексин В. Н. (2003). Региональная диагностика: сущность, предмет и метод, специфика применения в современной России (вводная лекция предлагаемого учебного курса) // Российский экономический журнал. № 9-10. С. 64-86.

Оптимизация территориальных систем (2010) / под ред. С. А. Суспицына. Новосибирск: ИЭОПП СО РАН. $632 \mathrm{c}$.

Региональное измерение государственной экономической политики России (2007) / под общей ред. А. С. Малчинова; Центр проблемного анализа и государственно-управленческого проектирования. М.: Научный эксперт. 200 с.

Региональная статистика: учебник (2001) / под ред. В. М. Рябцева, Г. И. Чудилина. М.: МИД. 380 с.

Решиев С. С., Даурбеков С. С. (2012). Методы оценки характера и уровня развития региона // Журнал экономической теории. № 1. С. 78-88.

Рой О. М. (2018). Оптимизация межуровневого взаимодействия в условиях реализации пространственной политики России // Урал - XXI век: макрорегион неоиндустриального и инновационного развития: материалы III Международной научно-практической конференции: в 2 т. C. $47-53$.

Саморазвивающиеся социально-экономические системы: теория, методология, прогнозные оценки : в 2 т. (2011) / под общ. ред. А. И. Татаркина; Российская академия наук, Уральское отделение. М.: ЗАО «Издательство «Экономика»; Екатеринбург: УрО РАН. Т. 1. Теория и методология формирования саморазвивающихся социально-экономических систем. 308 с.

Саушкин Ю. Г. (1973). Экономическая география: история, теория, методы, практика. М.: Мысль. 559 с.

Силин Я. П., Анимица Е. Г., Новикова Н. В. (2017). Региональные аспекты новой индустриализации // Экономика региона. Т. 13, вып. 3. С. 684-696. 
Совершенствование теоретико-методологических основ формирования инновационной и финансовой стратегий развития территориальных систем разного уровня (2017) / под общ. ред. В. С. Бочко. Екатеринбург: Институт экономики УрО РАН, 2017. 203 с.

Социально-экономические риски: диагностика причин и прогнозные сценарии нейтрализации (2010) / под ред. В. А. Черешнева, А. И. Татаркина. Екатеринбург: Институт экономики УрО PAH. $1200 \mathrm{c}$.

Татаркин А. И., Куклин А. А., Романова О. А., Чуканов В. П., Козицын А. А. (1997). Экономическая безопасность региона: единство теории, методологии исследования и практики. Екатеринбург: Изд-во Урал. ун-та. 240 с.

Форрестер Дж. (2012). Мировая динамика. Письмо третье: от «системной модели» к структуродинамике. URL: http://www.metal-profi.ru/own/world-dynamics-12.htm

Шнипер Р. И. (1996). Регион: диагностика и прогнозирование: монография. Новосибирск: ИЭОПП СО РАН. 135 с.

Юдина М. А. (2016). Диагностика регионального развития: в поисках универсальной модели. Омск: Издательский центр КАН. 271 с.

Юдина М. А. (2018). Диагностика региональных различий в сфере инвестиционной деятельности // Проблемы теории и практики управления. № 1. С. 55-63.

\title{
Информация об авторе
}

Юдина Марина Александровна, кандидат экономических наук, доцент кафедры государственного, муниципального управления и таможенного дела Омского государственного технического университета, 644050, РФ, г. Омск, пр. Мира, 11

Контактный телефон: +7 (3812) 60-65-97, e-mail: myum@inbox.ru

Marina A. Yudina Omsk State Technical University, Omsk, Russia

\section{Methodological aspects of detecting macroregional structural shifts}

\begin{abstract}
Regulating inter-regional socioeconomic differentiation is one of the key tasks in strategic management of national spatial development. The paper explores the problem of the toolkit of regional diagnosis as one of the most important subsystems of strategic planning and forecasting. The study's objective is to develop the methods for diagnosing the differences in the condition of macroregional systems. The theory of regional self-developing socioeconomic systems based on the principles of the system-synergetic paradigm constitutes the methodological basis of the research. The method of the study consists of three stages: general assessment of structural shifts; analysis of the structural dynamics; design of a multi-parameter model for structural diagnosis. The use of indicative properties of the multi-parameter model allowed revealing the emergent structural shifts in the macroregional system according to a range of the involved parameters. The research findings for Russia as of 2017 demonstrated an improvement in qualitative characteristics of the macroregional system. The system is gradually changing, part of the previous relations ceases to exist, however, positive trends can be noticed and differentiation level is declining in the majority of macroregions. The application of the approach is
\end{abstract}


proved to be promising at the preliminary (diagnostic) stage of producing a regional component of the socioeconomic forecasts as well as for assessing the implementation results of the spatial development strategy.

Keywords: forecasting; system-synergetic approach; theory of regional self-developing systems; cybernetic approach; macroregional system; structural diagnosis; multi-parameter model; structural indicator.

For citation: Yudina M. A. Metodicheskie aspekty diagnostiki makroregional'nykh strukturnykh sdvigov [Methodological aspects of detecting macroregional structural shifts]. Journal of New Economy, 2019, vol. 20, no. 4, pp. 22-46. DOI: 10.29141/2073-1019-2019-20-4-2

Received March 25, 2019.

\section{References}

Isard W. (1966). Metody regional'nogo analiza: vvedenie v nauku o regionakh [Methods of regional analysis: An introduction to regional science]. Moscow: Progress Publ. 643 p. (in Russ.)

Bukhvald E. M., Valentik O. N. (2018). Ekonomicheskoe vyravnivanie regionov v strategii prostranstvennogo razvitiya dlya Rossii [Economic alignment of regions in the spatial development strategy for Russia]. Vestnik Vladimirskogo gosudarstvennogo universiteta imeni Aleksandra Grigoryevicha i Nikolaya Grigoryevicha Stoletovykh. Seriya: Ekonomicheskie nauki = Bulletin of Vladimir State University named after A.G. and N.G. Stoletovs. Series: Economic Sciences, no. 1 (15), pp. 118-134. (in Russ.)

Granberg A. G. (1965). Inter-industry models of the optimal distribution of the USSR productive forces. In: Modeli i metody optimal'nogo razvitiya razmeshcheniya proizvodstva: nauchnye trudy. Seriya: Ekonomicheskaya, vyp. 3 [Models and methods for the optimal development of the distribution of production: scientific works. Series: Economics, issue 3]. Novosibirsk: Novosibirsk State University. (in Russ.)

Granberg A. G. (2004). Osnovy regional'noy ekonomiki [Fundamentals of the regional economics]. Moscow: Higher School of Economics, 2004. 495 p. (in Russ.)

Granberg A. G. (2007). Modelirovanie prostranstvennogo razvitiya natsional'noy i mirovoy ekonomiki: evolyutsiya podkhodov [Modeling the spatial development of national and world economies: Evolution of approaches]. Region: ekonomika i sotsiologiya = Region: Economics and Sociology, no. 1, pp. 87-106. (in Russ.)

Granberg A. G., Suslov V. I., Suspitsyn S. A. (2007). Mnogoregional'nye sistemy: ekonomiko-matematicheskoe issledovanie [Multi-regional systems: Economic and mathematical research]. Novosibirsk: Sibirskoe nauchnoe izdatel'stvo Publ. 370 p. (in Russ.)

Dmitrieva O. G. (1992). Regional'naya ekonomicheskaya diagnostika [Regional economic diagnosis]. Saint Petersburg: Saint Petersburg State University of Economics and Finance. 274 p. (in Russ.)

Zykov A. A. (2004). Osnovy teorii grafov [Fundamentals of the graph theory]. Moscow: Vuzovskaya kniga Publ. 664 p. (in Russ.)

Lebedinskaya G. A. (2018). O meste strategii prostranstvennogo razvitiya v sisteme territorial'nogo planirovaniya rossiyskoy federatsii [On the place of the spatial development strategy in the territorial planning system of the Russian Federation]. Academia. Arkhitektura $i$ stroitelstvo = Academia. Architecture and construction, no. 1, pp. 59-66. (in Russ.)

Leksin V. N. (2003). Regional'naya diagnostika: sushchnost', predmet i metod, spetsifika primeneniya v sovremennoy Rossii (vvodnaya lektsiya predlagaemogo uchebnogo kursa) [Regional diagnosis: Essence, subject and method, specifics of application in modern Russia (introductory lecture of the proposed training course)]. Rossiyskiy ekonomicheskiy zhurnal = Russian Economic Journal, no. 9-10, pp. 64-86. (in Russ.)

Suspitsyn S. A. (ed.) (2010). Optimizatsiya territorial'nykh system [Optimization of territorial systems]. Novosibirsk: Institute of Economics and Industrial Engineering (Siberian branch of RAS). 632 p. (in Russ.) 
Malchinov A. S. (ed.) (2007). Regional'noe izmerenie gosudarstvennoy ekonomicheskoy politiki Rossii [Regional dimension of Russia’s state economic policy]. Moscow: Nauchnyy ekspert Publ. 200 p. (in Russ.)

Ryabtsev V. M., Chudilin G. I. (eds.) (2001). Regional'naya statistika [Regional statistics]. Moscow: MID Publ. 380 p. (in Russ.)

Reshiev S. S., Daurbekov S. S. (2012). Metody otsenki kharaktera i urovnya razvitiya regiona [Methods for assessing the nature and level of development of a region]. Zhurnal ekonomicheskoy teorii $=$ Russian Journal of Economic Theory, no. 1, pp. 78-88. (in Russ.)

Roy O. M. (2018). Optimization of inter-level interaction in the context of the implementation of the spatial policy of Russia. Materialy III Mezhdunarodnoy nauchno-prakticheskoy konferentsii "Ural - XXI vek: makroregion neoindustrial'nogo i innovatsionnogo razvitiya" [Proc. 3rd Int. Sci.-Prac. Conf. "Ural $-21^{\text {st }}$ Century: The Macroregion of the New Industrial And Innovative Development"]. pp. 47-53. (in Russ.)

Tatarkin A. I. (ed.) (2011). Samorazvivayushchiesya sotsial'no-ekonomicheskie sistemy: teoriya, metodologiya, prognoznye otsenki. T. 1. Teoriya i metodologiya formirovaniya samorazvivayushchikhsya sotsialno-ekonomicheskikh system [Self-developing socioeconomic systems: Theory, methodology, forecast. Vol. 1. Theory and methodology of formation of self-developing socioeconomic systems]. Moscow: Ekonomika Publ.; Ekaterinburg: Ural branch of RAS. 308 p. (in Russ.)

Saushkin Yu. G. (1973). Ekonomicheskaya geografiya: istoriya, teoriya, metody, praktika [Economic geography: History, theory, methods, practice]. Moscow: Mysl Publ. 559 p. (in Russ.)

Silin Ya. P., Animitsa E. G., Novikova N. V. (2017). Regional'nye aspekty novoy industrializatsii [Regional aspects of the new industrialization]. Ekonomika regiona $=$ Economy of Region, vol. 13, issue 3, pp. 684-696. (in Russ.)

Bochko V. S. (ed.) (2017). Sovershenstvovanie teoretiko-metodologicheskikh osnov formirovaniya innovatsionnoy i finansovoy strategiy razvitiya territorialnykh sistem raznogo urovnya [Improving the theoretical and methodological foundations of the formation of innovative and financial strategies for the development of territorial systems of different levels]. Ekaterinburg: Institute of Economics (Ural branch of RAS), 2017. 203 p. (in Russ.)

Chereshnev V. A., Tatarkin A. I. (eds.) (2010). Sotsial'no-ekonomicheskie riski: diagnostika prichin $i$ prognoznye stsenarii neytralizatsii [Socioeconomic risks: Diagnosis of causes and prognostic scenarios of neutralisation]. Ekaterinburg: Institute of Economics (Ural branch of RAS). 1200 p. (in Russ.)

Tatarkin A. I., Kuklin A. A., Romanova O. A., Chukanov V. P., Kozitsyn A. A. (1997). Ekonomicheskaya bezopasnost' regiona: edinstvo teorii, metodologii issledovaniya i praktiki [The economic security of a region: The unity of theory, research methodology, and practice]. Ekaterinburg: Ural University Publ. 240 p. (in Russ.)

Forrester J. (2012). Mirovaya dinamika. Pis'mo trete: ot "sistemnoy modeli" $k$ strukturodinamike [Global economic dynamics. The third letter: From the system model to structural dynamics]. Available at: http://www.metal-profi.ru/own/world-dynamics-12.htm (in Russ.)

Shniper R. I. (1996). Region: diagnostika i prognozirovanie [Region: Diagnosis and forecasting]. Novosibirsk: Institute of Economics and Industrial Engineering (Siberian branch of RAS). 135 p. (in Russ.)

Yudina M. A. (2016). Diagnostika regional'nogo razvitiya: $v$ poiskakh universal'noy modeli [Diagnosis of regional development: In search of a universal model]. Omsk: KAN Publ. 271 p. (in Russ.)

Yudina M. A. (2018). Diagnostika regional'nykh razlichiy v sfere investitsionnoy deyatel'nosti [Diagnosis of regional differences in the sphere of investment activities]. Problemy teorii i praktiki upravleniya $=$ The International Journal Theoretical and Practical Aspects of Management, no. 1, pp. 55-63. (in Russ.)

\section{Information about the author}

Marina A. Yudina, Cand. Sc. (Econ.), Associate Prof. of Public Administration, Municipal Governance and Customs Dept., Omsk State Technical University, 11 Mira Ave., Omsk, 644050, Russia

Phone: +7 (3812) 60-65-97, e-mail: myum@inbox.ru

(c) Юдина М. А., 2019 

Е. Б. Дворядкина Уральский государственный экономический университет, г. Екатеринбург, Российская Федерация

Д. М. Простова Уральский государственный экономический университет, г. Екатеринбург, Российская Федерация

\section{Некоммерческие организации в региональной экономике: теоретический подход к исследованию}

Аннотация. Обеспечение экономического роста регионов и муниципальных образований невозможно без становления «третьего сектора экономики», к которому относятся некоммерческие организации. Статья посвящена обоснованию целесообразности разработки нового теоретического подхода к исследованию функционирования и развития некоммерческих организаций в региональной экономике. Методологическая база исследования представлена совокупностью фундаментальных положений теории социального рыночного хозяйства, теории социоэкономики региона, парадигмы регионального управления. Современные исследования некоммерческих организаций в основном концентрируются на прикладных аспектах их функционирования, на вопросах их взаимодействия с органами государственной власти и местного самоуправления. Несмотря на большой массив достигнутных результатов в русле не только экономических, но и юридических, политических, социологических наук, наблюдается дефицит теоретико-методологических разработок, позволяющих сформировать концептуальный каркас исследования некоммерческих организаций в экономическом пространстве региона. Авторами статьи сформулирован ряд положений, позволяющих констатировать значимость изучения некоммерческих организаций в региональном экономическом пространстве в контурах трех основных теорий. Обобщение положений теории социального рыночного хозяйства позволило аргументировать значимость развития человеческого потенциала регионов и муниципальных образований на фоне процессов новой индустриализации. Наличие связей между экономикой и социумом в регионе доказано в рамках положений теории социоэкономики региона. Следовательно, некоммерческие организации можно интерпретировать как ресурс, необходимый для функционирования, развития социума, формирования и выражения его интересов. Интерпретация базовых положений парадигмы регионального управления позволила сделать вывод: задачей управления региональным социально-экономическим развитием является не только создание условий для повышения уровня жизни населения, но и формирование пропорций между элементами региональной социально-экономической системы, которые обеспечивали бы ее эффективность. Одним из них выступает некоммерческий сектор региональной экономики. Результаты работы могут составлять теоретический базис дальнейших исследований процессов функционирования и развития некоммерческих организаций в экономическом пространстве региона.

Ключевые слова: некоммерческая организация; регион; региональная экономика; теория социального рыночного хозяйства; теория социоэкономики региона; парадигма регионального управления. 
Для циттрования: Дворядкина Е. Б., Простова Д. М. Некоммерческие организации в региональной экономике: теоретический подход к исследованию // Journal of New Economy. 2019. T. 20, № 4. C. 47-69. DOI: 10.29141/2073-1019-2019-20-4-3

Дата поступления: 24 июня 2019 г.

\section{Введение}

$\mathrm{O}$ беспечение необходимых темпов экономического роста не представляется возможным без становления «третьего сектора экономики», к которому относятся некоммерческие организации, и его тесным взаимодействием с коммерческим, частным и государственными секторами в пространстве страны и региона. Некоммерческие организации как полноценные субъекты экономической деятельности становятся реальным экономическим фактором, влияющим на создание валовой добавленной стоимости, и, соответственно на экономический рост региона. Таким образом, существует потребность в построении эффективной модели функционирования и развития некоммерческого сектора экономики на федеральном, региональном и муниципальном уровнях.

В условиях нарастающих вызовов информационного, технологического, финансового, демографического характера, оказывающих влияние на формирование новой экономической повестки, в центре которой - экономический рост, исследование некоммерческих организаций приобретает все большую актуальность. Происходит формирование новых параметров экономического роста, составной частью которых являются индикаторы, характеризующие развитие гражданского общества как в стране в целом, так и в пространстве регионов и муниципальных образований.

Именно в рамках теории гражданского общества в зарубежной науке начинало происходить оформление теории некоммерческого сектора, что также было связано с появлением трехсекторной модели общества, представленной в работах А. Этциони [Etzioni, 1973], Т. Левитта [Levitt, 1973] и В. Нильсена [Nielsen, 1979]. Исследовательский интерес к гражданскому обществу, а следовательно, и к некоммерческому сектору был обусловлен усилением гражданского общества в распространении демократических принципов: М. Ховард [2009], Г. Бэйкер [Baker, 2002], Ф. Шмиттер [Schmitter, 1999], Дж. Кин [Keane, 2003], Г. Б. Мэдисон [Madison, 1998], М. Вальцер [Walzer, 1998] и др.

На фоне активного изучения некоммерческого сектора как компонента гражданского общества в политических науках, происходило также становление некоммерческого сектора в дискурсе экономических концепций человеческого капитала ([Becker, 1993]), социального капитала ([Olson, 1982; North, 1990; Putnam, 1995]).

Следует отметить, что некоммерческому сектору отводится главная роль в современной теории доверия [Putnam, 1995; Keane, 2003; Fukuyama, 1995; Seligman, 1997].

В ракурсе неоклассической экономической теории обосновывается роль рационального интереса граждан в создании некоммерческих организаций как производителей специфических благ и услуг. Поскольку рынку свойственно наличие проблемы «провала контракта», то именно некоммерческие организации способны снижать трансакционные издержки в таких условиях [Hansmann, 1987]. Основная цель деятельности коммерческих организаций, в отличие от некоммерческих, состоит в получении адекватного финансового результата, проблема «провала контракта» заключается в невозможности потребителя контролировать качественное предоставление социально значимых услуг, которые могут быть оказаны организациями, не заинтересованными в финансовой выгоде [Borgaza, Tortia, 2010]. Организации некоммерческого сектора нейтрализуют эту сложность, снижая издержки контроля посредством вовлечения граждан в свою деятельность. Следует согласиться с мнением А. Тарасенко [2015, с. 51] в том, что 
«...часть экономистов скептически настроена в отношении некоммерческого сектора, полагая, что НКО неэффективно используют ресурсы и производят услуги низкого качества. Исследователи, однако, склонны соглашаться в том, что третий сектор чрезвычайно разнообразен и включает в себя как профессиональные организации взаимопомощи, не претендующие на конкуренцию с государственными и коммерческими структурами».

Теория общественных благ постулирует положение о том, что развитие некоммерческих организаций связано с ограниченностью ресурсов и с тем, что органам власти и управления необходимо определять приоритеты государственной политики, ограничивая содержание «общего блага». Поскольку общество по своему составу гетерогенно, то удовлетворять все многообразие интересов представителей различных социальных групп сложно. Для удовлетворения такого нарастающего спроса создаются некоммерческие организации. При реализации государственной политики, правительство ориентируется на «среднего избирателя» [Weisbord, 1997].

Анализ экономической научной литературы позволяет сделать вывод о том, что институциональный подход является магистральным методологическим научным подходом к исследованию некоммерческих организаций, позволяя выстраивать алгоритмы исследования некоммерческих организаций на макроуровне. С позиций региональной экономики, обладающей пространственными особенностями и нацеленной на экономический рост не только в региональном, но и в локальном масштабе, целесообразно сформировать теоретическую платформу исследования некоммерческих организаций на основе триады теорий: социального рыночного хозяйства; социоэкономики региона; парадигмы регионального управления.

Цель статьи - обоснование нового теоретического подхода к исследованию некоммерческих организаций в региональной экономике, базирующийся на положениях теории социального рыночного хозяйства, теории социоэкономики региона и парадигмы регионального управления.

Поставленная цель предопределила задачи исследования:

- охарактеризовать основные положения теории социального рыночного хозяйства и обосновать их применимость к изучению некоммерческих организаций в региональной экономике;

- охарактеризовать основные положения теории социоэкономики региона и обосновать их применимость к анализу некоммерческих организаций в региональной экономике;

- сформулировать основные положения парадигмы регионального управления и адаптировать их для изучения некоммерческих организаций в региональной экономике;

- сформировать теоретическую схему на основе идентификации и адаптации основных положений теории социального рыночного хозяйства, социоэкономики региона и парадигмы регионального управления к исследованию процессов функционирования и развития некоммерческих организаций в региональной экономике.

\section{Теория социального рыночного хозяйства}

Во введении был обоснован тезис о том, что теоретической платформой исследования некоммерческих организаций в региональной экономике целесообразно считать синтез положений трех теорий: социального рыночного хозяйства; социоэкономики региона; парадигмы регионального управления (рис. 1).

Следует согласиться с мнением Н. И. Морозовой [2011, с. 65]: «...сегодня нельзя не видеть, что эволюция к социально ориентированной экономике становится общемировой тенденцией. Стратегией социального управления является движение к современным 


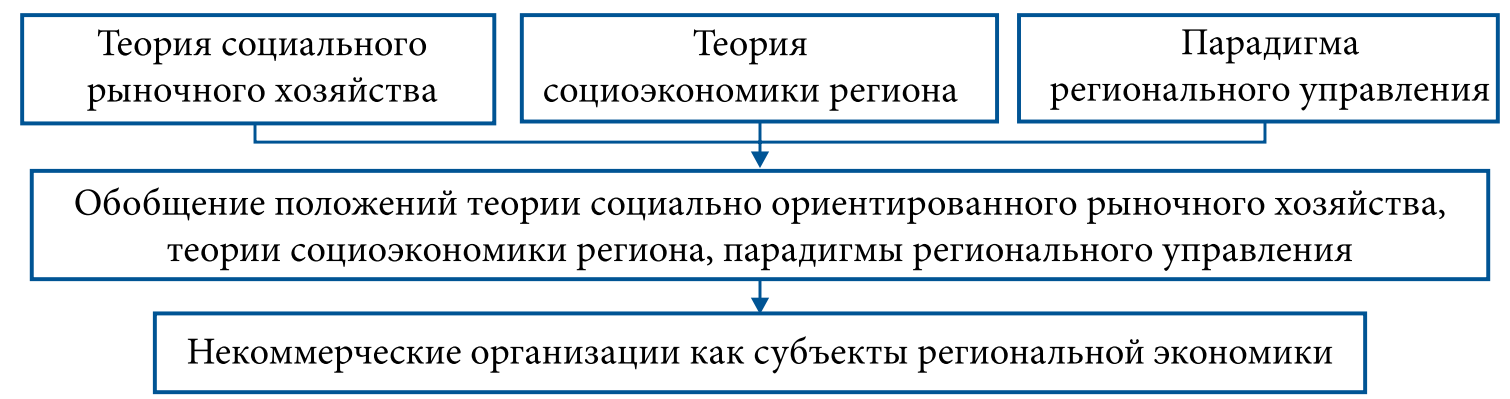

Рис. 1. Теоретическая платформа исследования некоммерческих организаций в региональной экономике

Fig. 1. Theoretical platform for the research of nonprofit organisations in regional economies

формам социально ориентированного рыночного хозяйства». Е. Л. Андреева, В. В. Захарова, А. В. Ратнер [2014, с. 66] справедливо отмечают, что социальное государство является закономерной ступенью развития государственности, на которой происходит изменение роли человека на производстве и смена ведущих отношений «государство личность» на «государство - общество».

Представим характеристику основных положений теории социально ориентированного рыночного хозяйства. Данная теория сформировалась «...на основе работ ордолиберальной Фрайбургской школы, которая возникла еще до Второй мировой войны вокруг Вальтера Ойкена и его коллег. Ее политическая реализация связана с именами Альфреда Мюллер-Армака, который впервые ввел этот термин в политический обиход, и Людвига Эрхарда, внесшего решающий вклад в формирование либерально-конкурентного экономического порядка» [Социальное рыночное хозяйство..., 2017, с. 7]. К разряду классиков социального рыночного хозяйства относятся В. Ойкен, Ф. Бем, Ф. Лутц, Л. Микш, Ф. А. фон Хайек, А. Рюстов, В. Рёпке, Й. Хеффнер, А. Мюллер-Армак, Л. В. Эрхард.

В российской экономической науке проблематика социального рыночного хозяйства относится к числу активно обсуждаемых и представлена трудами таких исследователей, как В. С. Автономов [1999, 2000], С. А. Бартенев [1996], И. Н. Буздалов [2007a, b, 2010], В. П. Гутник $[1995,1997,2002]$, Б. Е. Зарицкий $[1997,2001,2003]$, В. Н. Костюк [1997], Ю. В. Латов [2006a, b, с], С. И. Невский [2015, 2017], Р. М. Нуреев [2006], А. Г. Худокормов [1998, 2005, 2017], А. Ю. Чепуренко [2001].

Социальное направление либерализма. Термин «социальное рыночное хозяйство» был предложен А. Мюллером-Армаком в конце 1940-х годов в его книге «Хозяйственное управление и рыночное хозяйство». Он стремился «... поставить рыночное хозяйство на службу социальному», дав следующее определение: «Социально рыночная экономика - это сознательно сформированный порядок; первейшим принципом его координации должна быть конкуренция» [Müller-Armack, 1946, s. 88]. Ученый отмечал, что «...социальное рыночное хозяйство не есть исключительно теория конкуренции, это скорее идеологическая концепция в том смысле, что целью социального рыночного хозяйства является координация между сферами жизни, представленными рынком, государством и социальными группами. Это диалектическая концепция, в которой социальные цели играют такую же важную роль, как и экономические цели, так что она сочетает экономическую и социальную политику» [Müller-Armack, 1946, s. 10].

По мнению А. Мюллера-Армака, социальное рыночное хозяйство предстает как попытка найти такие формы взаимодействия основных экономических и общественных субъектов, при которых стиль социального гуманизма не нарушал бы рыночных 
механизмов, а меры экономической политики и вообще государственного вмешательства не противоречили бы друг другу [Гутник, 2002].

Ордолиберализм «Фрайбургской школь». Идейными создателями данного направления принято считать В. Ойкена и Ф. Бема. Основной идеей неолибералов стало «...создание вполне определенных условий для эффективного экономического развития в долгосрочной перспективе» [Klump, 1986, s. 405]. Необходимо, чтобы хозяйственная система «...опиралась на фундаментальные принципы демократического и правового государства. Основываясь на конституционных гарантиях основных прав, таких как права свободного передвижения и повсеместного проживания, свободы собственности, слова и вообще свободы личности» [Ойкен, 1995, с. 104]. Теоретические заключения в рамках данного направления строились на таком основополагающем принципе, как неразрывная связь порядка и свободы, т. е. взаимообусловленность и взаимовлияние политического, экономического, социального и правового порядков [Ачалова, 2007].

Социально-гуманистическое направление в неолиберализме. Заметный вклад в формирование теоретических основ концепции социального рыночного хозяйства, внесли В. Рёпке и А. Рюстов. Они считали нецелесообразным чрезмерно активное участие государства (тоталитарные тенденции) в хозяйственной сфере, предлагая придерживаться «третьего пути» социально-экономического развития (см. [Гутник, 2002, с. 51]). Так же, как и ордолибералы, они полагали важным сохранение «сильного государства» для создания и поддержания конкурентного порядка и одновременно выступали за жесткую «индивидуальную ответственность» [Рёпке, 2002, с. 120-121] и против монополизации крупных предприятий как таковых.

Основываясь на глубоком изучении положений теории социального рыночного хозяйства, обоснованных немецкими учеными, Р. М. Нуреев делает вывод о том, что «...основными элементами концепции социального рыночного хозяйства являются: личная свобода; экономическая дееспособность; социальная справедливость» [Нуреев, 2007, с. 9].

Резюмируем вышесказанное: для успешного формирования социального рыночного хозяйства и его дальнейшего развития необходимо наличие «сильного государства», которое выступало бы гарантом «конкурентного порядка», обеспечивая индивидуальную свободу, экономическую дееспособность и социальную справедливость. Государство должно создать необходимые институциональные условия и сформировать правовые рамки для эффективного функционирования рыночного механизма, строго контролируя их соблюдение всеми субъектами хозяйственной деятельности, на федеральном, региональном и муниципальном уровнях. При этом следует избегать вмешательства в экономические процессы, если они не ведут к негативным социальным результатам. Социальная ориентация государства должна быть направлена на создание таких условий, при которых каждый трудоспособный гражданин будет в состоянии обеспечить себе и своей семье желаемый уровень материального благосостояния. Должны быть предоставлены социальные гарантии незащищенным слоям населения, сглаживающие негативные последствия действия рыночных механизмов. А. Н. Дубянский приходит к заключению о том, что «...относительно принципов построения социального порядка немецкие неолибералы однозначно считали, что главным принципом должен быть принцип субсидиарности, т. е. дополнительности. Этот принцип предполагает, что государственные меры в социальной сфере оправданы только тогда, когда частная благотворительность оказывается недостаточной» [Дубянский, 2016, с. 20]. Принцип субсидиарности, по мнению исследователя, может применяться и при проведении региональной политики, нацеленной на выравнивание уровней 
экономического развития различных территорий. Данный вывод весьма важен с позиций нашего исследования, проводимого в русле региональной экономики.

Поскольку современный этап общественного развития характеризуется процессами новой индустриализации, формированием постиндустриальных вызовов и усилением фактора глобальной конкурентоспособности, вполне закономерно вести речь о становлении постиндустриального социального государства в трех составляющих направлениях:

- достижение глобальной конкурентоспособности;

- осуществление новой индустриализации и развитие секторов «неоэкономики»;

- развитие человеческого потенциала и повышение жизненного уровня граждан [Андреева, Захарова, Ратнер, 2014, с. 72].

Мы согласны с Е. Л. Андреевой, В. В. Захаровой, А. В. Ратнера, которые под социальной ориентацией государства понимают создание таких условий, которые обеспечивали бы высокую эффективность развития экономики в условиях глобализации и на этой основе обеспечение социальных приоритетов развития. «Социальная политика является основным системообразующим компонентом государственной экономической политики, который опирается на реализацию основных приоритетов и целей развития страны» [Андреева, Захарова, Ратнер, 2014, с. 72]. Поскольку цели и задачи государственной социальной политики декомпозируются на территориальный уровень, социальные приоритеты развития характерны и для органов государственной власти субъектов Российской Федерации, и для органов местного самоуправления [Дворядкина, 2005].

\section{Теория социоэкономики региона}

Теория социоэкономики региона является элементом теоретического фундамента исследования социально ориентированных некоммерческих организаций в регионе. Представим характеристику ее основных положений.

Социоэкономика - научное междисциплинарное направление, изучающее закономерности экономической жизни общества во времени и пространстве через призму неэкономических критериев и ограничений.

Основателем социоэкономики как научного направления является А. Этциони, профессор социологии Университета им. Дж. Вашингтона. Он идентифицировал критерии, благодаря которым стало возможным выделить социоэкономику в системе общественных наук. В отечественной науке наиболее важные концепты этой парадигмы были изучены Ф. М. Бородкиным [2005, 2006], В. В. Радаевым [2005], М. А. Шабановой [2005, 2006a, b, 2012].

В рамках социоэкономики человек выделяется в качестве основного субъекта социоэкономических отношений, которому свойственна множественность факторов экономической мотивации, подчас лишенная формальной рациональности. Являясь участником рыночного обмена, человек постоянно испытывает противоречивые чувства, влияющие на его конечный выбор, балансируя между морально-нравственными ценностями и альтернативами рационального (экономического) выбора. Мотиваторами его выбора выступают не только экономические интересы (выгода), но и нравственные принципы, социальные привычки, стереотипы, присущие той или иной социальной популяции (этносу, организации, группе) и часто противоречащие рациональному выбору [Etzioni, 2003, p. 115].

М. А. Шабанова [2010, с. 105] дает следующее определение: «Социоэкономика изучает характер и закономерности двусторонних связей между экономическими и социальными аспектами воспроизводства хозяйственных систем разных видов (от фирм 
и домохозяйств до общества в целом) и пытается дать (там, где возможно и необходимо) экономическую оценку этим связям на основе сопоставления широко понимаемых затрат и результатов и учета определенных социальных ограничений». Автор считает, что социоэкономика подходит к решению своих задач применительно к тем или иным хозяйственным системам (подсистемам), сначала выделяя два разных аспекта их функционирования и развития (экономический и социальный), а затем интегрируя их. Связи между социальными и экономическими аспектами жизнедеятельности имеют двусторонний характер. «Экономика, развитая до определенного уровня, “поставляет” ресурсы для функционирования (развития) социума. Объемы и характер (эффективность) распределения доступных экономических ресурсов влияют на развитие образования, здравоохранения, права, уровень и качество жизни разных социальных и профессиональных групп, возможности их мобильности и др. В свою очередь, качество “воспроизведенных" при данных экономических ограничениях людей, культура общества, его социальная структура в следующий момент времени в значительной степени будут определять уровень (пределы) и параметры экономического развития. Аналогичные зависимости между экономическими и социальными аспектами воспроизводства характерны... и для систем более низких уровней - отдельных территорий, секторов, сфер или фирм» [Шабанова, 2010, с. 108], т. е. и для региональных, и локальных социально-экономические систем.

А. А. Шулус [2008, с. 7-8] полагает, что «...социоэкономические отношения есть конкретная историческая форма социально-экономических отношений, то есть воспроизводство рабочей силы, совокупного рабочего на этапе постиндустриального информационного общества». В качестве аргументов автор приводит: изменение роли человека в трудовой деятельности; изменение соотношения между физической и интеллектуальной составляющими; процесс интеграции ипостасей человека как производителя, потребителя и субъекта свободного времени; формирование принципиально иного соотношения функций государства, организаторов производственного процесса, институтов гражданского общества, семьи и личности в процессе воспроизводства человека [Шулус, 2008, с. 8]. Становление постиндустриального общества можно рассматривать и в территориальном аспекте, поэтому данные положения учитываются на региональном и муниципальном уровнях. Пространством для формирования и развития социоэкономических отношений выступают и регионы, и муниципальные образования.

А. В. Сурин также связывает развитие социоэкономики как научного направления с развитием постиндустриального общества. В частности, он отмечает: «Предметом исследования социоэкономики является процесс становления постиндустриального общества, в условиях которого промышленная основа рыночного капитализма вытесняется наукоемкими технологиями, автоматизированными и роботизированными системами, гибкими формами мелкосерийного производства, новыми материалами и биотехнологиями. Эти новации существенно изменяют характеристики современного социума, базовые ориентиры капитализма, формируют контуры “грядущего постиндустриального общества”. Главный критерий капиталистического общества - уровень жизни, который определяется количеством произведенного товара, заменяется критерием качества жизни, измерениями степени развитости человеческого потенциала, доступностью здравоохранения, образования, отдыха, культуры» [Сурин, 2009, с. 4]. Безусловно, формирование инновационного типа производства трансформирует требования к компетенциям работников. Существенно меняется значение такого фактора производства, как способности человека. На региональном и локальном уровнях должны быть созданы условия 
для формирования и развития способностей человека, что является одной из задач функционирования некоммерческих организаций в регионе.

В исследованиях В. А. Сухих развиты теоретико-методологические основания формирования социоэкономики в пространстве региона, что представляет интерес в рамках поставленной нами научной задачи. По его мнению, «...социоэкономика... призвана решать задачи, непосредственно связанные с хозяйствованием, развитием рынка, рыночной конкуренции не только с точки зрения полезности, выигрыша или прибыли, но и с позиций нравственных, правовых, моральных норм и правил, ментальных особенностей, критериев социальной и территориальной справедливости. В этом плане особый смысл приобретает углубленный сопряженный анализ экономических и социальных тенденций и процессов в пространстве тех или иных регионов страны. Социоэкономический способ хозяйствования наиболее ярко может проявиться именно на региональном уровне пространственной организации общества» [Сухих, 2008, с. 3]. Исследователь оперирует понятием региональной социоэкономической системы, которая является пространственно-локализованной и сложно-структурированной, формируется в пространстве субъекта Российской Федерации. Данная система обеспечивает расширенное воспроизводство валового регионального продукта, социально-территориальной общности населения и удовлетворение потребностей и нужд на мезоуровне.

В качестве ключевых сфер социоэкономики региона В. А. Сухих [2008, с. 39] выделяет рост экономики, развитие человеческого потенциала и развитие инфраструктуры. Именно на их регулирование должна быть направлена функционально-целевая модель регионального управления. Региональное управление в контексте социоэкономики с учетом современных трендов развития характеризуется следующими чертами:

- во-первых, разработка и реализация мер управленческого воздействия на региональную экономику в целях обеспечения определенных темпов экономического роста в условиях процессов новой индустриализации, формирования новой экономической повестки;

- во-вторых, разработка и реализация стратегических направлений развития человеческого потенциала региона в целях повышения благосостояния жителей и нейтрализации социальных рисков;

- в-третьих, разработка и реализация механизмов активизации развития институтов гражданского общества как компонента социальной инфраструктуры региона.

Е. Г. Анимица, Т. А. Балина и М. Д. Шарыгин [2016, с. 209] приходят к заключению о том, что «... современный этап развития человеческого общества характеризуется трансформацией региональной экономики в социоэкономику и имеет яркие территориальные различия, отличается неравномерностью, динамичностью и сложностью протекания всех социально-экономических процессов и общественного развития в целом. Трансформация социоэкономики происходит путем ее реструктуризации и усиления социальной ориентации производства, нацеленной на повышение уровня и качества жизни людей». Исследователи показывают, что социоэкономика реализуется на различных территориальных уровнях, проецируется на поселенческий уровень. «Формируясь под воздействием двух взаимообогащающих процессов - экономизация географии и регионализация экономики - социоэкономика отличается антропоцентризмом, что приводит к обновлению региональной парадигмы и всей системы взглядов на процессы размещения производительных сил... Региональная социоэкономика выполняет функции «платформы» развития территориальных общественных систем и возрождения нравственно-этических устоев современного социума (территориальных общностей людей)» [Анимица, Балина, Шарыгин, 2017, с. 13-14]. В качестве доминантного фактора 
региональной социоэкономики отмечается трудоресурсный потенциал, концентрирующий возможности обеспечения производства трудовыми ресурсами. Поскольку человеческий фактор, человеческий потенциал является ключевым элементом социоэкономики, его формирование и развитие неразрывно связано с деятельностью организаций и учреждений социальной сферы, а следовательно, с необходимостью инвестиций в такие виды экономической деятельности, как образование, здравоохранение, культура и искусство, социальное обслуживание и т. п., которые в субъектном контексте представлены, как правило, некоммерческими организациями.

\section{Парадигма регионального управления}

Третьим составным компонентом теоретического фундамента настоящего исследования выступает парадигма регионального управления. Академик А. Г. Гранберг [2000] подчеркивал, что особенности России требуют более активного, по сравнению с типичной мировой практикой, государственного управления в решении проблем пространственного развития страны и устранения неоправданных диспропорций в уровне социально-экономического развития регионов. По мере стабилизации политической ситуации и экономического роста, усиления стратегических приоритетов будет осознаваться потребность в усилении роли регионального управления в решении задач экономического и социального развития. Следует также отметить, что базовые ценности отечественной государственной системы, ее универсальные цели - это сохранение и развитие (приумножение, улучшение):

- территории - путем защиты территориальной целостности страны, ее суверенитета, защиты экономической и национальной безопасности страны, обеспечения ее сбалансированной заселенности;

- населения - путем достижения достойного уровня и качества жизни граждан на всей территории страны, преодоления тенденции депопуляции [Глигич-Золотарева, 2011].

Парадигма регионального управления находится в процессе становления. Согласимся с мнением А. С. Маршаловой, А. С. Новоселова [2012, с. 42] о том, что «...по некоторым теоретическим и методологическим вопросам у экономистов еще не сформировалось единого мнения, не сложилось и терминологическое единство».

По мнению А. К. Осипова [2007, с. 13], «...система регионального управления представляет собой взаимосвязанную совокупность многих систем управления, обеспечивающих реализацию поставленных целей и задач и образующих организационную структуру регионального управления».

И. С. Межов и Е. В. Клецкова [2017] указывают на то, что основным императивом в управлении регионом является обеспечение поступательного, эволюционного развития региона. Для этого императива необходимо, во-первых, сформировать концептуальную модель экономики региона, адекватно представляющую процесс ее функционирования и служащую основой для формирования реальной подсистемы управления регионом; во-вторых, учитывать базовые свойства региональной экономики как сложной, многоуровневой системы, используя скользящее планирование для активного воздействия на ключевые отрасли, внутреннее потребление и межотраслевые обмены.

Е. А. Вечкинзова [2009, с. 388] дает следующее определение: «Региональное управление - есть совокупность воздействий на различные сферы отношений в общественной жизни региона». Так как основной сферой воздействия являются экономические отношения, исследователь приходит к выводу о том, что управление региональным развитием сосредоточивается на управлении развитием экономических отношений, и акцентирует внимание на инновациях. Органы регионального управления (как субъект 
управления) на основании определенных процедур строят целевой образ экономической деятельности региона и своим воздействием инициируют процессы изменений в деятельности субъектов экономики. Эти изменения должны приводить к качественно другому состоянию деятельности субъектов экономики, т. е. новому (измененному) способу организации и/или ведения экономической деятельности - инновациям.

А. А. Степанов и О. В. Ибраева [2014, с. 67] рассматривают региональное управление в ракурсе эффективности социально-экономического развития региона как процесс, направленный на достижение целей развития региона и выражающийся в конкретных действиях, мероприятиях, измеряемых результатах. Теоретический анализ основных элементов понятия «управление результативностью (эффективностью) социально-экономического развития региона», основанный на применении родового генетического подхода, позволил исследователям сформулировать свою точку зрения на сущность данного термина: управление эффективностью развития региональной экономики - это процесс, направленный на достижение позитивных тенденций и результатов социально-экономического развития регионов страны, обеспечение и поддержание режимов их устойчивого и динамичного развития. Авторы подчеркивают, что происходит активизация процессов гуманизации, развития человеческого и социального капитала, в связи с чем основными целями социально-экономического развития регионов становится достижение показателей, характеризующих процессы увеличения доходов, улучшения системы культуры, здравоохранения, образования, питания, отдыха, ликвидации нищеты, воспроизводства окружающей природной среды, а также обеспечения возможностей расширения свободы и самореализации личности. Для этого необходимо эффективное функционирование некоммерческих организаций соответствующих видов экономической деятельности.

Региональное управление как специфический вид менеджмента, который охватывает экономическую, социальную, организационно-структурную, финансовую, инновационную, общественную, политическую сферы жизнедеятельности регионального сообщества, характеризует И. М. Лабазанов. По его мнению, региональное управление, обеспечивающее координацию хозяйственной деятельности, реализацию собственного потенциала, расширенное воспроизводство условий жизнедеятельности населения региона в соответствии с современными общественными потребностями на основе рационального использования ресурсов с учетом региональных факторов и местных особенностей, представляет собой систему форм, методов и инструментов комплексного воздействия на социально-экономические процессы в регионе [Лабазанов, 2010, с. 45]. Автор подчеркивает, что региональное управление должно быть ориентировано на повышение эффективности использования всех видов ресурсов, создание стимулирующих условий и благоприятной среды для результативности хозяйствования и роста качества жизни населения.

Активизация исследования проблем совершенствования регионального управления связана с трансформациями в системе общественно-экономических отношений. Формирование новых элементов в социальной и финансово-экономической среде требует создания соответствующей методологии регионального управления.

А. С. Маршалова и А. С. Новоселов [2012, с. 44] обосновывают положение о том, что управление регионом - это управление его функционированием и развитием. При этом возникает вопрос о содержании управления экономическим и социальным развитием, так как экономические и социальные процессы непосредственно сходятся в результате принятия решений на всех уровнях управления: государственном, региональном и на уровне хозяйственных структур. К компетенции всех уровней власти 
относится в том числе создание благоприятной среды жизнедеятельности людей. По мнению авторов, управление на региональном уровне должно базироваться на системе методологических принципов, отражающих объективные закономерности регионального воспроизводственного процесса:

- целевое управление - интересы региона определяются интересами населения, проживающего на его территории, к числу таких интересов относятся материальное благополучие, возможность духовного развития, физическое здоровье и общий высокий уровень качества жизни;

- использование региональных преимуществ в территориальном разделении труда - с одной стороны, региональная экономика является компонентом единой социально-экономической системы государства, а с другой - относительно самостоятельной воспроизводственной системой, уровень комплексности которой существенно влияет на эффективность ее развития;

- сочетание интересов всех экономических субъектов, участвующих в процессе регионального воспроизводства - механизм регионального управления должен предполагать создание условий для баланса интересов всех структур, участвующих в воспроизводственном процессе на территории;

- экономическая самостоятельность - равноправие различных форм собственности и экономической самостоятельности всех собственников, причем экономическая самостоятельность предполагает четкое распределение полномочий и функций управления между различными уровнями власти и создание финансово-экономических условий для их реализации;

- самофинансирование - развитие региона должно осуществляться в направлении, обеспечивающем возможность покрытия расходных обязательств за счет доходов, образующихся на самой территории; наличие такой схемы финансовых потоков, в которой перераспределительные процессы не являются преобладающими);

- зависимость между эффективностью экономического развития региональной экономики и формированием ресурсной базы социального и общеэкономического развития региона - должны быть учтены и задействованы экономические интересы, стимулирующие развитие экономики и рост ее эффективности;

- ответственность за осуществление функций управления [Маршалова, Новоселов, 2012, c. 46].

Реализация данной системы принципов позволит создать механизм регионального управления, позволяющий решать поставленные социальные и экономические задачи в пространстве региона и муниципальных образований и соответствующий новой парадигме регионального управления.

Сущность и необходимость формирования новой парадигмы регионального управления обосновал Е. Г. Анимица. В качестве причин возрастания научного и практического интереса к регионализму Е. Г. Анимица рассматривает:

- демонтаж административно-плановой экономики и переход к экономике нового типа;

- формирование нового геополитического и экономического пространства после распада СССР;

- изменение государственного устройства, в том числе административных и бюджетных отношений центра и регионов;

- новая регионализация России, в ходе которой появляются новые регионы как социально-экономические, политические и этнокультурные образования;

- развитие нового этапа урбанизации («новый урбанизм»), когда городской образ жизни, развитие инфраструктур и пространственной организации городов определяется 
не столько промышленно-техническими требованиями, сколько требованиями создания современной благополучной среды жизнедеятельности населения;

- неспособность многих регионов, развивавшихся в советское время в нерыночной среде, соответствовать требованиям открытого рынка, обеспечить конкурентоспособность собственного хозяйства не только в глобальном, но и в страновом масштабе;

- усиление конкурентоспособности на мировом рынке небольшого числа регионов с сырьевой направленностью хозяйства [Анимица, 2010].

Сущность новой парадигмы регионального управления раскрывают следующие ее особенности:

1. Базирование парадигмы на сущности региональной проблемы как многогранного явления, охватывающего экономические, социальные, экологические, культурные и иные вопросы.

2. Объект управления - территориальные единицы, в частности национально-государственные и территориально-государственные образования (республика, край, область, автономная область, автономный округ, город федерального значения), а также экономические районы и федеральные округа, которые можно представить как относительно целостные самостоятельные социально-экономические образования.

3. Регион рассматривается как квазикорпорация. Создание корпоративного образа региона приводит к выводу о том, что управление региональным развитием можно основывать на методах менеджмента, а науку о региональном управлении можно назвать региональным менеджментом.

4. Системный подход, согласно которому должна измениться не только теория и методология управления (в том числе и регионального), но и политика последовательного, целенаправленного реформирования всей системы управления (федерального, регионального уровней и местного самоуправления), опирающаяся на конституцию РФ и законы. Региональное управление формируется и изучается как сложный системный объект.

5. Развитие территорий, отвечающее современным требованиям, может быть эффективным при условии соблюдения принципов децентрализации и саморазвития. Естественно, такой процесс может происходить в пределах и с соблюдением необходимых и достаточных общегосударственных установок и ограничений (консультационно-законодательных, институциональных, экономических, социальных).

6. Проблема регионального управления должна рассматриваться в рамках взаимодействия региона с местным самоуправлением. Она не сводится к поиску оптимальных форм и методов взаимодействия региональных и муниципальных органов. Важным является определение полномочий, функций самих территориальных органов, основанное на специфике, целях и задачах развития всего региона.

7. Комплексное, масштабное взаимодействе, как органов государственной власти соседних субъектов РФ, так и хозяйствующих на их территориях бизнес-структур.

8. Активизация использования новых технологий и инструментов в региональном управлении, в том числе стратегического планирования, маркетинга и брендинга территорий, управление изменениями, управление проектами и др.).

9. Факторов становления новой организационно-управленческой культуры, в том числе устанавливающиеся в обществе ценности, воззрения, индивидуальные и групповые нормы поведения, установки, типы взаимодействий [Анимица, 2010].

Обобщение (рис. 2) положений теории социального рыночного хозяйства, теории социоэкономики региона и парадигмы регионального управления представляет собой обосновываемый автором теоретический подход к исследованию некоммерческих организаций в региональной экономике. 

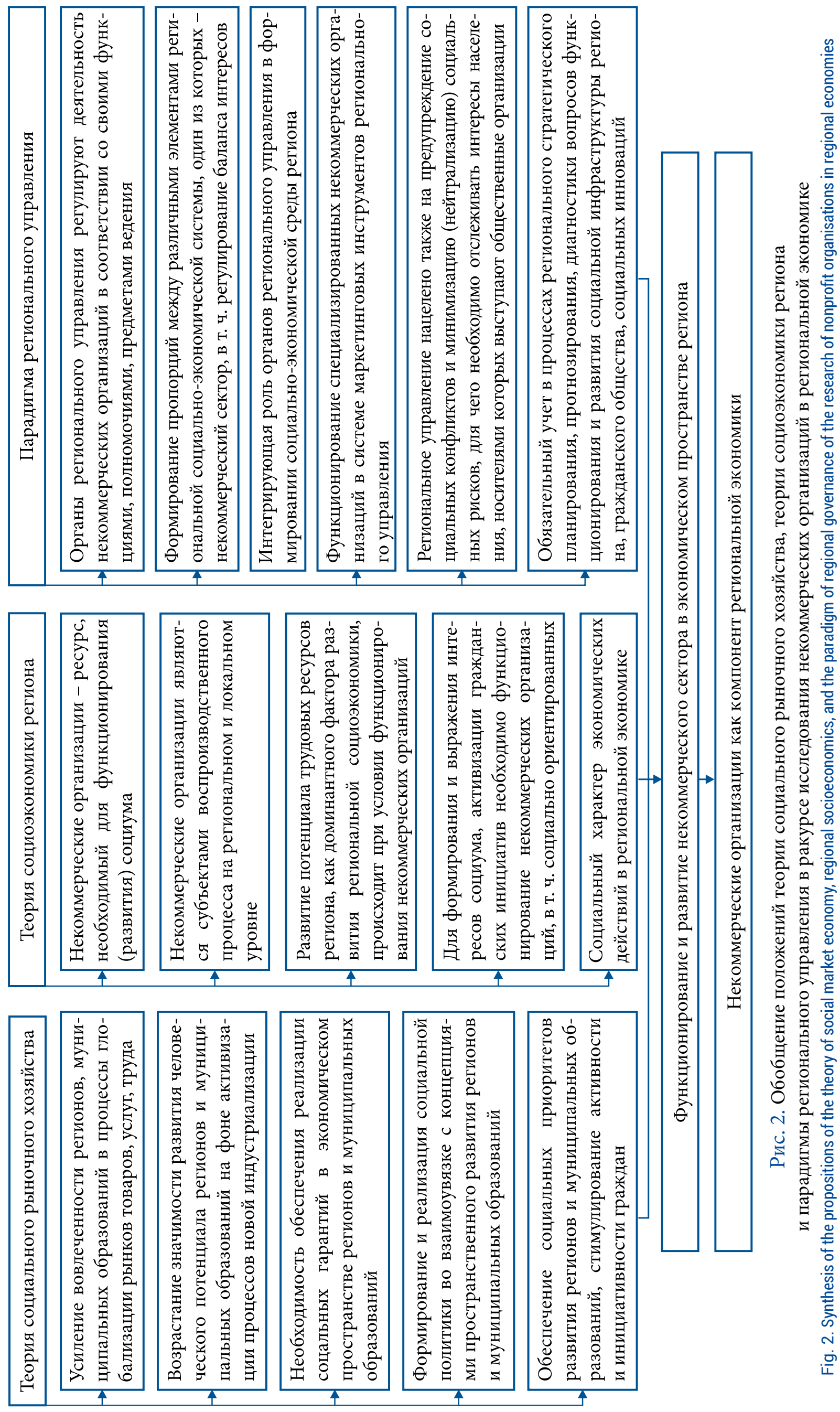


\section{Заключение}

Авторское обобщение положений теории социального рыночного хозяйства в ракурсе региональной экономики и объекта настоящего исследования позволяет представить следующую интерпретацию:

- усиление вовлеченности регионов и муниципальных образований в процессы глобализации рынков услуг, технологий, компетентных специалистов;

- возрастание значимости развития человеческого потенциала регионов и муниципальных образований на фоне активизации процессов новой индустриализации;

- необходимость обеспечения реализации социальных гарантий в экономическом пространстве регионов и муниципальных образований;

- формирование и реализация социальной политики во взаимоувязке с концепциями пространственного развития регионов и муниципальных образований;

- обеспечение социальных приоритетов развития регионов и муниципальных образований, стимулирование активности и инициативности граждан.

Обобщение приведенных выше положений теории социоэкономики региона позволяет сформулировать ряд выводов:

- наличие связей между экономикой и социумом в регионе предполагает интерпретацию некоммерческих организаций как ресурса, необходимого для функционирования (развития) социума (отметим также, что некоммерческие организации, обслуживающие домашние хозяйства - является самостоятельный сектор в СНС);

- взаимосвязи между экономикой и социумом региона нуждаются в экономической оценке с учетом региональных особенностей. Возникает необходимость учета воспроизводственного аспекта их взаимосвязи: некоммерческие организации являются субъектами воспроизводственного процесса на региональном и локальном уровне;

- развитие потенциала трудовых ресурсов региона как доминантного фактора развития региональной социоэкономики, происходит при условии функционирования некоммерческих организаций, находящихся в том числе в ведении органов государственной власти субъекта РФ и органов местного самоуправления;

- в пространстве региона формируются интересы власти, бизнеса и региональных общностей населения; для формирования и выражения интересов социума, активизации гражданских инициатив необходимо функционирование некоммерческих организаций, в том числе социально ориентированных;

- социальный характер экономических действий в региональной экономике. На региональном уровне или уровне муниципального образования данное положение проявляется при оценке возможностей и выборе конкретных мер социально-экономического регулирования, осуществляемого органами государственной власти субъекта РФ или органами местного самоуправления. Необходима координация интересов и ресурсов различных акторов, функционирующих в региональной и муниципальной экономике.

Обобщение подходов к современной парадигме регионального управления позволяет интерпретировать ее ключевые положения в отношении некоммерческих организаций, функционирующих в экономическом пространстве региона, следующим образом:

- органы регионального управления регулируют деятельность некоммерческих организаций в соответствии со своими функциями, полномочиями, предметами ведения;

- в процессе управления региональным социально-экономическим развитием стоит задача не только создать условия для повышения уровня и качества жизни населения, но и сформировать такие пропорции между различными элементами региональной социально-экономической системы, которые обеспечивали бы ее эффективное развитие; одним из таких элементов является некоммерческий сектор региональной экономики; 
- региональное управление строится на принципе сочетания интересов субъектовучастников процесса регионального воспроизводства, следовательно, интересы некоммерческого сектора должны быть сбалансированы с интересами других институциональных секторов в региональной экономике;

- органы регионального управления призваны играть интегрирующую роль в формировании социально-экономической среды региона, в том числе путем создания некоммерческих организаций, включая социально ориентированные как их отдельный вид;

- активизация использования маркетинговых инструментов в процессе регионального управления способствует повышению эффективности управления социально-экономическим развитием региона, в том числе в результате функционирования специализированных некоммерческих организаций;

- региональное управление нацелено на предупреждение социальных конфликтов и минимизацию (нейтрализацию) социальных рисков, для чего необходимо отслеживать интересы населения, носителями которых выступают общественные организации;

- в процессах регионального стратегического планирования, прогнозирования, диагностики функционирования и развития социальной инфраструктуры региона, гражданского общества, социальных инноваций.

\section{Источники}

Андреева Е. Л., Захарова В. В., Ратнер А. В. (2014). Эволюция социального государства: теория и практика вопроса // Журнал экономической теории. № 3. С. 66-73.

Анимица Е. Г. (2010). Региональное управление. Екатеринбург: Изд-во Урал. гос. экон. ун-та. $340 \mathrm{c}$.

Анимица Е. Г., Балина Т. А., Шарыгин М. Д. (2016). Трансформация научных подходов и методов изучения региональной социоэкономики // Вестник ПНИПУ. Социально-экономические науки. № 4. С. 209-218.

Анимица Е. Г., Балина Т. А., Шарыгин М. Д. (2017). Эволюция факторов территориальной организации и трансформации региональной экономики в социоэкономику // Социально-экономическая география. Вестник Ассоциации российских географов-обществоведов. № 6. С. 12-23.

Ачалова Л. В. (2007). Немецкая модель социально-рыночного хозяйства: этапы становления, теоретические основы концепции и необходимость ее модернизации // Вестник Российского экономического университета имени Г. В. Плеханова. № 4. С. 99-105.

Бартенев С. А. (1996). Экономические теории и школы (история и современность). М.: Изд-во БЕК. 352 c.

Бородкин Ф. М. (2005). Взаимодействие социологических и экономических наук. Что впереди? // Социологические исследования. № 12 (260). С. 128-137.

Бородкин Ф. М. (2006а). Социоэкономика. Ст. 1. Путь к господству над хозяйством // Общественные науки и современность. № 4. С. 122-136.

Бородкин Ф. М. (2006b). Социоэкономика. Ст. 2. После конца экономики // Общественные науки и современность. № 5. С. 141-155.

Буздалов И. Н. (2007а). Социальное рыночное хозяйство: пределы свободы и ограничения коммерческой и некоммерческой деятельности // Аграрная Россия. № 3. С. 2-8.

Буздалов И. Н. (2007b). Социальное рыночное хозяйство: принципы, общественные условия становления и эффективного функционирования // Вестник Института экономики РАН. № 1. С. 101-117.

Буздалов И. Н. (2010). Социальное рыночное хозяйство: проблемы становления в агропродовольственном секторе России // Вестник РГНФ. № 4 (61). С. 37-45.

Васина Л. Л., Гутник В. П., Зарицкий Б. Е., Чепуренко А. Ю. (2001). Социальное рыночное хозяйство в Германии: истоки, концепция, практика. М.: Изд-во «Российская политическая энциклопедия». $208 \mathrm{c}$.

Вечкинзова Е. А. (2009). Методологические подходы к управлению региональным развитием // Вестник Чувашского университета. № 4. С. 387-389. 
Глигич-Золотарева М. В. (2011). Стратегия управления региональным развитием: мировые тенденции и отечественный опыт // Наука и образование: хозяйство и экономика; предпринимательство; право и управление. № 11 (17). С. 61-72.

Гольдшмидт Н., Невский С. И., Супян Н. В. (2017). Теория и практика политики порядка в социальном рыночном хозяйстве ФРГ // TERRA ECONOMICUS. T. 15, № 2. C. 57-75.

Гранберг А. Г. (2000). Основы региональной экономики: Учебник. М.: ГУ ВШЭ. 495 с.

Гутник В. П. (2002). Политика хозяйственного порядка в Германии. М.: Экономика. 271 с.

Гутник В. П. (1997). Социальное рыночное хозяйство: опыт Германии // Общество и экономика. № 2. С. 58-91.

Дворядкина Е. Б. (2005). Экономическое развитие городов традиционно-промышленного региона: теория, методология, практика: дис... д-ра экон. наук. Екатеринбург. 373 с.

Дубянский А. Н. (2016). Проблема обязательного государственного страхования в рамках концепции социального рыночного хозяйства // Oikonomos: Journal of Social Market Economy. № 2 (5). C. $19-24$.

Зарицкий Б. Е. (1997). Людвиг Эрхард: секреты «экономического чуда». М.: Издательство БЕК. 298 с.

Зарицкий Б. Е. (2003). Экономика Германии: путь по лестнице, ведущей вниз. М.: Юристь. 304 с.

История экономических учений: учебник. (2000) / под ред. В. Автономова, О. Ананьина, Н. Макашевой. М.: ИНФРА-М. 781 с.

История экономических учений (современный этап). (1998): учебник / под ред. А. Г. Худокормова. М.: ИНФРА-М. 733 с.

Костюк В. Н. (1997). История экономических учений: курс лекций. М.: Центр. 223 с.

Лабазанов И. М. (2010). Современные закономерности, принципы и задачи управления регионом на современном этапе // Региональные проблемы преобразования экономики. № 4 (26). С. 44-49.

Латов Ю. В. (2006а). В поисках содержания социального рыночного хозяйства // Историкоэкономические исследования. Т. 7, № 1. С. 5-7.

Латов Ю. В. (2006b). «Белые пятна» дискурса о социальном рыночном хозяйстве // Историкоэкономические исследования. Т. 7, № 2. С. 37-49.

Латов Ю. В. (2006с). В поисках социального рыночного хозяйства (предисловие к ордо-манифесту) // Экономический вестник Ростовского государственного университета. Т. 4, № 4. С. 107-108.

Маршалова А. С., Новоселов А. С. (2012). Методологические проблемы формирования новой системы регионального управления // Регион: экономика и социология. № 1 (73). С. 40-58.

Межов И. С., Клецкова Е. В. (2017). Системные императивы выбора парадигмы управления региональной экономикой // Вестник факультета управления СПбГЭУ. № 1. С. 183-189.

Механизм регулирования экономики в Германии: как он функционирует и чему учит. (1995) / под общ. ред. В. П. Гутника. М.: ВлаДар.

Морозова Н. И. (2011). Эволюция общества в сторону накопления элементов социализации - ведущая тенденция современного общественно-экономического развития // Бизнес. Образование. Право. Вестник Волгоградского института бизнеса. № 1. С. 64-69.

Невский С. И. (2015). Экономическая политика союзников в послевоенной Западной Германии (1945-1947 годы) // Экономическая политика. Т. 10, № 6. С. 40-78.

Нуреев Р. М. (2007). Социальный рыночный порядок в Германии: путь от теории к практике // Историко-экономические исследования. Т. 7, № 1. С. 8-14.

Нуреев Р. М. (2006). Стратегия и тактика российской модернизации в свете концепции социального рыночного хозяйства // Экономический вестник Ростовского государственного университета. Т. 4, № 4. С. 11-24.

Ойкен В. (1995). Основные принципы экономической политики: пер. с нем. М.: Прогресс. 494 с.

Осипов А. К. (2007). Система регионального управления: понятие, функции и правовое обеспечение // Вестник Удмуртского университета. Сер. Правоведение. № 6. С. 11-18.

Радаев В.В. (2005). Экономическая социология. М.: НИУ «Высшая школа экономики». 603 с.

Рёпке В. Коренные вопросы хозяйственного порядка // Теория хозяйственного порядка: «Фрайбургская школа» и немецкий неолиберализм / пер. с нем. С. Афонцева и др.; под общ. ред. В. П. Гутника. М.: Экономика, 2002. 488 с. 
Социальное рыночное хозяйство - основоположники и классики (2017) / ред.-сост.: К. Кроуфорд, С. И. Невский, Е. В. Романова; предисл. К. Кроуфорд; Фонд Конрада Аденауэра в России. М.: Издательство «Весь Мир». 416 с.

Социальное рыночное хозяйство. Теория и этика экономического порядка в России и Германии (1999). / пер. с нем. под ред. В. С. Автономова. СПб.: Экономическая школа. 368 с.

Социальное рыночное хозяйство в Германии: Истоки, концепция, практика (2001) / под общ. ред. А. Ю. Чепуренко. М.: «РОССПЭН». 208 с.

Социальное рыночное хозяйство: концепции, практический опыт и перспективы применения в России (2007) / под общ. ред. Р. М. Нуреева. М.: Издательский дом ГУ-ВШЭ. 280 с.

Степанов А. А., Ибраева О. В. (2014). Сущность, закономерности и принципы управления эффективностью социально-экономического развития региона // Вестник Московского городского педагогического университета. Сер.: Экономика. № 1 (25). С. 66-72.

Сурин А. В. (2009). Социоэкономика: от теории к парадигме // Вестник Московского университета. Сер. Управление (государство и общество). № 1. С. 3-24.

Сухих В. А. (2008). Развитие теоретико-методологических основ формирования социоэкономики в пространстве региона: автореф. дис... д-ра экон. наук. Екатеринбург. 42 с.

Тарасенко А. (2015). Некоммерческий сектор в странах Европейского союза и России в контексте трансформации государства благосостояния. СПб.: Норма. 224 с.

Теория хозяйственного порядка: «Фрайбургская школа» и немецкий неолиберализм (2002) / пер. с нем., составление, предисловие и общ. ред. В. Гутника. Сер. «Экономическое наследие». М.: Экономика. 482 c.

Ховард М. (2009). Слабость гражданского общества в посткоммунистической Европе / пер. с англ. И. Е. Кокорева. М.: Аспект Пресс. 191 с.

Худокормов А. Г. (2005). Особенности национальных экономических школ в Германии // Мировая экономическая мысль сквозь призму веков: в 5 т. М.: Мысль. С. 29-33.

Худокормов А. Г., Невский С. И. (2017). Национальные экономические школы в Германии и теория социального рыночного хозяйства // Экономическая политика. Т. 12, № 4. С. 204-249.

Шабанова М. А. (2005). Социоэкономика и экономическая социология: точки размежевания и интеграции // Экономическая социология. Т. 6, № 5. С. 12-27.

Шабанова М. А. (2006а). Социоэкономика как наука и новая учебная дисциплина // Мир России: социология, этнология. Т. 15, № 4. С. 94-115.

Шабанова М. А. (2006b). Социоэкономика: от парадигмы к новой науке // Общественные науки и современность. № 1. С. 121-133.

Шабанова М. А. (2010). Социоэкономика и современность (о пользе и рисках экспансии экономического подхода) // Общественные науки и современность. № 4. С. 105.

Шабанова М. А. (2012). Социоэкономика (для экономистов, менеджеров, госслужащих): учеб. пособие. М.: Экономика.

Шулус А. А. (2008). Социоэкономика как межотраслевая наука: предмет, методы, формы институционализации. Труд и социальные отношения. № 1. С. 4-12.

Экономическая теория в историческом развитии: взгляд из Франции и России (2017): монография / под общ. ред. А. Г. Худокормова, А. Лапидюса. М.: ИНФРА-М. 668 с.

Baker G. (2002). Civil society and democratic theory: Alternative voices. L.: Routledge. 191 p.

Becker G. (1993). Human capital: A theoretical and empirical analysis. Chicago: University of Chicago Press. 412 p.

Borgaza C., Tortia E. (2010). The economics of social enterprises. An interpretative framework. In: Becchetti L., Borgaza C. (eds.) The economics of social responsibility: The world of social enterprises. Routledge, pp.15-33.

Etzioni A. (1973). The third sector and domestic missions. Public Administration Review, vol. 33, issue 4 , pp. 314-323.

Etzioni A. (2003). Toward a new socio-economic paradigm. Socio-Economic Review, vol. 1, no. 1, pp. 105-108. Fukuyama F. (1995). Trust: The social virtues and the creation of prosperity. N.Y.: Free Press. 458 p.

Hansmann H. (1987). Economic theories of nonprofit organizations. In: Powell W. W. (ed.) The nonprofit sector: A research handbook. New Haven, CT: Yale University Press. 459 p. 
Keane J. (2003). Global civil society? N. Y.: Cambridge University Press. 220 p.

Klump R. (1986). Die Wirtschaftsordnung der Bundesrepublik Deutschland - Historische Wurzeln. In: Vaubel R., Barbier H. D. (eds.). Marktwirtschaft - Ein Handbuch. Pfullingen. 405 p.

Levitt T. (1973). The third sector. New tactics for a responsive society. N. Y.: Amacom Press.182 p.

Madison G. B. (1998). The political economy of civil society and human rights. L.: Routledge. 301 p.

Muller-Armack A. (1946). Wirtschaftslenkung und Marktwirtschaft. Hamburg. 88 p.

Nielsen W. (1979). The endangered sector. N. Y.: Columbia University Press. 279 p.

North D. (1990). Institutions, institutional change and economic performance. N. Y.: Cambridge University Press.

Olson M. (1982). The rise and decline of nations: Economic growth, stagflation, and social rigidities. New Haven, CT: Yale University Press. 273 p.

Putnam R. D. (January, 1995). Bowling alone: America's declining social capital. Journal of Democracy, vol. 6, issue 1, pp. 65-78.

Schmitter Ph. C. (1999). The future of democracy: Could it be a matter of scale. Social Research, vol. 66, issue 3, pp. 933-958.

Seligman A. B. (1997). The problem of trust. Princeton, NJ: Princeton University Press. 231 p.

Walzer M. (1998). Toward a global civil society. Providence, RI: Berghahn Books. 341 p.

Weisbrod B. (1997). The future of nonprofit sector: Its entwining with private enterprise and government. Journal of Policy Analysis and Management, vol. 16, issue 4, pp. 541-555. DOI: https://doi. org/10.1002/(SICI)1520-6688(199723)16:4<541::AID-PAM2>3.0.CO;2-G

\section{Информация об авторах}

Дворядкина Елена Борисовна, доктор экономических наук, профессор, профессор кафедры региональной, муниципальной экономики и управления Уральского государственного экономического университета, 620144, РФ, г. Екатеринбург, ул. 8 Марта/Народной Воли, 62/45 Контактный телефон: +7 (343) 221-27-48, e-mail: dvoryadkina@usue.ru

Простова Дина Михайловна, старший преподаватель кафедры иностранных языков Уральского государственного экономического университета, 620144, РФ, г. Екатеринбург, ул. 8 Марта/Народной Воли, 62/45

Контактный телефон: +7 (343) 221-27-54, e-mail: citygirl81@yandex.ru

Elena B. Dvoryadkina Ural State University of Economics, Ekaterinburg, Russia

Dina M. Prostova Ural State University of Economics, Ekaterinburg, Russia

\section{Nonprofit organisations in the regional economy: A theoretical approach to the research}

Abstract. Achieving the necessary rates of regions and municipalities' economic growth is impossible without the development of the third sector of economy constituted by nonprofit organisations. The paper justifies the relevance of creating a new theoretical approach for studying the functioning and development of nonprofit organisations in the regional economy. The methodological basis of the research is a combination of the theories of social market economy and regional socioeconomics, and a paradigm of regional governance. Current studies of nonprofit organisations mainly focus on the applied aspects of their functioning, and issues of their interaction with public authorities and local government, producing a wealth of scientific 
outcomes not only in the field of economics, but also in legal, political and social sciences. However, the theoretical and methodological developments for forming a conceptual framework to investigate nonprofit organisations in economic space of a region are obviously in deficit. The authors formulate a number of propositions to validate the importance of studying nonprofit organisations in economic space of the region applying the three theories. First, generalisation of the theory of social market economy enabled the authors to put arguments in favour of the importance of enhancing human potential in regions and municipalities against the background of the new industrialisation. Second, within the theory of regional socieconomics, the researchers prove the connections between the economy and society in a region; therefore, nonprofit organisations can be interpreted as a resource necessary for functioning and development of the society, as well as for identification and expression of its interests. Finally, interpretation of the paradigm of regional governance allowed drawing a conclusion that regional socioeconomic development encounters a twofold task: to create conditions for improving the standards of living and to balance proportions between the elements of the regional socioeconomic system (one of which is the nonprofit sector) in a way, which would ensure its efficiency. The research findings provide a theoretical basis for further exploration of the functioning and development of nonprofit organisations in regional economic space.

Keywords: nonprofit organisation; region; regional economy; theory of social market economy; regional socioeconomics; paradigm of regional governance.

For citation: Dvoryadkina E. B., Prostova D. M. Nekommercheskie organizatsii v regional'noy ekonomike: teoreticheskiy podkhod $\mathrm{k}$ issledovaniyu [Nonprofit organisations in the regional economy: A theoretical approach to the research]. Journal of New Economy, 2019, vol. 20, no. 4, pp. 47-69. DOI: 10.29141/2073-1019-2019-20-4-3

Received June 24, 2019.

\section{References}

Andreeva E. L., Zakharova V. V., Ratner A. V. (2014). Evolyutsiya sotsial'nogo gosudarstva: teoriya i praktika voprosa [The evolution of the social state: Theory and practice matter]. Zhurnal ekonomicheskoy teorii $=$ Russian Journal of Economic Theory, no. 3, pp. 66-73. (in Russ.)

Animitsa E. G. (2010). Regional'noe upravlenie. [Regional governance]. Ekaterinburg: Ural State University of Economics. 340 p. (in Russ.)

Animitsa E. G., Balina T. A., Sharygin M. D. (2016). Transformatsiya nauchnykh podkhodov i metodov izucheniya regional'noy sotsioekonomiki [Transformation of scientific approaches and methods of studying regional socioeconomics]. Vestnik PNIPU. Sotsial'no-ekonomicheskie nauki = PNRPU Sociology and Economics Bulletin, no. 4, pp. 209-218. (in Russ.)

Animitsa E. G., Balina T. A., Sharygin M. D. (2017). Evolyutsiya faktorov territorial'noy organizatsii i transformatsii regional'noy ekonomiki v sotsioekonomiku [Evolution factors of territorial organisation and the transformation of the regional economy in socioeconomics]. Sotsialno-ekonomicheskaya geografiya. Vestnik Assotsiatsii rossiyskikh geografov-obshchestvovedov = Socioeconomic Geography. Bulletin of the Association of Russian Social Geographers, no. 6, pp. 12-23. (in Russ.)

Achalova L. V. (2007). Nemetskaya model' sotsial'no-rynochnogo khozyaystva: etapy stanovleniya, teoreticheskie osnovy kontseptsii i neobkhodimost' ee modernizatsii [The German model of social market economy: Stages of formation, theoretical foundations of the concept and the need for modernisation]. Vestnik Rossiyskogo ekonomicheskogo universiteta imeni G. V. Plekhanova = Bulletin of the Plekhanov Russian University of Economics, no. 4, pp. 99-105. (in Russ.)

Bartenev S. A. (1996). Ekonomicheskie teorii i shkoly (istoriya i sovremennost') [Economic theories and schools (history and modernity)]. Moscow: BEK Publ. 352 p. (in Russ.) 
Borodkin F. M. (2005). Vzaimodeystvie sotsiologicheskikh i ekonomicheskikh nauk. Chto vperedi? [The interaction of sociological and economic sciences. What is ahead?]. Sotsiologicheskie issledovaniya $=$ Sociological Studies, no. 12 (260), pp. 128-137. (in Russ.)

Borodkin F. M. (2006a). Sotsioekonomika. St. 1. Put' k gospodstvu nad khozyaystvom [Socioeconomics. Paper 1 . The path to domination over the economy]. Obshchestvennye nauki i sovremennost = Social Sciences and Modernity, no. 4, pp. 122-136. (in Russ.)

Borodkin F. M. (2006b). Sotsioekonomika. St. 2. Posle kontsa ekonomiki [Socioeconomics. Paper 2. After the end of the economy]. Obshchestvennye nauki i sovremennost = Social Sciences and Modernity, no. 5, pp. 141-155. (in Russ.)

Buzdalov I. N. (2007a). Sotsial'noe rynochnoe khozyaystvo: predely svobody i ogranicheniya kommercheskoy i nekommercheskoy deyatel'nosti [Social market economy: The limits of freedom and restrictions on commercial and non-commercial activities]. Agrarnaya Rossiya = Agricultural Russia, no. 3, pp. 2-8. (in Russ.)

Buzdalov I. N. (2007b). Sotsial'noe rynochnoe khozyaystvo: printsipy, obshchestvennye usloviya stanovleniya i effektivnogo funktsionirovaniya [Social market economy: Principles, social conditions of the establishment and effective functioning]. Vestnik Instituta ekonomiki Rossiyskoy akademii nauk = Vestnik of the Institute of Economics of the Russian Academy of Sciences, no. 1, pp. 101-117. (in Russ.)

Buzdalov I. N. (2010). Sotsial'noe rynochnoe khozyaystvo: problemy stanovleniya v agroprodovol'stvennom sektore Rossii. [Social market economy: problems of formation in the agro-food sector in Russia]. Vestnik Rossiyskogo gumanitarnogo nauchnogo fonda = Bulletin of the Russian Scientific Foundation for Humanities, no. 4 (61), pp. 37-45. (in Russ.)

Vasina L. L., Gutnik V. P., Zaritskiy B. E., Chepurenko A. Yu. (2001). Sotsial'noe rynochnoe khozyaystvo $v$ Germanii: istoki, kontseptsiya, praktika [The social market economy in Germany: Origins, concept, practice]. Moscow: "Rossiyskaya politicheskaya entsiklopediya" Publ. 208 p. (in Russ.)

Vechkinzova E. A. (2009). Metodologicheskie podkhody k upravleniyu regional'nym razvitiem [Methodological approaches to regional development management]. Vestnik Chuvashskogo universiteta = Bulletin of the Chuvash University, no. 4, pp. 387-389. (in Russ.)

Gligich-Zolotareva M. V. (2011). Strategiya upravleniya regional'nym razvitiem: mirovye tendentsii i otechestvennyy opyt [Regional development management strategy: Worldwide trends and domestic experience]. Nauka i obrazovanie: khozyaystvo i ekonomika; predprinimatel'stvo; pravo i upravlenie $=$ Science and Education: Economy and Economics; Entrepreneurship; Law and Administration, no. 11 (17), pp. 61-72. (in Russ.)

Goldshmidt N., Nevskiy S. I., Supyan N. V. (2017). Teoriya i praktika politiki poryadka v sotsialnom rynochnom khozyaystve FRG [Theory and practice of the order policies in the social market economy of Germany]. TERRA ECONOMICUS, vol. 15, no 2, pp. 57-75. (in Russ.)

Granberg A. G. (2000). Osnovy regional'noy ekonomiki [Basics of the regional economy]. Moscow: Higher School of Economics. 495 p. (in Russ.)

Gutnik V. P. (2002). Politika khozyaystvennogo poryadka v Germanii [Economic order policy in Germany]. Moscow: Ekonomika Publ. 271 p. (in Russ.)

Gutnik V. P. (1997). Sotsial'noe rynochnoe khozyaystvo: opyt Germanii [Social market economy: German experience]. Obshchestvo i ekonomika = Society and Economics, no. 2, pp. 58-91.

Dvoryadkina E. B. (2005). Ekonomicheskoe razvitie gorodov traditsionno-promyshlennogo regiona: teoriya, metodologiya, praktika. Diss. dokt. ekon. nauk [Urban economic development traditionally industrial region: The theory, methodology, practice. Dr. econ. sci. diss.]. Ekaterinburg. 373 p. (in Russ.)

Dubyanskiy A. N. (2016). Problema obyazatel'nogo gosudarstvennogo strakhovaniya v ramkakh kontseptsii sotsial'nogo rynochnogo khozyaystva [The problem of compulsory state insurance within the concept of social market economy]. Oikonomos: Journal of Social Market Economy, no. 2 (5), pp. 19-24. (in Russ.)

Zaritskiy B. E. (1997). Lyudvig Erkhard: sekrety "ekonomicheskogo chuda" [Ludwig Erhard: The secrets of the "economic miracle"]. Moscow: BEK Publ. 298 p. (in Russ.)

Zaritskiy B. E. (2003). Ekonomika Germanii: put' po lestnitse, vedushchey vniz [Germany's economy: The way up the stairs leading down]. Moscow: Yurist Publ. 304 p. (in Russ.)

Avtonomov V., Ananyina O., Makasheva N. (eds.) (2000). Istoriya ekonomicheskikh ucheniy [The history of economic thought]. Moscow: INFRA-M. 781 p. (in Russ.) 
Khudokormov A. G. (ed.) (1998). Istoriya ekonomicheskikh ucheniy (sovremennyy etap) [The history of economic thought (modern stage)]. Moscow: INFRA-M Publ. 733 p. (in Russ.)

Kostyuk V. N. (1997). Istoriya ekonomicheskikh ucheniy: kurs lektsiy [The history of economic thought: Lecture course]. Moscow: Tsentr Publ. 223 p. (in Russ.)

Labazanov I. M. (2010). Sovremennye zakonomernosti, printsipy i zadachi upravleniya regionom na sovremennom etape [Modern regularities, principles, and tasks of regional governance at the present stage]. Regionalnye problemy preobrazovaniya ekonomiki $=$ Regional problems of transforming the economy, no. 4 (26), pp. 44-49. (in Russ.)

Latov Yu. V. (2006a). V poiskakh soderzhaniya sotsial'nogo rynochnogo khozyaystva [In search of the content of the social market economy]. Istoriko-ekonomicheskie issledovaniya $=$ Historical and Economic Research, vol. 7, no. 1.pp. 5-7. (in Russ.)

Latov Yu. V. (2006b). "Belye pyatna" diskursa o sotsial'nom rynochnom khozyaystve ["White spots" in the discourse of the social market economy]. Istoriko-ekonomicheskie issledovaniya = Historical and Economic Research, vol. 7, no. 2, pp. 37-49. (in Russ.)

Latov Yu. V. (2006c). V poiskakh sotsial'nogo rynochnogo khozyaystva (predislovie k ordo-manifestu) [In search of a social market economy (the preface to the ordo-manifesto)]. Ekonomicheskiy vestnik Rostovskogo gosudarstvennogo universiteta = Economic Bulletin of the Rostov State University, vol. 4, no 4, pp. 107-108. (in Russ.)

Marshalova A. S., Novoselov A. S. (2012). Metodologicheskie problemy formirovaniya novoy sistemy regional'nogo upravleniya [Methodological problems of the formation of a new regional governance system]. Region: ekonomika i sotsiologiya = Region: Economics and Sociology, no. 1 (73), pp. 40-58. (in Russ.)

Mezhov I. S., Kletskova E. V. (2017). Sistemnye imperativy vybora paradigmy upravleniya regional'noy ekonomikoy [Systemic imperatives in the selection of control paradigm for regional economies]. Vestnik fakulteta upravleniya SPbGEU = Bulletin of the Management Faculty of the Saint Petersburg University of Economics, no 1, pp. 183-189. (in Russ.)

Gutnik V. P. (ed.) (1995). Mekhanizm regulirovaniya ekonomiki v Germanii: kak on funktsioniruet $i$ chemu uchit [The mechanism of economic regulation in Germany: How it functions and what it teaches]. Moscow: VlaDar Publ. (in Russ.)

Morozova N. I. (2011). Evolyutsiya obshchestva v storonu nakopleniya elementov sotsializatsii - vedushchaya tendentsiya sovremennogo obshchestvenno-ekonomicheskogo razvitiya [The evolution of society towards the accumulation of elements of socialisation is the leading trend in modern socioeconomic development]. Biznes. Obrazovanie. Pravo. Vestnik Volgogradskogo instituta biznesa = Business. Education. Law. Bulletin of the Volgograd Institute of Business, no. 1, pp. 64-69. (in Russ.)

Nevskiy S. I. (2015). Ekonomicheskaya politika soyuznikov v poslevoennoy Zapadnoy Germanii (1945-1947 gody) [The economic policy of the allies in the post-war West Germany (1945-1947)]. Ekonomicheskaya politika = Economic Policy, vol. 10, no. 6, pp. 40-78. (in Russ.)

Nureev R. M. (2007). Sotsial'nyy rynochnyy poryadok v Germanii: put' ot teorii k praktike [The social market order in Germany: The path from theory to practice]. Istoriko-ekonomicheskie issledovaniya = Historical and Economic Research, vol. 7, no. 1, pp. 8-14. (in Russ.)

Nureev R. M. (2006). Strategiya i taktika rossiyskoy modernizatsii v svete kontseptsii sotsial'nogo rynochnogo khozyaystva [Strategy and tactics of Russian modernisation in the light of the concept of social market economy]. Ekonomicheskiy vestnik Rostovskogo gosudarstvennogo universiteta $=$ Economic Bulletin of the Rostov State University, vol. 4, no. 4, pp. 11-24. (in Russ.)

Oyken V. (1995). Osnovnye printsipy ekonomicheskoy politiki [Basic principles of economic policy]. Moscow: Progress. 494 p. (in Russ.)

Osipov A. K. (2007). Sistema regional'nogo upravleniya: ponyatie, funktsii i pravovoe obespechenie [Regional management: concept, functions and legal support]. Vestnik Udmurtskogo universiteta. Seriya: Pravovedeniye $=$ Bulletin of Udmurt University. Series: Law, no. 6, pp. 11-18. (in Russ.)

Radaev V. V. (2005). Ekonomicheskaya sotsiologiya. [Economic sociology]. Moscow: Higher School of Economics. 603 p. (in Russ.)

Ryopke V. Fundamental questions of the economic order. In: Gutnik V. P. (ed.) Teoriya khozyaystvennogo poryadka: "Frayburgskaya shkola" $i$ nemetskiy neoliberalizm [Theory of the economic order: The Freiburg School and German neoliberalism]. Moscow: Ekonomika Publ., 2002. 488 p. 
Krouford K., Nevskiy S. I., Romanova E. V. (2017). Sotsial'noe rynochnoe khozyaystvo - osnovopolozhniki i klassiki [Social market economy - the founders and classics]. Moscow: "Ves Mir" Publ. 416 p. (in Russ.)

Avtonomov V. S. (ed.) (1999). Sotsial'noe rynochnoe khozyaystvo. Teoriya i etika ekonomicheskogo poryadka $v$ Rossii i Germanii [Social market economy. Theory and ethics of the economic order in Russia and Germany]. Saint Petersburg: Ekonomicheskaya shkola Publ. 368 p. (in Russ.)

Chepurenko A. Yu. (ed.) (2001). Sotsialnoe rynochnoe khozyaystvo v Germanii: Istoki, kontseptsiya, praktika [Social market economy in Germany: Origins, concept, practice]. Moscow: "ROSSPEN" Publ. 208 p. (in Russ.)

Nureev R. M. (ed.) (2007). Sotsial'noe rynochnoe khozyaystvo: kontseptsii, prakticheskiy opyt i perspektivy primeneniya $v$ Rossii [Social market economy: concepts, practical experience and application prospects in Russia]. Moscow: Higher School of Economics. 280 p. (in Russ.)

Stepanov A. A., Ibraeva O. V. (2014). Sushchnost', zakonomernosti i printsipy upravleniya effektivnost'yu sotsial'no-ekonomicheskogo razvitiya regiona [The essence, patterns and principles of managing the effectiveness of socioeconomic development of a region]. Vestnik Moskovskogo gorodskogo pedagogicheskogo universiteta. Seriya: Ekonomika = Bulletin oa the Moscow State Pedagogical University. Series: Economics, no. 1 (25), pp. 66-72. (in Russ.)

Surin A. V. (2009). Sotsioekonomika: ot teorii k paradigm. [Socioeconomics: From theory to a paradigm]. Vestnik Moskovskogo universiteta. Seriya: Upravlenie (gosudarstvo i obshchestvo) = Bulletin of the Moscow University. Series: Management (the state and society), no. 1, pp. 3-24. (in Russ.)

Sukhikh V. A. (2008). Razvitie teoretiko-metodologicheskikh osnov formirovaniya sotsioekonomiki v prostranstve regiona. Avtoref. Diss. dokt. ekon. nauk. [Development of theoretical and methodological bases of socioeconomics in the regional space. Abstract of Dr. econ. sci. diss.]. Ekaterinburg. 42 p. (in Russ.)

Tarasenko A. (2015). Nekommercheskiy sektor v stranakh Evropeyskogo soyuza i Rossii v kontekste transformatsii gosudarstva blagosostoyaniya. [Nonprofit sector in the countries of the European Union and Russia in the context of the transformation of the welfare state]. Saint Petersburg: Norma Publ. 224 p. (in Russ.)

Gutnik V. (ed.) (2002). Teoriya khozyaystvennogo poryadka: "Frayburgskaya shkola" i nemetskiy neoliberalizm [The theory of economic order: "Freiburg School" and the German neo-liberalism]. Moscow: Ekonomika Publ., 482 p. (in Russ.)

Khovard M. (2009). Slabost' grazhdanskogo obshchestva v postkommunisticheskoy Evrope [The weakness of civil society in the post-communist Europe]. Moscow: Aspekt Press Publ. 191 p. (in Russ.)

Khudokormov A. G. (2005). Specifics of the national economic schools in Germany]. In: Mirovaya ekonomicheskaya mysl' skvoz' prizmu vekov [World economic thought through the prism of centuries]. Moscow: Mysl Publ., pp. 29-33. (in Russ.)

Khudokormov A. G., Nevskiy S. I. (2017). Natsional'nye ekonomicheskie shkoly v Germanii i teoriya sotsial'nogo rynochnogo khozyaystva. [National economic schools in Germany and the theory of social market economy]. Ekonomicheskaya politika = Economic Policy, vol. 12, no. 4, pp. 204-249. (in Russ.)

Shabanova M. A. (2005). Sotsioekonomika i ekonomicheskaya sotsiologiya: tochki razmezhevaniya $\mathrm{i}$ integratsii [Socioeconomics and economic sociology: The point of disengagement and integration]. Ekonomicheskaya sotsiologiya = Economic Sociology, vol. 6, no. 5, pp. 12-27. (in Russ.)

Shabanova M. A. (2006a). Sotsioekonomika kak nauka i novaya uchebnaya distsiplina [Socioeconomics as a science and a new discipline]. Mir Rossii: sotsiologiya, etnologiya = Russia's World: Sociology, Ethnology, vol. 15, no. 4, pp. 94-115. (in Russ.)

Shabanova M. A. (2006b). Sotsioekonomika: ot paradigmy k novoy nauke [Socioeconomics: From a paradigm to a new science]. Obshchestvennye nauki $i$ sovremennost $=$ Social Sciences and Modernity, no. 1. pp. 121-133. (in Russ.)

Shabanova M. A. (2010). Sotsioekonomika i sovremennost' (o pol'ze i riskakh ekspansii ekonomicheskogo podkhoda) [Socioeconomics and the present (on the benefits and risks of the economic approach expansion)]. Obshchestvennye nauki i sovremennost $=$ Social Sciences and Modernity, no. 4. p. 105. (in Russ.) 
Shabanova M. A. (2012). Sotsioekonomika [Socioeconomics]. Moscow: Ekonomika Publ. 559 p. (in Russ.)

Shulus A. A. (2008). Sotsioekonomika kak mezhotraslevaya nauka: predmet, metody, formy institutsionalizatsii [Socioeconomics as a cross-sectoral discipline: Subject, methods, institutionalisation forms]. Trud $i$ sotsialnye otnosheniya $=$ Labor and Social Relations Journal, no. 1, pp. 4-12. (in Russ.)

Khudokormov A. G., Lapidyus A. (eds.) (2017). Ekonomicheskaya teoriya $v$ istoricheskom razvitii: vzglyad iz Frantsii i Rossii [Economic theory in historical development: A view from France and Russia]. Moscow: INFRA-M Publ. 668 p. (in Russ.)

Baker G. (2002). Civil society and democratic theory: Alternative voices. L.: Routledge. $191 \mathrm{p}$.

Becker G. (1993). Human capital: A theoretical and empirical analysis. Chicago: University of Chicago Press. 412 p.

Borgaza C., Tortia E. (2010). The economics of social enterprises. An interpretative framework. In: Becchetti L., Borgaza C. (eds.) The economics of social responsibility: The world of social enterprises. Routledge, pp.15-33.

Etzioni A. (1973). The third sector and domestic missions. Public Administration Review, vol. 33, issue 4 , pp. 314-323.

Etzioni A. (2003). Toward a new socio-economic paradigm. Socio-Economic Review, vol. 1, no. 1, pp. 105-108.

Fukuyama F. (1995). Trust: The social virtues and the creation of prosperity. N.Y.: Free Press. 458 p.

Hansmann H. (1987). Economic theories of nonprofit organizations. In: Powell W. W. (ed.) The nonprofit sector: A research handbook. New Haven, CT: Yale University Press. 459 p.

Keane J. (2003). Global civil society? N. Y.: Cambridge University Press. 220 p.

Klump R. (1986). Die Wirtschaftsordnung der Bundesrepublik Deutschland - Historische Wurzeln. In: Vaubel R., Barbier H. D. (eds.). Marktwirtschaft - Ein Handbuch. Pfullingen. 405 p.

Levitt T. (1973). The third sector. New tactics for a responsive society. N. Y.: Amacom Press.182 p.

Madison G. B. (1998). The political economy of civil society and human rights. L.: Routledge. 301 p.

Muller-Armack A. (1946). Wirtschaftslenkung und Marktwirtschaft. Hamburg. 88 p.

Nielsen W. (1979). The endangered sector. N. Y.: Columbia University Press. 279 p.

North D. (1990). Institutions, institutional change and economic performance. N. Y.: Cambridge University Press.

Olson M. (1982). The rise and decline of nations: Economic growth, stagflation, and social rigidities. New Haven, CT: Yale University Press. 273 p.

Putnam R. D. (January, 1995). Bowling alone: America's declining social capital. Journal of Democracy, vol. 6, issue 1, pp. 65-78.

Schmitter Ph. C. (1999). The future of democracy: Could it be a matter of scale. Social Research, vol. 66, issue 3, pp. 933-958.

Seligman A. B. (1997). The problem of trust. Princeton, NJ: Princeton University Press. 231 p.

Walzer M. (1998). Toward a global civil society. Providence, RI: Berghahn Books. 341 p.

Weisbrod B. (1997). The future of nonprofit sector: Its entwining with private enterprise and government. Journal of Policy Analysis and Management, vol. 16, issue 4, pp. 541-555. DOI: https://doi. org/10.1002/(SICI)1520-6688(199723)16:4<541::AID-PAM2>3.0.CO;2-G

\section{Information about the authors}

Elena B. Dvoryadkina, Dr. Sc. (Econ.), Prof. of Regional, Municipal Economics and Governance Dept., Ural State University of Economics, 62/45 8 Marta/Narodnoy Voli St., Ekaterinburg, 620144, Russia Phone: (343) 221-27-48, e-mail: dvoryadkina@usue.ru

Dina M. Prostova, Sr. Lecturer of Foreign Languages Dept., Ural State University of Economics, 62/45 8 Marta/Narodnoy Voli St., Ekaterinburg, 620144, Russia

Phone: (343) 221-27-54, e-mail: citygirl81@yandex.ru

(с) Дворядкина Е. Б., Простова Д. М., 2019 
Д. С. Бенц Челябинский государственный университет, г. Челябинск, Российская Федерация

\section{Моделирование эколого-экономической эффективности Уральского региона}

Аннотация. В последние годы Уральский регион столкнулся не только с существенным замедлением темпов экономического роста, но и с серьезными экологическими проблемами. Методологической базой исследования является неоклассическая экономическая теория, согласно которой экономический рост можно описать при помощи производственной функции, отражающей зависимость реализуемого объема выпуска от применяемых факторов производства. Автор расширил «набор» факторов производства, добавив к классическим независимым переменным - труду и капиталу - показатели объема промышленного производства, среднедушевых доходов населения и затрат на технологические инновации. Корреляционный анализ показал наиболее тесную связь между экономическим ростом и темпами роста среднедушевых доходов населения и инвестиций в основной капитал. Кроме того, выявлена умеренная связь темпов роста выбросов загрязняющих веществ в атмосферу и темпов роста промышленного производства, а также текущих затрат на охрану окружающей среды. Были построены четыре регрессии, две из которых представляют собой множественную нелинейную регрессию, две - парную линейную. Первая регрессия отражает зависимость темпов экономического роста от факторов, упомянутых выше, вторая регрессия показывает зависимость темпов роста вредных выбросов в атмосферу от темпов роста промышленного производства, текущих и капитальных затрат на охрану окружающей среды. В парных линейных регрессиях в качестве независимой переменной выступает темп роста промышленного производства. Зависимыми переменными являются в первом случае темп роста валового регионального продукта, во втором - коэффициент экологической эффективности. Результаты исследования заключаются в определении оптимального темпа роста промышленного производства $(0,95)$, при котором возможно снижение выбросов в атмосферу на $4 \%$.

Ключевые слова: экономический рост региона; экологическая эффективность региона; Уральский регион; концепция эколого-экономической эффективности; графическое моделирование; корреляционный анализ; регрессионный анализ.

Для цитирования: Бенц Д. С. Моделирование эколого-экономической эффективности Уральского региона // Journal of New Economy. 2019. T. 20, № 4. C. 70-87. DOI: 10.29141/20731019-2019-20-4-4

Дата поступления: 13 мая 2019 г.

\section{Введение}

$Э$ кономический рост, экономическое развитие - это цели, на которые и национальная экономика, и экономика регионов держала ориентир несколько последних десятилетий. Гонка за экономическим ростом привела к целому ряду негативных последствий в экологическом отношении. По оценкам экспертов, величина экономического ущерба от загрязнений воды и атмосферы составляет 6-15 \% ВВП страны. С другой стороны, Россия считается экологическим донором мира, так как обеспечивает до 10 \% биосферной 
устойчивости. Однако в 40 субъектах РФ свыше половины городского населения проживает в условиях высокой загрязненности воздуха ${ }^{1}$. При этом большинство населения России проживает на территории промышленных регионов. «Самый» промышленный регион - Уральский федеральный округ [Бенц, Капкаев, 2018], который является объектом исследования. По данным Росстата, суммарная доля промышленного производства на конец 2016 г. в Уральском регионе составила 52,4\%².

Цель исследования - определение темпа роста промышленного производства, не противоречашего концепции эколого-экономической эффективности. Для этого автором разработана методика определения оптимального темпа роста промышленного производства, которая базируется на графическом моделировании. Предлагается построить две функции, одна из которых будет отражать зависимость экономической эффективности от темпов роста промышленного производства. Вторая функция показывает зависимость экологической эффективности от аналогичного фактора. Совмещение двух функций, как в графическом, так и алгебраическом смысле, позволит найти искомую величину.

Задачи исследования:

- определение связи между показателями экономического роста региона и его экологической эффективностью с применением корреляционного анализа.

- построение регрессионных моделей, одна из которых отражает зависимость экономического роста от ряда показателей, другая - зависимость объемов выброса в атмосферу от показателей экологической эффективности.

Построение регрессий поможет доказать или опровергнуть две гипотезы:

1) зависит ли темп роста номинального валового регионального продукта от темпов роста промышленного производства, численности рабочей силы, инвестиций в основной капитал, среднедушевых денежных доходов населения, затрат на технологические инновации;

2) зависит ли экологическая эффективность от темпов роста промышленного производства, текущих затрат на охрану окружающей среды, инвестиций в основной капитал, направленных на охрану окружающей среды.

Функции, о которых идет речь, будут построены не только в виде множественных, но и в виде парных регрессий. Построение парных регрессий позволит провести наглядное графическое моделирование и достичь заявленной выше цели.

\section{Концепция устойчивого развития}

«Устойчивое развитие» - категория, возникшая не сегодня. Идея о более устойчивой экономике обсуждается десятилетиями. В последние годы дискуссия вокруг устойчивости стала ключевой в обсуждении глобальных проблем. Это обосновывается результатами научных исследований, выявивших деградацию окружающей среды. Согласно Программе $\mathrm{OOH}$ по окружающей среде, достижение устойчивости почти полностью зависит от формирования «правильной» экономики. Итогом Первой всемирной конференции по проблемам окружающей среды (1972 г.) стала Стокгольмская Декларация по окружающей среде, в которой был закреплен термин «устойчивое развитие». В этом же году была принята Программа ООН по окружающей среде (ЮНЕП). В документе провозглашена защита окружающей среды как ключевая концепция Программы, сделан акцент на том,

\footnotetext{
${ }^{1}$ Основы государственной политики в области экологического развития России на период до 2030 года (утв. Президентом РФ 30 апреля 2012 г.). URL: http://base.garant.ru/70169264/

2 Ежегодный статистический сборник «Регионы России». URL: http://www.gks.ru/free_doc/doc_2018/ region/reg-pok18.pdf
} 
что развитие цивилизации и экологические проблемы нельзя рассматривать обособленно друг от друга [Egelston, p. 7].

Прямая связь экономического роста с уровнем бедности и экологическими бедствиями была показана в докладе «Пределы роста» Римского клуба. Аналогичные вопросы были подняты в докладе Комиссии ООН «Наше общее будущее» $(1987 \text { г. })^{1}$, в котором впервые дана формулировка устойчивого развития. В 1996 г. Россия взяла обязательство по переходу к устойчивому развитию, что нашло отражение в Указе Президента РФ № 440 от 1 апреля 1996 г. Далее концепция была представлена в ряде программ $\mathrm{OOH}^{2}$.

«Устойчивое развитие» - категория, более широкая, нежели «экологическая эффективность». Тем не менее одно из фундаментальных направлений устойчивого развития это рост именно экологической эффективности. «Зеленая экономика» - термин, прозвучавший в 1989 г. в новаторском докладе «Проект зеленой экономики», подготовленном группой экономистов-экологов для правительства Соединенного Королевства [Barbier, Markandya, Pearce, 1990]. В 2008 г. этот термин был возрожден. Финансовый кризис и проблемы глобальной рецессии подтолкнули ЮНЕП отстаивать идею «пакетов зеленых стимулов». Концепция «зеленой экономики» стала ключевым шагом к достижению устойчивого развития [Аткиссон, 2012], под которым стали понимать развитие, позволяющее удовлетворять потребности ныне живущих людей, не лишая будущие поколения возможности удовлетворять свои потребности [Медоуз и др., 1991].

В современном мире экологические проблемы обостряются. Уровень загрязненности окружающей среды находится на пределе допустимых границ. Вопросы экологии затрагивают не только биологов, но и остальные сферы научного познания. Тема устойчивого развития является междисциплинарной, ее изучают представители различных наук биологии, экологии, химии. Пристальное внимание этой области уделяют и экономисты. М. Вайнштейн, посвятивший вопросам устойчивого развития более 200 публикаций, проблему устойчивого развития называет «трансдисциплинарной», ментальной [Weinstein, Turner, Ibáñez, 2013; Weinstein, Litvin, Krebs, 2014]. Он делает акцент на необходимости обучить новое поколение мышлению, которое соответствуюет парадигме устойчивого развития. Для создания устойчивого мира необходимо приложить усилия в области технических, экономических, социальных, политических и личностных изменений. Некоторые авторы рассматривают экологические проблемы через призму цены на ресурсы и готовности потребителя платить за эти ресурсы - через поведение потребителя [Dasgupta A., Dasgupta P., 2017]. Авторы изучают нормы потребления и социально направленные предпочтения и показывают, что выстраивание связей между социологическими и поведенческими экономическими подходами к исследованию поведения потребителя может дать существенные результаты в области экономического анализа, особенно экологической политики [Dasgupta P. et al., 2016].

Проблема устойчивого развития стала актуальной, когда появилось понимание того, что ускорение темпов экономического роста несет в себе отрицательные последствия в виде колоссального увеличения выбросов в окружающую среду, невозможности восполнить потребленные ресурсы, парниковых эффектов [Ananda, Hampf, 2015]. Рост производства, сопровождающегося загрязнениями, приводит к существенному увеличению и потребляемых ресурсов. В частности, зависимость потребляемой энергии от объема ВНП на душу населения описывается следующим уравнением [Brown et al., 2011, p. 20]:

\footnotetext{
${ }^{1}$ Наше общее будущее: доклад Международной комиссии по окружающей среде и развитию (МКОСР). URL: http://устойчивоеразвитие.pф/files/monographs/OurCommonFuture-introduction.pdf

${ }^{2}$ The Future we want. URL: http://www.un.org/disabilities/documents/rio20_outcome_document_complete.pdf; Sustainable Development Goals. URL: https://sustainabledevelopment.un.org/post2015/transformingourworld
} 


$$
y=4,06 x^{0.76}\left(r_{2}=0,76\right),
$$

где $y$ - объем потребляемой энергии на душу населения, Вт; $x$ - объем ВНП на душу населения. Выборкой для построения регрессии послужили 50 стран, исследуемый период - 1980-2003 гг. Уравнение говорит о том, что на каждые дополнительные 1000 дол. роста ВНП на душу населения рост потребления электроэнергии также на душу населения составляет 400-500 Вт.

По мнению отечественных ученых, в частности Н. Н. Моисеева [2013], термин «устойчивое развитие» близок к термину «ноосфера». Широкое распространение получил термин «зеленая экономика».

Международная торговая палата (ICC) определяет «зеленую экономику» как экономику, в которой экономический рост и экологическая ответственность «работают» совместно, поддерживая прогресс в социальном развитии. Термин «зеленая экономика» впервые был озвучен в 1989 г. в докладе для правительства Соединенного Королевства «Проект зеленой экономики» [Barbier, Markandya, Pearce, 1990]. В 2008 г. этот термин возродился. В контексте финансового кризиса и проблем глобальной рецессии ЮНЕП отстаивала идею «пакетов зеленых стимулов» и определила конкретные области, в которых крупномасштабные государственные инвестиции могли бы начать «зеленую экономику» [Аткиссон, 2012].

В основе теории «зеленой экономики» лежат три ключевые предпосылки: невозможно бесконечно расширять сферу влияния в ограниченном пространстве; нельзя требовать удовлетворения бесконечно растущих потребностей в условиях ограниченности ресурсов; все на поверхности Земли является взаимосвязанным [Смагулова, Муханова, Мусаева, 2015].

Концепция устойчивого развития вышла далеко за рамки экологической составляющей. А. Г. Дементьева и М. И. Соколова [2018], исследуюя связь вопросов социальноэтического маркетинга и устойчивого развития крупного бизнеса, пришли к выводу, что развитие крупного бизнеса становится возможным только при условии выработки стратегических программ, нацеленных на достижение запланированных показателей в том числе в экологической деятельности. Внедряются стандарты, содержащие показатели, позволяющие оценить степень ответственности крупного бизнеса. Такие стандарты все чаще содержат индикаторы устойчивого развития [Kanie, Zondervan, Betsill, 2011]. Корпоративные ценности и принципы устойчивого развития должны беть неразрывными. Все чаще говорят о том, что рост капитализации крупного бизнеса возможен только при условии достижения баланса интересов всех участников в отношении экономического, социального и экологического аспектов [Sachs, 2015, p. 443].

В России началом перехода к концепции устойчивого развития можно считать утверждение Указом Президента соответствующего документа, в котором постулируются обязательства страны по переходу к устойчивому развитию [Бобылев, 2017]. В экономической литературе не просто констатируется значимость экологической составляющей, а предпринимаются попытки количественно оценить устойчивое развитие. В частности, С. Бобылев, Н. Зубаревич, С. Соловьева [2015] разработали для России некий индекс устойчивого развития, который агрегирует и позволяет сбалансированно учитывать экономические, социальные и экологические показатели.

В контексте регионального развития все чаще в современной литературе встречаются категории «эколого-экономическая эффективность» или «экоэффективность». Связь регионального развития и эколого-экономической эффективности находится в поле зрения ученых крупных мировых экономик. Интересен результат, полученный учеными при исследовании экономики китайских земель. Проведя глубокий количественный 
анализ, они пришли к выводу, что источником роста эффективности землепользования является рост доходов сельского, а не городского населения [Wang et. al., 2018].

Исследование автора не является радикально новым. Новое оно в смысле попытки соотнести экономический рост с экологическими потерями и «нащупать» так называемый допустимый рост без существенных потерь. Можно найти немало исследований, посвященных количественной оценке эколого-экономической эффективности. В настоящее время ученые рассматривают экологическую эффективность как измеритель устойчивого развития. И как правило, этот измеритель отражает некий суммарный эффект от эффективности применяемых ресурсов, биологическую, экологическую и социальную эффективности.

Рассмотрев динамику ресурсной, экологической и биологической эффективности Китая 1978-2016 гг., из всех названных величин эффективности ученые констатировали падение экологической эффективности вплоть до 1990 г. [Yang L., Yang Y., 2019]. Экологическая эффективность представлена U-образной кривой: рост ее наблюдается с 1990 по 2016 г., благодаря чему более быстрым темпом начинает расти общая экоэффективность.

Наряду с категорией «экоэффективность» появилась и категория «экодостаточность». Современные компании должны формировать стратегию экоэффективности и экодостаточности. Только тогда они смогут функционировать в русле концепции устойчивого развития. Причем стратегия экодостаточности должна поддерживаться некоммерческими агентами [Heikkurinen, Young, Morgan, 2019].

Швеция является одной из стран, где особое внимание уделяется городскому планированию. Говоря об устойчивом развитии, представители шведской науки пошли дальше - в модель современного города вписали и концепцию устойчивого развития, и концепцию управления знаниями [Shahraki, 2019].

В заключение обзора исследований в области устойчивого развития можно смело утверждать, что их великое множество. Это исследования, которые не ограничиваются изучением лишь вредных выбросов. Это исследования и эффективного землепользования, и энергосбережения, и градостроительства, и экономики знаний, и финансовой, биологической, социальной и экологической эффективности. Это исследования, которые оперируют множеством терминов: есо-efficient, eco-efficiency indicator, efficiency measurement, energy efficiency, industrial ecology, sustainable, sustainability, sustainable management, sustainable performance, sustainable indicator [Caiado, Dias, Mattos etc., 2017].

\section{Методологические аспекты эколого-экономической эффективности}

Экономический рост и экологическая эффективность находятся в противоречии. Это ключевая идея автора. Предлагаем две группы показателей: одна иллюстрирует экономический рост, вторая - экологическую эффективность. На рис. 1 изображена связь исследуемых показателей.

Для определения количественной связи между экономическим ростом и экологической эффективностью можно использовать коэффициент корреляции. Если говорить о функциональной зависимости, то автор предлагает экономический рост $\mathrm{E}_{1}$ (темп роста ВРП) рассматривать как некую функцию, показывающую зависимость от регрессоров/ факторов. В качестве зависимой переменной, отражающей экономический рост, предлагаем использовать темп роста валового регионального продукта (ВРП):

$$
E_{1}=f\left(X_{1}, X_{2}, X_{3}, X_{4}, X_{5}, X_{6}, \text { etc. }\right) \text {, }
$$

где $X_{1} \ldots X_{6}$ - факторы экономического роста. 


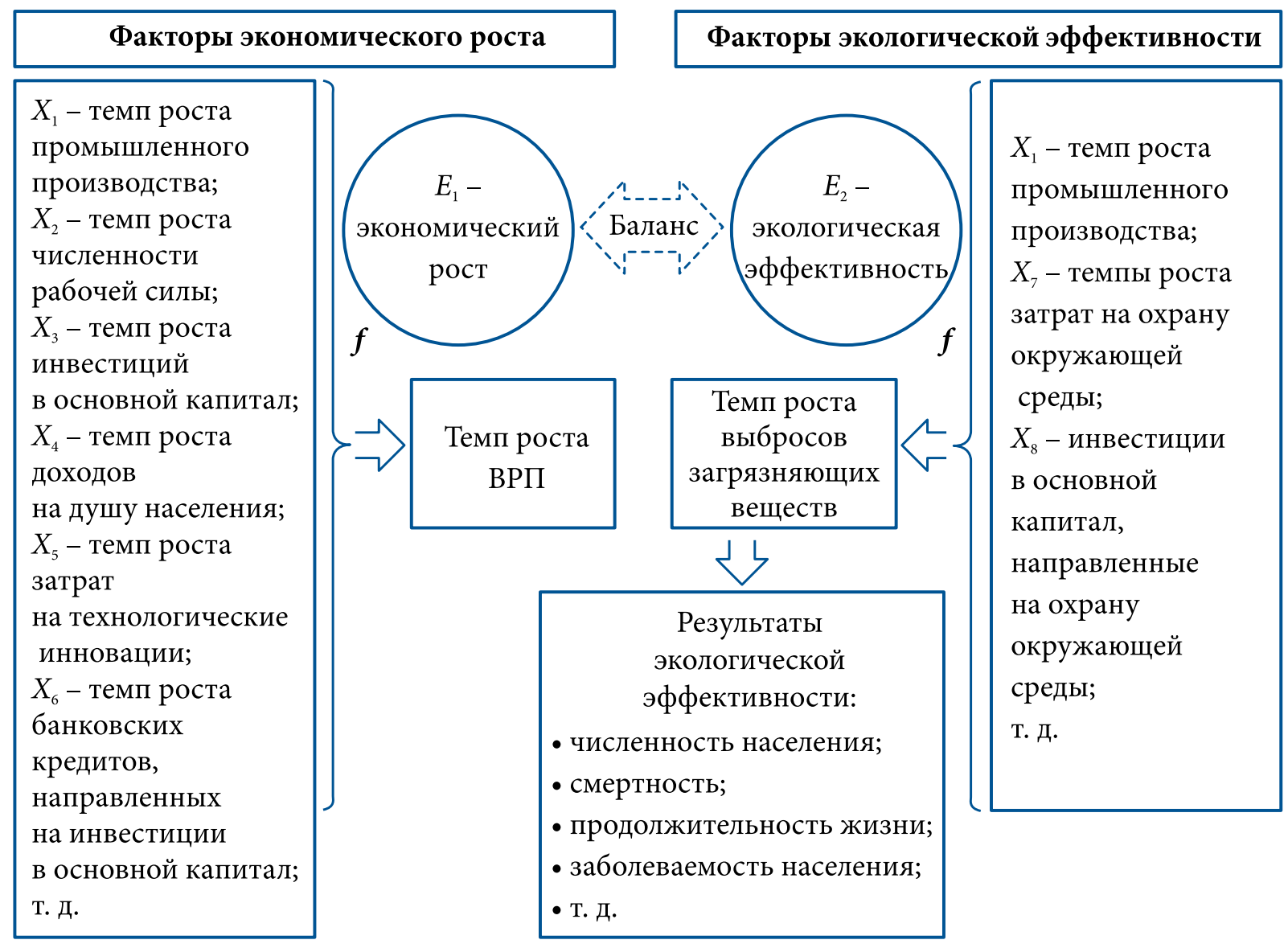

Рис. 1. Связь показателей экономического роста и экологической эффективности

Fig. 1.The connection between indicators of economic growth and environmental efficiency

Под экологической эффективностью $E_{2}$ предлагаем понимать показатель, обратный темпам роста загрязнений:

$$
E_{2}=\frac{1}{\text { Темп роста выбросов в атмосферу }} .
$$

Экологическую эффективность следует рассматривать шире, чем просто ориентируясь на темпы роста загрязнений. Однако нашей задачей является количественная оценка таковой, поэтому мы введем это упрощение. Кроме того, последствия, которые могут стать результатом экологической эффективности, и отраженные на рис. 1 численность населения, смертность, продолжительность жизни, заболеваемость, также можно представить в виде отдельной математической функции.

Экологическую эффективность $E_{2}$ тоже можно представить как функцию, зависящую от ряда факторов:

$$
E_{2}=f\left(X_{1}, X_{7}, X_{8}, \text { etc. }\right) \text {, }
$$

где $X_{1}, X_{7}, X_{8}$ - факторы экологической эффективности.

В качестве гипотезы предлагаем следующую концепцию. На рис. 2 представлены кривая $E_{1}$ - зависимость экономического роста и кривая $E_{2}-$ зависимость экологической эффективности от темпов роста промышленного производства. Предположим, что существует некий оптимальный темп роста промышленного производства, который находится на пересечении двух кривых. 
Кривая общей эффективности $T E$ показывает сумму кривых $E_{1}$ и $E_{2}$. Оптимальный уровень роста промышленного производства $i_{\text {opt }}$ в этом случае будет находиться на уровне максимальной суммарной эффективности $T E_{\text {max }}$.

Если регион наращивает темпы промышленного производства сверх оптимального размера, то это приводит к снижению экологической эффективности. Допустим, что экономический рост сверх оптимального уровня возможен, но только при условии дополнительного инвестирования в экотехнологии. Можно предположить, что эластичность кривой $E_{2}$ зависит именно от инвестиций в экотехнологии. Уровень экологической эффективности будет снижаться меньшим темпом в условиях эффективно действующих экотехнологий.

На рис. 3 показано изменение угла наклона кривой $E_{2}$, обусловленное изменением эластичности, что приведет к росту оптимального индекса $i_{\text {opt }}$.

Идея, представленная на рис. 2 и 3, отражает однофакторную концепцию, в то время как функции в формулах (1) и (3) являются многофакторными. Тем не менее, если ввести в модель предпосылку о том, что темпы роста ВРП и экологической эффективности максимально коррелируют именно с темпом роста промышленного производства, то графики на рис. 2 и 3 в большей мере будет отражать сложившуюся в регионе реальность.

\section{Методика оценки экономико-экологической эффективности}

Методика оценки оперирует показателями, приведенными на рис. 1 , и предполагает применение следующего инструментария:

1. Корреляционный анализ - расчет коэффициента парной корреляции показателей (рис. 1). На начальном этапе он позволит определить наличие или отсутствие связи между исследуемыми величинами, а также тесноту связи.

2. Регрессионный анализ - построение функциональных зависимостей, предложенных в формулах (1) и (3).

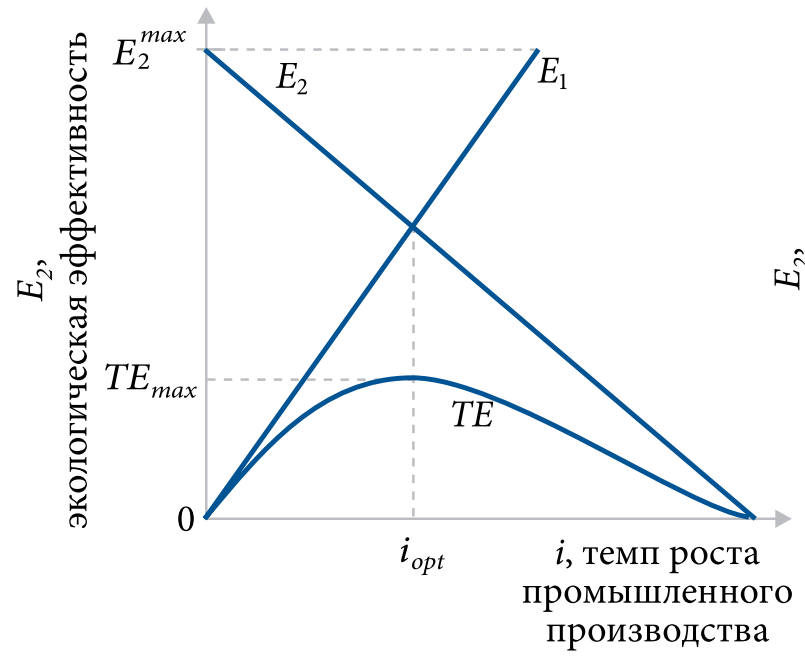

Рис. 2. Зависимость экономического роста $\left(E_{1}\right)$ и экологической эффективности $\left(E_{2}\right)$ от темпов роста промышленного производства $(i)$

Fig. 2. Dependence of the economic growth $\left(E_{1}\right)$ and environmental efficiency $\left(E_{2}\right)$ on growth rates of industrial production (i)

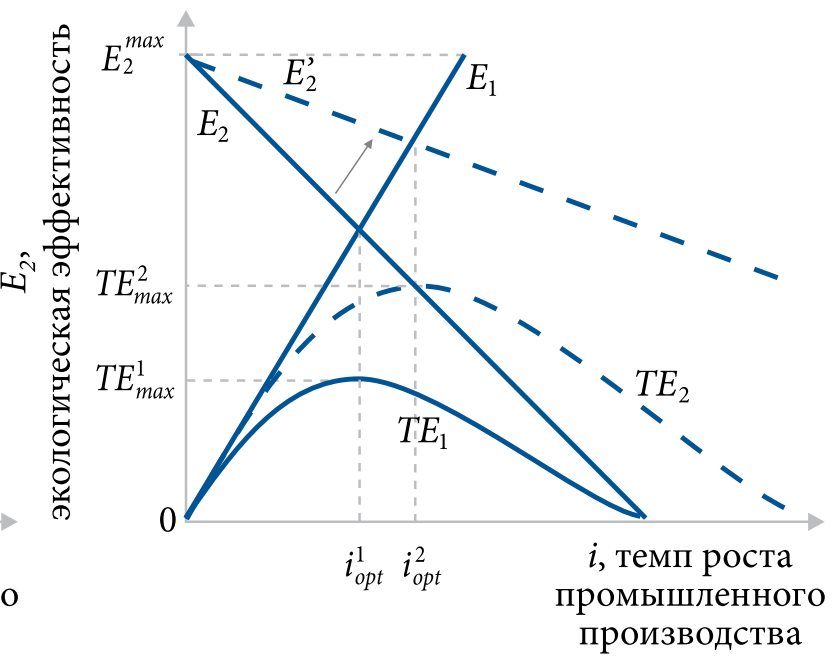

Рис. 3. Изменение оптимального темпа роста промышленного производства $\left(i_{\text {opt }}\right)$ в результате изменения эластичности экологической эффективности $\left(E_{2}\right)$

Fig. 3. Changes in the optimum growth rate of industrial production $\left(i_{\text {opt }}\right)$ as a result of changes in the elasticity of environmental efficiency $\left(E_{2}\right)$ 
Эмпирические исследования позволили определить, что функциональная зависимость вида (4) наилучшим образом описывает исходные данные, фигурируемые в качестве переменных в зависимости (1):

$$
E_{1}=A \cdot X_{1}^{\alpha} \cdot X_{2}^{\beta} \cdot X_{3}^{\gamma} \cdot X_{4}^{\delta} \cdot X_{5}^{\lambda},
$$

где $E_{1}$ - темп роста номинального ВРП (в текущих ценах); $X_{1}$ - темп роста промышленного производства; $X_{2}$ - темп роста численности рабочей силы; $X_{3}$ - темп роста инвестиций в основной капитал; $X_{4}$ - темп роста среднедушевых денежных доходов населения; $X_{5}$ - темп роста затрат на технологические инновации; $A, \alpha, \beta, \gamma, \delta, \lambda$ - параметры функции.

Функция (1), наряду с пятью факторами, в качестве шестого предполагала темп роста банковских кредитов, направленных на инвестиции в основной капитал. Тем не менее было принято решение исключить этот фактор из функции по двум причинам. Bo-первых, ранее автор неоднократно проводил количественные исследования факторов экономического роста региона [Бархатов, Бенц, 2018], и ни одно исследование не показало высокой эластичности экономического роста в отношении прироста банковских кредитов, направленных на инвестиции в основной капитал. Во-вторых, статистика по банковским кредитам доступна лишь с 2002 г., в то время как статистика по всем остальным пяти факторам доступна за более длительный период - с 1996 г. Для роста качества модели необходима максимально расширенная выборка.

Функцию (3) будем строить следующим образом:

$$
E_{2}=A \cdot X_{1}^{\varepsilon} \cdot X_{7}^{\varphi} \cdot X_{8}^{\mu},
$$

где $E_{2}$ - экологическая эффективность (величина, обратная темпу роста загрязняющих выбросов в атмосферу); $X_{1}$ - темп роста промышленного производства; $X_{7}$ - темп роста текущих затрат на охрану окружающей среды; $X_{8}$ - темп роста инвестиций в основной капитал, направленных на охрану окружающей среды; $A, \varepsilon, \varphi, \mu$ - параметры функции.

Графическое моделирование предполагает построение двух графических моделей - $E_{1}$ и $E_{2}$ (см. рис. 2). Обе модели являются однофакторными (с целью построения графиков на плоскости). Функция $E_{1}$ показывает зависимость темпов роста валового регионального продукта от темпов роста промышленного производства $X_{1}$, функция $E_{2}-$ зависимость экологической эффективности от темпов роста промышленного производства.

Построение двух графиков позволит найти некий оптимальный темп роста промышленного производства $i_{\text {opt }}$. Каждый график описывает некую функциональную зависимость. Найти заявленный оптимум можно, если приравнять две полученные функции. Гипотеза автора следующая: если темпы роста региона превышают некий оптимум, то это будет означать последующее падение экологической эффективности даже при дальнейшем росте ВРП.

\section{Эмпирические результаты исследования}

Исходными данными для оценки стали годовые значения показателей, характеризующих Уральский федеральный округ и публикуемых Росстатом и ООО «Первое независимое рейтинговое агентство» (FIRA.RU). Переменные $E_{1}, E_{2}, X_{1}, X_{2}, X_{3}, X_{4}, X_{5}$ доступны в ежегодных сборниках «Регионы России», переменные $X_{7}, X_{8}$ - в базе данных FIRA.RU. Временной диапазон составил период с 1996 по 2016 г., выборка - 21 наблюдение.

Расчет коэффициентов корреляции между темпом роста валового регионального продукта $E_{1}$ и темпом роста промышленного производства $X_{1}$, темпом роста численности рабочей силы $X_{2}$, темпом роста инвестиций в основной капитал $X_{3}$, темпом роста 
доходов на душу населения $X_{3}$, темпом роста затрат на технологические инновации $X_{5}$ дал следующие результаты (табл. 1). Выборкой для анализа стали указанные величины за период 1996-2016 гг.

\section{Таблица 1. Корреляционный анализ темпов роста номинального и реального ВРП Уральского региона и темпов роста факторов производства}

Table 1. Correlation between growth rates of nominal and real GRP of the Ural region and growth rates of factors

\begin{tabular}{|l|c|c|}
\hline \multicolumn{1}{|c|}{ Фактор роста ВРП } & \multicolumn{2}{|c|}{$\begin{array}{c}\text { Значение коэффициента } \\
\text { корреляции }\end{array}$} \\
\cline { 2 - 3 } & $\begin{array}{c}\text { Темп роста } \\
\text { номинального } \\
\text { ВРП }\end{array}$ & $\begin{array}{c}\text { Темп роста } \\
\text { реаного } \\
\text { ВРП }\end{array}$ \\
\hline Темп роста промышленного производства $\left(X_{1}\right)$ & 0,47 & 0,32 \\
\hline Темп роста численности рабочей силы $\left(X_{2}\right)$ & 0,55 & 0,38 \\
\hline Темп роста инвестиций в основной капитал $\left(X_{3}\right)$ & 0,77 & 0,37 \\
\hline Темп роста среднедушевых денежных доходов населения $\left(X_{4}\right)$ & 0,87 & 0,39 \\
\hline Темп роста затрат на технологические инновации $\left(X_{5}\right)$ & 0,25 & $-0,25$ \\
\hline
\end{tabular}

Источник: рассчитано автором по данным Росстата. URL: http://www.gks.ru/free_doc/doc_2018/ region/reg-pok18.pdf)

Из табл. 1 видно, что самые высокие значения коэффициента корреляции характерны для связей «темп роста среднедушевых денежных доходов населения - темп роста номинального ВРП» и «темп роста затрат на технологические инновации - темп роста номинального ВРП». Из этого следует, что ключевые факторы, «толкающие» регион к росту, это были и есть доходы населения, т. е. платежеспособный спрос, и инвестиции в основной капитал.

В дальнейшем будем анализировать темпы роста номинального ВРП, так как они дали наиболее высокие значения корреляции. С одной стороны, исследовать реальный рост - это наиболее правильное решение. С другой стороны, объектом исследования выступают не абсолютные величины, а темпы роста, что нивелирует ценовой фактор (фактор некой инерции). Все остальные величины, за исключением выбросов загрязнений в атмосферу, измеряются в денежных единицах в текущих ценах, поэтому исследуются соизмеримые величины - темпы роста номинальных значений.

Расчет коэффициентов корреляции между темпом роста выбросов в атмосферу, темпом роста промышленного производства $X_{1}$, темпом роста текущих затрат на охрану окружающей среды $X_{7}$ и темпом роста инвестиций в основной капитал, направленных на охрану окружающей среды $X_{8}$, дал результаты, приведенные в табл. 2. Корреляция между темпом роста выбросов в атмосферу и темпом роста промышленного производства рассчитана по данным 1996-2016 гг. Выборка по остальным показателям составила временной диапазон 2005-2016 гг.

Корреляционный анализ позволяет сделать интересный вывод: не так уж тесно связаны темпы роста загрязнений с темпами роста промышленного производства. Можно утверждать, что не только промышленность как таковая является ключевым источником загрязнений. С другой стороны, можно предположить, что не факт роста промышленного производства, а факт его существования может быть ключевой причиной увеличения загрязнений. Год от года производственные фонды устаревают, на смену должны приходить новые экологически эффективные, энергоэффективные технологии. Однако внедрение таковых идет медленно. 


\section{Таблица 2. Корреляционный анализ темпов роста вредных выбросов в атмосферу, текущих затрат на охрану окружающей среды и инвестиций, направленных на охрану окружающей среды (Уральский регион)}

Table 2. Correlation analysis of growth rates of harmful emissions in the atmosphere, current expenditures on environmental protection, and investments directed to environmental protection (a case of the Ural region)

\begin{tabular}{|l|c|}
\hline \multicolumn{1}{|c|}{ Темп роста } & $\begin{array}{c}\text { Значение коэффициента } \\
\text { корреляции между темпом роста } \\
\text { вредных выбросов в атмосферу } \\
\text { и соответствующим показателем }\end{array}$ \\
\hline Валового регионального продукта $E_{1}$ & 0,51 \\
\hline Промышленного производства $X_{1}$ & 0,60 \\
\hline Текущих затрат на охрану окружающей среды $X_{7}$ & 0,62 \\
\hline Инвестиций, направленных на охрану окружающей среды, $X_{8}$ & $-0,13$ \\
\hline Затрат на технологические инновации $X_{5}$ & 0,25 \\
\hline
\end{tabular}

Источник: рассчитано автором по данным Росстата. URL: http://www.gks.ru/free_doc/doc_2018/ region/reg-pok18.pdf) и первого Независимого рейтингового агентства FIRA PRO. URL: https:// pro.fira.ru/search/index.html\#company)

Для построения функции вида (4) использовался прием линеаризации модели с применением натуральных логарифмов, что позволило построить промежуточную линейную функцию. Дескриптивная статистика наблюдаемых переменных для построения множественной линейной функции показана в табл. 3.

\section{Таблица 3. Дескриптивная статистика наблюдаемых переменных для построения} функции вида $\ln \left(E_{1}\right)=\ln (A)+\alpha \ln \left(X_{1}\right)+\beta \ln \left(X_{2}\right)+\gamma \ln \left(X_{3}\right)+\delta \ln \left(X_{4}\right)+\lambda \ln \left(X_{5}\right)$ Table 3. Descriptive statistics of the variables for creation of the function $\ln \left(E_{1}\right)=\ln (A)+\alpha \ln \left(X_{1}\right)+\beta \ln \left(X_{2}\right)+\gamma \ln \left(X_{3}\right)+\delta \ln \left(X_{4}\right)+\lambda \ln \left(X_{5}\right)$

\begin{tabular}{|c|c|c|c|c|c|}
\hline \multirow{2}{*}{ Переменная } & \multirow{2}{*}{$\begin{array}{l}\text { Количество } \\
\text { наблюдений }\end{array}$} & \multirow{2}{*}{$\begin{array}{c}\text { Среднее } \\
\text { значение } \\
\end{array}$} & \multirow{2}{*}{$\begin{array}{c}\text { Стандартная } \\
\text { ошибка }\end{array}$} & \multicolumn{2}{|c|}{ Значение } \\
\hline & & & & минимальное & максимальное \\
\hline $\begin{array}{l}\text { Натуральный логарифм темпа } \\
\text { роста ВРП }\end{array}$ & 21 & 0,1707 & $0,0284^{*}$ & $-0,1083$ & 0,5073 \\
\hline $\begin{array}{l}\text { Натуральный логарифм темпа } \\
\text { роста промышленного произ- } \\
\text { водства }\end{array}$ & 21 & 0,0241 & 0,3863 & $-0,0954$ & 0,0980 \\
\hline $\begin{array}{l}\text { Натуральный логарифм темпа } \\
\text { роста численности рабочей } \\
\text { силы }\end{array}$ & 21 & 0,0010 & 0,9946 & $-0,0279$ & 0,0543 \\
\hline $\begin{array}{l}\text { Натуральный логарифм темпа } \\
\text { роста инвестиций в основной } \\
\text { капитал }\end{array}$ & 21 & 0,1782 & 0,1230 & $-0,2495$ & 0,7747 \\
\hline $\begin{array}{l}\text { Натуральный логарифм темпа } \\
\text { роста }\end{array}$ & 21 & 0,1793 & 0,2079 & $-0,0134$ & 0,4929 \\
\hline $\begin{array}{l}\text { Натуральный логарифм темпа } \\
\text { роста }\end{array}$ & 21 & $-0,0618$ & 0,0086 & $-7,0734$ & 2,4006 \\
\hline
\end{tabular}

Примечание: * ${ }^{*}$ тандартная ошибка свободного члена ( $Y$-пересечение)

Регрессионный анализ - построение функции (4) - позволил получить модель следующего вида: 
$E_{1}=1,028 \cdot X_{1}^{0,878} \cdot X_{2}^{1,529} \cdot X_{3}^{0,206} \cdot X_{4}^{0,461} \cdot X_{5}^{-0,013}$

Нормированный коэффициент детерминации составил 0,79. F-статистика отвергает гипотезу о незначимости полученного уравнения. В соответствии $\mathrm{c}$ t-статистикой значимыми получились степени $\alpha$ и $\delta(\alpha=0,878 ; \delta=0,461)$. При этом воздействие темпа роста промышленного производства $X_{1}$ на рост валового регионального продукта $E_{1}$ оказывается в два раза сильнее воздействия денежных доходов населения $X_{4}$. Самой высокой эластичностью обладает темп роста рабочей силы в регионе $(\beta=1,529)$, но соответствующий параметр уравнения оказался незначимым, что не дает нам права сделать столь однозначный вывод.

Аналогично для построения функции вида (5) применялся метод линеаризации модели с целью построения множественной линейной регрессии. Дескриптивная статистика наблюдаемых переменных для построения линейной функции показана в табл. 4.

Построение функции вида (5) дало следующий результат:

$$
E_{2}=1,109 \cdot X_{1}^{0,374} \cdot X_{7}^{1,203} \cdot X_{8}^{-0,048} .
$$

Несмотря на значимость полученного уравнения (в соответствии с F-статистикой), все степени уравнения $\varepsilon, \varphi, \mu$ оказались незначимыми (в соответствии с $t$-статистикой), только параметр $A=1,109$ оказался значимым.

Если отвлечься от незначимости полученных степеней, то наибольшей эластичностью обладает фактор «темп роста текущих затрат на охрану окружающей среды». Чем

\section{Таблица 4. Дескриптивная статистика наблюдаемых переменных для построения функции вида $\ln \left(E_{2}\right)=\ln (A)+\varepsilon \ln \left(X_{1}\right)+\varphi \ln \left(X_{7}\right)+\mu \ln \left(X_{8}\right)$}

Table 4. Descriptive statistics of the variables for creation the function $\ln \left(E_{2}\right)=\ln (A)+\varepsilon \ln \left(X_{1}\right)+\varphi \ln \left(X_{7}\right)+\mu \ln \left(X_{8}\right)$

\begin{tabular}{|c|c|c|c|c|c|}
\hline \multirow{2}{*}{ Переменная } & \multirow{2}{*}{$\begin{array}{l}\text { Количество } \\
\text { наблюдений }\end{array}$} & \multirow{2}{*}{$\begin{array}{r}\text { Среднее } \\
\text { значение }\end{array}$} & \multirow{2}{*}{\begin{tabular}{|c|} 
Стандартная \\
ошибка
\end{tabular}} & \multicolumn{2}{|c|}{ Значение } \\
\hline & & & & минимальное & максимальное \\
\hline $\begin{array}{l}\text { Натуральный логарифм вели- } \\
\text { чины, обратной темпу роста } \\
\text { выбросов загрязняющих ве- } \\
\text { ществ в атмосферный воздух, } \\
\text { отходящих от стационарных } \\
\text { источников }\end{array}$ & 21 & 0,1193 & $0,0249^{*}$ & $-0,1083$ & 0,3245 \\
\hline $\begin{array}{l}\text { Натуральный логарифм темпа } \\
\text { роста промышленного произ- } \\
\text { водства }\end{array}$ & 21 & 0,0227 & 0,2159 & $-0,3080$ & 0,2571 \\
\hline \begin{tabular}{|l|} 
Натуральный логарифм темпа \\
роста текущих затрат на охра- \\
ну окружающей среды
\end{tabular} & 21 & 0,0088 & 0,6377 & $-0,0954$ & 0,0649 \\
\hline \begin{tabular}{|l|} 
Натуральный логарифм темпа \\
роста инвестиций в основной \\
капитал, направленных на ох- \\
рану окружающей среды
\end{tabular} & 21 & 0,0596 & 0,2378 & $-0,1507$ & 0,2056 \\
\hline $\begin{array}{l}\text { Натуральный логарифм темпа } \\
\text { роста }\end{array}$ & 21 & 0,1793 & 0,2079 & $-0,0134$ & 0,4929 \\
\hline $\begin{array}{l}\text { Натуральный логарифм темпа } \\
\text { роста }\end{array}$ & 21 & $-0,0618$ & 0,0086 & $-7,0734$ & 2,4006 \\
\hline
\end{tabular}

Примечание: *стандартная ошибка свободного члена ( $Y$-пересечение) 
выше темп роста таких затрат, тем выше величина $E_{2}$. Величина $E_{2}$ является обратной по отношению к темпам роста загрязняющих выбросов в атмосферу. Напрашивается очевидный вывод: чем выше темп роста текущих затрат на охрану окружающей среды, тем ниже темп роста загрязнений. Куда меньшая эластичность характерна для степени $\varepsilon=0,378$, что говорит о меньшей связи темпов роста промышленного производства и темпов роста выбросов в атмосферу. В этом смысле и корреляционный анализ дал значение коэффициента корреляции лишь 0,6 (табл. 2). Минимальная связь характерна для степени $\mu=-0,048$, причем отрицательный знак характерен для зависимости величины, обратной темпам роста выбросов в атмосферу, от темпов роста инвестиций, направленных на охрану окружающей среды. А значит, связь между прямыми величинами будет положительной, но тем не менее незначительной, что говорит об отложенном эффекте таких инвестиций.

Следующий этап анализа предполагает построение графиков, представленных на рис. 2. График, отражающий функциональную зависимость темпов роста валового продукта от темпов роста промышленного производства (назовем его график экономической эффективности $E_{1}$ ) показан на рис. 4. Уравнение, наилучшим образом описывающее исходные данные, имеет вид линейной функции (рис. 4).

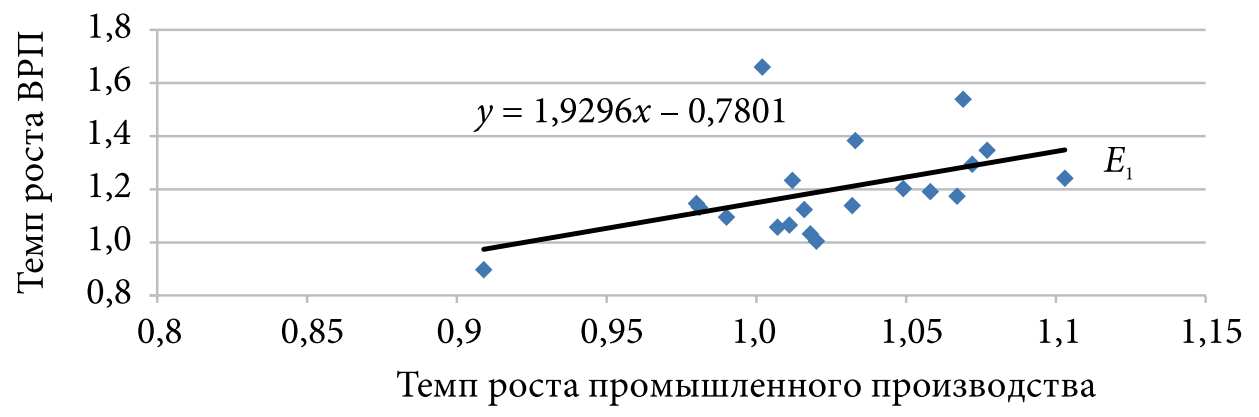

Рис. 4. Графическое моделирование функции экономической эффективности $E_{1}$ Fig. 4. Modeling of economic efficiency function $E_{1}$

На рис. 5 показан график экологической эффективности $E_{2}$, величина которой $E_{2}$ была рассчитана по формуле (2).

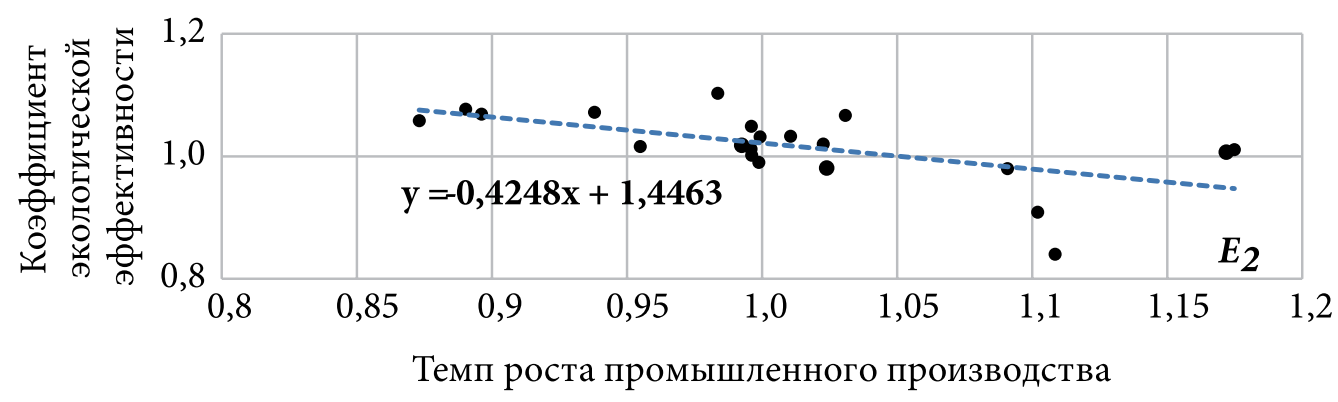

Рис. 5. Графическое моделирование функции экологической эффективности $E_{2}$ Fig. 5. Modeling of environmental efficiency function $E_{2}$

Эмпирическим путем мы получили два уравнения. Уравнение экономической эффективности имеет следующий вид:

$$
y=1,9296 x-0,7801
$$


где $y$ - темп роста валового регионального продукта; $x$ - темп роста промышленного производства.

Уравнение экологической эффективности имеет следующий вид:

$$
y=0,4248 x+1,4463,
$$

где $y$ - темп роста величины, обратной темпу роста вредных выбросов в атмосферу; $x$ - темп роста промышленного производства.

Уравнения (8), (9) были построены на базе временной выборки за 1996-2016 гг.

Приравняв уравнения (8) и (9), найдем оптимальный объем темпов роста промышленного производства:

$$
1,9296 x-0,7801=1,9296 x-0,7801 ; x=0,95 .
$$

Полученное значение меньше единицы говорит не о росте промышленного производства, а о его снижении. Иными словами, если падение ежегодно (при прочих равных условиях) будет составлять величину 5 \%, то это позволит не усугублять экологическую составляющую.

\section{Заключение}

Проведенное исследование позволит сделать ряд выводов. В качестве показателя экономического роста автор взял темп роста номинального валового регионального продукта. Говоря об источниках экономического роста, следует отметить, что несколько отличающиеся результаты дали корреляционный и регрессионный анализы.

Корреляционный анализ показал два ключевых источника: душевой доход населения и инвестиции в основной капитал. Именно между темпами экономического роста региона и темпами роста двух указанных величин была обнаружена наиболее тесная связь.

Регрессионный анализ предполагал построение нелинейной множественной регрессии, которая обнаружила три самых высокоэластичных параметра, определяющих влияние на темпы роста ВРП Уральского региона: темпы роста рабочей силы; темпы роста промышленного производства; темпы роста среднедушевых доходов населения.

В качестве показателя экологической эффективности автором было принято решение взять величину, обратную темпам роста выбросов загрязняющих веществ в атмосферный воздух, отходящих от стационарных источников. Это было обусловлено целями графического моделирования - для получения кривой с отрицательным наклоном, для возможности приравнять две полученные кривые (экономической и экологической эффективности) и найти оптимальный темп роста промышленного производства. Корреляционный анализ экологической эффективности выявил наличие умеренной связи таковой с темпами роста затрат на охрану окружающей среды и с темпами роста промышленного производства. Темп роста валового регионального продукта не так тесно связан с темпами роста выбросов загрязняющих веществ в атмосферу, что говорит о «неисчерпанности» возможностей дальнейшего экономического роста без нанесения вреда атмосферному воздуху.

Регрессионный анализ показал наибольшую эластичность воздействия на экологическую эффективность лишь текущих затрат на охрану окружающей среды. Капитальные затраты (инвестиции в основной капитал), направленные на охрану окружающей среды, большого воздействия на рост экологической эффективности не оказывают.

И наконец, графическое моделирование позволило определить оптимальный темп роста промышленного производства, величина которого составила 0,95. Здесь стоит задуматься: а можно ли дальше закрывать глаза на экологические проблемы Уральского 
региона. При условии такого темпа роста промышленного производства темп роста выбросов составит 0,96. Эту величину можно получить из уравнения (9). С другой стороны, при сохранении прежнего темпа загрязнений можно наращивать темпы промышленного производства в три-четыре раза, но задачей региона является не сохранение темпов выбросов, а снижение их, причем существенное. Следовательно, необходимо постепенно внедрять новые, более совершенные в экологическом плане технологии. Несмотря на сложную экологическую обстановку, многие даже самые неблагоприятные в экологическом смысле регионы имеют положительный опыт переработки отходов [Бархатов, Добровольский, Капкаев, 2015a, 2015b, 2017], поэтому можно утверждать, что устойчивое развитие в России возможно.

\section{Источники}

Аткиссон А. (2012). Как устойчивое развитие может изменить мир. М.: Бином. Лаб. знаний. 455 c.

Бархатов В. И., Бенц Д. С. (2018). Источники роста промышленного региона в Уральском федеральном округе // Вестник Челябинского государственного университета. № 3 (413). С. 19-29.

Бархатов В. И., Добровольский И. П., Капкаев Ю. Ш. (2015а). Рациональное использование природных ресурсов Челябинской области: монография: в 2 ч. Ч1. Челябинск: Изд-во Челяб. гос. ун-та. 282 с.

Бархатов В. И. Добровольский И. П., Капкаев Ю. Ш. (2015b). Рациональное использование природных ресурсов Челябинской области: монография: в 2 ч. Ч2. Челябинск: Изд-во Челяб. гос. ун-та. 265 с.

Бархатов В. И., Добровольский И. П., Капкаев Ю. Ш. (2017). Отходы производств и потребления - резерв строительных материалов: монография. Челябинск: Изд-во Челяб. гос. ун-та. 477 с.

Бенц Д. С., Капкаев Ю. Ш. (2018). Устойчивое развитие региона: эколого-экономические аспекты // Научная парадигма цивилизации в XXI веке: капитализм, социализм и четвертая технологическая революция: сб. докл. Десятого междунар. конгресса передовых наук: Челябинск: Изд-во Челяб. гос. ун-та. 101 с.

Бобылев С. (2017). Устойчивое развитие: парадигма для будущего // МЭиМО. Т. 61, № 3. C. $107-113$.

Бобылев С., Зубаревич Н., Соловьева С. (2015). Вызовы кризиса: как измерять устойчивость развития? // Вопросы экономики. №1. С. 147-160.

Дементьева А. Г., Соколова М. И. (2018). Концепция устойчивого развития и социально-этический маркетинг // Известия Уральского государственного экономического университета. Т. 19, № 5. С. 5-15. DOI: 10.29141/2073-10192018-19-5-1.

Медоуз Д. Х., Медоуз Д. А., Рэндерс Й., Беренс В. В. (1991). Пределы роста. М.: МГУ. 207 с.

Моисеев Н. Н. (2013). Ноосфера Вернадского и принцип коэволюции // Вестник экологического образования в России. Т. 1, № 67. С. 4-7.

Смагулова Ж. Б., Муханова А. Е., Мусаева Г. И. (2015). Анализ мирового опыта перехода к зеленой экономике: предпосылки и направления // Международный журнал прикладных и фундаментальных исследований. № 1-1. С. 92-96.

Ananda J., Hampf B. (2015). Measuring environmentally sensitive productivity growth: An application to the urban water sector. Ecological Economics, vol. 116, pp. 211-219. DOI: https://doi.org/10.1016/j. ecolecon.2015.04.025.

Barbier E. B., Markandya A., Pearce D. W. (1990). Environmental sustainability and cost-benefit analysis. Environment and Planning, no. 22, pp. 1259-1266. DOI: 10.1068/a221259.

Brown J., Burnside W., Davidson A., DeLong J., Dunn W., Hamilton M., ... Zuo W. (2011). Energetic limits to economic growth. Bioscience, vol. 61, no. 1, pp. 19-26. DOI: 10.1525/bio.2011.61.1.7.

Caiado R., Dias R., Mattos L., Quelhas O., Filho W. (2017). Towards sustainable development through the perspective of eco-efficiency - A systematic literature review. Journal of Cleaner Production, vol. 165, pp. 890-904. DOI: https://doi.org/10.1016/j.jclepro.2017.07.166. 
Daly H., Farley J. (2004). Ecological economics: Principles and applications. Washington, DC: Island Press. $484 \mathrm{p}$.

Dasgupta A., Dasgupta P. (2017). Socially embedded preferences, environmental externalities, and reproductive rights. Population and Development Review, no. 43 (3), pp. 405-441. DOI: 10.1111/ padr. 12090.

Dasgupta P., Southerton D., Ulph A., Ulph, D. (2016). Consumer behaviour with environmental and social externalities: Implications for analysis and policy. Environmental and Resource Economics, vol. 65, no. 1, pp. 191-226. DOI: 10.1007/s10640-015-9911-3.

Egelston A. (2013). Sustainable development: A history. N.Y.; L.: Springer. 118 p.

Heikkurinen P., Young W., Morgan E. (2019). Business for sustainable change: Extending eco-efficiency and eco-sufficiency strategies to consumers. Journal of Cleaner Production, vol. 218, pp. 656-664. DOI: https://doi.org/10.1016/j.jclepro.2019.02.053.

Kanie N., Zondervan R., Betsill M. (2011). New visions of sustainable development governance. United Nation University. Available at: https:/unu.edu/publications/articles/new-visions-of-sustainable-development-governance.html

Sachs J. D. (2015). The age of sustainable development. Columbia University Press. $544 \mathrm{p}$.

Shahraki A. A. (2019). Sustainable regional development through knowledge networks: Review of case studies. Frontiers of Architectural Research. DOI: https://doi.org/10.1016/j.foar.2019.04.004.

Wang Zh., Chen J., Zheng W., Deng X. (2018). Dynamics of land use efficiency with ecological intercorrelation in regional development. Landscape and Urban Planning, vol. 177, pp. 303-316. DOI: https:// doi.org/10.1016/j.landurbplan.2017.09.022

Weinstein M. P., Turner E. R., Ibáñez C. (2013). The global sustainability transition: It is more than changing light bulbs. Sustainability: Science, Practice, \& Policy, vol. 9, pp. 4-15.

Weinstein M. P., Litvin S. Y., Krebs J. M. (2014). Restoration ecology: Ecological fidelity, restoration metrics, and a systems perspective. Ecological Engineering, no. 65, pp. 71-87.

Yang L., Yang Y. (2019). Evaluation of eco-efficiency in China from 1978 to 2016: Based on a modified ecological footprint model. Science of the Total Environment, vol. 662, pp. 581-590. DOI: https://doi. org/10.1016/j.scitotenv.2019.01.225.

\section{Информация об авторе}

Бенц Дарья Сергеевна, кандидат экономических наук, доцент, доцент кафедры экономики отраслей и рынков Челябинского государственного университета; 454001, РФ, г. Челябинск, ул. Братьев Кашириных, 129

Контактный телефон: +7 (351) 799-71-46, e-mail: benz@csu.ru

Daria S. Benz Chelyabinsk State University, Chelyabinsk, Russia

\section{Modelling of environmental and economic efficiency: A case of the Ural region}

Abstract. The race for economic growth has its price, and regrettably, leads to negative ecological consequences. A recent economic slowdown in the Ural region also has been accompanied with some serious environmental problems. Against such a background, the paper attempts to identify the growth rates of industrial production that comply with the concept of environmental 
and economic efficiency. The methodological basis of the research is the new classical economics according to which the economic growth can be described using the production function reflecting the dependence of the output sold on the production factors involved. For the purposes of the research, the author expands the number of variables and supplements labour and capital, the classical independent variables, with industrial output, average per capita income, and expenditures on technological innovations. According to the findings of the correlation analysis, the strongest correlation is between the growth rates of gross regional product and the growth rates of average per capita income and investments into fixed capital. Additionally, the findings reveal a moderate correlation between the growth rates of the emission of pollutants into the atmosphere and the growth rates of industrial production and the growth of the current expenditures on environmental protection. The author constructs four regressions. Two models represent multiple nonlinear regression; another two show pair linear dependence. The first model reflects the dependence of economic growth rates on the factors mentioned above. The second regression, also being a multiple nonlinear one, shows the dependence of growth rates of harmful emissions into the atmosphere on three factors: growth rates of industrial production, current and capital expenditures on environmental protection. In the pair linear regressions, the independent variable is the growth rates of industrial production. The dependent variables are, in the first case, the growth rates of gross regional product, and in the second case, environmental efficiency coefficient. In line with the findings, the optimum growth rate of industrial production, at which the harmful emissions into the atmosphere can decrease by $4 \%$ equals to 0.95 .

Keywords: regional economic growth; regional environmental efficiency; Ural region; concept of environmental and economic efficiency; modeling; correlation analysis; regression analysis.

For citation: Benz D. S. Modelirovanie ekologo-ekonomicheskoy effektivnosti Ural'skogo regiona [Modelling of environmental and economic efficiency: A case of the Ural region]. Journal of New Economy, 2019, vol. 20, no. 4, pp. 70-87. DOI: 10.29141/2073-1019-2019-20-4-4

Received May 13, 2019.

\section{References}

Atkisson A. (2012). Kak ustoychivoe razvitie mozhet izmenit' mir [How sustainable development can change the world]. Moscow: Binom. Laboratoriya znaniy Publ. 455 p. (in Russ.)

Barkhatov V. I., Benz D. S. (2018). Istochniki rosta promyshlennogo regiona v Ural'skom federal'nom okruge [Sources of economic growth in industrial regions in the Ural Federal District]. Vestnik Chelyabinskogo gosudarstvennogo universiteta $=$ Bulletin of the Chelyabinsk State University, no. 3 (413), pp. 19-29. (in Russ.)

Barkhatov V. I., Dobrovolskiy I. P., Kapkaev Yu. Sh. (2015). Ratsional'noe ispol'zovanie prirodnykh resursov Chelyabinskoy oblasti. Chast 1 [The rational use of natural resources of the Chelyabinsk oblast. Part 1]. Chelyabinsk: Chelyabinsk State University. 282 p. (in Russ.)

Barkhatov V. I., Dobrovolskiy I. P., Kapkaev Yu. Sh. (2015). Ratsional'noe ispol'zovanie prirodnykh resursov Chelyabinskoy oblasti. Chast 2 [The rational use of natural resources of the Chelyabinsk oblast. Part 2]. Chelyabinsk: Chelyabinsk State University. 265 p. (in Russ.)

Barkhatov V. I., Dobrovolskiy I. P., Kapkaev Yu. Sh. (2017). Otkhody proizvodstv i potrebleniya - rezerv stroitel'nykh materialov [Production and consumption waste as reserves of construction materials]. Chelyabinsk: Chelyabinsk State University. 477 p. (in Russ.)

Benz D. S., Kapkaev Yu. Sh. (2018). Regional sustainable development: environmental and economic aspects. Sbornik annotatsii dokladov Desyatogo mezhdunarodnogo kongressa peredovykh nauk "Nauchnaya paradigma tsivilizatsii $v$ XXI veke: kapitalizm, sotsializm $i$ chetvertaya tekhnologicheskaya revolyutsiya" [Proc. 10 $0^{\text {th }}$ Int. Congress "Scientific Paradigm of Civilization in the 21st Century: Capitalism, 
Socialism and the Fourth Technological Revolution".] Chelyabinsk: Chelyabinsk State University. 101 p. (in Russ.)

Bobylev S. (2017). Ustoychivoe razvitie: paradigma dlya budushchego [Sustainable development: A paradigm for the future]. Mirovaya ekonomika $i$ mezhdunarodnye otnosheniya $=$ World Economy and International Relations, vol. 61, no. 3, pp. 107-113. (in Russ.)

Bobylev S., Zubarevich N., Solovyeva S. (2015). Vyzovy krizisa: kak izmeryat' ustoychivost' razvitiya? [Crisis challenges: How to measure sustainable development?]. Voprosy ekonomiki = The Issues of Economics, no. 1, pp. 147-160. (in Russ.)

Dementyeva A. G., Sokolova M. I. (2018). Kontseptsiya ustoychivogo razvitiya i sotsial'no-eticheskiy marketing [Sustainable development and social-ethical marketing]. Izvestiya Uralskogo gosudarstvennogo ekonomicheskogo universiteta = Journal of the Ural State University of Economics, 2018, vol. 19, no. 5, pp. 5-15. DOI: 10.29141/2073-10192018-19-5-1. (in Russ.)

Meadows D. H., Meadows D. L., Randers J., Behrens W. W. (1991). Predely rosta [The limits to growth]. Moscow: Moscow State University. 207 p. (in Russ.)

Moiseev N. N. (2013). Noosfera Vernadskogo i printsip koevolyutsii [Vernadsky's noosphere concept and the principle of co-evolution]. Vestnik ekologicheskogo obrazovaniya $v$ Rossii = Bulletin of Environmental Education in Russia, vol. 1, no. 67, pp. 4-7. (in Russ.)

Smagulova Zh. B., Mukhanova A. E., Musaeva G. I. (2015). Analiz mirovogo opyta perekhoda k zelenoy ekonomike: predposylki i napravleniya [Analysis of the world experience in the transition to a green economy: Prerequisites and directions]. Mezhdunarodnyy zhurnal prikladnykh i fundamentalnykh issledovaniy = International Journal of Applied and Fundamental Research, no. 1-1, pp. 92-96. (in Russ.)

Ananda J., Hampf B. (2015). Measuring environmentally sensitive productivity growth: An application to the urban water sector. Ecological Economics, vol. 116, pp. 211-219. DOI: https://doi.org/10.1016/j. ecolecon.2015.04.025.

Barbier E. B., Markandya A., Pearce D. W. (1990). Environmental sustainability and cost-benefit analysis. Environment and Planning, no. 22, pp. 1259-1266. DOI: 10.1068/a221259.

Brown J., Burnside W., Davidson A., DeLong J., Dunn W., Hamilton M., ... Zuo W. (2011). Energetic limits to economic growth. Bioscience, vol. 61, no. 1, pp. 19-26. DOI: 10.1525/bio.2011.61.1.7.

Caiado R., Dias R., Mattos L., Quelhas O., Filho W. (2017). Towards sustainable development through the perspective of eco-efficiency - A systematic literature review. Journal of Cleaner Production, vol. 165, pp. 890-904. DOI: https://doi.org/10.1016/j.jclepro.2017.07.166.

Daly H., Farley J. (2004). Ecological economics: Principles and applications. Washington, DC: Island Press. 484 p.

Dasgupta A., Dasgupta P. (2017). Socially embedded preferences, environmental externalities, and reproductive rights. Population and Development Review, no. 43 (3), pp. 405-441. DOI: 10.1111/ padr.12090.

Dasgupta P., Southerton D., Ulph A., Ulph, D. (2016). Consumer behaviour with environmental and social externalities: Implications for analysis and policy. Environmental and Resource Economics, vol. 65, no. 1, pp. 191-226. DOI: 10.1007/s10640-015-9911-3.

Egelston A. (2013). Sustainable development: A history. N.Y.; L.: Springer. 118 p.

Heikkurinen P., Young W., Morgan E. (2019). Business for sustainable change: Extending eco-efficiency and eco-sufficiency strategies to consumers. Journal of Cleaner Production, vol. 218, pp. 656-664. DOI: https://doi.org/10.1016/j.jclepro.2019.02.053.

Kanie N., Zondervan R., Betsill M. (2011). New visions of sustainable development governance. United Nation University. Available at: https://unu.edu/publications/articles/new-visions-of-sustainable-development-governance.html

Sachs J. D. (2015). The age of sustainable development. Columbia University Press. 544 p.

Shahraki A. A. (2019). Sustainable regional development through knowledge networks: Review of case studies. Frontiers of Architectural Research. DOI: https://doi.org/10.1016/j.foar.2019.04.004.

Wang Zh., Chen J., Zheng W., Deng X. (2018). Dynamics of land use efficiency with ecological intercorrelation in regional development. Landscape and Urban Planning, vol. 177, pp. 303-316. DOI: https:// doi.org/10.1016/j.landurbplan.2017.09.022. 
Weinstein M. P., Turner E. R., Ibáñez C. (2013). The global sustainability transition: It is more than changing light bulbs. Sustainability: Science, Practice, \& Policy, vol. 9, pp. 4-15.

Weinstein M. P., Litvin S. Y., Krebs J. M. (2014). Restoration ecology: Ecological fidelity, restoration metrics, and a systems perspective. Ecological Engineering, no. 65, pp. 71-87.

Yang L., Yang Y. (2019). Evaluation of eco-efficiency in China from 1978 to 2016: Based on a modified ecological footprint model. Science of the Total Environment, vol. 662, pp. 581-590. DOI: https://doi. org/10.1016/j.scitotenv.2019.01.225.

\section{Information about the author}

Daria S. Benz, Cand. Sc. (Econ.), Associate Prof. of Industries and Markets Dept., Chelyabinsk State University, 129 Bratyev Kashirinykh St., Chelyabinsk, 454001, Russia Phone: +7 (351) 799-71-46, e-mail: benz@csu.ru

() Бенц Д. С., 2019 
А. В. Мисюра АО «НПО автоматики», Уральский государственный экономический университет, г. Екатеринбург, Российская Федерация

\title{
Высокотехнологичное промышленное предприятие: нормативный и позитивный подходы к определению
}

\begin{abstract}
Аннотащия. Несмотря на широкое распространение в экономической науке и практике термина «высокотехнологичное промышленное предприятие», существует путаница в понимании и критериях отнесения компаний к таковым. Статья посвящена научному обзору подходов к трактовке и содержанию высокотехнологичного промышленного предприятия, на основе чего предложены принципы методического обоснования его технологического статуса. Методология исследования представлена совокупностью двух подходов: нормативного и позитивного. Кроме того, использованы положения теорий экономического роста, инноваций и технологических укладов. Методы исследования - критический анализ, синтез, систематизация институциональных данных. Автором выделены два вектора исследований технологического уровня предприятия. Нормативный подход направлен на приближение показателей предприятия к идеальным (нормативным) значениям, имеющимся в методиках международных организаций и государств. Главный недостаток такого подхода видится в присвоении предприятию статуса высокотехнологичного на основании принадлежности к конкретной отрасли и входных (ресурсных) параметров. Позитивный подход учитывает гетерогенность рынков и предполагает наличие у предприятия объективных различий в сравнении с другими в части результирующих показателей. С учетом специфики промышленных предприятий выделен ряд критериев, которые могут служить основой для адекватной оценки уровня их технологического развития. Выявлены объективные трудности такого мониторинга, связанные, в первую очередь, с проблемой измерения инновационности технологий. В связи с этим предложено использовать методику комплексного измерения статуса промышленного предприятия, который учитывает все элементы его бизнес-модели. Результаты исследования позволят устранить имеющиеся методические пробелы в оценке технологического уровня промышленного предприятия. Это даст возможность разработать стратегии развития предприятий и выбрать эффективные инструменты реализации промышленной политики.
\end{abstract}

Ключевые слова: промышленность; технология; высокотехнологичное предприятие; высокотехнологичная отрасль; инновация; нормативный подход; позитивный подход.

Для цитирования: Мисюра А. В. Высокотехнологичное промышленное предприятие: нормативный и позитивный подходы к определению // Journal of New Economy. 2019. T. 20, № 4. C. 88-107. DOI: 10.29141/2073-1019-2019-20-4-5

Дата поступления: 24 июня 2019 г.

\section{Введение}

Технологическое развитие как критерий экономического роста государств, рынков и 1 отдельных фирм исследуется достаточно давно [Шумпетер, 1982; Geroski, Machin, 1992; von Tunzelmann, 2000; Carlaw, Lipsey, 2003; Guarascio, Pianta, 2017]. В частности, 
Й. Шумпетер связывал экономическое развитие с появлением «новых комбинаций» в экономике: новых продуктов, способов производства, рынков сбыта, совершенствование в результате накопления знаний и инноваций. Ключевым элементом (показателем для оценки) инновационного процесса является НИОКР (R\&D). Инновационная активность в высокотехнологичных отраслях, как правило, выше, чем в среднем по экономике: компании интенсивно разрабатывают и внедряют новые технологии, обучают персонал, вводят отличающиеся от традиционных бизнес-процессы, активно используют цифровые инструменты и решения.

В России запущен режим технологического суверенитета и всеобщей технологизации. По мнению С. П. Земцова и А. В. Чернова [2019, с. 68], развитие высокотехнологичных компаний может рассматриваться как механизм структурной трансформации. Приоритеты развития страны ${ }^{1}$ направлены на увеличение доли высокотехнологичного сектора экономики. В Указе Президента России ${ }^{2}$ также отмечена необходимость ускоренного технологического развития в сфере несырьевого сектора экономики.

Национальный высокотехнологический статус в настоящее время можно определить как догоняющий, но находящийся в технологическом мейнстриме. По мнению О. С. Сухарева и Е. Н. Ворончихиной $[2019$, с. 28], «... рассуждения о том, что Россия может технологически отстать, относятся ко вчерашнему дню, поскольку наша страна уже сильно отстает, причем даже в тех направлениях, где сегодня лидирует».

Причины общего исчерпания технологичности экономики давно известны и широко обсуждаются. Среди них выделяют инвестиции в старые технологии, износ технической производственной базы, инфраструктурное (а не содержательное) направление цифровизации, упадочное состояние науки и образования и связанная с этим низкая отдача от инвестиций в человеческий капитал, разорванность технологических цепочек, структурный дисбаланс между секторами экономики.

Несмотря на ажиотаж вокруг высокотехнологичного сектора в деловых кругах, трактовки данного типа предприятий остаются весьма размытыми. Много несоответствий в представлениях о том, что есть высокотехнологичное предприятие в промышленности. В отличие от компаний, имеющих электронные бизнес-модели, в промышленном макросекторе все не так однозначно. Между тем определение достоверных критериев отнесения промышленных предприятий к высокотехнологичным является принципиальным. Это даст возможность снизить риски неэффективных собственных и государственных инвестиций. Кроме того, вектором технологизации, согласно программным документам РФ, является «сквозное развитие платформенных технологий», что предполагает работу промышленных предприятий в единой технологической системе. Иначе говоря, перспективность инвестиций в технологии должна измеряться не только с точки зрения экономического роста самого предприятия. Это является необходимым, но недостаточным. Технологии должны обеспечивать мультипликативный положительный эффект для всей экосистемы.

Таким образом, цель настоящего исследования заключается в уточнении критериев отнесения предприятий промышленности к высокотехнологичным.

Предлагаемую работу сложно назвать научным обзором. Помимо теоретических точек зрения, представляющих собой объективную сторону изучения вопроса, будут проанализированы нормативные подходы, основанные на законодательной базе РФ

1 Основные направления деятельности Правительства Российской Федерации на период до 2024 года (утв. Правительством РФ 29 сентября 2018 г.). URL: https://www.garant.ru

2 Указ Президента России от 7 мая 2018 г. № 204 «О национальных целях и стратегических задачах развития Российской Федерации на период до 2024 года». URL: https://www.garant.ru 
и других стран. Критический анализ этих подходов в совокупности с фиксацией и систематизацией критериев отнесения промышленного предприятия к высокотехнологичному составляет задачи данного исследования.

\section{Технологии и инновационность: природа и микрооснования}

Технология как движущая сила развития экономики и общества в целом была признана еще в теории стоимости [Маркс, 2011]. Факторы производства (производительные силы) и тип производственных отношений, по К. Марксу, составляют уникальную технологию.

Другие определения технологии трактуют ее как:

- формы поведения, следующего правилам [Ellul, 1964];

- использование средств для решения проблем, с которыми сталкиваются люди; машины и механизмы, используемые людьми для реализации их целей [Тамбовцев, 2019, с. 57];

- способ воздействия на различные объекты с целью добиться их изменения в необходимом направлении [Сухарев и Ворончихина, 2019, с. 85];

- преобразователь входов (ресурсов) в выходы (продукцию) [Тамбовцев, 2019, с. 58];

- приложение научного или иного знания к практическим задачам посредством упорядоченных систем, которые включают людей и организации, производственные навыки, живые существа и машины [Dusek, 2006, p. 35];

- совокупность создателей технологии, пользователей и принимающих решения лиц; материальных артефактов; институциональных характеристик организаций; формы давления внешней среды [Orlikowski, 1992, p. 409].

Таким образом, системное представление о технологии обусловлено рядом факторов. При этом для промышленных предприятий увязка технологического и институционального контекстов принципиально важна для достижения устойчивых конкурентных преимуществ [Орехова, 2018, с. 48]. Технологическое правило - это своеобразная «несущая конструкция» технологии, интегрирующая «входы» в нее (ресурсы) и определяющая последовательность применения к ним материальных артефактов, что обусловливает производство желаемого результата [Тамбовцев, 2019, с. 58].

Сочетание технического и институционального элементов определяет технологическую парадигму - модель решения отдельных технологических задач [Dosi, 1982, p. 152]. А. Пайне трактует технологическую парадигму как взаимодействие между ядром технологии (материальная составляющая), способом решения технических задач и представлениями практиков, ее реализующих [Рeine, 2008].

Распространение технологий описано в работе Е. М. Роджерса [Rogers, 1962]. Согласно его модели, диффузии инноваций, идея может воплотиться в технологию (продукт) только при условии, что она стала известна большому количеству (критической массе) потенциальных пользователей. Иной подход предлагает модель, в соответствии с которой базовым условием для решения о принятии технологии выступают ожидаемая эффективность, усилия внедрения, субъективные ожидания лица, принимающего решения и сложившаяся практика [Venkatesh et.al., 2003]. Этот же вывод делает Дж. Чайлд: «... преобладающая технология рассматривается как результат решений, принятых в отношении планов работ, ресурсов и оборудования на основе определенной оценки положения организации относительно внешней среды. Имеющаяся технологическая конфигурация может вызвать в краткосрочном периоде некоторую ригидность, ..., следовательно, может выступать в качестве препятствия для принятия новых планов» [Child, 1972, p. 6].

С другой стороны, Б. Артур отметил, что технологии, как правило, не изобретаются «с чистого листа», но являются комбинациями ранее существовавших [Arthur, 2009]. Таким образом, основным препятствием для принятия инноваций являются прежние 
технологические стандарты. При этом, в отличие от осознанного отказа от новых технологий (согласно модели [Venkatesh et.al., 2003]), отторжение инноваций возможно по причинам QWERTY-эффектов и иных институциональных ловушек, описанных в работах Д. Норта [1997]; Р. Дэвида [David 1985].

Кроме того, на используемые предприятием технологии и их укорененность оказывают воздействие функционирующие в экономике технологические уклады, представляющие собой совокупность сопряженных производств, имеющих единый технический уровень и развивающихся синхронно. Наиболее известными концепциями, объясняющими принципы выделения укладов, являются теория экономических циклов [Кондратьев, 1989], концепция «технико-экономической парадигмы» [Перес, 2011], собственно подход технологических укладов [Львов, 1990; Глазьев, 1993] и научно-технического развития [Шумпетер, 1982].

Таким образом, можно выделить три базовых уровня (и здесь мы согласны с А. В. Павловой [2010]; Е. В. Ивановой [2015]), которые поддерживают ту или иную технологию:

1) цивилизационный (цикличный) - определяется воздействием смены технологических укладов и модификации технологической культуры;

2) институциональный - формируется под воздействием целенаправленной государственной политики или иных установленных правил;

3) коммерческий (рыночный) - тиражирует технологию на рынке, если она экономически выгодна, зависит от состояния первых двух уровней.

Такая тройственность вызывает ряд трудностей в оценке реальной инновационности технологий, поскольку априорно сложно определить, является ли данная технология действительно новой, прорывной, приносящей долгосрочный эффект.

\section{Высокотехнологичное промышленное предприятие: нормативный и позитивный подходы к анализу}

Одним из основных методологических положений современной экономической науки считается разделение на позитивную («что есть») и нормативную («что должно быть») области исследования.

Первый из этих подходов основан на том, что оценки исследователя не должны влиять на выявленные им причинно-следственные связи. При этом внимание обращается на то, что дополнительную сложность создает неизбежное включение ценностных, нормативных элементов в область анализа. Наука не просто описывает изучаемые явления, а выдвигает рекомендации: как должна быть устроена и как должна действовать изучаемая система. Это возможно, если система по природе нормативная, т. е. способна воспринимать управляющие воздействия.

Второй подход подразумевает, что экономическая деятельность (по крайней мере, на уровне теоретического анализа) не находится под влиянием ценностных, нормативных элементов [Борисов, Мельник, 2006, с. 19]. Именно позитивный подход дает объективную оценку изучаемым явлениям и процессам, так как основан на исследовании конечных результатов.

Нормативный подход к применительно к анализу технологического развития промышленного предприятия предполагает установление идеальных обобщенных критериев его отнесения к тому или иному типу. На практике это означает, что выбор показателей для определения статуса предприятия основан на входных целевых параметрах, планах и системе долженствования.

Целевые установки задаются с помощью законов и других нормативно-правовых документов, методик международных организаций. Их главная схожая черта заключается 
в том, что выделяются высокотехнологичные отрасли, а не предприятия. В качестве триггеров экономического роста рассматриваются высокотехнологичные, наукоемкие, «передовые» ${ }^{1}$ и «технологически сложные» [Coad, Rao, 2008] отрасли. Наиболее авторитетными здесь признаны классификации Science \& Engineering Indicators Национального научного фонда США ${ }^{2}$ и ООН (в рамках Standard International Trade Classification - SITS) ${ }^{3}$. В Российской Федерации для определения уровня технологичности предприятия также используется упрощенный подход, связанный с выявлением его вида экономической деятельности (ОКВЭД) ${ }^{4}$. Все эти методики предполагают эксплуатацию (с разными, но не сильно отличающимися нормативными значениями) двух показателей для определения технологического статуса отрасли: доля НИОКР (на 1 работника) в структуре выручки, добавленной стоимости и т. п. и доля высокопрофессиональных работников (высокопроизводительных рабочих мест).

Тотальное использование представленных методик приводит к тому, что в целом серьезные исследования базируются на изначально ошибочной логике - все предприятия высокотехнологичной отрасли есть высокотехнологичные предприятия.

В работе А. А. Лаптева [2008], например, задача идентификации высокотехнологичных компаний на практике свелась к определению отраслей. С. В. Гаврилова [2014, с. 55] отмечает, что «... основной характеристикой высокотехнологичных компаний является потребление ими инноваций», т. е. в основе исследования лежит «входной» параметр оценки, отвечающий за затраты, а не за результаты. По мнению О. С. Сухарева и Е. Н. Ворончихиной $[2019$, с. 89], российский оборонный комплекс демонстрирует совершенные технологии, а гражданский сектор - отстающие. Масштабное исследование технологического развития проведено С. П. Земцовым и А. В. Черновым [2019], но и оно основывается на методике Росстата.

Причины популярности нормативного подхода в экономической среде понятны. Уровень технологий рассматривается как входной билет на первый ряд среди лидеров экономическом развития. Все крупнейшие экономические конгломераты, представленные отдельными странами или их группами, имеют официальные стратегии научно-технического развития. В России с 2014 г. действует прогноз научно-технологического развития на период до 2030 года ${ }^{5}$, в котором выделено семь перспективных направлений.

Представляется, что нормативный подход существенно искажает картину реальной технологичности отдельных промышленных предприятий. Это обусловлено целым рядом причин.

Во-первых, исследователи признают, что факт работы на конкретном рынке не означает априорную высокотехнологичность предприятия. Гетерогенность рынков и отраслей доказана еще в 1987 г. [Buzzel, Gale, 1987], эмпирически подтверждена в 1991 г. [Rumelt, 1991]. Выгоды от быстрорастущего рынка появляются одновременно у всех предприятий этой отрасли, что снижает их сравнительные конкурентные преимущества [Фляйшер, Бенсуссан, 2012, с. 255].

\footnotetext{
${ }^{1}$ URL: https://www.industryweek.com/workforce/americas-advanced-industries-new-trends-brookings-report

${ }^{2}$ URL: https://www.nsf.gov

${ }^{3}$ URL:http://www.gks.ru/metod/prilojenie4.htm

${ }^{4}$ Приказ Росстата от 15.12.2017 г. № 832 (ред. от 17.01.2019) «Об утверждении Методики расчета показателей “доля продукции высокотехнологичных и наукоемких отраслей в валовом внутреннем продукте” и “доля продукции высокотехнологичных и наукоемких отраслей в валовом региональном продукте субъекта Российской Федерации”». URL: http://www.consultant.ru

${ }^{5}$ Прогноз научно-технологического развития Российской Федерации на период до 2030 года (утв. Правительством РФ). URL: http://www.consultant.ru/document/cons_doc_LAW_157978/ (дата обращения: 17.06.2019).
} 
Во-вторых, методика Росстата выделяет высокотехнологичные, среднетехнологичные и наукоемкие виды деятельности. Уровень технологического развития определяется как отношение затрат на НИОКР к валовой добавленной стоимости. Критерием отнесения отрасли к числу наукоемких служит доля лиц с высоким уровнем профессионального образования в численности работников. Фактически предприятие при подсчете показателей может быть и высокотехнологичным, и наукоемким. Кроме того, пороговые значения этих показателей также весьма условны. Прототипом группировки Росстата послужила классификация ОЭСР, составленная на основе анализа отраслей промышленности развитых стран. Прямое соотнесение данных российской экономики и экономик развитых стран без учета параметров предприятия, институциональных и иных факторов его развития на практике показывает себя как неэффективное.

В-третьих, сомнения вызывают сами критерии отнесения отраслей к высокотехнологичным. В частности, может ли показатель наукоемкости служить адекватной основой для оценки уровня технологичности предприятий? Рынок труда в РФ за последние годы демонстрирует рост работников с высшим образованием ${ }^{1}$. Соответственно уровень наукоемкости может являться следствием структурных сдвигов на рынке труда, а не качества применяемых технологий.

Затраты на НИОКР как показатель технологичности предприятий тоже может быть весьма субъективным. Остается неясным, какие затраты в реальности определяют тот факт, что технология стала «высокой», инновационной. Кроме того, как отмечают О. С. Сухарев и Е. Н. Ворончихина [2019, с. 87], затраты на НИОКР означают поиск инноваций на уровне фундаментальной науки. В некоторых секторах экономики решения о том, как применить научные открытия в производстве, не возникают на протяжении довольно длительного времени.

В-четвертых, методика не разделяет макросекторы экономики. Однако специфика промышленного предприятия, в отличие, например, от IT-компании, весьма существенна. Микрооснования конкурентных преимуществ для промышленных предприятий принципиально отличаются от того, что требуется электронному бизнесу, торговле или банковскому сектору. Они определяют тип и направленность инноваций.

Вторым методом нормативной оценки, набирающим в последние годы популярность, становится патентный анализ (см., например [Bottazzi et al., 2002; Bloom, Reenen van, 2002; Гришина, 2008; Сиротин, 2016]). К высокотехнологичной продукции относятся разработки, обладающие изобретательским (или близким к нему) уровнем, защищенные патентами или специальными соглашениями (ноу-хау). Это дает возможность производителям получать дополнительную прибыль до тех пор, пока не появятся более новые технологии и уникальная продукция, имеющая абсолютные преимущества. Такая дополнительная прибыль называется интеллектуальной или технологической рентой [Гаврилова, 2014, с. 55]. Логика такого подхода довольно проста: чем больше патентов (лицензий, авторских прав и т. п.) у предприятия, тем более высокотехнологичным оно является. Как отмечалось выше, наличие даже запатентованной инновации не означает ее реального внедрения на рынке.

Помимо прочего, все нормативные виды анализа уровня технологичности промышленных предприятий имеют проблему сравнительной базы. Иначе говоря, если компания отличается от общей массы предприятий, причина может быть не только в высоком уровне развития этой компании, но и в низком уровне развития других компаний!

${ }^{1}$ Согласно переписи населения, доля работников с высшим образованием в 2010 г. по сравнению с 2002 г. выросла с 16 до $23 \%$. 
Общий уровень технологичности экономики, таким образом, может существенно сместить представления о статусе предприятия.

Позитивный подход к определению высокотехнологичного промыиленного предприятия более трудоемкий, но позволяет точнее измерить технологический уровень предприятия, детально изучить влияющие на него факторы и оценить результат (выходные параметры). Входные параметры, в том числе признанные базовыми показателями в нормативном анализе, могут рассматриваться только как сопутствующие условия и сигналы, оказывающие воздействие на инновационность предприятия. Среди них:

1) внутренние факторы: затраты на НИОКР [Nurmi, 2004; Macpherson, Holt, 2007; Sasidharan, Kathuria, 2011]; расходы на обучение работников [Баринова и др., 2015а]; объем нематериальных активов и интеллектуальной собственности [Coad, Rao, 2008; Daunfeldt et al., 2015]; наличие патентов [Bottazzi et al., 2002; Bloom, Reenen van, 2002]; размер предприятия [Dunne et al., 1989] и структура собственности [Абрамов и др., 2016];

2) внешние факторы: возможности заемного финансирования [Denicolai et al., 2015]; условия доступа к человеческому капиталу [Li, 2005] и рынкам в в целлом [Henderson, 2003; Li, 2005]; уровень технологического развития и специализации региона [Hoogstra, Dijk, 2004; Audretsch, Dohse, 2007; Баринова и др., 2015b; Бортник и др., 2015; Desai, Motoyama, 2015; Юсупова, Халимова, 2017]; государственная политика поддержки высоких технологий [O’Riain, 2004; Colombo et al., 2011; Zúñiga-Vicente et al., 2014; Симачев и др., 2014].

В России особое внимание уделяется исследованию особых институциональных условий как фактора развития технологий [Tkachenko et al., 2017; Абрамов и др., 2016]. На малых выборках проводится анализ других факторов развития технологических компаний [Баринова и др., 2015а; Медовников и др., 2016; Юсупова, Халимова, 2017].

Экономическая наука базируется на двух теориях, описывающих влияние технологии на деятельность предприятия. Теория операционной технологии (operations technology) производственных компаний, представленная в работах Дж. Вудверд [Woodward, 1965; 1970], связана с наличием ресурсов и с определением последовательности операций в производственном цикле предприятия. Вторая концепция, предложенная С. А. Перроу [Perrow, 1967; 1970], основана на оценке технологических характеристик используемых ресурсов (materials technology).

Технологическое обновление предполагает качественно иной способ производства. Это означает и принципиально другой способ ресурсообеспечения, построения бизнес-процессов и производства продукта. Систематизировать имеющиеся представления можно на основе концепции бизнес-модели и системной модели фирмы «ресурсы - бизнес-процессы - результаты», которые позволяют изучить специфику промышленных предприятий.

Pecypcb. Деятельность промышленного предприятия в традиционном представлении основана на трансформации материальных ресурсов в материальный продукт. Само производство основано на масштабном использовании основных средств, т. е. тоже физических активов. Иную бизнес-модель демонстрируют другие секторы экономики. Там в большей степени используются нематериальные активы, которые создают конкурентные преимущества, снижают окупаемость инвестиций и убывающую отдачу от производства.

Специфика предприятий промышленности блокирует переход к альтернативным, более эффективным бизнес-моделям. Тем не менее современные технологии даже в традиционных секторах экономики ориентированы на безотходность и безлюдность. 
Например, критерий безлюдности не означает тотального сокращения численности персонала. Скорее сократится число рабочих профессий в противовес специалистам и творческим профессиям.

Таким образом, изменение технологии влечет за собой преобразование:

- структуры требуемых ресурсов;

- относительной цены ресурсов;

- норм расхода ресурсов и отдачи от ресурсов;

- качества предлагаемых видов сырья, человеческого капитала и других ресурсов.

Мотивом к той или иной инновации является также стоимость ресурсов. При дешевой рабочей силе, например, технологии будут развиваться в направлении способа реализации товара, снижения материальных затрат, энергоэффективности и пр. Чем дороже услуги труда на рынке, тем больше предприятия будут стремиться к замещению труда капиталом.

Исследование ресурсов может быть познавательным для изучения динамических процессов на предприятии. Это важно еще и потому, что технологии в начале жизненного цикла не приносят прибыль. Однако, как было сказано ранее, в целом анализ затрат (ресурсов) уводит исследователя к принципам нормативного анализа, который не может дать адекватной оценки технологического уровня предприятия. Кроме того, сетевые процессы, экономика совместного потребления (аутсорсинг), финансовые инструменты (например, лизинг) дают возможность использовать ресурсы, не приобретаемые предприятием в собственность. Данный факт серьезно смещает получаемые оценки.

Бизнес-процессы. Из-за высокого порога минимального эффективного выпуска продукции традиционные промышленные предприятия - это чаще всего крупные предприятия, что снижает их стратегическую гибкость.

Тем не менее изменения в ресурсах могут вызывать трансформацию институтов, прежде всего тех, которые обусловливают установление прав собственности и их хозяйственный оборот [Норт, 2011]. Социально-экономические последствия технологических изменений не только бизнес-процессов самого предприятия, но и общей цифровизации экономики весьма масштабны (см., например: [Boserup, 1981; Uttley, 1984; Grübler, 2003]).

Оценка уровня технологичности бизнес-процессов на практике является довольно сложной. Именно поэтому используется простой в расчетах нормативный подход к анализу, утверждающий, что любые инвестиции считаются «инновационными». Фактически возникают вопросы: какой характер инноваций мы имеем, насколько они улучшают показатели эффективности предприятия, меняют ли качество бизнес-модели? Сама по себе такая оценка является весьма субъективной, поскольку, как отмечает О. С. Сухарев, Е. Н. Ворончихина $[2019$, с. 86], «... выделение новых и старых технологий во многом условно, причем наименование “старые” не означает, что они неэффективные и не могут использоваться».

Вопрос инноваций является лидирующим в понимании природы технологического прогресса. Их характер неоднороден. Так, Г. Менш [Mensh,1979] выделил базисные инновации, инновации усовершенствования и псевдоинновации. Только базисные инновации создают новые отрасли в экономике и возникают, как правило, группами.

Н. Кларк и К. Юма [Clark, Juma, 1987] определили два основных фактора развития научно-технической системы: институциональное давление и требования рынка. Это позволило им классифицировать три типа инноваций: инкрементальные (незначительные совершенствования), радикальные (новые процессы производства) и революционные (приводящие к сдвигу всей системы). Революционная технология характеризуется способностью генерировать крупномасштабное снижение издержек, вызывать значительное 
улучшение качественных характеристик технологического процесса и производимой продукции, воздействовать на межотраслевые связи [Теняков, 2016, с. 58]. Эта идеология согласуется с популярной в настоящее время концепцией «подрывных инноваций» [Кристенсен, Рейнор, Макдоналд, 2016]. В работе О. С. Сухарева [2014] выделяются ядро и периферия технологии. Обновление я приводит к научно-технологического процесса, обновление периферии - только к его совершенствованию.

Таким образом, проблема определения базовой технологии (ядра) является принципиально важной для правдивого (объективного) определения статуса промышленного предприятия. Но реальная оценка возможна только с применением кейс-стади, т. е. фактически для каждого отдельного предприятия требуется своя методика, учитывающая его развитие, технологические связи на рынке и многие другие факторы.

Считаем, что базовой является технология, которая:

- позволяет получать технологическую ренту предприятиям, находящимся в сети;

- заставляет предприятия ради этого создавать сети, мотивировать продолжительную работу в этой сети;

- определяет технологический стандарт для всей сети.

Последнее означает, что предприятие - держатель базовой технологии должно иметь более высокий технологический уклад, чем предприятия - аналоги (включая более широкую линейку конкурентов: прямых, потенциальных, товаров-заменителей). И это еще один способ определения технологического уровня предприятия - соотнесение его параметров и технологических укладов (стадий) развития экономической системы. Метод строится на предположении: если деятельность объекта исследования построена на технологиях, принципиально отличающихся от доминирующих технологий в экономике, то предприятие является высокотехнологичным.

Стоит отметить, что любое предприятие, в том числе промышленное, вовлечено в процессы сетевизации [Sukhodolov, Beryozkin, 2018]. Данный факт накладывает отпечаток на бизнес-модели таких предприятий, а следовательно, и на бизнес-процессы. Получается, что технологии должны обеспечивать эффект и для самого предприятия, и для всей технологической системы, в отношения с которой вовлечено промышленное предприятие. Именно этот критерий может быть основой определения технологического уровня предприятия.

Результаты. Главный парадокс, объясняющий несостоятельность нормативного подхода к анализу, заключается в том, что предприятие может использовать высокотехнологичные материалы, новейшее оборудование, иметь цифровую тень, но при этом выпускать продукцию, назвать которую высокотехнологичной нельзя. Причины этого могут быть как рыночно-институционального, так и внутриорганизационного характера.

Попытку измерить результирующие показатели технологизации осуществили авторы журнала РБК, составив рейтинг крупнейших технологических компаний России в 2015 и 2016 гг. ${ }^{1}$ Для рейтинга отбирались компании, которые производят технологии, и эта деятельность приносит им не менее 50 \% выручки. Технологический сектор в России очень маленький, около 100 предприятий. Совокупная выручка 50 первых участников рейтинга в несколько раз меньше выручки одной крупной сырьевой компании. Главный результат исследования: высокотехнологичные компании в России контролирует государство, и $2 / 3$ технологий - это государственный оборонный комплекс.

\footnotetext{
${ }^{1}$ URL: https://www.rbc.ru/ratings/business/04/06/2015/55674b3d9a7947eee1956ff0\#Kак\%20
} 
Еще один рейтинг оценки российских быстрорастущих технологических компаний «ТехУспех» ${ }^{1}$ реализуется в рамках программы Минэкономразвития России. В ходе анализа были разработаны основные критерии оценки уровня успешности и технологичности компаний, такие как среднегодовой темп роста выручки (от 20 до 10 \% в зависимости от размера); наличие новых или существенно улучшенных продуктов или услуг; доля выручки от продаж новой продукции за последние три года от 20 \% до 30 \%, затраты на НИОКР не менее 5 \% от выручки и технологические инновации не менее $10 \%$.

В работе Л. К. Шаминой, Т. Ю. Гораевой [2014] выделено восемь атрибутов высокотехнологичного предприятия: необходимость проведения НИОКР на протяжении всего жизненного цикла предприятия; значительная доля высококвалифицированных работников в общей численности занятых на предприятии; высокий удельный вес интеллектуальной собственности в составе активов; наличие прецизионных технологий, технологических инноваций и инновационной продукции; высокая значимость результатов НИОКР на каждой стадии производственного процесса; большие риски инновационных проектов; значительная роль неценовых конкурентных факторов в развитии предприятий.

При прочих равных условиях критерием качественной разности технологий может выступать уровень производительности труда [Капелюшников, 2014; Воскобойников, 2017]. Однако показатели производительности труда в немалой степени зависят от технологии производства и не могут быть универсальными по эффективности для различных отраслей [Бессонова, 2007, с. 13].

Обобщающим показателем оценки может служить совокупная производительность факторов [Easterly, Levine, 2001; Duval, de la Maisonneuve, 2010]. Вклад совокупной производительности в производство, согласно прогнозам, будет составлять $1,5 \%$ роста мирового ВВП [Йохансон и др., 2013, с. 22]. Логика расчета этого показателя проста: предприятие использует определенный набор факторов производства (труд и капитал) для выработки конечного продукта. Тогда рост используемых факторов производства или изменение комбинации их использования (т. е. технологии) приводят к увеличению выпуска конечного продукта [Орехова, Кислицын, 2019, с. 129] Измерение совокупной факторной производительности осуществляется с помощью производственных функций.

\section{Результаты исследования: предпосылки методического обоснования технологического статуса промышленного предприятия}

Исследование имеющихся подходов к определению уровня технологичности предприятия выявило ряд существенных проблем в его измерении, фрагментарность либо избыточность оценок (см. таблицу).

Методическое обеспечение оценки технологического статуса промышленного предприятия должно отвечать следующим принципам:

1) учет специфики деятельности промышленного предприятия;

2) определение собственного уровня развития предприятия исходя из динамической оценки его показателей;

3) комплексная оценка показателей деятельности предприятия по системе «ресурсы бизнес-процессы - результаты»;

4) сопоставление уровня технологичности предприятия с уровнем технологичности других предприятий на рынке, а также со среднерыночными показателями в российском и мировом масштабах.

\footnotetext{
${ }^{1}$ URL:http://www.ratingtechup.ru
} 
Методики исследования высокотехнологичных промышленных предприятий Methods for research of high-tech industrial enterprises

\begin{tabular}{|c|c|c|c|}
\hline Подходы & $\begin{array}{c}\text { Характеристика } \\
\text { подхода }\end{array}$ & Критерии оценки & $\begin{array}{c}\text { Недостатки подхода } \\
\text { (показателей оценки) }\end{array}$ \\
\hline Нормативный & $\begin{array}{l}\text { Выбор показателей } \\
\text { для определения } \\
\text { статуса предприятия } \\
\text { основан на входных } \\
\text { целевых параметрах, } \\
\text { планах и системе } \\
\text { долженствования }\end{array}$ & $\begin{array}{l}\text { Доля НИОКР в структуре } \\
\text { затрат предприятия. } \\
\text { Доля высококвалифициро- } \\
\text { ванных работников. } \\
\text { Патентный анализ }\end{array}$ & $\begin{array}{l}\text { Учет затрат, а не резуль- } \\
\text { татов. } \\
\text { Смещение оценок за счет } \\
\text { обобщенного анализа } \\
\text { в целом по отрасли. } \\
\text { Отсутствие учета специ- } \\
\text { фики промышленного } \\
\text { предприятия, институ- } \\
\text { циональных и рыночных } \\
\text { факторов }\end{array}$ \\
\hline Позитивный & $\begin{array}{l}\text { Установление при- } \\
\text { чинно-следственных } \\
\text { связей, влияющих } \\
\text { на конечный результат } \\
\text { деятельности пред- } \\
\text { приятия }\end{array}$ & $\begin{array}{l}\text { Доля выручки от новых } \\
\text { видов продукции и собст- } \\
\text { венных технологий. } \\
\text { Рост производительности } \\
\text { труда. } \\
\text { Сравнение технологическо- } \\
\text { го уровня предприятия } \\
\text { с доминирующим техноло- } \\
\text { гическим укладом. } \\
\text { Расчет совокупной произ- } \\
\text { водительности факторов }\end{array}$ & $\begin{array}{l}\text { Смещение оценок при } \\
\text { простом подсчете новой } \\
\text { продукции предприятия. } \\
\text { Отсутствие анализа типа } \\
\text { инноваций. } \\
\text { Трудности комплексной } \\
\text { оценки показателей } \\
\text { и учета всех факторов, } \\
\text { определяющих техноло- } \\
\text { гический статус }\end{array}$ \\
\hline
\end{tabular}

\section{Заключение}

Технологизация - это объективный процесс, который имеет очевидные положительные следствия: рост эффективности производства, доступности общественной инфраструктуры, уровня качества жизни населения. В условиях турбулентности технологизация способствует снижению рисков в результате стандартизации бизнес-процессов. В то же время развитие технологий связывают с высвобождением рабочих мест, монополизацией рынков, вымыванием малого бизнеса, дестабилизацией экономической системы из-за смены технологического порядка.

Несмотря на широкую практику выделения сектора хай-тек в структуре экономики, глубокое осмысление феномена такого рода предприятий показывает, что подходы к определению их технологического уровня весьма размыты и фрагментарны, носят нормативный, ненаучный характер. Конкуренция промышленных предприятий в основном осуществляется за счет техники и технологий, поэтому различия в технологиях определяют отличия эффективности предприятий и как следствие национальных отраслей (в большинстве исследований нормативного подхода все представляется наоборот).

Процесс технологизации может происходить под влиянием только рыночных механизмов, либо быть управляемым посредством целенаправленной государственной политики. Во втором случае значение технологизации усиливается, она превращается в ресурс, формируя конкурентное преимущество для той экономической системы, в которой созданы условия, максимально благоприятствующие появлению и быстрому тиражированию новых технологий.

При формировании промышленной политики целесообразно направлять усилия на отдельные бизнес-единицы (предприятия, сети или платформы), а не секторы или отрасли. Продолжающиеся споры относительно поддержки предприятий для увеличения 
доли высокотехнологичных и наукоемких отраслей в валовом внутреннем продукте страны свидетельствуют о том, что в случае значительной дифференциации экономики по технологическим укладам (как в российской экономике) довольно сложно установить приоритеты финансирования.

Существует логический разрыв в методиках, объясняющих взаимосвязь понятий «высокотехнологичная отрасль - конкурентоспособное предприятие - экономический рост». Считаем, что методика, основанная на анализе отдельных предприятий с учетом их специфики и условий хозяйствования, позволит увидеть полную и неискаженную картину для принятия решений в рамках промышленной политики. Именно эту задачу ставит перед собой автор в дальнейших исследованиях.

\section{Источники}

Абрамов А. Е., Радыгин А. Д., Чернова М. И. (2016). Компании с государственным участием на российском рынке: структура собственности и роль в экономике // Вопросы экономики. № 12. C. 61-87.

Баринова В. А., Бортник И. М., Земцов С. П., Сорокина А. В. (2015а). Анализ факторов конкурентоспособности отечественных высокотехнологичных компаний // Инновации. № 3 (197). C. 25-31.

Баринова В. А., Еремкин В. А., Земцов С. П. (20156). Факторы развития инновационных компаний на ранних стадиях // Государственное управление. Электронный вестник. № 49. C. $27-51$.

Бессонова Е. В. (2007). Оценка эффективности производства российских промышленных предприятий // Прикладная эконометрика. № 2 (6). С. 13-35.

Бортник И. М., Земцов С. П., Иванова О. В., Куценко Е. С., Сорокина А. В., Павлов П. Н. (2015). Становление инновационных кластеров в России: итоги первых лет поддержки // Инновации. № 7. С. 26-36.

Борисов Г. В., Мельник Д. В. (2006). Позитивный и нормативный подходы в экономической науке // Вестник СПбГУ. Сер. 5. Вып. 2. С. 17-28.

Гаврилова С. В. (2014). Концептуальные основы определения высокотехнологичного сектора экономики и функционирования высокотехнологичных компаний» // Экономика, статистика и информатика, № 2. С. 53-57.

Глазьев С. Ю. (1993). Теория долгосрочного технико-экономического развития. М.: Владар. $310 \mathrm{c}$.

Гришина С. В. (2008). Патентный анализ как инструмент стратегической диагностики // Научно-технические ведомости СПбГУ. Экономические науки. № 1. С. 113-116.

Земцов С. П., Чернов А. В. (2019). Какие высокотехнологичные компании в России растут быстрее и почему // Журнал новой экономической ассоциации. № 1 (41). С. 68-99.

Иванова Е. В. (2015). Закономерности технологизации современной экономической системы // Теоретическая экономика. № 5. С. 60-65.

Йоханссон А., Гийемет И., Муртин Ф. (2013). Сценарии долгосрочного глобального роста до 2060 г. // Вестник международных организаций. № 4. С. 7-39.

Капелюшников Р. И. (2014). Производительность и оплата труда: немного простой арифметики: препринт WP3/2014/01 / Нац. исслед. ун-т «Высшая школа экономики». М.: Изд. дом ВШЭ. Cер.: WP3 «Проблемы рынка труда».

Кондратьев Н. Д. (1989). Большие циклы экономической конъюнктуры: доклад // Проблемы экономической динамики. М.: Экономика. С. 172-226. 523 с.

Кристенсен К., Рейнор М., Макдоналд Р. (29 февраля 2016). Подрывные инновации: двадцать лет спустя // Harvard Business Review. URL: https://hbr-russia.ru/innovatsii/upravlenie-innovatsiyami/ a17234

Лаптев А. А. (2008). Понятие «высокотехнологичной компании» в современной микроэкономической теории // Качество. Инновации. Образование. №1. 
Львов Д. С. (1990). Эффективность управления техническим развитием. М.: Экономика.

Маркс К. (1997). Капитал: критика политической экономии. Т. 3. М.: Эксмо.

Медовников Д. С., Оганесян Т. К., Розмирович С. Д. (2016). Кандидаты в чемпионы: средние быстрорастущие компании и программы их поддержки // Вопросы экономики. № 9. С. 50-66.

Норт Д. (1997). Институты, институциональные изменения и функционирование экономики. М: Фонд экономической книги «Начала».

Орехова С. В. (2018). Формирование методологии устойчивого развития металлургического предприятия на основе ресурсно-институционального подхода: дис. ... д-ра экон. Наук. Екатеринбург. 387 с.

Орехова С. В., Кислицын Е. В. (2019). Совокупная производительность факторов в промышленности России: малые vs крупные предприятия // Journal of New Economy. T. 20, № 2. C. 127-144. DOI: $10.29141 / 2073-1019-2019-20-2-8$

Павлова А. В. (2010). Методологические основы технологизации производства и экономики // Вестник Самарского государственного университета. № 5. С. 39-45.

Перес К. (2011). Технологические революции и финансовый капитал. Динамика пузырей и периодов процветания. М.: Дело АНХ.

Симачев Ю. В., Кузык М. Г., Фейгина В. В. (2014). Государственная поддержка инноваций в России: что можно сказать о воздействии на компании налоговых и финансовых механизмов? // Российский журнал менеджмента. № 12 (1). С. 7-38.

Сиротин Д. В. (2016). Разработка методологического подхода к измерению технологического облика базовой отрасли региона // Журнал экономической теории. № 2. С. 173-177.

Сухарев О. С. (2014). Экономический рост, институты и технологии. М.: Финансы и статистика.

Сухарев О. С., Ворончихина Е. Н. (2019). Стратегия индустриализации экономики: Исследование структуры экономического роста и технологического развития. М.: ЛЕНАНД.

Тамбовцев В. Л. (2019). Взаимодействие «институты-технологии» и экономический рост // Journal of New Economy. T. 20. № 2. C. 55-70. DOI: 10.29141/2073-1019-2019-20-2-3.

Теняков, И. М. (2016). Современный экономический рост: источники, факторы, качество: монография. М.: Проспект.

Фляйшер К., Бенсуссан Б. (2012). Стратегический и конкурентный анализ. Методы и средства конкурентного анализа в бизнесе. М.: Бином. Лаборатория знаний.

Шамина Л. К., Гораева Т. Ю. (2014). Атрибутивные признаки высокотехнологичных компаний // Научный журнал НИУ ИТМО. Сер.: «Экономика и экологический менеджмент», № 2. URL: http://economics.ihbt.ifmo.ru/ru/article/11150/atributivnye_priznaki_vysokotehnologichnyh_ predpriyatiy.htm

Шумпетер Й. (1982). Теория экономического развития. М.: Прогресс.

Юсупова А. Т., Халимова С. Р. (2017). Характеристики, особенности развития, региональные и отраслевые детерминанты высокотехнологичного бизнеса в России // Вопросы экономики. № 12. C. $142-154$.

Arthur W. B. (2009). The nature of technology: What it is and how it evolves. N. Y.: Free Press. 246 p.

Audretsch D., Dohse D. (2007). Location: A neglected determinant of firm growth. Review of World Economics, vol. 143, issue 1, pp. 79-107.

Bloom N., Van Reenen J. (2002). Patents, real options and firm performance. The Economic Journal, vol. 112, issue 478, pp. 97-116.

Boserup E. (1981). Population and technological change. Chicago: University of Chicago Press. 255 p. Bottazzi G., Cefis E., Dosi G. (2002). Corporate growth and industrial structures: some evidence from the Italian manufacturing industry. Industrial and Corporate Change, vol. 11, issue 4, pp. 705-723.

Buzzel R. D., Gale B. T. (1987). The PIMS principles: Linking strategy to performance. N. Y.: Free Press. Carlaw K. I., Lipsey R. G. (2003). Productivity, technology and economic growth: What is the relationship? Journal of Economic Surveys, vol. 17, issue 3, pp. 457-495.

Child J. (1972). Organizational structure, environment and performance: the role of strategic choice. Sociology, no. 6. pp. 1-22.

Clark N., Juma K. (1987). Long-term economics: An evolutionary approach to economic growth. L., N.Y. 
Coad A., Rao R. (2008). Innovation and firm growth in high-tech sectors: A quantile regression approach. Research Policy, vol. 37 (4), pp. 633-648.

Colombo M., Grilli L., Murtinu S. (2011). R\&D subsidies and the performance of high-tech start-ups. Economics Letters, vol. 112, issue 1, pp. 97-99.

Daunfeldt S., Elert N., Johansson D. Overrepresented in high-tech industries? Industrial and Corporate Change, vol. 25, issue 1, pp. 1-21.

David P. (1985). Clio and Economics of QWERTY. American Economic Review, vol. 75, no. 2.

Denicolai S., Cotta Ramusino E., Sotti F. (2015). The impact of intangibles on firm growth. Technology Analysis \& Strategic Management, vol. 27, issue 2, pp. 219-236.

Desai S., Motoyama Y. (2015). The regional environment: Indianapolis-insights from high-growth companies. Kansas City: Kaufmann Foundation. 28 p.

Dosi G. (1982). Technological paradigms and technological trajectories: A suggested interpretation of the determinants and directions of technical change. Research Policy, vol. 11, issue 3, pp. 147-162.

Dunne T., Roberts M. J., Samuelson L. (1989). The growth and failure of US manufacturing plants. The Quarterly Journal of Economics, vol. 104, issue 4, pp. 671-698.

Dusek V. (2006). Philosophy of technology: An introduction. Malden: Blackwell Publishing. 256 p.

Duval R., de la Maisonneuve C. (2010). Long-run growth scenarios for the world economy. Journal of Policy Modeling, vol. 32, no. 1, pp. 64-80.

Easterly W., Levine R. (2001). It's not factor accumulation: stylized facts and growth models. World Bank Economic Review, vol. 15, no. 2, pp. 177-219.

Ellul J. (1964). The technological society. N. Y.: Vintage Books. 449 p.

Geroski P., Machin S. (1992). Do innovating firms outperform non-innovators? Business Strategy Review, vol. 3, no. 2, pp. 79-90.

Grübler A. (2003). Technology and global change. Cambridge: Cambridge University Press. 464 p.

Guarascio D. \& Pianta M. (2017). The gains from technology: new products, exports and profits. Economics of Innovation and New Technology, vol. 26, isssue 8, pp. 779-804. DOI: http://dx.doi.org/10.1 080/10438599.2016.1257446

Henderson V. (2003). Marshall's scale economies. Journal of Urban Economics, vol. 53, no. 1, pp. 1-28. Hoogstra G. J., Dijk J., van (2004). Explaining firm employment growth: Does location matter? Small Business Economics, vol. 22, issue 3-4, pp. 179-192.

Li S. (2005). High tech spatial concentration: Human capital, agglomeration economies, location theories and creative cities. Louisville: University of Louisville. DOI: https://doi.org/10.18297/etd/824

Macpherson A., Holt R. (2007). Knowledge, learning and small firm growth: A systematic review of the evidence. Research Policy, vol. 36, no. 2, pp. 172-192.

Mensh G. (1979). Stalemate in technology: Innovations overcome the depression. Cambridge.

Nurmi S. (2004). Plant size, age and growth in Finnish manufacturing. Finnish Economic Papers, vol. 17, no. 1, pp. 3-17.

O'Riain S. (2004). The politics of high tech growth: Developmental network states in the global economy. Cambridge: Cambridge University Press.

Orlikowski W. (1992). The duality of technology: Rethinking the concept of technology in organizations. Organization Science, vol. 3, issue 3, pp. 398-427.

Peine A. (2008). Technological paradigms and complex technical systems- the case of smart homes. Research Policy, vol. 37, issue 3, pp. 508-529.

Perrow C. A. (1970). Organizational analysis: A sociological view. L.: Tavistock. 192 p.

Perrow C. A. (1967). Framework for the comparative analysis of organizations. American Sociological Review, no. 32, pp. 194-208.

Rogers E. M. (1962). Diffusion of innovations. 1st ed. N. Y.: Free Press.

Rumelt R. P. (1991). How much does industry matter? Strategic Management Journal, vol. 12, no. 3 , pp. 167-185.

Sasidharan S., Kathuria V. (2011). Foreign direct investment and R\&D: Substitutes or complements - a case of Indian manufacturing after 1991 reforms. World Development, vol. 39, no. 7, pp. 1226-1239.

Sukhodolov A. P., Beryozkin Yu. M. (2018). From the institutional to the platform economy // Управленец. Т. 9, № 3. С. 8-13. DOI: 10.29141/2218-5003-2018-9-3-2 
Tkachenko A., Yakovlev A., Kuznetsova A. (2017). 'Sweet deals': State-owned enterprises, corruption and repeated contracts in public procurement. Economic Systems, vol. 41, no. 1, pp. 52-67.

Tunzelmann G. N., von (2000). Technology generation, technology use and economic growth. European Review of Economic History, vol. 4, issue 2, pp. 121-146.

Uttley S. (1984). Reformulating the development theory of welfare. Journal of Social Policy, vol. 13, issue 4, pp. 447-465.

Venkatesh V., Morris M. G., Davis G. B., Davis F. D. (2003). User acceptance of information technology: Toward a unified view. MIS Quarterly, vol. 27, no. 3, pp. 425-478.

Voskoboynikov I. V. (2017). Sources of long run growth of the Russian economy before and after the global financial crisis. Russian Journal of Economics, no. 3 (4), pp. 348-365. DOI: https://doi.org/10.1016/j. ruje.2017.12.003

Woodward J. (1965). Industrial organization: Theory and practice. L.: Oxford University Press. 281 p.

Woodward J. (1970). Industrial organization: Behavior and control. L.: Oxford University Press. 262 p.

Zúñiga-Vicente J. Á., Alonso-Borrego C., Forcadell F. J., Galán J. I. (2014). Assessing the effect of public subsidies on firm R\&D investment: A survey. Journal of Economic Surveys, vol. 28, issue 1, pp. 36-67. DOI: https://doi.org/10.1111/j.1467-6419.2012.00738.x

\section{Информация об авторе}

Мисюра Андрей Васильевич, генеральный директор АО «НПО автоматики», 620075, РФ, г. Екатеринбург, ул. Мамина-Сибиряка, 145; аспирант кафедры экономики предприятий Уральского государственного экономического университета, 620144, РФ, г. Екатеринбург, ул. 8 Марта/Народной Воли, 62/45

Контактный телефон: +7 (343) 214-80-40, e-mail: asp_avm@mail.ru

Andrey V. Misyura Scientific and Production Association of Automatics named after academician

N.A. Semikhatov, Ural State University of Economics, Ekaterinburg, Russia

\section{High-tech industrial company: A normative and a positive approach to the definition}

Abstract. Despite the term "high-tech industrial company" is widely spread in economic science and practical activities, there is some confusion about its understanding and criteria for classifying companies as such. The paper reviews approaches to the treatment and essence of high-tech industrial companies and based on that puts forward the principles for methodological justification of their technological status. The research methodology rests on the combination of two approaches: a normative and a positive analysis. Additionally, the research employs the theory of economic growth, innovation and technological waves theory. The methods of research include critical analysis, synthesis, and institutional data systematisation. The author identifies two lines in the research of the company technological level. The normative approach aims to making company indicators closer to the ideal (normative) values present in the international organisations and foreign countries' guidelines. The major setback of such approach seems to be that the high-tech status is assigned to the company on two grounds: belonging to a particular industry and input (resource) parameters. The positive approach takes into account the heterogeneity 
of markets and implies that a company differs objectively from others in terms of the performance indicators. Given the specifics of industrial companies, the author identifies a number of criteria, which can form a basis for an adequate assessment of the level of their technological development. The paper reveals the objective difficulties of such monitoring connected primarily with the problem of measuring the novelty of technologies. For this, the author suggests using a method of complex measurement of industrial company status, which allows for all the elements of the business model. The research findings fill the methodological gaps in the evaluation of the industrial company technological level, which opens up a possibility to devise company development strategies and select efficient tools for implementing the industrial policy.

Keywords: industry; technology; high-tech company; high-tech market; innovation; normative approach; positive approach.

For citation: Misyura A. V. Vysokotekhnologichnoe promyshlennoe predpriyatie: normativnyy i pozitivnyy podkhody k opredeleniyu [High-tech industrial company: A normative and a positive approach to the definition]. Journal of New Economy, 2019, vol. 20, no. 4, pp. 88-107. DOI: 10.29141/2073-1019-2019-20-4-5

Received June 24, 2019.

\section{References}

Abramov A. E., Radygin A. D., Chernova M. I. (2016). Kompanii s gosudarstvennym uchastiyem na rossiyskom rynke: struktura sobstvennosti i rol'v ekonomike [Companies with the state participation in the Russian market: ownership structure and the role in the economy]. Voprosy ekonomiki $=$ The Issues of Economics, no. 12, pp. 61-87. (in Russ.)

Barinova V. A., Bortnik I. M., Zemtsov S. P., Sorokina A.V. (2015a). Analiz faktorov konkurentosposobnosti otechestvennykh vysokotekhnologichnykh kompaniy [Analysis of the competitiveness factors of domestic high-tech companies]. Innovatsii = Innovations, no. 3 (197), pp. 25-31. (in Russ.)

Barinova V. A., Eremkin V. A., Zemtsov S. P. (2015b). Faktory razvitiya innovatsionnykh kompaniy na rannikh stadiyakh [Factors of development of innovative companies in the early stages]. Gosudarstvennoye upravleniye. Elektronnyy vestnik = Public Administration. E-Journal, no. 49, pp. 27-51. (in Russ.)

Bessonova E. V. (2007). Otsenka effektivnosti proizvodstva rossiyskikh promyshlennykh predpriyatiy [Evaluation of the efficiency of production in Russian industrial enterprises]. Prikladnaya ekonometrika $=$ Applied Econometrics, no. 2(6), pp. 13-35. (in Russ.)

Bortnik I. M., Zemtsov S. P., Ivanova O. V., Kutsenko E. S., Sorokina A. V., Pavlov P. N. (2015). Stanovleniye innovatsionnykh klasterov $\mathrm{v}$ Rossii: itogi pervykh let podderzhki [The formation of innovation clusters in Russia: the results of the first years of support]. Innovatsii = Innovations, no. 7, pp. 26-36. (in Russ.)

Borisov G. V., Melnik D. V. (2006). Pozitivnyy i normativnyy podkhody v ekonomicheskoy nauke [Positive and normative approaches in economic science]. Vestnik SPbGU. Seriya 5=Bulletin of Saint Petersburg State University. Series 5, vol. 2, p.17-28. (in Russ.)

Gavrilova S. V. (2014). Kontseptual'nyye osnovy opredeleniya vysokotekhnologichnogo sektora ekonomiki i funktsionirovaniya vysokotekhnologichnykh kompaniy [Conceptual framework for determining the high-tech sector of the economy and the operation of high-tech companies]. Ekonomika, statistika $i$ informatika = Economics, Statistics and Information Science, no. 2, pp. 53-57. (in Russ.)

Glazyev S. Yu. (1993). Teoriya dolgosrochnogo tekhniko-ekonomicheskogo razvitiya [Theory of longterm technical and economic development]. Moscow: Vladar Publ. 310 p. (in Russ.)

Grishina S. V. (2008). Patentnyy analiz kak instrument strategicheskoy diagnostiki [Patent analysis as a tool for strategic diagnostics]. Nauchno-tekhnicheskie vedomosti SPbGU. Ekonomicheskie nauki = Scientific and Technical Statements of Saint Petersburg State University. Economic Sciences, no. 1, pp. 113-116. (in Russ.)

Zemtsov S. P., Chernov A.V. (2019). Kakiye vysokotekhnologichnyye kompanii v Rossii rastut by- 
streye i pochemu [What high-tech companies in Russia are growing faster and why]. Zhurnal novoy ekonomicheskoy assotsiatsii = Journal of New Economic Association, no. 1 (41), pp. 68-99. (in Russ.)

Ivanova E. V. (2015). Zakonomernosti tekhnologizatsii sovremennoy ekonomicheskoy sistemy [Patterns of technologization of the modern economic system]. Teoreticheskaya ekonomika = Theoretical Economics, no. 5, pp. 60-65. (in Russ.)

Johansson A., Guillemet I., Murtin F. (2013). Stsenarii dolgosrochnogo global'nogo rosta do $2060 \mathrm{~g}$ [Scenarios of long-term global growth until 2060]. Vestnik mezhdunarodnykh organizatsiy $=$ Bulletin of International Organizations, no. 4, pp. 7-39. (in Russ.)

Kapelyushnikov R. I. (2014). Proizvoditel'nost' i oplata truda: nemnogo prostoy arifmetiki. Preprint \# WP3/2014/01 [Productivity and wages: A little of simple arithmetic. Preprint \# WP3/2014/01]. Moscow: Higher School of Economics. (in Russ.)

Kondratiev N. D. (1989). Large cycles of economic conditions: A report. In: Kondratiev N. D. Problemy ekonomicheskoy dinamiki [Problems of economic dynamics]. Moscow: Economika Publ., pp. 172226. (in Russ.)

Christensen K., Raynor M., MacDonald R. (February 29, 2016). Podryvnyye innovatsii: dvadtsat' let spustya [Disruptive innovations: Twenty years later]. Harvard Business Review $=$ Harvard Business Review. Available at: https://hbr-russia.ru/innovatsii/upravlenie-innovatsiyami/a17234. (in Russ.)

Laptev A. A. (2008). Ponyatiye "vysokotekhnologichnoy kompanii" v so-vremennoy mikroekonomicheskoy teorii [The concept of "high-tech company" in the contemporary microeconomics]. Kachestvo. Innovatsii. Obrazovaniye = Quality. Innovation. Education, no. 1. (in Russ.)

Lvov D. S. (1990). Effektivnost' upravleniya tekhnicheskim razvitiyem [The effectiveness of technical development management]. Moscow: Economika Publ. (in Russ.)

Marx K. Kapital: kritika politicheskoy ekonomii. T. 3. [Capital: critique of political economy. Vol. 3]. Moscow: Eksmo Publ. (in Russ.)

Medovnikov D. S., Oganesyan T. K., Rozmirovich S. D. (2016). Kandidaty v chempiony: sredniye bystrorastushchiye kompanii i programmy ikh podderzhki [Candidates for champions: medium-sized fast-growing companies and programs for their support]. Voprosy ekonomiki = The Issues of Economics, no. 9, pp. 50-66. (in Russ.)

North D. (1997). Instituty, institutsional'nyye izmeneniya i funktsionirovaniye ekonomiki [Institutions, institutional change and economic performance]. Moscow: Fond ekonomicheskoy knigi "Nachala" Publ., 1997. (in Russ.)

Orekhova S.V. (2018). Formirovanie metodologii ustoychivogo razvitiya metallurgicheskogo predpriyatiya na osnove resursno-institutsional'nogo podkhoda. Diss. dokt. ekon. nauk [The formation of a sustainable development methodology for a metallurgical enterprise based on a resource-institutional approach. Dr. econ. sci. diss.]. Ekaterinburg, Russia, 2018. 387 p. (in Russ.)

Orekhova S. V., Kislitsyn E. V. (2019). Sovokupnaya proizvoditel'nost' faktorov v promyshlennosti Rossii: malye vs krupnye predpriyatiya [Total factor productivity in the Russian industry: Small vs large enterprises]. Journal of New Economy, vol. 20, no. 2, pp. 127-144. DOI: 10.29141/2073-1019-2019-20-2-8.

Pavlova A.V. (2010). Metodologicheskiye osnovy tekhnologizatsii proizvodstva i ekonomiki [Methodological bases of technologization of production and economy]. Vestnik Samarskogo gosudarstvennogo universiteta $=$ Bulletin of the Samara State University, no. 5, pp. 39-45. (in Russ.)

Perez C. (2011). Tekhnologicheskiye revolyutsii i finansovyy kapital. Dinamika puzyrey i periodov protsvetaniya [Technological revolution and financial capital. The dynamics of bubbles and golden ages] Moscow: Delo ANH Publ. (in Russ.)

Simachev U. V., Kuzyk M. G., Feigina V. V. (2014). Gosudarstvennaya podderzhka innovatsiy v Rossii: chto mozhno skazat' o vozdeystvii na kompanii nalogovykh i finansovykh mekhanizmov? [Government support for innovation in Russia: What can be said about the tax and financial mechanisms' impact on companies?]. Rossiyskiy zhurnal menedzhmenta = Russian Management Journal, no. 12 (1), pp. 7-38. (in Russ.)

Sirotin D. V. (2016). Razrabotka metodologicheskogo podkhoda k izmereniyu tekhnologicheskogo oblika bazovoy otrasli regiona [Development of a methodological approach to the measurement of the technological appearance of the basic industry of the region]. Zhurnal ekonomicheskoy teorii $=$ Russian Journal of Economic Theory, no. 2, pp. 173-177. (in Russ.) 
Sukharev O. S. (2014). Ekonomicheskiy rost, instituty i tekhnologii [Economic growth, institutions and technologies]. Moscow: Finansy i statistika Publ. (in Russ.)

Sukharev O. S., Voronchikhina Ye. N. (2019). Strategiya industrializatsii ekonomiki: Issledovaniye struktury ekonomicheskogo rosta i tekhnologicheskogo razvitiya [Strategy of industrialization of the economy: A study of the structure of economic growth and technological development]. Moscow: LENAND Publ. (in Russ.)

Tambovtsev V. L. (2019). Vzaimodeystvie "instituty-tekhnologii" i ekonomicheskiy rost [Institutionstechnologies interaction and economic growth]. Journal of New Economy, 2019, vol. 20, no. 2, pp. 55-70. DOI: 10.29141/2073-1019-2019-20-2-3 (in Russ.)

Tenyakov I. M. (2016). Sovremennyy ekonomicheskiy rost: istochniki, faktory, kachestvo [Modern economic growth: Sources, factors, quality]. Moscow: Prospekt Publ. (in Russ.)

Fleischer K., Bensussan B. (2012). Strategicheskiy i konkurentnyy analiz. Metody i sredstva konkurentnogo analiza $v$ biznese [Strategic and competitive analysis. Methods and means of competitive analysis in business]. Moscow: Binom. Laboratoriya znaniy Publ. (in Russ.)

Shamina L. K., Goraeva T. U. (2014). Atributivnyye priznaki vysokotekhnologichnykh kompaniy [The attributes of high-tech companies]. Nauchnyy zhurnal NIU ITMO. Seriya "Ekonomika i ekologicheskiy menedzhment" = Scientific journal NRU ITMO. Series "Economics and Environmental Management, no. 2. Available at: http://economics.ihbt.ifmo.ru/ru/article/11150/atributivnye_priznaki_vysokotehnologichnyh_predpriyatiy.htm (in Russ.)

Schumpeter J. (1982). Teoriya ekonomicheskogo razvitiya [The theory of economic development]. Moscow: Progress Publ. (in Russ.)

Yusupova A. T., Halimova S. R. (2017). Kharakteristiki, osobennosti razvitiya, regional'nyye i otraslevyye determinanty vysokotekhnologichnogo biznesa v Rossii [Characteristics, specifics of development, regional and industry determinants of high-tech business in Russia]. Voprosy ekonomiki $=$ The Issues of Economics, no. 12, pp. 142-154. (in Russ.)

Arthur W. B. (2009). The nature of technology: What it is and how it evolves. N. Y.: Free Press. 246 p.

Audretsch D., Dohse D. (2007). Location: A neglected determinant of firm growth. Review of World Economics, vol. 143, issue 1, pp. 79-107.

Bloom N., Van Reenen J. (2002). Patents, real options and firm performance. The Economic Journal, vol. 112, issue 478, pp. 97-116.

Boserup E. (1981). Population and technological change. Chicago: University of Chicago Press. 255 p.

Bottazzi G., Cefis E., Dosi G. (2002). Corporate growth and industrial structures: some evidence from the Italian manufacturing industry. Industrial and Corporate Change, vol. 11, issue 4, pp. 705-723.

Buzzel R. D., Gale B. T. (1987). The PIMS principles: Linking strategy to performance. N. Y.: Free Press.

Carlaw K. I., Lipsey R. G. (2003). Productivity, technology and economic growth: What is the relationship? Journal of Economic Surveys, vol. 17, issue 3, pp. 457-495.

Child J. (1972). Organizational structure, environment and performance: the role of strategic choice. Sociology, no. 6. pp. 1-22.

Clark N., Juma K. (1987). Long-term economics: An evolutionary approach to economic growth. L., N.Y.

Coad A., Rao R. (2008). Innovation and firm growth in high-tech sectors: A quantile regression approach. Research Policy, vol. 37 (4), pp. 633-648.

Colombo M., Grilli L., Murtinu S. (2011). R\&D subsidies and the performance of high-tech start-ups. Economics Letters, vol. 112, issue 1, pp. 97-99.

Daunfeldt S., Elert N., Johansson D. Overrepresented in high-tech industries? Industrial and Corporate Change, vol. 25, issue 1, pp.1-21.

David P. (1985). Clio and Economics of QWERTY. American Economic Review, vol. 75, no. 2.

Denicolai S., Cotta Ramusino E., Sotti F. (2015). The impact of intangibles on firm growth. Technology Analysis \& Strategic Management, vol. 27, issue 2, pp. 219-236.

Desai S., Motoyama Y. (2015). The regional environment: Indianapolis-insights from high-growth companies. Kansas City: Kaufmann Foundation. 28 p.

Dosi G. (1982). Technological paradigms and technological trajectories: A suggested interpretation of the determinants and directions of technical change. Research Policy, vol. 11, issue 3, pp. 147-162. 
Dunne T., Roberts M. J., Samuelson L. (1989). The growth and failure of US manufacturing plants. The Quarterly Journal of Economics, vol. 104, issue 4, pp. 671-698.

Dusek V. (2006). Philosophy of technology: An introduction. Malden: Blackwell Publishing. 256 p.

Duval R., de la Maisonneuve C. (2010). Long-run growth scenarios for the world economy. Journal of Policy Modeling, vol. 32, no. 1, pp. 64-80.

Easterly W., Levine R. (2001). It's not factor accumulation: stylized facts and growth models. World Bank Economic Review, vol. 15, no. 2, pp. 177-219.

Ellul J. (1964). The technological society. N. Y.: Vintage Books. 449 p.

Geroski P., Machin S. (1992). Do innovating firms outperform non-innovators? Business Strategy Review, vol. 3, no. 2, pp. 79-90.

Grübler A. (2003). Technology and global change. Cambridge: Cambridge University Press. 464 p.

Guarascio D. \& Pianta M. (2017). The gains from technology: new products, exports and profits. Economics of Innovation and New Technology, vol. 26, isssue 8, pp. 779-804. DOI: http://dx.doi.org/10.1 080/10438599.2016.1257446

Henderson V. (2003). Marshall's scale economies. Journal of Urban Economics, vol. 53, no. 1, pp. 1-28.

Hoogstra G. J., Dijk J., van (2004). Explaining firm employment growth: Does location matter? Small Business Economics, vol. 22, issue 3-4, pp. 179-192.

Li S. (2005). High tech spatial concentration: Human capital, agglomeration economies, location theories and creative cities. Louisville: University of Louisville. DOI: https://doi.org/10.18297/etd/824

Macpherson A., Holt R. (2007). Knowledge, learning and small firm growth: A systematic review of the evidence. Research Policy, vol. 36, no. 2, pp. 172-192.

Mensh G. (1979). Stalemate in technology: Innovations overcome the depression. Cambridge.

Nurmi S. (2004). Plant size, age and growth in Finnish manufacturing. Finnish Economic Papers, vol. 17, no. 1, pp. 3-17.

O'Riain S. (2004). The politics of high tech growth: Developmental network states in the global economy. Cambridge: Cambridge University Press.

Orlikowski W. (1992). The duality of technology: Rethinking the concept of technology in organizations. Organization Science, vol. 3, issue 3, pp. 398-427.

Peine A. (2008). Technological paradigms and complex technical systems- the case of smart homes. Research Policy, vol. 37, issue 3, pp. 508-529.

Perrow C. A. (1970). Organizational analysis: A sociological view. L.: Tavistock. 192 p.

Perrow C. A. (1967). Framework for the comparative analysis of organizations. American Sociological Review, no. 32, pp. 194-208.

Rogers E. M. (1962). Diffusion of innovations. 1st ed. N. Y.: Free Press.

Rumelt R. P. (1991). How much does industry matter? Strategic Management Journal, vol. 12, no. 3 , pp. 167-185.

Sasidharan S., Kathuria V. (2011). Foreign direct investment and R\&D: Substitutes or complements - a case of Indian manufacturing after 1991 reforms. World Development, vol. 39, no. 7, pp. 1226-1239.

Sukhodolov A. P., Beryozkin Yu. M. (2018). From the institutional to the platform economy. Upravlenets $=$ The Manager, vol. 9, no. 3, pp. 8-13. DOI: 10.29141/2218-5003-2018-9-3-2.

Tkachenko A., Yakovlev A., Kuznetsova A. (2017). 'Sweet deals': State-owned enterprises, corruption and repeated contracts in public procurement. Economic Systems, vol. 41, no. 1, pp. 52-67.

Tunzelmann G. N., von (2000). Technology generation, technology use and economic growth. European Review of Economic History, vol. 4, issue 2, pp. 121-146.

Uttley S. (1984). Reformulating the development theory of welfare. Journal of Social Policy, vol. 13, issue 4, pp. 447-465.

Venkatesh V., Morris M. G., Davis G. B., Davis F. D. (2003). User acceptance of information technology: Toward a unified view. MIS Quarterly, vol. 27, no. 3, pp. 425-478.

Voskoboynikov I. V. (2017). Sources of long run growth of the Russian economy before and after the global financial crisis. Russian Journal of Economics, no. 3 (4), pp. 348-365. DOI: https://doi.org/10.1016/j. ruje.2017.12.003

Woodward J. (1965). Industrial organization: Theory and practice. L.: Oxford University Press. 281 p. 
Woodward J. (1970). Industrial organization: Behavior and control. L.: Oxford University Press. 262 p.

Zúñiga-Vicente J. Á., Alonso-Borrego C., Forcadell F. J., Galán J. I. (2014). Assessing the effect of public subsidies on firm R\&D investment: A survey. Journal of Economic Surveys, vol. 28, issue 1, pp. 36-67. DOI: https://doi.org/10.1111/j.1467-6419.2012.00738.x

\section{Information about the author}

Andrey V. Misyura, General Director of Scientific and Production Association of Automatics named after academician N.A. Semikhatov, 145 Mamina-Sibiryaka St., Ekaterinburg, 620075, Russia; Postgraduate of Enterprises Economics Dept., Ural State University of Economics, 62/45 8 Marta/Narodnoy Voli St., Ekaterinburg, 620144, Russia

Phone: +7 (343) 214-80-40, e-mail: asp_avm@mail.ru

(C) Мисюра А. В., 2019 
Anquan Feng

\title{
The shale revolution and Sino-Russian energy cooperation
}

\begin{abstract}
With the progress of technology, the production cost of shale oil and gas will decrease again, and, in turn, the competitive advantage of shale oil and gas over conventional oil and gas exploitation will be enhanced. Obviously, this will lead to changes in the international oil and gas energy pattern. The paper discusses the impact of the shale revolution on the international energy market, and analyses the trends in Sino-Russian energy cooperation. Methodologically, the paper relies on a center of gravity theory as applied to oil and gas production and consumption. The main research method is comparative analysis of energy exports and imports between China and Russia under the development of technologies for shale oil and gas production. The impact of the shale revolution on China is increased number of channels of oil and gas import, increased exploitation of oil and gas resources, reduction in China's energy imports, and the country's stronger voice in the energy market. The impact on Russia is added competitive pressure in the energy market, and increased stimulus to exploitation of unconventional energy in Russia. The paper outlines prospects for Sino-Russian cooperation in oil and gas export and import given the emerging structure of the market, and lists obstacles in the way to successful cooperation between the countries.
\end{abstract}

Keywords: shale revolution; Russia; China; petroleum; natural gas; energy cooperation.

For citation: Feng A. Q. The shale revolution and Sino-Russian energy cooperation. Journal of New Economy, 2019, vol. 20, no. 4, pp. 108-118. DOI: 10.29141/2073-1019-2019-20-4-6

Received April 29, 2019.

\section{Introduction}

A $s$ the most important fossil fuel for the current industrial production and social develop-

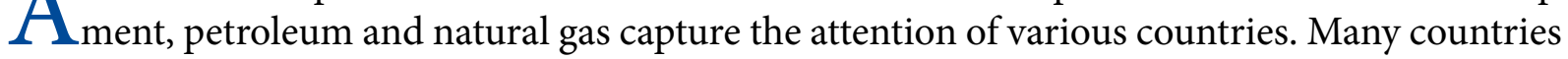
regard the supply of petroleum and natural gas energy as the essential component of national security. Some energy exporting countries utilize the petroleum and natural gas to obtain a benefit in the international relations. The supply of and demand for oil and gas energy has become an important issue in the competition among the great powers.

At present, the exploitation of shale oil and gas energy has developed into a significant factor affecting the world oil and gas energy production and the marketing pattern while the international conventional oil and gas resources exploitation areas are dominated by the world's oil giants. In recent years, the United States, which has always been known as a major importer and consumer of oil and gas, has started a large-scale shale oil and gas exploitation, which made the country an exporter of oil and gas. Although there are three countries, including the United States, Canada and China, now engaged in the commercial shale gas exploitation, the amount of shale gas produced in Canada and China is rather small to affect the pattern of the international natural gas market. Of them, only the United States is carrying out a large-scale commercial exploitation. Nonetheless, the shale revolution exerted a profound impact on the world energy supply. In the long term, with the popularization and improvement of the mining technologies, the shale revolution is going to have a greater and greater impact on the international oil and gas energy production and the marketing pattern. 
The purpose of the paper is to study the Sino-Russian oil and gas energy cooperation against the background of the shale revolution. The main tasks of the paper are to diagnose the basic situation with the shale revolution in the world today, examine its influence on the international energy pattern and the new situation of energy cooperation between China and Russia, and finally, to put forward suggestions for strengthening energy cooperation between the two countries.

\section{Basic condition of the shale revolution}

The shale revolution is sponsored and led by America in order to mine the unconventional oil and gas resources. After decades of exploration, America has achieved a breakthrough in the mining of shale oil and gas. In the past ten years, the output of shale gas has multiplied. Led by America, the scope of countries mining shale gas has expanded to Canada and China. However, in terms of the mining technology and scales, other countries could not fight with America for the leadership in the shale revolution.

At present, the technology for a large-scale commercial mining of shale oil is mainly mastered by America's oil enterprises. The United States have seriously decreased its import dependency on petroleum by mining shale oil. Although many countries regard the mining of shale oil as the important goal of local energy development, none of them, except for America, has achieved the scales of commercial development. The overall condition of storage and exploitation of shale oil and gas influenced the development of the international energy context. In the future, as the great powers possessing the shale resources master the necessary technologies, the shale revolution is going to create even larger impact on the international energy context.

The shale gas reserves in the world are mainly located in North America, Latin America, Central Asia, China, South Africa and the Middle East, where there are about 95 shale gas basins and 137 shale strata. The geological resources with risk are about 1,013 trillion $\mathrm{m}^{3}$, and the technically recoverable resources are about 220 trillion $\mathrm{m}^{3}$ [Men, Han, Wang, 2018]. The top ten countries by the amount of technically recoverable shale oil resources are presented in the Table.

Top ten countries by technically recoverable shale oil resources

Рейтинг стран по объему технически извлекаемых ресурсов сланцевой нефти

\begin{tabular}{|c|c|c|}
\hline Rank & Country & Technologically recoverable reserves (billion tonnes) \\
\hline 1 & Russia & 75 \\
\hline 2 & USA & 58 \\
\hline 3 & China & 32 \\
\hline 4 & Argentina & 27 \\
\hline 5 & Libya & 26 \\
\hline 6 & Venezuela & 13 \\
\hline 7 & Mexico & 9 \\
\hline 8 & Pakistan & 9 \\
\hline 9 & Canada & 8 \\
\hline 10 & Indonesia & \\
\hline
\end{tabular}

Source. US Energy Information Administration. Technically recoverable shale oil and shale gas resources: An assessment of 137 shale formations in 41 countries outside the United States. Available at: https://www.eia.gov/analysis/studies/worldshalegas/pdf/overview.pdf

America is both the leading country of the shale revolution and the largest beneficiary country. At present, America achieves self-sufficiency with oil and gas energy by mining the shale oil and gas. Just because America's shale oil and gas output sharply increases, the international energy situation changes. After the shale revolution, the United States overtook Saudi Arabia as 
the world's largest oil producer and boosted oil exports. Undoubtedly, this will challenge materially the traditional game rules and pricing models of the international oil market and exert a profound influence on the construction of the new oil order [O'Sullivan, 2017].

In 2009, America's natural gas output reached 624 billion $\mathrm{m}^{3}$, which surpassed the output of Russia, and America became the largest natural gas producing country in the world. In 2010, America's shale gas output increased to 100 billion $\mathrm{m}^{3}$, and its proportion in America's natural gas output increased to $20 \%$ from $1 \%$ five years ago [Wang, 2018]. In 2016, the shale gas output approximated to 420 billion $\mathrm{m}^{3}$, accounting for about $53 \%$ of America's natural gas output [Wang, Jin, 2018]. In 2017, the total natural gas output in the USA reached 936.6 billion $\mathrm{m} 3$, of which the shale gas output was 462.1 billion $\mathrm{m}^{3}(49.4 \% \text { of the total })^{1}$. With the opening of the relevant policies in America, the output of shale gas is likely to continue soaring.

China is the third largest shale gas producing country after the United States and Canada. In the new century, China is attaching more importance to the mining of shale gas. In the recent decade, the country has launched many plants for mining shale gas. However, the commercial mining of shale gas has been achieved only recently, and the quantity produced is rather small. In 2015, China's shale gas output reached 4.47 billion $\mathrm{m}^{3}, 3$ times higher than in the previous year before. In 2016, the output increased by almost $75 \%$ and reached 7.82 billion $\mathrm{m}^{3}$, accounting for $5.76 \%$ of the total output of the natural gas. In 2017, the output reached 9.1 billion $\mathrm{m}^{3}$ ( $6.4 \%$ of the total). Although the output of shale gas increases constantly, it is much less than the national planned and anticipated output. The state of reserves and technological capabilities for mining shale gas in China allow concluding that it is difficult to achieve a huge growth of the shale gas quantity in the short term.

The exploration and development of shale oil in China is late, and the complicated geological environment makes it even more difficult. At present, the exploitation of shale oil in China is still in its infancy and has not yet entered the stage of industrial exploitation. By 2016, PetroChina has drilled 686 wells and put 651 wells into operation in the test areas of Changqing and Daqing, producing 795,000 tonnes of shale oil in that year with cumulative total of 2.52 million tonnes of shale oil. According to the 13th Five-Year Plan for China's Energy Development, shale oil production is expected to reach 1 million tonnes by 2020 and achieve commercial breakthroughs. Yet at present, attaining this goal seems problematic.

Russia is the country with the largest reserves of shale oil. However, its conventional oil and gas reserves are still larger, and mining shale oil needs lots of capital and high technologies, hence the country mines shale oil on a very small scale. In 2017, the shale oil output reached 20,000 barrel/day [Chen, Wu, 2018]. As America's mining technology of shale oil becomes increasingly mature and the mining costs decline, Russia is paying more attention to the exploration and mining of the shale oil. In order to improve the enterprises' impetus for mining the shale oil, Russian government provides the corresponding preferential tax policy for enterprises ${ }^{2}$.

Gazprom has focused on the research and development of the shale oil mining technology, and is planning to carry out commercial production in the next few years. If the shale oil production goes smoothly, Russia's total oil and gas production will increase significantly. Since 2014, the Russian government has implemented a tax-free policy for the exploration and development of shale oil. At present, Gazprom has started a small-scale production in Siberia. In

\footnotetext{
${ }^{1}$ Natural Gas Research Center of Oil Observation Think-Tank. (2018). Meiguo tianranqi chanlian zaihuo zengzhang [Regrowth of America's natural gas output]. Tianranqi zhoukan = Natural Gas Intelligence Collection, vol. 38, pp. 59-62. (in Chinese)

${ }^{2}$ Yeyanyou chuxian zhengrong rechaolaidong ladong xinyilun youjia shangzhang [The shale oil is beginning to emerge. The boom has driven a new round of international oil prices]. Available at: http://www.sohu. com/a/227061335_100097967 (in Chinese)
} 
addition, the Rosneft Oil and BP signed a cooperation agreement to explore shale oil jointly in the Volga-Ural region.

\section{The shale revolution impact}

The shale energy revolution occurs when conventional fossil energy resources are exhausted. By now, only America has been able to master the mining technology of shale energy well enough to conduct the large-scale business development of the shale energy. All other countries will inevitably focus on mining the shale energy reserves on the Earth when the sources of conventional fossil energy are depleted. The shale energy revolution will create a powerful impact on the world energy situation, models of joint mining, and energy consumption.

America is the most successful country in the mining of the shale energy. By doing this, the country does not only efface the reputation of being the largest oil and gas importer, it becomes the net exporter of natural gas by mining the shale gas. In addition, its petroleum import dependency decreases year by year. The energy consumption of America as the first big economic power in the world is staggering. In 1948, America became the net importer of petroleum, and in 1998 , its import dependency went up to $51.6 \%$, which surpassed a $50 \%$ international warning line for the first time. At the beginning of this century, America's petroleum import dependency kept on going up and amounted to $66.3 \%$ (a peak value) in 2005. With the output of the shale oil increased, the country's import dependency started to decline. In 2010 and 2011, the import dependency decreased to $57.2 \%$ and $52.6 \%$ respectively [Yin, Zhang, 2013]. At the end of 2015, President Obama signed the bill and lifted the 40-year ban on crude oil exports. In 2017, America exported 170 million tonnes of crude oil, the net import volume decreased greatly, and the petroleum import dependency went down to $33.2 \%$, which was the lowest level over the past 60 years ${ }^{1}$. With the rising oil prices and the development of the shale oil mining technology, America's shale oil output will undoubtedly improve, and its export will rapidly increase.

If the production of shale oil reduces America's petroleum import dependency, the development of shale gas allows America to become a natural gas export power. In 2016, America was a net importer of natural gas, with the net import volume of 685 billion $\mathrm{ft}^{3}$, while in 2017 America became a net exporter of natural gas ${ }^{2}$.

The sources of oil and gas import for the United States were once located in highly volatile regions such as the Middle East and Africa, which undoubtedly threatened the US energy security. Through the shale energy revolution, the United States not only reduced its dependency on oil to a secure level, but also became a net exporter of natural gas, and the country's energy security situation has significantly improved. Therefore, the shale energy revolution not just guarantees the energy security of the United States, but also enables the American people to enjoy low oil and gas prices, reduces the cost of living and production, and enhances the competitiveness of enterprises. At the same time, through the shale revolution, the international influence of the United States strengthened further, and the impact on the international energy pattern became even greater. For energy exporters such as Canada and Argentina, the shale energy revolution will undoubtedly increase their oil and gas sources, ensure their adequate energy exports and promote their economic development. Though possessing large reserves of shale oil and gas, China is still at the initial stage of shale oil and gas exploitation, but with the improvement of the mining technology, a huge amount of shale energy reserves will ease the energy shortage in China.

The improvement of the shale oil mining technology significantly reduced the cost of mining

1 Wang N. Q. Shiyou duiwai yicundu $70 \%$ kepama?[ Is $70 \%$ import dependence of petroleum horrible?]. Available at: https://baijiahao. baidu. com/s? id =1599549775556453471\&wfr = spider\&for = pc (in Chinese)

${ }^{2}$ U.S. Natural Gas Imports \& Exports 2016. Available at: https://www.eia.gov/naturalgas/importsexports/annual/ 
shale oil in America. In 2014, the cost of mining equaled 60-70 US dollars per barrel, while in 2017, the cost decreased to less than 20 US dollars per barrel, which enhanced the international competitiveness of America's export petroleum, and will inevitably make the country race to control and increase its share in the international energy market.

In 2017, China's import of crude oil went up to 420 million tonnes, and China became the largest importer of crude oil in the world. Before 2017, China imported crude oil mainly from the Middle East, Africa, Russia, Central Asia and Venezuela, and China almost did not buy petroleum from the USA. In 2017, China imported 6.76 million tonnes of crude oil from America, which accounted for $1.6 \%$ of China's total crude oil imports. In the first quarter of 2018, China's crude oil imports from the United States rose sharply, accounting for $2.5 \%$ of China's oil imports in the same period ${ }^{1}$. With the increase of America's crude oil exports, China will import more crude oil from America in the future. The shale energy revolution will expand the energy import channels for China by diversifying energy import sources.

The shale energy revolution influences both importers and exporters of energy. Russia is the energy export power, and its economy severely depends on the petroleum and natural gas exports. In 2017, Russia's exports reached 357 billion US dollars, of which the fuel energy accounts for the bulk. The crude oil, petroleum products, and natural gas make up $38 \%, 24 \%$ and 14\% of total exports respectively. Although Russia takes measures and tries hard to change the situation when commodity export excessively depends on the energy, the effect is not obvious. Overall, for a long time in the future, Russia will not be able to change this situation and, hence, will be influenced by the shale energy revolution even more.

\section{Sino-Russian energy cooperation}

China and Russia have cooperated productively in the field of oil and gas resources for over twenty years. Sino-Russian energy cooperation does not only promote the countries' economic development, but also strengthens their strategic relations. However, the cooperation in field of energy suffers many setbacks.

Sino-Russian cooperation in the field of oil and gas resources could be described as "fruitful collaboration and lots of problems". In the last ten years, China and Russia have initiated many large oil and natural gas cooperation projects. In 2009, Sino-Russian petroleum companies signed a 20-year contract. Under the terms of the contract, Rosneft Oil is to export 15 million tonnes of crude oil to China through the oil pipeline in the Far East annually during 2011-2030. In 2013, Sino-Russian petroleum companies signed two petroleum contracts: one for 25 years and another for 5 years. Rosneft Oil will export 360 million tonnes of crude oil to China through the oil pipeline in the Far East within 25 years and re-export 35 million tonnes of crude oil to China within 5 years. In October 2013, Sinopec Group and Rosneft Oil signed the agreement, which specifies that Rosneft Oil is to export 10 million tonnes of crude oil to Sinopec Group every year during 2014-2023, and the sum of business transactions is predicted to reach 85 billion US dollars. Besides, in January 2017, they extended the Petroleum Purchase and Sale Agreement for another 35 million tonnes of petroleum within 5 years until the end of 2023, and the total volume increased to 91 million tonnes. In 2017, Rosneft Oil and CEFC China signed a 5-year petroleum contract. The contract specifies that CEFC China will purchase 60.8 million tonnes of petroleum from Rosneft Oil [Xu, 2016].

During the two decades of cooperation, Russia and China have not only developed the

${ }^{1}$ Zhongguo jinkou Meiguo yuanyou guimo tongbi dazeng 57 \% [China’s import of America's crude oil greatly increases by $57 \%$ on a year-on-year basis not due to the pressure from America]. Available at: http://baijiahao.baid. $\mathrm{com} / \mathrm{s}$ ? id $=1602608579421390009 \& w f r=$ spider\&for $=$ pc. $($ in Chinese $)$ 
petroleum trade from scratch, but also have changed the method of transportation from the single railway transport to the multi-channel transport with the use of railway, pipeline and marine transport. As can be seen from Figure, the countries' petroleum trade volume has increased rapidly. In 2016, China imported 52.5 million tonnes of petroleum from Russia, which accounted for $13.8 \%$ of the total petroleum imports. In 2017, China imported 59.7 million tonnes of the Russian petroleum, $13.7 \%$ more than in the year before, which accounted for $14.2 \%$ of China's total petroleum imports and $23.6 \%$ of Russia's total petroleum exports. Therefore, China became Russia's largest petroleum buyer. Since 2018, a Russia-China oil pipeline has been operating with full load, and Russia is going to export 30 million tonnes of crude oil to China through the pipeline every year [Sun, 2018].

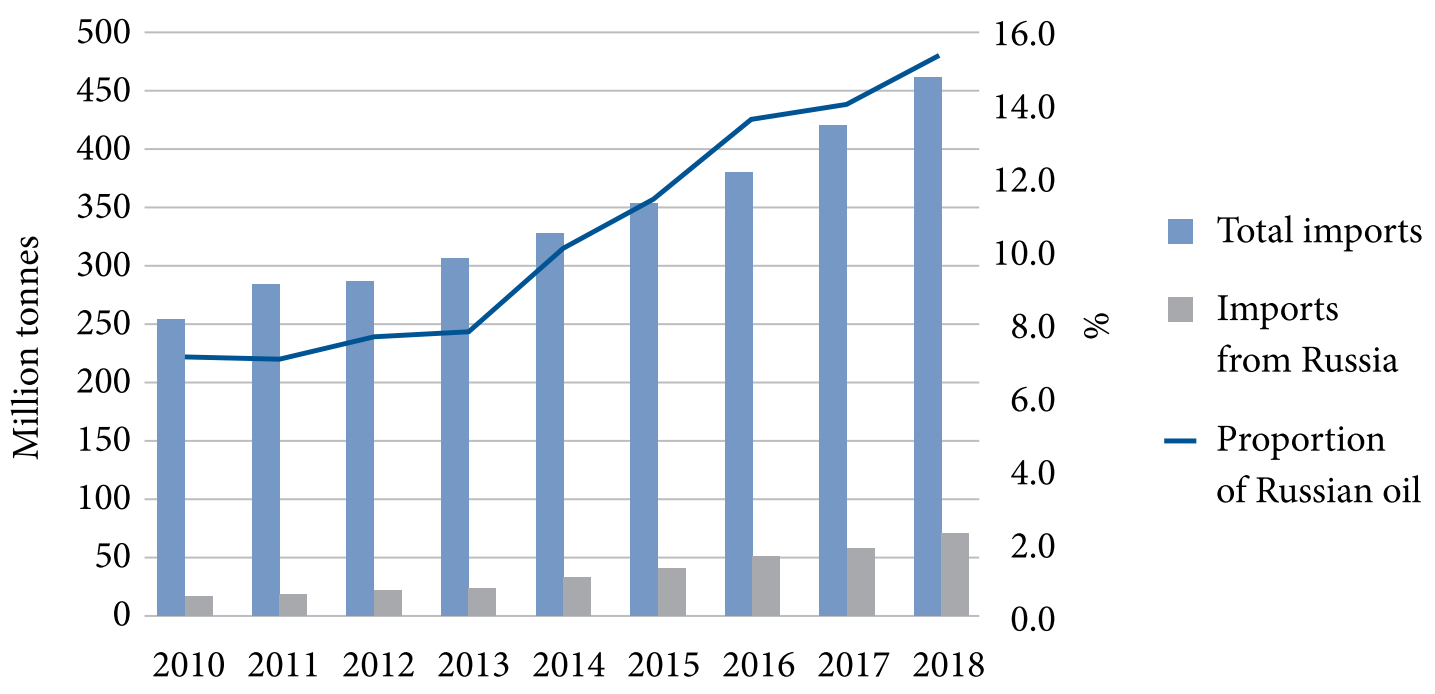

Sino-Russian oil trade in $2010-2018^{1}$

Динамика торговли нефтью между Китаем и Россией в 2010-2018 гг.

In the natural gas cooperation, China and Russia experience many problems. Although both countries have been discussing its issues for many years, only recently they have obtained certain progress. In May 2014, Gazprom and CNPC signed a gas supply agreement lasting for 30 years with the value of 400 billion US dollars. The contract specifies Russia will export 38 billion $\mathrm{m}^{3}$ of natural gas to China through the Power of Siberia gas pipeline from the end of 2019. In addition, in November 2014, CNPC and Gazprom signed the Framework Agreement on Gas Supplies via Western Route. The agreement specifies that Gazprom will export 30 billion $\mathrm{m}^{3}$ of natural gas to China annually within 30 years after the completion of the western line. If the agreement is executed, China will surpass Germany and become Russia's largest natural gas importing country.

China and Russia also achieved certain progress in joint refining of oil and gas by developing the downstream. In 2013, the agreement signed by the Government of the Russian Federation and the Government of the People's Republic of China established the cooperation in the construction and operation of the Tianjin Refinery and Petrochemical Plant. In May 2014, CNPC and Rosneft signed Work Schedule for Tianjin Refinery and Petrochemical Plant, which contains the plans to put the plant into operation before the end of 2019. In September 2013, CNPC and NOVATEK, Russia's second largest natural gas company, signed the agreement on the Yamal Cooperation Project. The project is the largest Arctic LNG project globally. According to the agreement, the CNPC purchased a $20 \%$ share in Yamal LNG project. The project aims at the annual output of 16.5 million tonnes of LNG, of which over 4 million tonnes are going to be

\footnotetext{
${ }^{1}$ Source. China General Administration of Customs. China Customs Statistics Yearbook. Beijing: China Customs Publishing Press, 2010-2018.
} 
transported to China. In November 2014, CNPC and Rosneft officially signed the cooperation framework agreement on the Vankor Oilfield project. Under the agreement, CNPC purchased a $10 \%$ share in the Vankor project. The countries also achieved a breakthrough in the upstream cooperation. In 2017, the countries agreed about a joint project, which will be implemented by the Vostok Petrochemicals joint venture ( $49 \%$ Rosneft, 51 \% CNPC). Through this venture, Rosneft Oil finally enters the PetroChina processing. The joint venture is meant to be put into operation in 2021, and the capacity is planned to reach 16 million tonnes annually, of which more than 9.1 million tonnes oil will be from Russia [Matveyev, 2018].

China has become the largest petroleum importer in the world, its petroleum import dependency approximates to $70 \%$, whereas its natural gas import dependency reaches $39.2 \%$. Based on the current consumption of oil and gas in China, its import dependency on petroleum will keep on growing, which creates an increasingly severe energy security situation for the country. As for Russia, the country is the largest energy exporter in the world, and its economy significantly depends on the export of oil and gas resources, therefore, higher energy prices and diversified energy export markets are important for maintaining the national economic security. The analysis of energy security strategies of both countries allows concluding that they have both areas of common interest and apparent contradictions. Hence, they could cooperate better only by thinking rationally, handling issues with sincerity and carefully considering the benefits.

Being the neighbours, China and Russia could strengthen their energy cooperation based on the complementarity. Strengthening the energy cooperation between the countries is of great significance for maintaining their energy security. On the one hand, Russia is a reliable supplier of the increasing amount of oil and gas resources for China. On the other hand, the oil and gas export to China meets the goals of Russia's strategy of energy export diversification and helps avoid subjection to European customers. Hence, strengthening the Sino-Russian oil and gas cooperation contributes to the energy security of both countries.

With regard to the security of the energy import channel, the Russia-to-China channel is the most secure. In addition, China could spend less in terms of transport expenses when importing energy from Siberia and the Far East areas, which allows the country to reduce the costs of importing oil and gas resources. Hence, it is of great significance to strengthen the oil and gas resources cooperation between Russia and China. Undoubtedly, the shale energy revolution does more good than harm for energy importers like China. The growth of shale oil and gas output gradually transfers the oil and gas resources from the sellers' market to the buyers' market to some extent, improves the importer's bargaining power (China) and allows Russia largely abandon the impractical economic desire. If both countries could see the shale oil and gas impact on the international energy market clearly, their energy cooperation will strengthen further.

Currently, the shale revolution is successful only in America, and is not brought about globally. Although China and Russia are the shale oil and gas reserves powers, they have not mastered the technology for mining the shale oil and gas under complicated geological conditions very well as yet. Hence, they could reduce the cost of mining the shale energy by forming an interest-based community of shale mining within two countries to jointly explore and mine the shale oil and gas resources, which would certainly make both countries cooperate more closely in the field of energy resources.

In addition, China should boost investment in capital and technology, make its shale oil and gas production technology mature as soon as possible, reduce production costs, and thus reduce the dependency on foreign oil and gas resources. Only in this case Russia will be able to grasp the reality and become enough motivated to show more initiative in oil and gas resources cooperation with China. Past experience has taught us that the greater China's dependency on Russia's energy is, the more passive the energy cooperation becomes. The major 
petroleum agreements signed by China and Russia clearly reflect the Chinese party's helplessness and the Russian party's dominance while distributing the oil transportation price between the two countries. For example, China and Russia signed an agreement on the crude oil export to China through the Far East oil pipeline. China believes that the destination of Russian oil exports to China is Skovorodino (Russia), and that China's payment of transportation costs to Russia should also be the cost of the mileage from Tayshet to Skovorodino. Russia, on the other hand, argues that its oil is exported to the countries of the Far East. Even if the Chinese party does not buy it, South Korea and Japan will buy it. The Chinese party is required to pay for the transportation in the entire Far East oil pipeline (the full mileage from Tayshet to the port of Kozmino at the coastal frontier), even if the oil to China does not pass through the section from Skovorodino to Kozmino. The Chinese party also has to pay the transportation fee, which reaches about 30 US dollars per ton. From a commercial viewpoint alone, Russia's requirements are unreasonable.

The overall picture seems to be that the Sino-Russian energy cooperation is very smooth when the situation in Russia is relatively passive, or diversification of the energy markets encounters problems. When the situation in international energy market is tense, and the oil and gas market is the seller's market, the energy cooperation between the two countries starts to suffer setbacks. Therefore, China had better to increase the shale oil and gas production. Obviously, China should not only increase the shale oil and gas exploitation, but also reduce the exploitation cost of these resources. Only by doing this China will be able to reduce the dependency on foreign oil and gas resources, strengthen its position in oil and gas cooperation with Russia, and make Russia enhance its enthusiasm and initiative in energy cooperation with China.

The enhancement of mutual political trust between China and Russia is the major power for promoting their oil and gas resources cooperation. Since the independency of Russia, the political and economic relations between China and Russia have been developing actively. Politically, both countries have established the comprehensive strategic partnership. In terms of economy and trade, China has acted as the largest trade partner of Russia for many years. Consequently, good political and economic relations of both countries are an important impetus for promoting cooperation in other fields.

\section{Conclusion}

The shale gas revolution in the USA and the global shale gas bias will accelerate the process of westward movement of global oil and gas production centers and eastward movement of consumption centers, weaken Russia's power in the international natural gas market to a certain extent, and force it to pay more attention to the Far Eastern market. Profound changes in the international energy pattern caused by the shale gas revolution may create new opportunities for the Sino-Russian energy cooperation, and accelerate the eastward shift of the Russian natural gas exports. The attractive prospects of an increase in the shale gas production in China are going to have a positive effect on the development of the Sino-Russian energy cooperation. Against the background of the shale gas revolution, for China it is advisable to keep an eye on Russia's energy strategies; build political trust; promote Sino-Russian energy cooperation at multiple levels with a particular focus on the energy prices; pay meticulous attention to the Sino-Russian energy cooperation in contiguous areas; promote the utilisation of the unconventional energy and introduction of the energy saving and emission reduction technologies. 


\section{References}

Chen X. L., Wu X. (2018). Yeyan geming beijingxiade ZhongE youqi nnengyuan hezuo [Sino-Russian oil and gas energy cooperation against the background of the shale revolution]. Xiboliya yanjiu $=$ Siberian Studies, vol. 3, pp. 45-53. Available at: http://www.cnki.net (in Chinese)

Matveyev B. A. (2018). Shijie nengyuan shichang fazhan qushi he Zhong E nengyuan hezuo [Development tendencies of world energy market and Sino - Russian energy cooperation]. Ouya jingji yanjiu = Russian, East European \& Central Asian Studies, vol. 3, pp. 96-99. Available at: http://www.cnki.net (in Chinese, transl. by Nong Xuemei)

Men X. X., Han Z. H., Wang L. (2018). Yeyanqi ziyuan kantan kaifa lishi ji xianzhuang [History and current situation of exploration and development of shale gas resources]. Xinjiang shiyou dizhi=Xinjiang Petroleum Geology, vol. 6, pp. 372-376. Available at: http://www.cnki.net (in Chinese)

O'Sullivan M. L. (2017). Windfall: How the new energy abundance upends global politics and strengthens America’s power. N.Y.: Simon \& Schuster. 496 p.

Sun Y. X. (2018). Eluosi zai guoji nengyuan geju zhong rengshi qiangguo diwei [Russia is still in great power status in international energy layout]. Ouya jingji yanjiu = Russian, East European \& Central Asian Studies, vol. 3, pp. 72-76. Available at: http://www.cnki.net (in Chinese)

Wang E. D., Jin Z. J. (2018). Zhongguo yichengei shijie disanda yeyanqi shengchanguo dan yeyanyou geming yuanwei daolai [China has become the third largest shale gas production country in the world, but the shale oil revolution has not come yet]. 21 shiji jingji baodao $=21^{\text {st }}$ Century Business Herald. Available at: http://www.cnki.net (in Chinese)

Wang Y. (2018). Genfeng meiguo yeyanqi de shifei [Right and wrong aspects of following the trend of America’s shale gas]. Nengyuan = Energy, vol. 3, pp. 52-55. Available at: http://www.cnki.net (in Chinese)

$\mathrm{Xu}$ H. F. (2016). Pujing disan renqi yilai Zhong E nengyuan hezuo xinjinzhan ji qianzai zhangai [New progress and potential barriers of Sino - Russian energy cooperation since the third tenure of Putin]. Eluosi zhongya dongou yanjiu = Russian, East European \& Central Asian Studies, vol. 6, pp. 60-65. Available at: http://www.cnki.net (in Chinese)

Yin J. P., Zhang J. (2013). Meiguo nengyuan duiwai yichundu de bianhua jiqi qishi [Change and enlightenment of import dependency of America's energy]. Dui wai maoyi wush = Foreign Economic Relations and Trade, vol. 7, pp. 23-25. Available at: http://www.cnki.net (in Chinese)

\section{Information about the author}

Anquan Feng, PhD (Economics), Assistant Prof. of Applied Economics Dept., Heilongjiang Academy of Social Sciences, 1000 Shibo Road, Songbei District, Harbin, 150028, China

Phone: +86-136-4431-3861, e-mail: anquanf@hotmail.com 


\title{
Сотрудничество России и Китая в условиях сланцевой революции
}

\begin{abstract}
Аннотация. По мере технического прогресса стоимость производства сланцевых нефтегазовых ресурсов снижается, что увеличивает их конкурентоспособность. Данный факт изменит структуру международного рынка нефтегазового сырья. Представленное исследование посвящено анализу влияния сланцевой революции на международный энергетический рынок и выявлению тенденций энергетического сотрудничества Китая и России. Методологической базой исследования послужила концепция пространственного смещения центров добычи и потребления нефтегазовых ресурсов. Основной метод исследования - сравнительный анализ динамики экспорта и импорта энергетических ресурсов Китая и России в условиях развертывания сланцевых технологий. Влияние сланцевой революции на Китай отразилось в увеличении числа каналов импорта нефти и газа, росте показателей объема добычи нефти и газа, сокращении импорта энергии и усилении роли страны на международных энергетических рынках. Влияние на Россию заключается в повышении конкурентного давления на энергетических рынках и росте стимулов к использованию нетрадиционных источников энергии в стране. Результатом исследования является определение перспектив российско-китайского сотрудничества в сфере экспорта и импорта нефти и газа с учетом формирующейся структуры рынков, а также препятствий к успешному взаимодействию.
\end{abstract}

Ключевые слова: сланцевая революция; Россия; Китай; нефть; газ; энергетическое сотрудничество.

Для иитирования: Feng A. Q. Shale revolution and Sino-Russian energy cooperation // Journal of New Economy. 2019. T. 20, № 4. C. 108-118. DOI: 10.29141/2073-1019-2019-20-4-6

Дата поступления: 29 апреля 2019 г.

\section{Источники}

Chen X. L., Wu X. (2018). Yeyan geming beijingxiade ZhongE youqi nnengyuan hezuo [Sino-Russian oil and gas energy cooperation against the background of the shale revolution]. Xiboliya yanjiu $=$ Siberian Studies, vol. 3, pp. 45-53. Available at: http://www.cnki.net (in Chinese)

Matveyev B. A. (2018). Shijie nengyuan shichang fazhan qushi he Zhong E nengyuan hezuo [Development tendencies of world energy market and Sino - Russian energy cooperation]. Ouya jingji yanjiu = Russian, East European \& Central Asian Studies, vol. 3, pp. 96-99. Available at: http://www.cnki.net (in Chinese, transl. by Nong Xuemei)

Men X. X., Han Z. H., Wang L. (2018). Yeyanqi ziyuan kantan kaifa lishi ji xianzhuang [History and current situation of exploration and development of shale gas resources]. Xinjiang shiyou dizhi=Xinjiang Petroleum Geology, vol. 6, pp. 372-376. Available at: http://www.cnki.net (in Chinese)

O'Sullivan M. L. (2017). Windfall: How the new energy abundance upends global politics and strengthens America's power. N.Y.: Simon \& Schuster. 496 p.

Sun Y. X. (2018). Eluosi zai guoji nengyuan geju zhong rengshi qiangguo diwei [Russia is still in great power status in international energy layout]. Ouya jingji yanjiu = Russian, East European \& Central Asian Studies, vol. 3, pp. 72-76. Available at: http://www.cnki.net (in Chinese)

Wang E. D., Jin Z. J. (2018). Zhongguo yichengei shijie disanda yeyanqi shengchanguo dan yeyanyou 
geming yuanwei daolai [China has become the third largest shale gas production country in the world, but the shale oil revolution has not come yet]. 21 shiji jingji baodao $=21^{\text {st }}$ Century Business Herald. Available at: http://www.cnki.net (in Chinese).

Wang Y. (2018). Genfeng meiguo yeyanqi de shifei [Right and wrong aspects of following the trend of America's shale gas]. Nengyuan = Energy, vol. 3, pp. 52-55. Available at: http://www.cnki.net (in Chinese)

$\mathrm{Xu}$ H. F. (2016). Pujing disan renqi yilai Zhong E nengyuan hezuo xinjinzhan ji qianzai zhangai [New progress and potential barriers of Sino-Russian energy cooperation since the third tenure of Putin]. Eluosi zhongya dongou yanjiu = Russian, East European \& Central Asian Studies, vol. 6, pp. 60-65. Available at: http://www.cnki.net (in Chinese)

Yin J.P ., Zhang J. (2013). Meiguo nengyuan duiwai yichundu de bianhua jiqi qishi [Change and enlightenment of import dependency of America's energy]. Dui wai maoyi wush = Foreign Economic Relations and Trade, vol. 7, pp. 23-25. Available at: http://www.cnki.net (in Chinese)

\section{Информация об авторе}

Фэн Аньцюань, $\mathrm{PhD}$ (Economics), доцент кафедры прикладной экономики Академии общественных наук провинции Хэйлунцзян, 150028, КНР, Харбин, р-н Сун Бэй, ул. Шибо, 1000 Контактный телефон: +86-136-4431-3861, e-mail: anquanf@hotmail.com

(C) Feng A. Q., 2019 
Vladimir A. Koksharov

Berik K. Dzhamanbalin
Ural State University of Railway Transport, Ekaterinburg, Russia Ural Federal University named after the first President of Russia Boris N. Yeltsin, Ekaterinburg, Russia

\title{
Strategic assessment of electric power industry development: A case of Kazakhstan
}

\begin{abstract}
Despite the stability of Kazakhstan's economy there is a need for objective and comprehensive research into the problems of the country's electric power industry management. The study aims to identify priority problems hindering electric power industry development in Kazakhstan based on modelled strategic assessments. The methodological basis of the research includes the concepts of strategic management applied at a macrolevel. In terms of the methods the authors rely on the multidimensional ranking procedure, which allows setting priorities for the industry development in compliance with the key objectives of the country. The proposed methodological framework for identifying the priority problems aims to improve the quality of the considered stage of devising strategic plans for the industry development. It has to firstly, make the selection of the main problems faced by the industry more objective; secondly, standardise and formalise the selection procedure as much as possible, i.e. adapt it for application not merely in the electric power industry, but in all other major sectors of the economy. The results of the research confirm that the proposed model linking the electric power industry development and the country's economic growth and competitiveness is of practical use.
\end{abstract}

Keywords: dynamic normal; competitiveness; power consumption; energy intensity; energy saving; energy efficiency.

For citation: Koksharov V. A., Dzhamanbalin B. K. Strategic assessment of electric power industry development: A case of Kazakhstan. Journal of New Economy, 2019, vol. 20, no. 4, pp. 119-132. DOI: 10.29141/2073-1019-2019-20-4-7

Received February 26, 2019.

\section{Introduction}

$\mathrm{K}$ azakhstan's economy industrialisation that involves the development of energy-intensive industries causes problems for the electric power industry. In this regard, it is particularly important to define priority problems to achieve sustainable and competitive development of the country's economy. However, currently applied methods have flip sides making such prioritisation impossible. The main deficiencies are as follows:

- effectiveness of the organisational and financial form of the industry is determined by external factors independent of the industry [Pfantsagl, 1976; Rakitskiy, Ustinov, Chernorutskiy, 1979];

- complicated and time-consuming decision-making [Klyuev, 2018];

- each problem has to be expressed through some final industrial criterion with respect for the importance of all other criteria included while, at the same time, it is difficult to reduce all models to the target function in an unbiased manner [Makarov et al.,1984; Melentev, 1982; Okorokov, 1976; Padalko, 1979; Tsisar, Neyman, 2002; Kendall, 1955];

- traditional methods of expert assessment cannot correlate the problems of the industry directly with the country's objectives [Pfantsagl, 1976; Rakitskiy, Ustinov, Chernorutskiy, 1979]; 
- reliance on comparing the variation series suggested by different experts [Mirkin, 1974; Suppes, Zinnes, 1967; Syroezhin, 1980] ${ }^{1}$.

Economic theory [Germeyer, 1971; Dukenbaev, 1998; Kornyakov, 2000; Revenkov, 2001; Fraser, 1999] suggests that the degree to which the state and the private sector are involved in the administration generally affects the competitive environment created in the industry and in the country.

From such a perspective, the study aims to develop a fundamentally new methodological approach to assess the priority problems of electric power industry development.

The authors assume that hypotheses are necessary to be formulated to prove that the assessment of priority problems faced by the electric power industry can help identify the interconnections in the fields of energy efficiency, energy saving, environmental protection, and market relations between energy producers and consumers in order to ensure economic growth and competitiveness of the country; develop and test a framework for carrying out a dynamic assessment of the electric power industry development strategy.

The scope of the questions raised in connection with the purpose of the study included the following:

- how to provide energy services at a reasonable price to ensure the sustainable development of the economic sectors;

- what are the ways to improve energy efficiency in all sectors of the country's economy;

- how to reduce harmful impact of the greenhouse gases and other waste of energy production on the environment;

- what are the ways to increase reliability of electric power supply, energy security, and energy policy prioritisation.

When designing the development strategy for an individual energy provider, it should be taken into account: a. the problems of the country and the industry as a whole; b. the possibility of optimising the financial and organisational structure of the enterprises in the industry in terms of improving their competitiveness, intensity of innovation, and scale of potential investments.

To make an objective selection of the key final indicators of the region's electric power industry development a number of significant indicators were analysed such as the region's investment attractiveness; competitiveness of a certain group of enterprises (by industry); and scale of innovation [Bobylev, Zakharov, 2011] $]^{2}$. The scale of investment, and a number of other indicators were rejected because they represent a means of solving some more important task. At the state level, there are two of the most critical "conceptual" and, therefore, hardly contestable goals, namely to ensure security (or "sufficient defence capability"); and to raise the standard of living of the country's population. At the regional level, there remains one indisputable goal: to raise the living standards in the region. Of course, the aforementioned means of achieving this goal can and even should be present on the model maps.

As a first step of the methodological approach, the most exhaustive record of industry problems is made using the most comprehensive list of information sources to avoid "gaps" in the problem analysis at the following steps.

To make the selection of industry problems more objective, our first idea is:

- to take into consideration the goals and main problems of the country ("super goals"), i.e. the country should take priority over the industry (at the same time, the traditional methods used to identify the problems faced by the industry are not rejected but serve as a possible

${ }^{1}$ Also refer to: Electricity reform in APEC economies - the way ahead. A review for the APEC Energy Working Group of APEC's. (2003). India: Oxford Institute for Energy Studies.

${ }^{2}$ Also refer to: [Volgin, Kushlina, 2001]. 
addition to the proposed approach and, therefore, should be seamlessly integrated into the general selection framework);

- to take account of the industry's organisational goals, especially those related to the interest held in the industry by the state and the private sector;

- to use the existing rating information that is "free" and yet scarcely used to improve the process of management: this particularly concerns the fairly objective world competitiveness rankings (Global Competitiveness Index);

- to use the cognitive mapping technique to correlate the consequences of solving (or not solving) the problems of the industry with the "distant" (by their level in the governing hierarchy) super-goals of the country;

- to provide clear algorithms for all calculations and constructs.

To standardise the problem selection procedure, the second idea is:

- to formalise the interrelations between the goals of the country and those of the industry as much as possible;

- to formalise the interrelations between the problems and organisational objectives of the industry as well as between the problems of the industry and its organisational and financial form as much as possible (using the elements of graph theory and the theory of expert assessments);

- to provide clear algorithms for all calculations and constructs.

The third idea suggested in the study is to make the selection algorithm of the problems of the industry less complicated by picking out the issues in three successive screening stages. At the first stage, the problems of the industry are arranged in order of priority from the perspective of one of the most important economic goals of the country, namely the competitiveness. At the second stage, the previously selected problems are sorted by importance in the context of the set of closely related goals of the industry (this set of goals is closely related to the organisational and financial form of the industry's operation). At the third stage, part of the problems picked out before (especially when the effects of their solving or not solving are ambiguous) pass through another filter and are ranked by the strength of their influence on the ultimate, top-level goals of the country.

Thus, the three consecutive selection filters are arranged, firstly, in the order of ascending labour intensity of selection procedures and, secondly, in a way that allows for consecutive decrease in the range of the selection to avoid unnecessary work when using the entire selection algorithm.

\section{Hypotheses underlying the conceptual approach}

Based on previous research and propositions, we formulate the following hypothesis to be tested.

H1: There is a rational relationship between the assessment of the problems faced by the electric power industry and the economic growth and improvement of the living standards within the framework of the proposed conceptual approach.

Energy supply, its ability to meet social needs, production efficiency, and the cost of energy and fuel are the most important prerequisites and drivers of economic growth in general and the progress of productive forces in particular. Energy supply is the most important factor in environmental management, especially where it is associated with the development of non-renewable resources and condition of the living environment. From this perspective, primary energy problems of the electric power industry development can be quite legitimately classified as crucial which require an effective solution to ensure the country's economic growth and competitiveness. However, the study of these energy problems needs to be specific and take into account the level of development of the productive forces, social relations, and specificity of the interrelation between energy supply and economic growth in its various types and at different stages [Barkin et al., 2014]. 
Such an approach allows us to properly distinguish between technical and economic maturation and exacerbation of the electric power industry development problems, and to differentiate their manifestations by individual periods and production industries. It is especially important when analysing problems at the current stage, as it can help evaluate the alternatives for the electric power industry, which undoubtedly has theoretical, political, and practical importance.

In its most general form, the relationship between energy consumption and economic growth is determined by the attained level of production development and the nature of productive relations. The type of economic growth is of considerate importance as well. When it is extensive, propelling new economic resources into production, specific energy consumption tends to grow faster than in the case of intensive growth that generally has a material-saving nature.

Electric power consumption is an important indicator of the quality of life, closely related to the growth rate and structure of the economy. Therefore, by analysing specific electric power consumption by the main sectors of Kazakhstan's economy, we can identify the key factors determining the dynamics of specific electric power consumption in the forecast period. In ferrous metallurgy, growth in electric smelting is compensated by total energy saving; in the aluminum industry, modern plants are built using new technologies, while in other non-ferrous metal industries, total energy saving is compensated by increased added value. In the petroleum refining industry, increased refinery yield and improved quality of petroleum products increase specific electric power consumption. In the coal industry, growth of energy consumption is due to introduction of new coal washing technologies.

In mechanical engineering, the main factors affecting specific energy consumption include the following. Specific energy consumption is reduced due to the introduction of the new, less power-intensive metal processing technologies. The industry-average savings are estimated at 20-30 \% [Germeyer, 1971]. Specific energy consumption is also reduced as a result of a growing number of assembly plants where energy-intensive assembly is not the main production process, and a significant part of manufacturing is performed in other countries. A larger share of metal-intensive and energy-intensive processing also decreases specific energy consumption of the engineering industry. Such a factor as the rise in the cost of engineering products due to their improved quality, consumer properties, and increasing emphasis on high technology causes the specific energy consumption to fall when calculated as part of the manufactured unit cost [Kendall, 1955].

Global experience demonstrates that economic growth is traditionally accompanied by an increase in electric power consumption [Volgin, Kushlina, 2001]. The relationship between the economic growth rates and electric power consumption is characterised by the elasticity coefficient (increase in electric power consumption by $1 \%$ of the GDP growth) the value of which depends on the nature of development and structure of the economy. The obvious connection between the electric power industry and economic growth is forcing the developing countries to increase their energy assets [Barkin et al., 2014]. The main factor behind the growing demand for electricity is the growth of industrial production [Vaynzikher, 2008].

Based on previous research, we formulate the following hypothesis to be tested:

H2: There is a rational relationship between the assessment of the problems faced by the electric power industry and the shortage of energy resources, economic growth, and competitiveness of a country within the framework of the proposed conceptual approach.

Today, there are the problems in the electric power industry that affect the sustainable economic development of Kazakhstan and hamper the country's competitiveness on the global market:

- lack of energy resources and electricity;

- threat of environmental pollution due to human impact of electric power facilities; 
- choice of a business model for the electric power industry operation.

The first problem relates to the fact that today's main energy resources are non-renewable, and are unevenly distributed across Kazakhstan. There are two ways to ensure energy security.

The first way is to search and develop domestic non-renewable and renewable energy resources. Incredible as it may seem, the energy-abundant states may also face problems with energy resources, as there is a real opportunity to live off the resource rent. There is every reason for this, as the volume of oil production is planned to be increased to 107.3 million tonnes by 2025 , and gas production - to 77.3 billion $\mathrm{m}^{3}$. The annual oil refining output will be increased to about 17 million tonnes to ensure production of petroleum products per environmental standards. In terms of potential coalbed methane resources, Kazakhstan is among the top ten countries in the world. Upon completion of exploration and appraisals, gas reserves will be placed on the state balance sheet. Strategic importance of having this problem assessed suggests the following approach.

The Caspian Pipeline Consortium's Oil transport expansion project has been completed in Kazakhstan with the participation of Russia, Kazakhstan, and leading mining companies. The pipeline transporting more than two thirds of Kazakhstan's total oil exports stretches for $1,511 \mathrm{~km}$.

In Kazakhstan, more than $70 \%$ of gas is produced by foreign investors from the United States, China, Russia, and the EU countries represented by large national and transnational companies such as ExxonMobil, Chevron, BP/Statoil, Shell, Total, INPEX, Philips, LUKOIL, and others.

There is an overall positive trend in the target indicators of gas production, considering the scheduled geotechnical efforts taken to increase gas production and expand associated petroleum gas processing capacity. One of the promising areas of gas industry development is advanced gas processing intended to produce gas chemical products with high added value.

The second way is to improve energy saving and energy efficiency, since energy-deficient countries are forced to spend a significant part of GDP to purchase energy resources, which has a negative effect on the economy and social sphere. Implementation of this method involves the following.

The objectives set in the Strategic plan for development of the Republic of Kazakhstan until the year 2020 and the Concept for transition of the Republic of Kazakhstan to Green Economy are intended to reduce the energy intensity of the country's GDP by $25 \%$ by 2020 and at least twice by 2050 (relative to 2008). As of the end of 2017, the country's energy intensity of the GDP has been reduced by $18 \%$ compared to 2008 .

In 2016, the World Bank performed an assessment of government regulation of energy efficiency across 111 countries. The Republic of Kazakhstan ranked the 32nd. By 2020, the country plans to improve its performance by $25 \%$, and then Kazakhstan will be able to enter the top thirty countries, and reach the top twenty by 2050, if it doubles its performance. According to the survey performed by the International Energy Agency, Kazakhstan ranks the 119th out of 143 countries by energy intensity of GDP. At the same time, Kazakhstan's GDP energy intensity is twice as high when compared to the world average and four times as high when compared to the OECD member countries; among the CIS countries, Kazakhstan ranks the fifth.

The basis of the modern energy saving system was formed in 2012-2015 as part of the first five-year period of industrial innovative development of Kazakhstan. Taking the experience of Japan into account, the State Energy Register has been created as a key element of the energy saving system. It currently includes more than 5,000 organisations. In 2016, the Ministry of Investment and Development of the Republic of Kazakhstan started to digitise energy efficiency indicators by setting up the Automated Information System of the State Energy Registry. In 2018, the system was launched in pilot mode, and $40 \%$ of all the members of the State Energy Registry provided information in the electronic form. The system is planned to be enshrined 
at the statutory level. The energy efficiency measures taken have already stabilised the level of energy intensity in the country (Fig. 1).

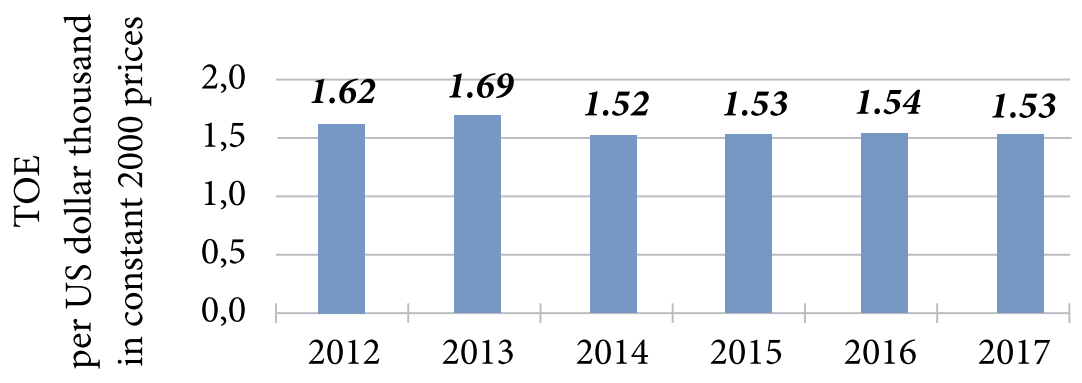

Fig. 1. The energy intensity of the Republic of Kazakhstan's GDP,

TOE per US dollar thousand in constant 2000 prices $^{1}$

Рис. 1. Энергоемкость ВВП в Республике Казахстан, т.н.э. на тьс. долл. США в ценах 2000 г.

It is self-evident that the lack of energy resources will be a deterrent to the country's economic growth, as, to deliver the production target per sector of the economy, plant capacities will either be underloaded or will fail to meet the demand. Therefore, the economies of scale will not reach their fullest potential, which will affect the cost of products and services, and this in turn will impact the competitiveness. Most experts believe that, under any anticipated scenario of the electric power industry development, the problem of meeting the growing demand for fuel and energy at reasonable prices and with minimal damage to the environment can be dealt with by implementing the concepts of energy saving and energy substitution, coupled with both building up the use of traditional fuels and involvement of alternative fuel resources into the energy production. The energy saving concept is implemented through the more efficient handling of the energy resources at all stages of their lifecycle: prospecting - survey - electrical and thermal energy production - transportation to consumers - consumption. At the same time, the presumption is that the existing problems of the electric power industry development will distort the pattern of economic growth and competition and cause a decrease in the industry efficiency.

Based on previous research, we formulate the following hypothesis to be tested.

H3: There is a rational relationship between the assessment of the problems faced by the electric power industry and the threat of environmental pollution due to the human impact created by electric power facilities, the economic growth, and the country's competitiveness within the framework of the proposed conceptual approach.

The second problem, which is of the environmental concern, progresses with the growing scale of the electric power industry development, and this scale and the technologies applied lead to the fact that $50 \%$ of the man-made emissions into the atmosphere come from electric power facilities. The government of Kazakhstan is taking the following organisational and economic steps: it cooperates with the European Bank for Reconstruction and Development on investments in renewable sources of energy. The bank has an opportunity to support the economy of Kazakhstan by supplying the investments and advising the authorities on economic reforms. The bank has invested about half a billion euros over the period of its operation in Kazakhstan. $57 \%$ of investments under 17 projects it has implemented in Kazakhstan were targeted at developing green economy in the country.

The Government of Kazakhstan has sent a national application to the UN Green Climate Fund. If approved, it will ensure the country's access to the fund's resources to attract finance

${ }^{1}$ Source. Energy intensity of the processing industry in the Republic of Kazakhstan. Available at: http://comprom.miid.gov.kz/ru/pages/energoemkost-obrabatyvayushchey-promyshlennosti-respubliki-kazahstan. (in Russ.) 
to the country through such tools as green bonds, green loans, green insurance, and green purchases. The fund provides financial support to promoting the transition to the principles of sustainable green development in various sectors of economy. Kazakhstan submitted a 280 million US dollar application. As of January 1, 2017, consolidated recoverable reserves of liquid hydrocarbons amounted to 785.8 million tonnes, while the increment of oil and gas condensate reserves in 2016 totalled at 7.2 million tonnes.

Based on previous research, we formulate the following hypothesis to be tested.

H4: There is a rational relationship between the assessment of the problems faced by the electric power industry and the choice of the electric power industry business model and improvement of the country's living standards within the framework of the proposed conceptual approach.

The third problem is the choice of the business model for the electric power industry operation in the market economy. The problem is very complicated, since modern electricity markets are fundamentally different from the classical markets of perfect competition. This can be explained by the organisational and technological features and technical regulations of the industry. There is insufficient amount of modern measuring and control devices on electricity markets allowing for real-time data exchange which is one of the necessary conditions for ensuring free competition.

At present, contradictions are aggravated by insufficient study of the fundamentals of improving the energy companies' competitiveness. Therefore, the problems of transforming the electric power industry's organisational structure become more relevant. Their solution can facilitate establishment of the mechanisms necessary for managing efficiently and developing strategies that would help evaluate and select priority problems faced by the electric power industry as a source of economic development and a factor of the country's future competitiveness.

The collapse of the USSR predetermined the development of the entire energy sector of Kazakhstan, including the electric power industry. In 1990, Kazakhstan only produced $83.7 \%$ of its electrical demand of 104.7 billion $\mathrm{kWh}$, with the 17.3 billion $\mathrm{kWh}$ balance deficit. In subsequent years, the generating capacities were expanded to add extra rated output of about 8 billion $\mathrm{kWh}^{1}$. The electric power industry of Kazakhstan is a basic sector of the economy awaiting structural and technological changes that will be accompanied by large-scale investments in the state's energy-efficient policy. The main problem of the electric power industry - high equipment deterioration - took shape during the financial crisis, with $65 \%$ of the electric power plant facilities aged over 20 years, and $31 \%$ over 30 years. $90 \%$ of the combined heat and power plant equipment is beyond the end of its useful life. The process of combining the disparate electric power systems of Kazakhstan's regions is currently underway to reduce electricity imports and increase exports and, thus, to optimise the structure of the generating capacities and to cut the cost of electric power generation.

Establishment of the electricity market rests upon the restoration of parallel operation of the electric power systems of Russia and Kazakhstan in order to fully cover the demand for cheap electricity and use the transit potential of the two countries more efficiently. The countries are currently creating interstate vertically integrated structures comprising the whole range of energy services. Reformation of Kazakhstan's electric power industry is intended to:

- create a transparent, verifiable, and efficient electric power supply system with a market price for electricity;

- promote more efficient electricity generation by cutting costs through competition among energy producers;

${ }^{1}$ The current state and prospects of the power industry development in Kazakhstan. Available at: https:// articlekz.com/article /6658. (in Russ.) 
- encourage the generating companies in the market to work with liquid payments and attract investments for their modernisation;

- improve electric power production efficiency through utilising market mechanisms that contribute to a reduction in electricity prices for the end users.

The main goal of the electric power industry reformation in Kazakhstan is to improve the efficiency of the enterprises within the industry, to create conditions for its development by encouraging investments, and to ensure reliable and uninterrupted electric power supply to consumers. In the course of the reform, the structure of the industry is shifting; the system of the state regulation of the industry is changing; the traditionally monopolistic (power transmission, operational dispatch management) and potentially competitive (power generation and sales, repair and service) functions are being separated; conditions for a competitive electricity market are emerging; and new companies are entering the market. However, deregulation of the electricity market does not mean that the state would completely waive its control over this segment of the economy.

Based on the research of the significant interrelations between the estimated problems faced by the electric power industry and the country's economic growth and competitiveness, the final hypothesis can be formulated as follows.

H5: The strategic importance of assessing the problems faced by the electric power industry development determines rational relationships of the conceptual approach in the field of energy efficiency, energy saving, environment, and market relations between energy producers and consumers ensuring economic growth and improvement of the living standards of the population.

\section{Conceptual approach to assessing priority problems}

The author's model for the empirical testing of the suggested hypotheses is shown in Fig. 2.

Based on the above analysis of working hypotheses, the authors propose a conceptual approach that represents the strategic pattern of the country's economic growth and competition following a timely solution of priority problems faced by the electric power industry in the framework of market relations as a system of dynamic normals:

$$
(G D P)^{\prime}>(P R)^{\prime}>(S)^{\prime}>(Q)^{\prime}>(\triangle C N)^{\prime}>(C N)^{\prime}>(C S)^{\prime}>(F)^{\prime}>\left(T_{e m}\right)^{\prime},\left(C_{2}\right)^{\prime} .
$$

The GDP growth rate and the growth rate of profit from the sale of electricity to consumers $(P R)^{\prime}$ take the first and the second place respectively. The growth rates of electricity sales $(S)^{\prime}$, and secondary energy use by consumers $(Q)$ ' rank the third. The fourth place is given to the growth rate of the savings of fuel and energy consumption among consumers $(\triangle C N)^{\prime}$ and the growth rate of fuel and energy consumption among electric power producers $(C N)^{\prime}$, which in turn is ahead of the growth rate of energy supply costs $(C S)^{\prime}$ followed by the growth rate of fuel supply $(F)^{\prime}$ to the country's electric power producers [Koksharov, 2015]. Finally, there is the growth rate of the total harmful emissions into the atmosphere of the country from fuel combustion at electric power facilities $\left(T_{e m}\right)^{\prime}$ and the growth rate of emissions $\mathrm{CO}_{2}-\left(\mathrm{CO}_{2}\right)^{\prime}$, which is possible if the required level of environmental safety and rational fuel consumption is ensured through current standards.

Such balance of the growth rates of the proposed indicators is known among scientists as a "decoupling effect" [Bobylev, Zakharov, 2011]. The "decoupling effect" refers to an economy where the GDP growth rate outruns that of the energy resource consumption. This effect is achieved in all developed countries of the world. For example, Denmark has doubled its GDP over the past three decades, while maintaining its energy consumption unchanged [Abboud, 2007]. The outperforming rates of energy saving and renewable energy consumption in 


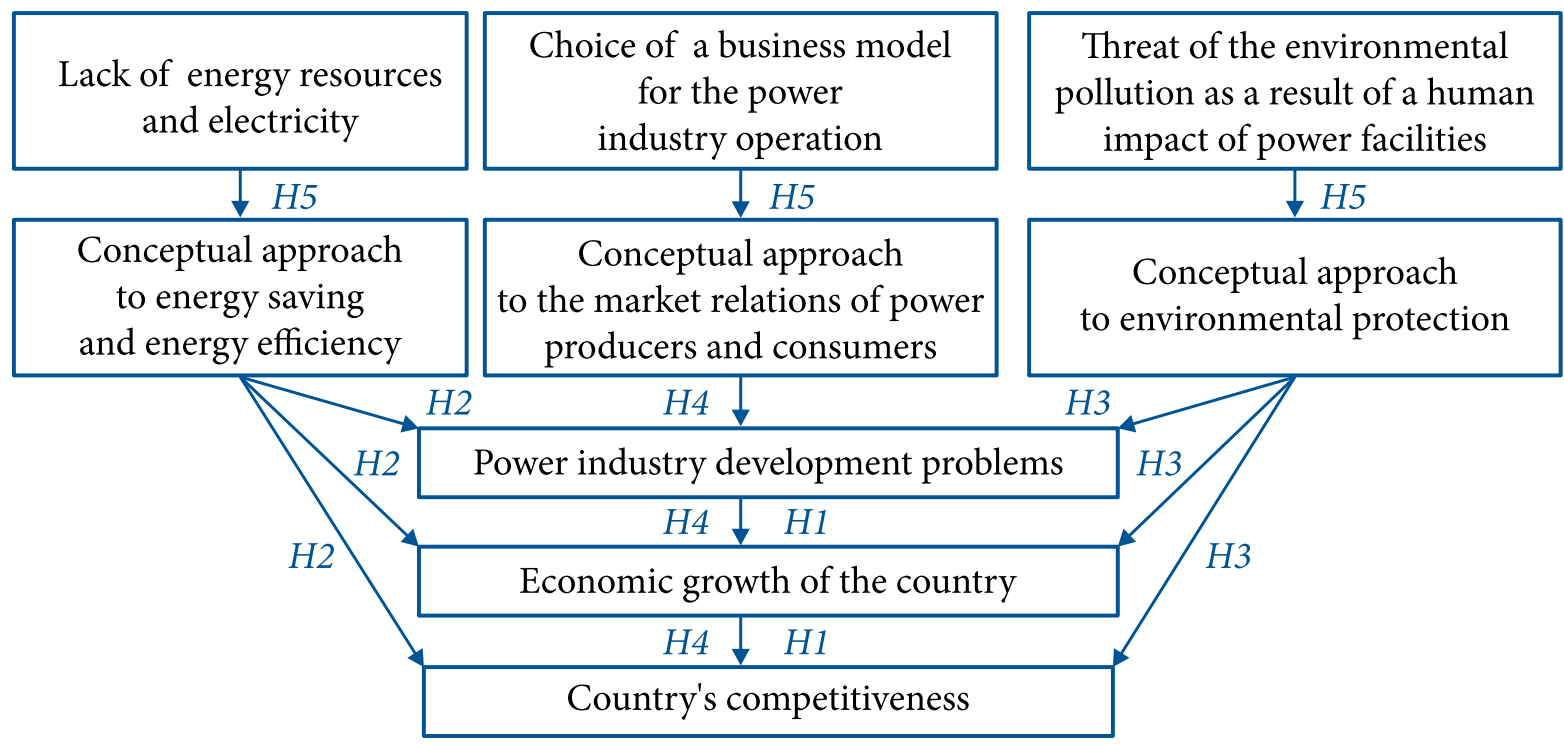

Fig. 2. The general theoretical model considering rational relationships between the problems faced by the electric power industry and the country's economic growth and competitiveness

Рис. 2. Общая теоретическая модель, учитывающая рациональную взаимосвязь проблем развития электроэнергетики с экономическим ростом и конкурентоспособностью страны

production processes are the factors that reduce the growth of total harmful emissions from fuel combustion $\mathrm{CO}_{2}$.

Assessment of the electric power industry strategic development using the dynamic normals is calculated by the equation:

$$
Q_{D}=1-\frac{n}{m}
$$

where $n$ is the number of indicators that changed their position in the actual sequence of growth rates as compared to the normal one; $m$ is the number of pairs of dynamic normal indicators or its derivatives.

The closer the assessment value is to unity, the more the electric power industry development strategy corresponds to the country's economic growth and competition within the framework of the proposed dynamic normals. The proposed conceptual approach is based on the systems approach that allows the electric power industry to be viewed as a system the operation of which is determined by the movement of resources and production waste represented by the ratio of dynamic normal. This allows the measures to be timely taken to eliminate the deficiencies in the electric power industry development.

Open market experience has led to realisation that competitive environment created in generation and sales sectors contributes to the self-regulation of production processes. At the same time, electricity will be priced within the framework of the market system. In order to monitor the problems of the electric power industry development, it is necessary to analyse dynamic normals and identify in a timely manner any negative trends in the strategic pattern of the country's economic growth and competitiveness.

For example, several irrational growth rate ratios characterising a number of problems faced by the country's electric power industry are presented in Table 1.

From Table 2 it can be seen that the "decoupling effect" is absent, since consumption growth rates are higher than those of Kazakhstan's GDP and development indicators of a number of leading sectors of the economy. 
Table 1. Formalised problems of the electric power industry development

Таблица 1. Формализованнье проблемы развития электроэнергетики

\begin{tabular}{|c|c|c|c|}
\hline \multicolumn{2}{|c|}{ Growth rate ratios } & \multirow{2}{*}{$\begin{array}{l}\text { Electric power industry } \\
\text { development problem }\end{array}$} & \multirow{2}{*}{ Impact of the unsolved problem } \\
\hline Rational & Irrational & & \\
\hline$(P R)^{\prime}>(\triangle C N)^{\prime}$ & $(P R)^{\prime}<(\Delta C N)^{\prime}$ & $\begin{array}{l}\text { Energy policy implemented with } \\
\text { no rational communication be- } \\
\text { tween producers and consumers }\end{array}$ & $\begin{array}{l}\text { Rise in tariffs and inconsistency } \\
\text { between energy saving and energy } \\
\text { consumption }\end{array}$ \\
\hline$(G D P)^{\prime}>(\Delta S)^{\prime}$ & $(G D P)^{\prime}<(\Delta S)^{\prime}$ & $\begin{array}{l}\text { No decoupling effect, the coun- } \\
\text { try's GDP growth and competi- } \\
\text { tiveness decline }\end{array}$ & $\begin{array}{l}\text { Electrical shortage and inefficient } \\
\text { structure of generating capacities, } \\
\text { low tax revenues, and rise in tariffs }\end{array}$ \\
\hline
\end{tabular}

Table 2. Indicators of the Republic of Kazakhstan's economic development in 2017-2021

Таблица 2. Показатели экономического развития Республики Казахстан на 2017-2021 гг.

\begin{tabular}{|l|c|c|c|c|c|c|}
\hline \multirow{2}{*}{ Indicator } & \multicolumn{3}{c|}{ Estimates } & \multicolumn{3}{c|}{ Forecast } \\
\cline { 2 - 8 } & 2016 & 2017 & 2018 & 2019 & 2020 & 2021 \\
\hline GDP, billion tenge & $44,354.0$ & $48,391.8$ & $51,690.6$ & $55,280.2$ & $59,611.2$ & $63,643.9$ \\
\hline Actual GDP growth, \% on the previous year & 100.5 & 101.9 & 102.1 & 102.7 & 102.9 & 103.1 \\
\hline $\begin{array}{l}\text { GDP, billion US dollars at the official } \\
\text { exchange rate }\end{array}$ & 123.2 & 134.4 & 143.6 & 153.6 & 170.3 & 187.2 \\
\hline GDP per capita, US dollars & $6,946.9$ & 7483.6 & $7,897.1$ & $8,348.3$ & $9,158.6$ & $9,962.0$ \\
\hline Industrial growth, \% on the previous year & 98.3 & 102.8 & 101.8 & 102.7 & 101.9 & 101.1 \\
\hline $\begin{array}{l}\text { Supply of electric power, gas, steam, } \\
\text { and air conditioning, \% on the previous year }\end{array}$ & 100.6 & 108.0 & 107.0 & 107.0 & 106.0 & 106.0 \\
\hline $\begin{array}{l}\text { Processing industry growth, } \\
\text { \% on the previous year }\end{array}$ & 100.0 & 101.2 & 102.0 & 103.0 & 102.2 & 102.2 \\
\hline
\end{tabular}

Note. Compiled using: Energy intensity of the processing industry in the Republic of Kazakhstan. Available at: http://comprom.miid. gov.kz/ru/pages/energoemkost-obrabatyvayushchey-promyshlennostirespubliki-kazahstan. (in Russ.)

The situation shown in Table 2 is caused by the following factors. The country's industry accounts for $30 \%$ of the total GDP and includes such energy-intensive industries as mining and non-ferrous metallurgy. Kazakhstan consumes 25-30 \% more fuel to produce one unit of energy than developed countries. The main reasons are deteriorated equipment and low efficiency of production processes. Electric power industry is accountable for more than $80 \%$ of the total greenhouse gas emissions.

\section{Conclusion}

The autors' model for evaluating the strategy for the electric power industry development based on the system of dynamic normals is comprehensive and can help identify emerging priority problems faced by the industry development and take measures to eliminate them in a timely manner.

The proposed conceptual approach to identifying priority problems in the electric power industry development is based on the working hypotheses that can be used to determine critical indicators for assessing the country's economic growth and competitiveness and, therefore, to make important management decisions at the level of economic sectors. Analysis of the present conditions for the industry development demonstrates the demand for the proposed integrated approach, which reflects the importance and complexity of the process of building market relations in the electric power industry. 


\section{References}

Barkin O. G., Volkova I. O., Kozhukhovskiy I. S., Kolesnik V. G., Kosygina A. V., Lazebnik A. I., Sorokin I. S., Yasin E. G. (2014). Russian power industry: Problems of choosing the model for development. Analytical report. XV Aprelskaya Mezhdunarodnaya nauchnaya konferentsiya po problemam razvitiya ekonomiki i obshchestva [15th Int. Sci. Conf. on the Problems of Economic and Social Development]. Moscow: Vysshaya shkola ekonomiki Publ. 45 p. (in Russ.)

Bobylev S. N. Zakharov V. M. (2011). Modernizatsiya ekonomiki i ustoychivoe razvitie [Modernisation of economy and sustainable development]. Moscow: Ekonomika Publ., 295 p. (in Russ.)

Germeyer Yu. B. (1971). Vvedenie $v$ teoriyu issledovaniya operatsiy [Introduction to the theory of operations research]. Moscow: Nauka Publ. 384 p. (in Russ.)

Volgin N. A., Kushlina V. I. (eds.) (2001). Gosudarstvennoe regulirovanie rynochnoy ekonomiki [State regulation of the market economy]. Moscow: Ekonomika Publ. 229 p. (in Russ.)

Dukenbaev K. D. (1998). Energetika Kazakhstana. Dvizhenie k rynku [Power industry of Kazakhstan. Transition towards the market]. Almaty: Galym Publ. 584 p. (in Russ.)

Klyuev Yu. B. (2018). Tseli i sredstva ekonomicheskogo razvitiya Rossii v kontekste perekhoda $\mathrm{k}$ shestomu tekhnologicheskomu ukladu [Goals and means of Russia's economic development under the sixth technological wave]. Izvestiya Uralskogo gosudarstvennogo ekonomicheskogo universiteta $=$ Journal of the Ural State University of Economics, vol. 19, no. 6, pp. 33-50. DOI: 10.29141/2073-1019-2018-19-6-3. (in Russ.)

Koksharov V. A. (2015). Upravlenie energopotrebleniem promyshlennogo predpriyatiya [Managing energy consumption of an industrial enterprise]. Ekaterinburg: UrGUPS Publ. (in Russ.)

Kornyakov V. (2000). Gosudarstvenno-korporativnoe napravlenie razvitoy ekonomiki [Statecorporate direction of economic development]. Ekonomist $=$ Economist, no. 5, pp. 74-80. (in Russ.)

Makarov A. A., Kononov Yu. D., Krivorutskiy L. D., Makarova A. S., Saneev B. G., Shapot D. V. (1984). Ierarkhiya modeley dlya upravleniya razvitiem energetiki $i$ metody soglasovaniya ikh resheniy [Hierarchy of models for managing energy development and methods for coordinating their decisions]. Irkutsk: SO AN SSSR Publ., Sibirskiy energeticheskiy institute Publ. (in Russ.)

Melentev L. A. (1982). Optimizatsiya razvitiya i upravleniya bol'shikh sistem energetiki [Optimisation of development and management of big power systems]. Moscow: Vysshaya shkola Publ. 319 p. (in Russ.)

Mirkin B. G. (1974). Problema gruppovogo vybora [The problem of collective choice]. Moscow: Nauka Publ. 256 p. (in Russ.)

Okorokov V. R. (1976). Upravlenie elektroenergeticheskimi sistemami. Tekhniko-ekonomicheskie printsipy $i$ metody [Management of electric power systems. Technical and economic principles and methods]. Leningrad: LGU Publ. 224 p. (in Russ.)

Padalko L. P. (1979). Kriterii i metody optimal'nogo upravleniya elektroenergeticheskoy sistemoy [Criteria and methods for optimal control of an electric power system]. Minsk: Nauka i tekhnika Publ. 198 p. (in Russ.)

Pfantsagl I. (1976). Teoriya izmereniy [Measurement theory]. Moscow: Mir Publ. 248 p. (in Russ.)

Rakitskiy Yu. V., Ustinov S. M., Chernorutskiy I. G. (1979). Chislennye metody resheniya zhestkikh sistem [Numerical methods for solving rigid systems]. Moscow: Nauka. 208 p. (in Russ.)

Revenkov A. (2001). Planirovanie v sisteme gosudarstvennogo reguliro-vaniya ekonomiki [Planning in the system of state regulation of economy]. Ekonomist $=$ Economist, no. 8, pp. 17-21. (in Russ.)

Suppes P., Zinnes Dzh. (1967). Osnovy teorii izmereniy. Psikhologicheskie izmereniya [Basic measurement theory. Psychological measurements]. Moscow: Mir Publ. (in Russ.)

Syroezhin I. M. (1980). Sovershenstvovanie sistemy pokazateley effektivnosti i kachestva [Improving the system of performance and quality indicators]. Moscow: Ekonomika Publ. 192 p. (in Russ.)

Tsisar I. F., Neyman V. G. (2002). Komp'yuternoe modelirovanie ekonomiki [Computer modelling of economics]. Moscow: Dialog-MIFI Publ. 224 p. (in Russ.)

Vaynzikher B. F. (ed.) (2008). Elektroenergetika Rossii 2030: Tselevoe videnie [Russian power industry 2030: Target vision]. Moscow: Al'pina Biznes Buks Publ. 352 p. (in Russ.) 
Abboud L. (2007). How Denmark paved the way to energy independence. Thirty-year plan uses wind, taxes, pig fat; consumers pay more. The Wall Street Journal, 16 April. Available at: https://www.wsj.com/ articles/SB117649781152169507.

Fraser P. (1999). Background report on regulatory reform in the electricity industry. Paris: OECD. 48 p.

Kendall M. G. (1955). Rank Correlation Methods. L.: Griffin and Co. 196 p.

\section{Information about the authors}

Vladimir A. Koksharov, Dr. Sc. (Econ.), Prof. of Transport Economics Dept., Ural State University of Railway Transport, 66 Kolmogorova St., Ekaterinburg, 620034, Russia

Phone: +7 (343) 221-24-41, e-mail: vakoksharov@mail.ru

Berik K. Dzhamanbalin, Postgraduate of Economic Security of Industrial Complexes Dept., Ural Federal University named after the first President of Russia Boris N. Yeltsin, 19 Mira St., Ekaterinburg, 620002, Russia

Phone: +7 (343) 375-41-27, e-mail: pkkstu@mail.ru
В. А. Кокшаров
Уральский государственный университет путей сообщения, г. Екатеринбург, Российская Федерация

Б. К. Джаманбалин Уральский федеральный университет имени первого Президента России Б. Н. Ельцина, г. Екатеринбург, Российская Федерация

\section{Стратегическая оценка развития электроэнергетики Казахстана}

Аннотация. Несмотря на стабильное состояние экономики Казахстана, необходимо объективно и всесторонне исследовать проблемы управления электроэнергетикой страны. Исследование направлено на выявление приоритетных проблем развития электроэнергетики Казахстана на основе стратегических оценок моделирования. Методология исследования представлена концепциями стратегического управления на макроуровне. Методы исследования основаны на процедуре многомерного ранжирования, что позволяет установить приоритеты развития отрасли в увязке с ключевыми целями страны. Методический подход к выявлению приоритетных проблем, направленный на повышение качества рассматриваемого этапа разработки стратегических планов отрасли, должен, во-первых, повысить объективность отбора главных проблем отрасли; во-вторых, максимально унифицировать и формализовать процедуру этого отбора, т. е. приспособить ее к использованию не только отрасли электроэнергетики, но и всех других крупных отраслей экономики. Предложена модель взаимосвязи развития электроэнергетики с экономическим ростом и конкурентоспособностью страны.

Ключевые слова: динамический норматив; конкурентоспособность; электропотребление; энергоемкость; энергосбережение; энергоэффективность. 
Для иитирования: Koksharov V. A., Dzhamanbalin B. K. Strategic assessment of electric power industry development: A case of Kazakhstan // Journal of New Economy. 2019. T. 20, № 4. C. 119-132. DOI: 10.29141/2073-1019-2019-20-4-7

Дата поступления: 26 февраля 2019 г.

\section{Источники}

Баркин О. Г., Волкова И. О., Кожуховский И. С., Колесник В. Г., Косыгина А. В., Лазебник А. И., Сорокин И. С., Ясин Е. Г. (2014). Электроэнергетика России: проблемы выбора модели развития: аналит. докл. к XV Апр. междунар. науч. конф. по проблемам развития экономики и общества. М.: Изд. дом Высшей школы экономики. 45 с.

Бобылев С. Н., Захаров В. М. (2011). Модернизация экономики и устойчивое развитие. М.: Экономика. 295 с.

Гермейер Ю. Б. (1971). Введение в теорию исследования операций. М.: Наука. 384 с.

Государственное регулирование рыночной экономики. (2001) / под ред. Н. А. Волгина, В. И. Кушлина. М.: Экономика. 229 с.

Дукенбаев К. Д. (1998). Энергетика Казахстана. Движение к рынку. Алматы: Галым. 584 с.

Клюев Ю. Б. (2018). Цели и средства экономического развития России в контексте перехода к шестому технологическому укладу // Известия уральского государственного экономического университета. Т. 19, № 6. С. 33-50. DOI:10.29141/2073-1019-2018-19-6-3

Кокшаров В. А. (2015). Управление энергопотреблением промышленного предприятия. Екатеринбург : УрГУПС.

Корняков В. (2000). Государственно-корпоративное направление развитой экономики // Экономист. № 5. С. 74-80.

Макаров А. А., Кононов Ю. Д., Криворуцкий Л. Д., Макарова А. С., Санеев Б. Г., Шапот Д. В. (1984). Иерархия моделей для управления развитием энергетики и методы согласования их решений. Иркутск: СО АН СССР, Сибирский энергетический институт.

Мелентьев Л. А. (1982). Оптимизация развития и управления больших систем энергетики. М.: Высшая школа. 319 с.

Миркин Б. Г. (1974). Проблема группового выбора. М.: Наука. 256 с.

Окороков В. Р. (1976). Управление электроэнергетическими системами. Технико-экономические принципы и методы. Л.: ЛГУ. 224 с.

Падалко Л. П. (1979). Критерии и методы оптимального управления электроэнергетической системой. Минск: Наука и техника. 198 с.

Пфанцагль И. (1976). Теория измерений. М.: Мир. 248 с.

Ракитский Ю. В., Устинов С. М., Черноруцкий И. Г. (1979). Численные методы решения жестких систем. М.: Наука. 208 с.

Ревенков А. (2001). Планирование в системе государственного регулирования экономики // Экономист. № 8. С. 17-21.

Суппес П., Зиннес Дж. (1967). Основы теории измерений. Психологические измерения. М.: Мир.

Сыроежин И. М. (1980). Совершенствование системы показателей эффективности и качества. М.: Экономика. 192 с.

Цисарь И. Ф., Нейман В. Г. (2002). Компьютерное моделирование экономики. М.: Диалог-МИФИ. 224 с.

Электроэнергетика России 2030: Целевое видение (2008) / под общ. ред. Б. Ф. Вайнзихера. М.: Альпина Бизнес Букс. 352 c.

Abboud L. (2007). How Denmark paved the way to energy independence. Thirty-year plan uses wind, taxes, pig fat; consumers pay more. The Wall Street Journal, 16 April. Available at: https://www.wsj.com/ articles/SB117649781152169507.

Fraser P. (1999). Background report on regulatory reform in the electricity industry. Paris: OECD. 48 p.

Kendall M. G. (1955). Rank Correlation Methods. L.: Griffin and Co. 196 p. 


\section{Информация об авторах}

Кокшаров Владимир Алексеевич, доктор экономических наук, профессор кафедры экономики транспорта Уральского государственного университета путей сообщения, 620034, РФ, г. Екатеринбург, ул. Колмогорова, 66

Контактный телефон: +7 (343) 221-24-41, e-mail: vakoksharov@mail.ru

Джаманбалин Берик Кадыргалиевич, аспирант кафедры экономической безопасности производственных комплексов Уральского федерального университета имени первого Президента России Б. Н. Ельцина, 620002, РФ, г. Екатеринбург, ул. Мира 19

Контактный телефон: +7 (343) 375-41-27, e-mail: pkkstu@mail.ru

(C) Koksharov V. A., Dzhamanbalin B. K., 2019 


\section{ТРЕБОВАНИЯ К МАТЕРИАЛАМ, ПРЕДСТАВЛЯЕМЫМ В ЖУРНАЛ «Journal of New Economy»}

Общие положения

Для публикации принимаются статьи, соответствующие тематике журнала и настоящим требованиям. Представляемые материалы должны быть актуальными, обладать научно-практической значимостью и новизной.

Статьи, направляемые в редакцию, рецензируются и в случае положительного заключения - редактируются. Редакция не согласовывает с авторами изменения и сокращения рукописи, не затрагивающие принципиальных вопросов.

Статья, отправленная автору на доработку, должна быть возвращена в исправленном виде в максимально короткие сроки с ответами автора на замечания рецензента, а также пояснениями всех изменений, сделанных автором.

Статьи аспирантов и соискателей могут приниматься к публикации без соавторства с доктором или кандидатом наук. Статьи, в число авторов которых входят студенты и магистранты, не принимаются к публикации.

Общее количество авторов статьи - не более трех (для международных коллективов - не более пяти).

Материалы, представляемые авторами в редакцию:

Материалы пересылаются в редакцию по электронной почте.

Заявка на публикацию включает следующие файлы:

1. Файл, озаглавленный фамилиями авторов на русском языке и содержащий:

1) 1-3 кода по классификации JEL;

2) сведения об авторах на русском языке*;

3) ключевые слова на русском языке (5-8 слов);

4) аннотацию на русском языке (150-200 слов);

5) название статьи на русском языке;

6) текст статьи;

7) библиографический список на русском языке.

2. Файл, озаглавленный фамилиями авторов на английском языке и содержащий:

1) перевод сведений об авторах на английский язык;

2) перевод названия статьи на английский язык;

3) перевод ключевых слов на английский язык;

4) перевод аннотации на английский язык;

5) перевод библиографического списка на английский язык.

* Фамилия, имя, отчество автора; ученая степень; ученое звание; должность; организация, которую представляет автор; адрес организации; контактный телефон (с указанием кода города); e-mail. Адрес организации указывается в последовательности: почтовый индекс, страна, город, улица, дом.

Вся указанная информация подлежит публикации.

Требования к оформлению рукописи

Объем статьи - от 35000 до 45000 знаков с пробелами.

Текст набирается через полтора интервала, кегль - 14 пт, гарнитура - Times New Roman на листе формата А4 с полями по 2 cм.

Все страницы рукописи нумеруются.

Каждая таблица должна иметь название, рисунки - подрисуночную подпись на русском и английском языках.

Уравнения, рисунки и таблицы нумеруются в порядке их упоминания в тексте.

Графические элементы (рисунки, схемы) должны быть рассчитаны на черно-белое воспроизведение и предоставлены в редактируемом виде. 


\section{Требования к списку источников}

Список должен преимущественно включать научные статьи в рецензируемых научных изданиях, монографии, авторефераты диссертаций. Нормативно-правовые документы, статистические материалы и материалы без указания фамилий авторов в список источников не включаются, при необходимости упоминаются в тексте статьи или выносятся в постраничную сноску.

Самоцитирование не должно превышать $10 \%$.

Список оформляется в алфавитном порядке: сначала русскоязычные, затем англоязычные источники. Источники в списке не нумеруются. Для идентификации источника в тексте используются фамилии авторов, год публикации. При наличии в описании источника электронного идентификатора DOI, он обязательно указывается в конце библиографического описания в списке источников.

Внутритекстовые ссылки на использованную литературу оформляются в квадратных скобках с указанием фамилии автора (ов), страницы. Опубликованный источник на кириллице цитируется - [Тамбовцев, 2017, с. 23], источник, использующий латиницу - [Buchanan, 2010, p. 37]. При одновременном цитировании нескольких источников, ссылка имеет вид [Тамбовцев, 2017, с. 23; Buchanan, 2010, p. 37]. Если количество авторов составляет от одного до трех, авторы перечисляются в ссылке через запятую, если больше - указывается [Тамбовцев и др., 2017, с. 23; Buchanan et al., 2010, p. 37]. Для различения авторов с одной фамилией применяются инициалы; для работ одного автора, опубликованных в одном году - латинская буквенная идентификация, например, [Тамбовцев, 2017a, 2017b]. Если фамилии цитируемых авторов выступают частью предложения, в квадратных скобках может указываться только год и страница: В. Л. Тамбовцев [2017, p. 23] отмечает, что ...

Рукописи, не соответствующие данным требованиям, возвращаются авторам.

Плата за публикацию статей не взимается.

Авторские гонорары редакцией не выплачиваются.

В случае принятия статьи к публикации авторы предоставляют заполненные заявки и экспертное заключение о возможности открытого опубликования.

\section{Прием статей:}

Уральский государственный экономический университет 620144, РФ, г. Екатеринбург, ул. 8 Марта/Народной Воли, 62/45, каб. 102А

Белоусова Елизавета Александровна

Телефон: +7 (343) 221-26-33

e-mail: journal@usue.ru 


\section{OOF RNAL}

Выпускается как продолжающееся научное издание с определенной периодичностью и следующими рубриками:

Теоретические основания экономического развития и роста Макроэкономический анализ и факторы экономического роста Трансформационные процессы в экономике Финансовые инструменты экономического роста Развитие денежно-кредитной системы Региональные аспекты экономического роста Развитие отраслевых рынков и предприятий

Адрес редакции: 620144, РФ, г. Екатеринбург, ул. 8 Марта/Народной Воли, 62/45 Контактный телефон: +7 (343) 221-26-33

Интернет-сайт: jne.usue.ru 


\title{
Journal of New Economy
}

\section{T. 20 , № 4}

2019

\author{
Ответственный редактор \\ С. В. Орехова \\ Редактор и корректор \\ Р. Д. Мочалова \\ Перевод статей \\ Д. А. Азаров \\ Информация на английском языке \\ Е.А. Белоусова \\ Компьютерная верстка \\ Е. Б. Александрова
}

Издатель: Уральский государственный экономический университет Адрес издателя: 620144, РФ, г. Екатеринбург, ул. 8 Марта / Народной Воли, 62 / 45

Подписано в печать 06.09.2019. Дата выхода в свет: 13.09.2019.

Формат $70 \times 100 / 8$. Уч.-изд. л. 11,9. Печ. л. 17,5. Усл. печ. л. 16,3.

Тираж 100 экз. Заказ 498.

Отпечатано с готового оригинал-макета

в подразделении оперативной полиграфии УрГЭУ

Адрес типографии: 620144, РФ, г. Екатеринбург, ул. 8 Марта / Народной Воли, 62 / 45 


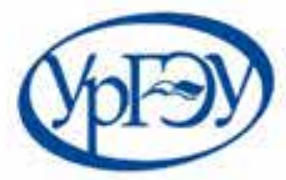

УРАЛЬСКИЙ ГОСУДАРСТВЕННЫЙ ЭКОНОМИЧЕСКИЙ УНИВЕРСИТЕТ

URAL STATE UNIVERSITY OF ECONOMICS

(1) ULRICHSWEB"

\section{ERIHPU్S}

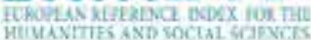

EBSCOhost

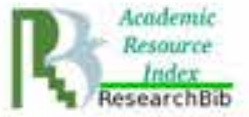

АУЧ НАЯ ЭЛЕKTPOHНA БИБAWOTERA

LIBRARY.RU

\section{CYBERLENINKA}

\section{Crossref}

Event Data
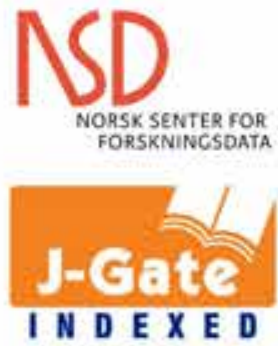

SSOAR 